Universidade de Brasília- UnB

Faculdade de Arquitetura e Urbanismo - FAU

Programa de Pesquisa e Pós-Graduação em Arquitetura e Urbanismo

TESE DE DOUTORADO

\title{
A contribuição dos elementos da forma urbana na construção da mobilidade Sustentável.
}

Caroline Duarte Alves Gentil

Orientadora: Professora Dr ${ }^{\mathrm{a}}$. Maria do Carmo de Lima Bezerra Co-orientador: Professor Dr. Valério Augusto Soares de Medeiros

Brasília, Abril de 2015. 
Universidade de Brasília- UnB

Faculdade de Arquitetura e Urbanismo - FAU

Programa de Pesquisa e Pós-Graduação em Arquitetura e Urbanismo

\title{
A contribuição dos elementos da forma urbana na construção da mobilidade Sustentável.
}

\author{
Caroline Duarte Alves Gentil
}

Tese de doutoramento apresentada como requisito parcial à obtenção do grau de Doutora pelo Programa de Pós-Graduação da Faculdade de Arquitetura e Urbanismo da Universidade de Brasília.

Orientadora: Professora Dr ${ }^{\mathrm{a}}$. Maria do Carmo de Lima Bezerra Co-orientador: Professor Dr. Valério Augusto Soares de Medeiros

Brasília, Abril de 2015. 


\section{FICHA CATALOGRÁFICA}

Ficha catalográfica elaborada automaticamente, com os dados fornecidos pelo(a) autor(a)

G338c

Gentil, Caroline Duarte Alves

A contribuição dos elementos da forma urbana na construção da mobilidade sustentável. / Caroline Duarte Alves Gentil; orientador Maria do Carmo de Lima Bezerra; co-orientador Valério Augusto Soares Medeiros. -- Brasilia, 2015. $172 \mathrm{p}$.

Tese (Doutorado - Doutorado em Arquitetura e Urbanismo) - - Universidade de Brasilia, 2015.

1. Mobilidade Urbana. 2. Forma Urbana. 3. Planejamento Urbano. I. Bezerra, Maria do Carmo de Lima, orient. II. Medeiros, Valério Augusto Soares, co-orient. III. Título. 


\section{TERMO DE APROVAÇÃO}

\section{A contribuição dos elementos da forma urbana na construção da mobilidade Sustentável.}

Autora: Caroline Duarte Alves Gentil

Tese de doutorado submetida à Faculdade de Arquitetura e Urbanismo da Universidade de Brasília UnB, como parte dos requisitos necessários a obtenção do Grau de Doutora em Arquitetura e Urbanismo, área de concentração "Ambiente, paisagem e sustentabilidade”.

Aprovado em: 06/04/2015

BANCA EXAMINADORA

Maria do Carmo de Lima Bezerra; PhD (FAU - UnB).

(ORIENTADORA)

Valério Augusto Soares Medeiros; PhD (FAU - UnB).

(CO-ORIENTADOR)

Erika Cristine Kneib; Dra. (FAU - UFG).

(EXAMINADORA EXTERNA)

Paulo Cesar Marques da Silva; PhD (ENC - UnB).

(EXAMINADOR EXTERNO)

Rômulo José da Costa Ribeiro; Dr. (FAU - UnB).

(EXAMINADOR INTERNO)

Otto Toledo Ribas; PhD (FAU - UnB).

(EXAMINADOR INTERNO)

Brasília, Abril de 2015. 
DEDICATÓRIA

Dedicado a ela: DIRCE, mãe desta vida. 


\section{AGRADECIMENTOS}

A Deus, o grande arquiteto do universo, que me permite viver esta vida e possibilita constantemente inúmeras conquistas.

Ao meu esposo Wanderlúbio Barbosa Gentil e meu filho Antônio Gentil Duarte, pela paciência e apoio durante toda trajetória para conclusão do doutorado.

As minhas cunhadas, Ivatônia que cedeu carinhosamente seu apartamento em Brasília; e Sônia, Kátia e Edlaine que em muitos momentos ajudaram-me enquanto estive em Brasília.

Ao meu grande inspirador pelos estudos Dr. Vicente Firmino Cambota (in memorian).

A minha orientadora Professora Maria de Carmo, por todo auxílio e acompanhamento dado durante a pesquisa.

Ao meu co-orientador Professor Valério, que aceitou auxiliar-me neste desafio, juntamente com minha orientadora.

Aos professores: Otto, Erika, Rômulo, Frederico Holanda e Paulo Cesar, que sempre se mostraram disponíveis para trocar ideias sobre o andamento da pesquisa.

Aos amigos Kátia, Frederico, André, Luciana, Gabriel e Yvete, por todo auxílio na execução de algumas tarefas e também pelos laços de amizade, que levarei para sempre comigo.

Ao Instituto Federal de Educação Ciência e Tecnologia - IFG, Campus Jataí, por proporcionar três anos de licença com bolsa para realização do doutorado.

Por fim, aos funcionários do PPG FAU e ao Professor Marcio Buzar que inicialmente me aceitou como sua orientanda no programa. 


\section{RESUMO}

\section{A contribuição dos elementos da forma urbana na construção da mobilidade sustentável.}

O trabalho discute e apresenta a contribuição que os elementos da forma urbana desempenham na construção da mobilidade sustentável. Parte do entendimento desenvolvido nesta pesquisa sugere que a mobilidade envolve tanto o estudo das diferentes modalidades de transporte e tipos de acesso às funções da cidade por meio da infraestrutura urbana, como também a relação entre estes aspectos e a forma urbana, em que, a consideração dos arranjos espaciais que conformam as cidades dispersa e compacta ganham destaque. As questões colocadas pela pesquisa podem ser resumidas da seguinte forma: tendo em vista as características das cidades compacta e dispersa, quais elementos definidores da forma urbana contribuem para a mobilidade sustentável? Como objetivar a discussão da mobilidade na tomada de decisão do planejamento urbano por meio de uma ferramenta espacial? Como resultado identificaram-se os elementos da forma urbana compacta à mobilidade urbana sustentável capazes de apoiar o projeto urbano como: alta densidade, menor fragmentação urbana, diversidade de usos do solo e característica do desenho urbano. Definidos esses elementos, a pesquisa apresenta como contribuição às decisões de planejamento urbano, o desenvolvimento de um Procedimento de Análise Espacial para a identificação de áreas urbanas que apresentam maior potencial para mobilidade sustentável. A metodologia de trabalho foi dividida em três fases distintas: i. Elaboração do referencial teórico e da revisão de literatura que permitiram extrair as variáveis de estudo relativas à forma urbana e a mobilidade urbana para embasar o desenvolvimento do Procedimento de Análise Espacial; ii. Desenvolvimento e aplicação de um Procedimento de Análise Espacial, em estudo de caso específico que contemplou o município de Goiânia-GO; e, por fim, iii. Aplicação do Procedimento de Análise Espacial na cidade de Goiânia que permitiu validar os elementos da forma urbana bem como o Procedimento de Análise Espacial definidos, possibilitando relacionar forma e mobilidade, uma vez que foram identificadas áreas com maior e menor potencial para mobilidade urbana sustentável. Conclui-se que os resultados obtidos se constituem em contribuição ao desenvolvimento de Planos Diretores Municipais que procurem utilizar elementos da forma urbana como indutores de um melhor potencial para mobilidade sustentável. 


\section{ABSTRACT \\ The contribution of urban form in the construction of sustainable mobility.}

This thesis discusses the contribution that urban form elements have in the construction of sustainable mobility. The understanding developed in this research suggests that the mobility involves both the study of different transport modalities and types of access to city functions through the urban infrastructure, as well as the relationship between these aspects and the urban form; wherein regarding spatial arrangements, which conforms the dispersed city and compact city, gain prominence. The issues placed by this research can be summarized in the following manner: considering that the characteristics of dispersed city and compact city, what are the elements that define urban form contribute to sustainable mobility? How do we aim the discussion of mobility in the decision making of urban planning using a special tool? As a result, we identified the compact urban form elements to sustainable urban mobility able to support the urban project, such as: high density, smaller urban fragmentation, land use diversity, and characteristics of urban design. Once we define these elements, the research shows as contributions to decisions of urban planning, the development of an Spatial Analysis Procedure to identify urban areas that show higher potential of sustainable mobility. The methodology of this work was divided in three distinct phases: i. Elaboration of theoretical background and bibliographic review that allow extracting the study variables relative to urban form and urban mobility to support the development of Spatial Analysis Procedure; ii. Development and application of a Spatial Analysis Procedure in a specific case study that contemplated the municipality of Goiânia-GO; and, finally, iii. Application of Spatial Analysis Procedure in Goiânia that allowed validating the urban form elements as well as the defined Spatial Analysis Procedure, allowing to relate form and mobility, once we have identified areas with higher and lower potential to sustainable urban mobility. We conclude that the results constitute contributions to development of Municipal Master Plans that seek to use urban form elements as inductors of a better sustainable mobility potential. 


\section{LISTA DE FIGURAS}

Figura 1: Estrutura metodológica da pesquisa, capítulos da tese e objetivos atendidos. 26

Figura 2: Distribuição de viagens por modal no Brasil. 30

Figura 3: Divisão modal por porte de município.. 31

Figura 4: Meio de Transporte mais utilizado por escolaridade (\%).. 32

Figura 5: (a) Consumo de energia por modo; (b) Emissão de poluentes por modo (CO2). 33

Figura 6: Relação entre forma urbana e tecnologia de transporte - cidades norte-americanas. 41

Figura 7: Três fases do processo de urbanização.. 43

Figura 8: Dimensões consideradas nos diferentes conceitos de sustentabilidade. 44

Figura 9: Padrões de Desenho Urbano que influenciam a densidade. 46

Figura 10: Relação entre consumo de combustível e densidade populacional..... 50

Figura 11: Vantagens e desvantagens de baixas e altas densidades. 51

Figura 12: Esquema da relação entre núcleos compactos/dispersos e a redução de deslocamento..... 56

Figura 13: Análise das variáveis da forma urbana e sua relação com a mobilidade sustentável: simplificação do problema.

Figura 14: Famílias de variáveis no eixo de análise I. ..... 68

Figura 15: Esquema básico: Análise de Risco 72

Figura 16: Esquema mostrando as etapas do método ARE. 74

Figura 17: Árvore de avaliação de grandezas da análise de risco. 75

Figura 18: Exemplo de matriz de combinação de indicadores de risco ecológico. 76

Figura 19: Articulação entre os eixos de análise 77

Figura 20: Esquema ilustrativo das etapas do Procedimento de Análise Espacial.. 79

Figura 21: Esquema mostrando a sobreposição das variáveis do estudo. 80

Figura 22: Valores médios de integração obtidos para as 44 cidades brasileiras. 90

Figura 23: Árvore de avaliação com os elementos da forma urbana.

Figura 24: Exemplo de um dos caminhos percorridos na Árvore de Avaliação da Forma Urbana e utilização da lógica matemática.

Figura 25: Eixo de Análise II - Elementos de Transporte e Circulação. 106

Figura 26: Exemplo de um dos caminhos percorridos na Árvore de Avaliação dos elementos de Transporte e Circulação e utilização da lógica matemática. 
Figura 27: Matriz de Avaliação. 108

Figura 28: Localização de Goiânia - Goiás. 112

Figura 29: Região Metropolitana de Goiânia - RMG. 113

Figura 30: Plano original de Goiânia proposto por Atílio Corrêa 1933. 115

Figura 31: Zoneamento proposto por Atílio Corrêa para Goiânia, 1933.. 116

Figura 32: Macrozona construída e Macrozona rural. 117

Figura 33: subdivisão macrozona construída. 118

Figura 34: Perímetro urbano e as sete regiões administrativas. Elaboração: Autora 121

Figura 35: Cartograma de Goiânia ilustrando a "Área Adensável” e a "Área de Desaceleração de Densidade", de acordo com PDG (2007).

Figura 36: Distribuição dos Vazios Urbanos em Goiânia. 128

Figura 37: Espacialização dos resultados para variável Integração Global. 129

Figura 38: Árvore de avaliação para agregação das variáveis dispostas no Eixo de Análise "Forma Urbana"..

Figura 39: Caminho percorrido na árvore de avaliação para R.A. Centro - Campinas. 132

Figura 40 : Mapa síntese da Forma Urbana. Espacialização dos resultados para todas as variáveis do Eixo de Análise I..

Figura 41: Rede de transporte público em Goiânia.

Figura 42: Distribuição dos pontos de ônibus em cada R.A..

Figura 43: Distribuição dos terminais nas R.A.

Figura 44: Árvore de avaliação para agregação das variáveis dispostas no Eixo de Análise "Transporte e Circulação".....

Figura 45: Caminho percorrido na árvore de avaliação para R.A. Centro - Campinas. 145

Figura 46: Mapa síntese da Forma Urbana. Espacialização dos resultados para todas as variáveis do Eixo de Análise I..

Figura 47: Matriz de Agregação para avaliar o Potencial de Mobilidade Sustentável. 148

Figura 48: Mapa Potencial Mobilidade Sustentável para Goiânia. 150 


\section{LISTA DE TABELAS}

Tabela 1: Avaliação da sustentabilidade da forma urbana. 49

Tabela 2: Indicadores revisados por Costa (2008). 65

Tabela 3: Escala de Avaliação para o indicador densidade urbana. 83

Tabela 4: Escala de avaliação do uso misto. 85

Tabela 5: Escala de avaliação para o indicador vazio urbano. 86

Tabela 6: Escala de avaliação para o indicador extensão da rede de transporte público. 96

Tabela 7: Escala de avaliação para o indicador acessibilidade ao transporte público. 99

Tabela 8: Escala de avaliação para o indicador vias para pedestre. 101

Tabela 9: Escala de avaliação para o indicador extensão e conectividade de ciclovias. 104

Tabela 10: Índice de dispersão 2000 e 2010

Tabela 11: Resultado para a variável densidade populacional urbana em Goiânia. 122

Tabela 12: Avaliação para o uso do solo urbano. 125

Tabela 13: Avaliação para a variável vazios urbanos em Goiânia. 126

Tabela 14: Avaliação para a variável desenho urbano - Integração Global para Goiânia. 129

Tabela 15 : Resumo da avaliação das variáveis para cada R.A em Goiânia. 132

Tabela 16: Avaliação para a variável E.R.T.P. para Goiânia. 136

Tabela 17: Avaliação para a variável A.T.P. em Goiânia. 138

Tabela 18: Avaliação para o indicador Vias para Pedestre para cada R.A. de Goiânia. 141

Tabela 19: Avaliação para o indicador ECC para cada R.A. em Goiânia. 142

Tabela 20: Resumo da avaliação das variáveis para cada R.A em Goiânia. 145

Tabela 21: Resultado "Potencial de Mobilidade Sustentável" para cada R.A em Goiânia. 149 


\section{LISTA DE QUADROS}

Quadro 1: Histórico da evolução conceitual sobre sustentabilidade em transportes.............................. 35

Quadro 2: Estratégias socioeconômicas e ambientais para auxiliar a mobilidade sustentável. ............. 36

Quadro 3: Fatores da forma urbana que podem afetar o comportamento de viagens. .......................... 52

Quadro 4: Principais argumentos a favor e contra a cidade compacta:............................................... 53

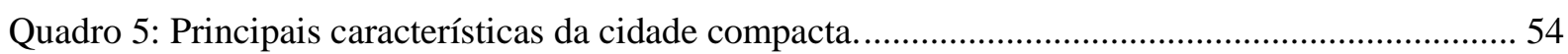

Quadro 6: Características e fatores que favorecem a dispersão. ........................................................ 57

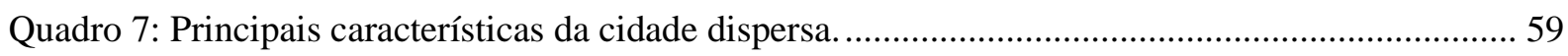

Quadro 8: Principais características da cidade compacta e dispersa de acordo com a revisão de

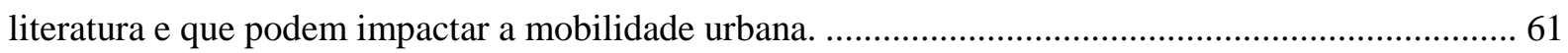

Quadro 9: Síntese dos fatores relacionados à forma urbana compacta e sua influência em padrões de

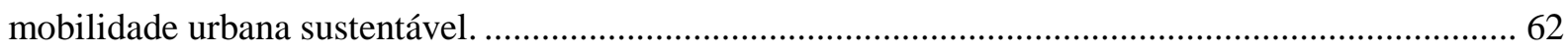

Quadro 10: Pesquisas Nacionais e Internacionais sobre Indicadores de Mobilidade Urbana............... 63

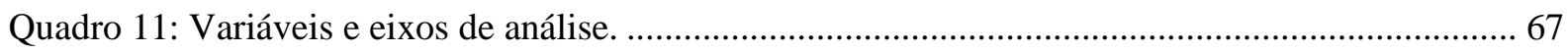

Quadro 12: Escala de avaliação para a variável densidade populacional em Goiânia........................ 122

Quadro 13: Escala de avaliação para a variável característica do uso do solo urbano......................... 125

Quadro 14: Escala de avaliação para a variável "Vazios Urbanos".................................................... 126

Quadro 15: Escala de avaliação para a variável desenho urbano - Integração Global......................... 128

Quadro 16: Escala de avaliação para a variável E.R.T.P. para Goiânia............................................. 135

Quadro 17: Escala de avaliação para a variável A.T.P. para Goiânia................................................ 138

Quadro 18: Escala de avaliação para o indicador Vias para Pedestres para Goiânia........................... 140

Quadro 19: Escala de avaliação para o indicador ECC para Goiânia................................................. 142 


\section{SUMÁRIO}

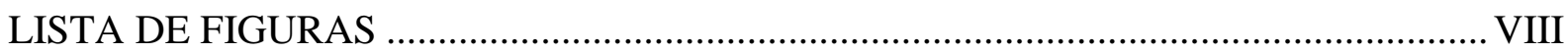

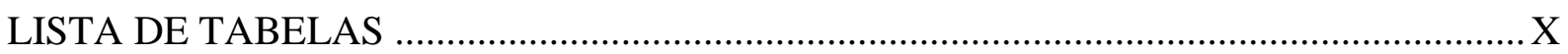

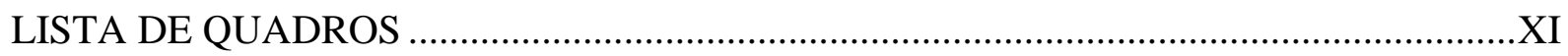

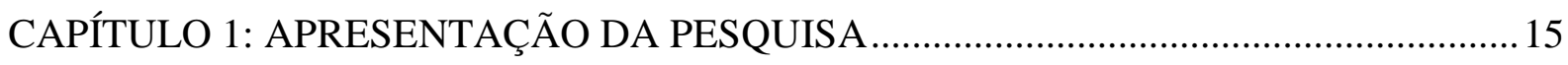

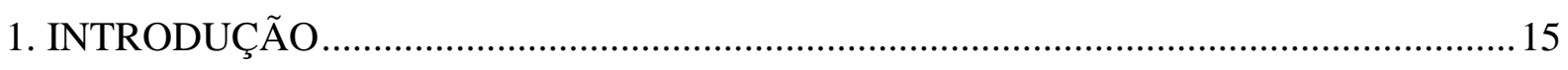

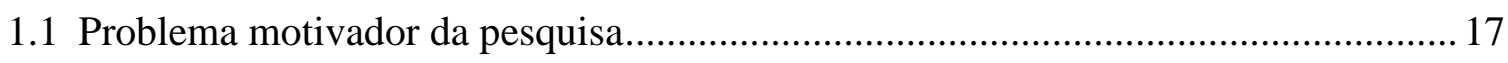

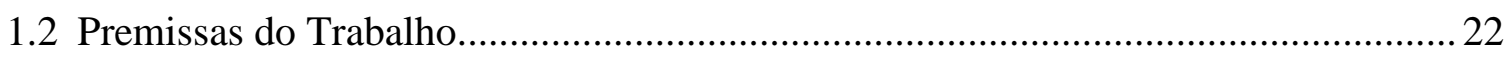

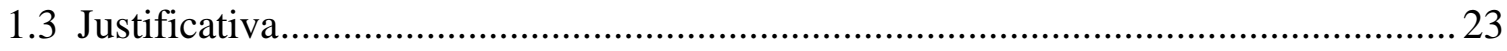

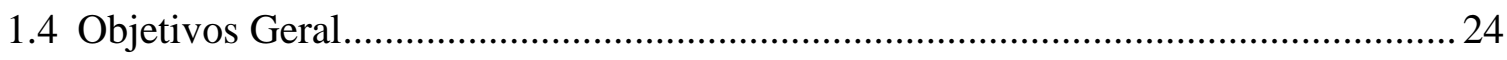

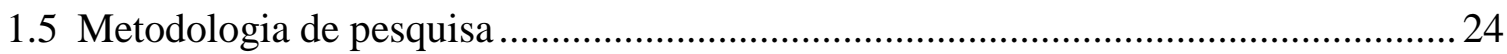

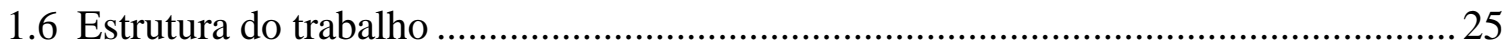

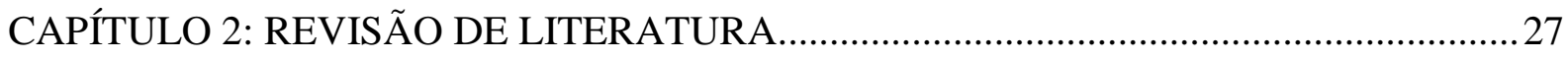

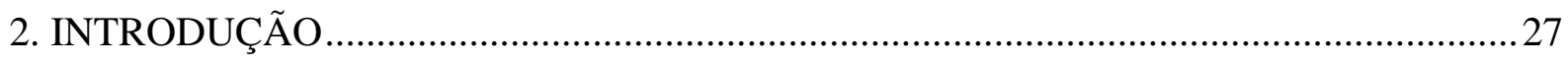

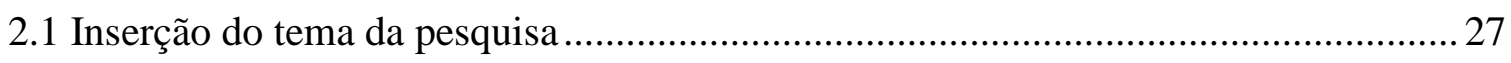

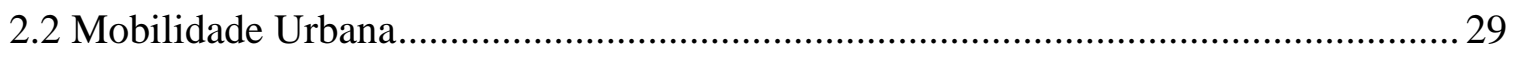

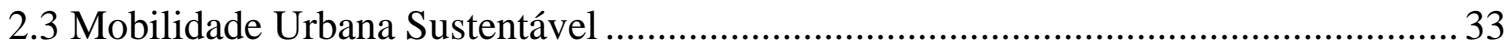

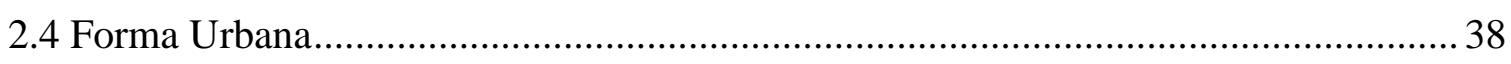

2.5 Conceitos e características da cidade compacta e cidade dispersa................................ 44

2.5.1 Cidade compacta ……………………………………………………………..... 44

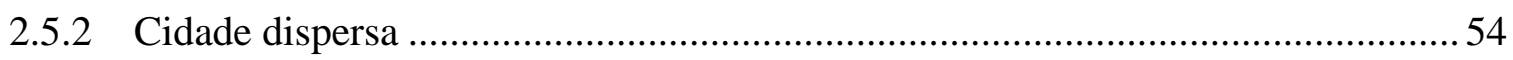

2.6 Atributos da forma urbana que podem potencializar a mobilidade urbana sustentável60

2.6.1 Indicadores de Mobilidade Urbana Sustentável.........................................................63

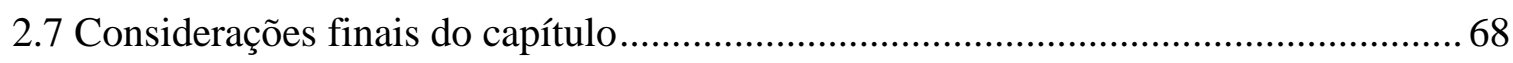

CAPÍTULO 3: ELABORAÇÃO DE PROCEDIMENTO DE ANÁLISE ESPACIAL.............70

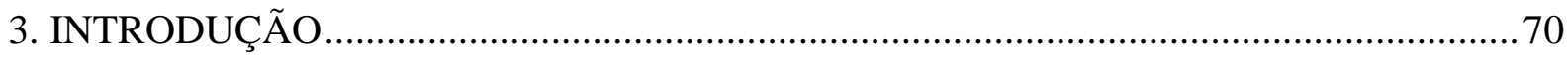

3.1 Desenvolvimento do Procedimento de Análise Espacial .............................................70

3.2 Aspectos conceituais, metodológicos e técnicos da Análise do Risco Ecológico. ......71

3.2.1 Aspectos conceituais ..............................................................................................

3.2.2 Aspectos metodológicos.................................................................................. 73 
3.2.3 Aspectos técnicos .76

3.3 Avaliação do potencial de mobilidade sustentável: Procedimento de Análise Espacial77

3.3.1 Etapas do Procedimento de Análise Espacial da mobilidade urbana .

3.3.1.1 Decomposição do sistema "Forma Urbana"

3.3.1.2 Agregação das variáveis do Eixo de Análise I - Árvore de Avaliação Forma Urbana 90

3.3.1.3 Decomposição do sistema "Transporte e Circulação" .93

3.3.1.4 Agregação das variáveis do Eixo de Análise II - Árvore de Avaliação 104

3.3.1.5 Combinação das árvores de avaliação: matriz potencial de mobilidade sustentável107

3.3.1.6 Proposição de medidas de controle 108

3.4 Considerações finais do capítulo 109

CAPÍTULO 4: ESTUDO DE CASO: ANÁLISE ESPACIAL DA MOBILIDADE NA

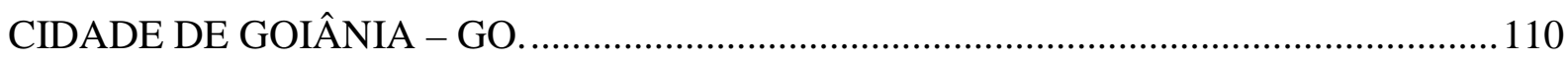

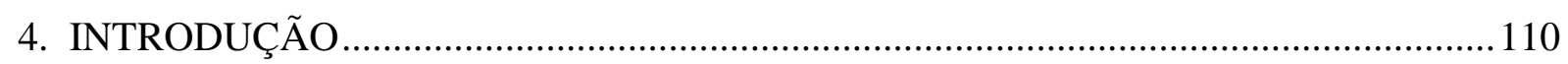

4.1 Contextualização geográfica da área objeto de estudo ............................................ 111

4.2 Histórico urbanístico de Goiânia: Planejamento Urbano........................................ 113

4.3 Goiânia: Plano Diretor e Mobilidade Urbana ............................................................. 116

4.4 Aplicação do Procedimento de Análise Espacial em Goiânia.................................. 120

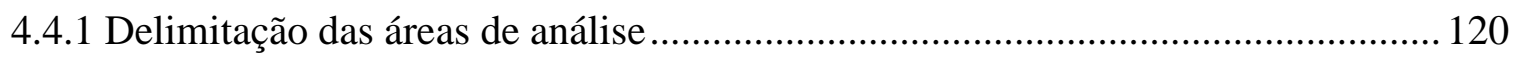

4.4.2 Eixo de análise I: Decomposição do sistema "Forma Urbana” ............................ 121

4.4.3 Agregação das variáveis do Eixo de Análise I - Árvore de Avaliação: Mapa Síntese

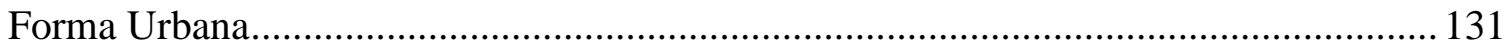

4.4.4 Eixo de análise II: Decomposição do sistema "Transporte e Circulação" .............. 135

4.4.5 Agregação das variáveis do Eixo de Análise II - Árvore de Avaliação: Mapa Síntese "Transporte e Circulação" ............................................................................... 144

4.4.6 Matriz de potencial de mobilidade: combinação dos eixos de análise I e II........... 148

4.4.7 Resultados: proposição de medidas de planejamento e desenho urbano. ............... 151

4.4.7.1 Propostas de integração entre os sistemas "Forma Urbana" e "Transporte e

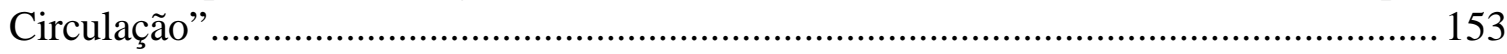

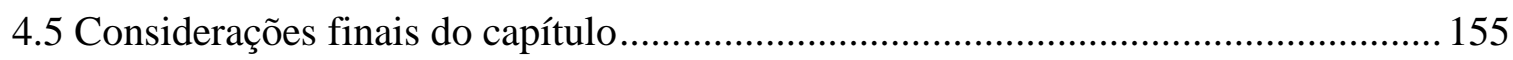


CAPÍTULO 5: RESULTADOS CONCLUSIVOS, POTENCIAL E LIMITAÇÕES DA

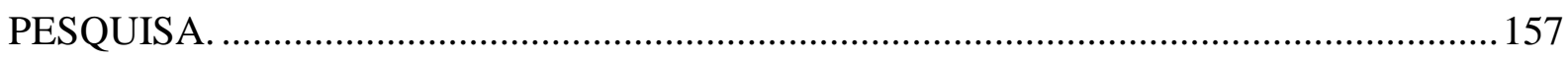

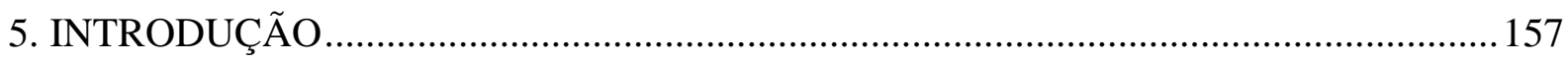

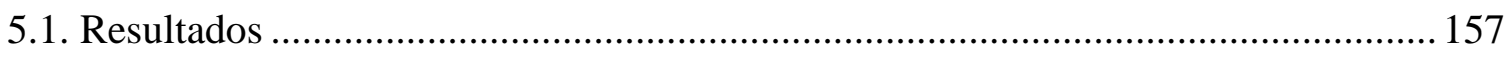

5.2. Potencialidades, limitações e recomendações........................................................ 159

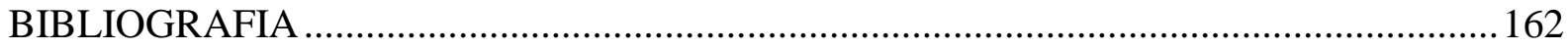

ANEXO A: Conjunto de indicadores sugeridos por Costa (2011) ................................... 170 


\section{CAPÍTULO 1: APRESENTAÇÃO DA PESQUISA}

\section{INTRODUÇÃO}

“O futuro é urbano.” (TULLOCH, 2014).

Esta pesquisa tem por intenção desenvolver um Procedimento de Análise Espacial para explorar o desempenho da forma urbana em relação à mobilidade urbana sustentável para o planejamento urbano. O estudo de caso é a cidade de Goiânia, analisada de acordo com um conjunto de variáveis oriundas da revisão de literatura.

A urbanização é uma tendência mundial, e esse fato tem causado profundas transformações socioambientais nas cidades. O crescimento urbano da população traduz-se em diferentes maneiras de uso e ocupação do solo que, em sua maioria, têm levado a estruturas urbanas com baixo desempenho em termos de mobilidade urbana.

A partir de uma leitura diacrônica Ascher (2010) destaca que "o crescimento das cidades esteve correlacionado, ao longo da história, com o desenvolvimento dos meios de transporte e armazenamento dos bens necessários para abastecer populações crescentes [...]”. Na Antiguidade, os deslocamentos eram feitos a pé ou em veículos com tração animal, produzindo um formato urbano mais compacto e misto. $\mathrm{O}$ advento do automóvel possibilitou que os assentamentos urbanos crescessem em todas as direções, favorecendo a dispersão. Com isso, pode-se assumir que as grandes cidades contemporâneas possuem formas complexas, influenciadas por fatores como distribuição de empregos, moradias, equipamentos públicos, entre outros, decorrentes de medidas relacionadas ao planejamento urbano e de transportes.

Ascher (2010) afirma também que as cidades mudaram de escala e forma, diluindo os limites entre urbano e rural. Paralelamente, a transformação do sistema urbano de mobilidade com a tecnologia de transporte modificou a localização das atividades, colocando em causa antigos sistemas de centralidade, multiplicando as polarizações. As cidades passam por um processo em que o desenvolvimento de novas tecnologias aumentou o leque de escolhas surgindo assim novas formas de segregação social e fragmentação espacial.

A necessidade de promover o desenvolvimento de estruturas urbanas tem incentivado pesquisas sobre novas formas de gestão e de planejamento que envolva as diferentes dimensões da cidade. A mobilidade urbana tem ocupado lugar de destaque entre os estudos, em função de seu papel sensível tanto no plano socioeconômico como ambiental. 
Existe um debate em torno do desenvolvimento urbano sustentável, centrado na busca da melhor forma urbana, em que se trabalha com a premissa de que diferentes formas produzem impactos distintos na sustentabilidade ambiental. A análise da literatura aponta que um dos parâmetros para atingir o padrão de cidades sustentáveis, principalmente no que diz respeito à mobilidade, seria adensá-las, torná-las compactas (ROGERS E GUMUCHDJIAN, 2001; LEITE E AWAD, 2012; OWENS, 1992; NEWMAN E KENWORTHY, 1989; RUEDA, 2002). No entanto, não existe um modelo universal e cada cidade possui características próprias que condicionam sua estrutura física, sejam em relação ao seu desenvolvimento socioeconômico ou especificidades de seu sítio, implicando usos e deslocamentos diferenciados e formas próprias.

Diante do exposto, esta tese procura investigar a relação existente entre forma urbana e mobilidade sustentável ${ }^{1}$, explorando os cenários situados entre os extremos da compactação e dispersão. É intenção elaborar um Procedimento de Análise Espacial da estrutura urbana que identifique elementos facilitadores da mobilidade urbana sustentável.

A forma urbana é considerada aqui como a expressão física dos espaços da cidade ou espaço urbano e sua estrutura espacial, ou a materialidade física da cidade. Por sua vez, os espaços da cidade podem ser revelados pelas áreas verdes e abertas e por meio dos índices urbanísticos (densidades, índice de ocupação, índice de aproveitamento, gabarito) previstos na legislação de ordenamento do território e pelo tipo de tecido urbano. Esses elementos caracterizadores da forma urbana levam a arranjos espaciais diferenciados.

A mobilidade urbana pode ser entendida como a facilidade de deslocamento de pessoas e bens no espaço urbano (MINISTÉRIO DAS CIDADES, 2005). No plano da sustentabilidade, deve considerar a redução do consumo de energia nos deslocamentos, o que implica políticas tanto no campo do planejamento de transporte segundo a integração modal (criando modos sustentáveis de deslocamentos como andar a pé ou de bicicleta e maior utilização do transporte público); quanto no campo do planejamento urbano vinculado a gestão do uso e ocupação do solo urbano.

Especificamente quanto à mobilidade sustentável, sabe-se que a mesma está estreitamente vinculada à forma urbana, pois as características da forma poderão influenciar

\footnotetext{
1 De acordo com Costa (2008) existem diferentes denominações para mobilidade sustentável. Entre as nomenclaturas utilizadas encontram-se as seguintes: transporte sustentável, transporte humano, mobilidade cidadã, mobilidade para todos, entre outros. No Brasil, o Ministério das Cidades trata do tema como mobilidade urbana sustentável e assim também será chamado nesta pesquisa.
} 
nos padrões de deslocamento, estimulando ou não a maior utilização de automóveis ou a opção por modos de transporte não-motorizados, o que expressa a contribuição da pesquisa para a análise das cidades no que diz respeito ao alcance da mobilidade sustentável.

Por fim, tem-se a compreensão de que obter mobilidade urbana sustentável depende não apenas dos elementos que compõem a forma urbana, como também do desempenho de uma série de variáveis relativas aos aspectos ambientais, sociais, econômicos, elementos de transporte e circulação, entre outros. Assume-se a investigação a partir dos elementos da forma urbana como instrumento indutor para mobilidade urbana sustentável. Outro viés explorado é a premissa de que a forma urbana compacta, tendo em conta seus atributos, pode colaborar no processo para atingir a mobilidade urbana sustentável, o que resulta do confronto da literatura explorada no Capítulo 2. Supõe-se que a interpretação das variáveis que relacionam forma urbana e mobilidade sustentável pode se converter em contribuição para o planejamento urbano e o desenho das cidades.

\subsection{Problema motivador da pesquisa}

O aumento do número de habitantes nas cidades acarretou uma descentralização econômica e espacial, movida pela alteração na escala das estruturas urbanas. À medida que as cidades foram crescendo, houve uma realocação das atividades de comércio e serviços, refletindo em um complexo sistema de circulação de pessoas e mercadorias.

Em função da concentração populacional e de um planejamento urbano desvinculado do planejamento de transportes, as mudanças e tendências das cidades modernas no Brasil têm apontado para um conjunto de desequilíbrios socioambientais. As principais consequências em relação à mobilidade urbana, advindas deste processo, são: poluição atmosférica e sonora, altos índices de acidentes, aumento no tempo e custo de viagens, maior utilização do transporte motorizado individual, dentre outros. Quanto à forma urbana, a fragmentação do tecido urbano revela-se como característica das grandes cidades brasileiras contemporâneas, que conduz a uma forma-espaço ${ }^{2}$ traduzida por grandes vazios e descontinuidade da rede viária conforme achados de Medeiros (2013).

$\mathrm{O}$ direito à cidade, segundo estabelecido no Estatuto da Cidade (Lei $\mathrm{n}^{\circ}$ 10.257) deve ser válido para todos; no entanto, o sistema econômico divide a sociedade em grupos com

\footnotetext{
${ }^{2} \mathrm{O}$ termo forma-espaço, se refere ao estudo de cheios (forma), vazios (espaço) e suas relações, no estudo da configuração urbana. É um termo utilizado por Holanda (2013), que deriva do conceito de Coutinho (1998) que, interpreta a arquitetura em seus componentes-meio (cheios, sólidos, maciços, invólucros: a forma) e componentes-fim (vão, vazios, ocos: o espaço) (HOLANDA, 2013; MEDEIROS, 2013).
} 
diferentes acessos ao espaço e aos serviços. A exclusão no meio urbano em função da renda é agravada devido às restrições impostas à movimentação, na forma de assentamentos habitacionais muitas vezes afastados por causa da dispersão e do preço da terra - o que reforça a perspectiva da segregação involuntária. A acessibilidade ou a facilidade de deslocamento convertem-se em um bem e, por isso, passam a ter um valor cada vez mais elevado na economia.

No Brasil, ou em países emergentes, grupos sociais menos favorecidos tendem a se instalar em áreas periféricas, provocando, desta forma, o aumento das distâncias e dos deslocamentos. O cenário, entre outros aspectos, é fruto de um espaço fragmentado, com ônus elevado em tempo e custo dos transportes (infraestrutura, manutenção, etc.); reduzindo a capacidade de deslocamento dos cidadãos (MEDEIROS E BARROS, 2011).

Para Gomide (2006), a divulgação de pesquisas a respeito das condições de mobilidade urbana demonstra uma total iniquidade, verificando que as pessoas mais atingidas são as de baixa renda. É esse estrato social que acaba sendo privado do acesso ao transporte público e que contribui para redução de oportunidades, impedindo o acesso aos serviços e equipamentos que a cidade oferece.

De acordo com Villaça (2001), as necessidades e condições de deslocamento, assim como a tecnologia de transporte, variam conforme as classes sociais: "as camadas populares são mais prisioneiras do espaço do que as camadas de mais alta renda". Significa que as camadas populares podem ter sua capacidade de mobilidade reduzida dependendo da política adotada nesse setor. Quando o Estado privilegia a construção de vias expressas, por exemplo, favorece as condições de deslocamento aos proprietários de automóveis. As ações que envolvem políticas de uso e ocupação do solo podem também aumentar ou restringir os deslocamentos.

Duarte et al. (2008) acreditam que o grande desafio que deve ser abraçado em prol de uma mobilidade urbana equitativa é a inclusão de parcelas consideráveis da população, proporcionando acesso amplo e democrático ao espaço urbano. A localização dos assentamentos e atividades urbanas é um dos principais fatores de desenvolvimento e orientação quanto ao crescimento das cidades, e, em razão disso, influenciam na mobilidade urbana.

As políticas em prol da mobilidade urbana no Brasil possuem suas origens na Constituição Federal de 1988 (Brasil, 1988), em que foi incorporado um capítulo sobre política urbana: Capítulo II, do Título VII, artigos 182 e 183. Porém as bases para o debate sobre política urbana encontraram forças no Estatuto da Cidade, publicado na forma da Lei 
Federal n 10.257 de 10 de julho de 2001 (Brasil, 2001), que regulamenta os artigos 182 e 183 da Constituição.

Com vista ao processo de tornar a mobilidade urbana possível de atender a todas as camadas sociais, o Estatuto da Cidade propõe uma revisão dos planos diretores, para que se criem políticas públicas que tornem o transporte coletivo e os meios de transporte nãomotorizados mais atrativos. Além disso, estabelece pelo artigo 41 a obrigatoriedade de existência de um Plano de Transporte Integrado para as cidades com mais de 500 mil habitantes que deve fazer parte do plano diretor do município ou ser compatível com o mesmo. No entanto, o documento não foi suficiente para orientar as questões de mobilidade urbana, tampouco no que diz respeito ao processo de torná-la mais sustentável, pois se limitou a exigir apenas um plano de transporte.

A preocupação com a crise da mobilidade urbana, principalmente em áreas metropolitanas, levou à elaboração da Lei ${ }^{\circ}$ 12.587, sancionada em 3 de janeiro de 2012 (Brasil, 2012), e que trata especificamente das diretrizes da Política Nacional de Mobilidade Urbana. Esta Lei possui embasamento no artigo 182 da Constituição Federal (Brasil, 1988) que dispõe sobre a política de desenvolvimento urbano, executada pelo Poder Público municipal, conforme diretrizes gerais fixadas em lei e tem por objetivo ordenar o pleno desenvolvimento das funções sociais da cidade e garantir o bem-estar de seus habitantes; o Plano Diretor é o instrumento básico desta política urbana. As propostas sobre as quais se desenvolveu a articulação nacional da lei de mobilidade são, em termos gerais: tornar o transporte público eficiente e acessível; diminuir as "externalidades negativas" do uso do automóvel (congestionamento e poluição) e responder à carência de investimentos e fontes de financiamento no setor e à fragilidade da gestão pública nos municípios. É possível observar que essa nova lei contempla em suas diretrizes gerais aspectos que podem influenciar um processo de mobilidade urbana sustentável, porém ainda com pouca atenção à forma da cidade - que parece contribuir para o problema.

Sobre o tema, no que diz respeito à forma da cidade ou forma urbana, é importante compreender, segundo Medeiros (2006) "que a cidade deve ser interpretada como um sistema relacional de interdependência, onde alterações em partes causam, em maior ou menor grau, alterações no todo”. Assim, a leitura da forma da cidade pode ser feita considerando vários atributos, como os aspectos quantitativos que são utilizados para controlar os atributos físicos: índices urbanísticos (taxa de ocupação, índice de aproveitamento, gabaritos e densidade); aspectos de organização funcional: uso e ocupação do solo; configuração da malha viária que pode apresentar propriedades capazes de promover ou restringir o 
movimento. Tratar da mobilidade urbana para que se alcancem patamares de sustentabilidade requer um olhar para esse conjunto de atributos que irão moldar a cidade e que devem ser orientados nas leis de zoneamento previstas nos planos diretores dos municípios.

Para investigar a relação entre forma urbana e mobilidade sustentável, trabalha-se, nesta pesquisa, com a teoria em torno da cidade compacta e dispersa ou forma urbana compacta e dispersa. A forma compacta era o modelo recorrente das cidades do passado, enquanto local de aglomeração urbana, com principal objetivo de proteção e defesa. Com a urbanização, ficou impossível conter o crescimento dessas estruturas. Os parâmetros advindos da forma compacta estão relacionados à alta densidade, mistura de usos do solo (lazer, serviços e emprego), mancha urbana menor e, portanto, maior utilização de espaço físico. Para Leite e Awad (2012), ao se promoverem territórios compactos com densidades qualificadas, uso misto do solo e multicentralidade, é possível reduzir a intensidade de viagens, estabelecer maior eficiência nos transportes públicos e encorajar o deslocamento por caminhadas ou ciclismo, elementos básicos para uma cidade sustentável.

A cidade dispersa contemporânea nasceu como resposta à urbanização insalubre desenvolvida no século XIX, a partir da Revolução Industrial, e vincula-se à teoria das “cidades jardins”, proposta por Ebenezer Howard (1902). A Carta de Atenas, síntese do pensamento modernista e base para a concepção de Brasília já em meados do século XX, surge como uma solução para os problemas da sociedade industrial do século $\mathrm{XX}$, propondo uma organização espacial focada no zoneamento rígido que primava pela separação de funções somada à malha urbana espraiada, elegendo o veículo como principal meio de locomoção no tecido urbano e gerando maior uso dos transportes automotores para o grande número de deslocamentos casa-trabalho e casa-lazer. O carro particular, simbolicamente, representava a perspectiva de futuro/progresso. A cidade resultante, caracterizada pelo urbanismo disperso, exerce maior pressão sobre recursos naturais com agravamento de problemas ambientais face ao espalhamento da cidade, exigindo um uso intenso de transporte para pessoas e bens, com aumento das emissões de gases de efeito estufa.

Em meados de 1950 começam a surgir críticas ao planejamento modernista, Jacobs (1961), por exemplo, propõem que os planejadores reconsiderem a habitação unifamiliar, os bairros dependentes de carros e centros comerciais segregados, que nesta época havia se tornado o modelo de planejamento e desenho urbano. Com essa preocupação, no final do século XX surge nos Estados Unidos o conceito do novo urbanismo em resposta ao “espraiamento ou suburbanização americana”. De acordo com Macedo (2007) o novo urbanismo "tem atenção para o equilíbrio necessário entre as construções, para atender as 
necessidades humanas e o ambiente natural, para a preservação do patrimônio histórico, e para a participação da comunidade e gestão sobre os espaços dos bairros." O novo urbanismo é um movimento voltado para o desenho urbano modelo baseado em um eficiente sistema de transporte público que conecta núcleos adensados em rede, promovendo um desenho urbano de uso misto que encoraja a caminhada e o ciclismo, trazendo como princípios a sustentabilidade e qualidade de vida.

O estudo da relação entre forma urbana e transporte urbano ou mobilidade urbana ${ }^{3}$ começou a ganhar força em torno da discussão sobre a possibilidade da cidade compacta oferecer melhores condições para o desenvolvimento sustentável das cidades. De acordo com Sepe e Gomes (2008), no início da década de 1990, a Comissão Europeia editou o Livro Verde do Ambiente Urbano, que apresentou como proposta o modelo de cidade compacta para implementar as políticas públicas nas cidades europeias. A ideia fundamental era a contenção do crescimento urbano horizontal, redução da impermeabilização do solo e das distâncias a serem percorridas associadas à oferta de transporte urbano, procurando deste modo minimizar os efeitos da urbanização em áreas ainda não urbanas.

As vantagens de uma cidade possuir atributos que a tornem mais compacta é um tópico que vem sendo debatido no campo do planejamento urbano e transportes. Existem alguns trabalhos publicados que tratam da forma urbana ideal ou sustentável como sendo aquela compacta (NEWMAN E KENWORTHY, 1989; BURTON, 2000). Porém, de acordo com Fernandes, Maia e Ferraz (2008), ainda são poucos os estudos que relacionam forma urbana e mobilidade sustentável e no debate da forma ideal pode-se concluir que não há um consenso entre os pesquisadores.

A cidade compacta não é vista por todos como a solução dos problemas ambientais urbanos. Cunha e Bochet (2003) referem-se à necessidade de maiores comprovações por meio de indicadores e avaliações, destacando que os argumentos a favor da densificação ainda são controversos e citam várias razões para isso: ausência de clareza na definição dos conceitos, incapacidade de definir indicadores precisos, falta de informações comparáveis, métodos de avaliação ainda pouco confiáveis.

Crane (1999), por exemplo, acredita que a imposição de mudanças no desenho urbano, articulada com o uso do solo, pode reduzir o uso do carro e evitar o espraiamento urbano. No

\footnotetext{
3 O termo mobilidade urbana, segundo a pesquisadora Costa (2008) e trabalhos publicados pelo Ministério das Cidades, (Ministério das Cidades, 2006), é usado também como sinônimo de transporte urbano.
} 
entanto, ressalta que a realidade da cidade é muito mais complexa do que o simples debate se a forma ideal das cidades é a compacta ou a dispersa.

Alguns trabalhos tentaram explicar a relação forma e mobilidade. Cervero e Kockelman (1997), por exemplo, elencam três dimensões das cidades que podem influenciar nos deslocamentos: densidade, diversidade e design (desenho urbano) - 3Ds e testam essa proposição examinando como os 3Ds afetam a taxa de viagem com foco na matriz origem/destino. Para os autores, o meio construído da cidade é em função da densidade de ocupação, da diversidade de usos e do desenho impresso pelo homem na cidade. Pouyanne (2005) também descreve em seu artigo Land Use Mix and Daily Mobility: The Case of Bordeaux que a interação forma e mobilidade passa por aspectos quantitativos da forma urbana - densidade e qualitativos - diversidade de uso da terra. A ideia que se trabalha é que a mistura de uso aproxima origem e destino das viagens, produzindo impactos positivos sobre a mobilidade.

Diante do problema exposto a respeito da avaliação das formas compactas e dispersas, verifica-se a necessidade de uma abordagem que possibilite identificar os elementos relacionados à forma urbana que influenciam a mobilidade urbana sustentável, focados no planejamento urbano e que possam ser utilizados na elaboração dos planos urbanos municipais. Pensando nessa lacuna, desenvolve-se uma investigação que analisa as características da forma urbana compacta e dispersa frente ao desempenho da mobilidade urbana sustentável. Em meio aos problemas levantados, este trabalho espera responder às seguintes questões de pesquisa:

i. A forma urbana traduzida no modelo de cidade compacta ou cidade dispersa pode influenciar os padrões de mobilidade urbana sustentável?

ii. Que elementos relativos à forma urbana e mobilidade urbana podem auxiliar para que se possa estabelecer um conjunto de variáveis relevantes para a criação de diretrizes que auxiliem no processo de planejamento urbano?

\subsection{Premissas do Trabalho}

Em função do que foi exposto tem-se como principal motivação para o desenvolvimento desta tese, a premissa de que as características associadas à forma urbana também são fundamentais para promover a mobilidade urbana sustentável, assim como os elementos de transporte e circulação. Assume-se que a forma urbana influencia os deslocamentos das pessoas, afetando diretamente a mobilidade urbana. 
Em função disso, serão explorados nesta tese os aspectos conceituais da forma urbana compacta e dispersa. Pretende-se estabelecer uma base conceitual em que seja possível extrair variáveis que possam ser utilizadas na elaboração de um Procedimento de Análise Espacial para relacionar Forma Urbana e Mobilidade Urbana e verificar o potencial de Mobilidade Sustentável. Importa destacar que, conforme debatido no item 1.1, há um entendimento de que os parâmetros advindos da forma compacta podem colaborar para o processo de mobilidade urbana sustentável e, portanto, levar à cidade sustentável, ao contrário do formato urbano disperso.

\subsection{Justificativa}

Parte das pesquisas na área de transportes (Shafer e Victor, 2000; Wu, Florian e Marcotte, 1994; Marin e Jamillo, 2009; Shafer, 1998), tende a interpretar a realidade da cidade de forma isolada, independente, considerando apenas os aspectos de transporte, e circulação. Há pouca ênfase nos atributos da forma urbana como meio para se atingir cenários mais satisfatórios para mobilidade urbana sustentável, em uma escala de análise macro 4 . Reforça-se o caráter de ineditismo desta pesquisa, uma vez que se entende que não há estudos que abordem a relação forma urbana e mobilidade urbana com ênfase no espaço.

Nesse sentido, este trabalho é relevante e justifica-se por tratar de um tema atual: a forma das cidades como atributo importante no processo de tornar a mobilidade sustentável, já que a forma das cidades brasileiras tem sido reflexo de ações pautadas no espalhamento sem controle de uso e ocupação do solo e total desarticulação da malha viária, gerando efeitos negativos sobre a mobilidade urbana. Além disso, optou-se por explorar as características da cidade compacta para verificar as possibilidades que esse modelo urbano pode oferecer, auxiliando no processo de transformação para uma cidade mais sustentável, podendo revelar aspectos ainda poucos explorados.

Analisar as relações entre forma e mobilidade torna-se de suma importância para identificar os elementos morfológicos que favorecem a mobilidade sustentável com vistas aos

\footnotetext{
${ }^{4}$ De acordo com Romero (2009), é importante definir a escala de análise para que se possa gerar recomendações específicas para sustentabilidade das cidades, oferecendo a possibilidade de ações concretas no espaço. A escala macro, segundo a pesquisadora, corresponde à escala das grandes estruturas ou escala da cidade e constitui a natureza da trama urbana, seus cheios e vazios, a massa edificada, os espaços que permeiam, a diversidade de alturas, o grau de fragmentação, qualidade perceptiva da grande forma física e organizacional, a variedade ambiental, o macro sistema de transporte e a permanência e a continuidade do construído.
} 
processos de planejamento urbano. Para tal, as justificativas que procuram descrever essa importância, são as seguintes:

i. As pesquisas existentes são, em sua maioria, derivadas dos estudos do planejamento de transportes que tendem a ver a cidade a partir do sistema de transporte e não como um sistema de múltiplas funções/dimensões/aspectos. De modo que a mobilidade está quase sempre associada aos elementos de transporte e circulação, não havendo ênfase nos elementos da forma urbana;

ii. Os estudos metodológicos que procuram relacionar diferentes aspectos envolvidos com a mobilidade o fazem de forma extensiva, igualando aspectos operacionais, gerenciais, locacionais, etc., sem hierarquizá-los ou estabelecer relações causais entre estes e a obtenção da mobilidade;

iii. Os estudos associando os elementos da forma urbana compacta com a mobilidade urbana sustentável; ainda são discursivos e pouco práticos para influenciarem no processo de planejamento urbano.

\subsection{Objetivos Geral}

A considerar o que foi argumentado na justificativa e problemática desta pesquisa a respeito de não estarem disponíveis métodos para estabelecer uma relação entre forma urbana e mobilidade urbana sustentável, tem-se por objetivo geral da pesquisa: desenvolver um Procedimento de Análise Espacial para explorar o desempenho da forma urbana em relação à mobilidade urbana sustentável para o planejamento urbano.

\subsection{Metodologia de pesquisa}

Como metodologia de pesquisa, foram estabelecidas três fases distintas e os objetivos específicos que deverão ser alcançados em cada fase:

i. Elaboração do referencial teórico e revisão de literatura: Construir um Procedimento de Análise Espacial que permita relacionar as variáveis da forma urbana com as de mobilidade urbana (denominadas variáveis de transporte e circulação), indicando as áreas com maior potencial para a mobilidade urbana sustentável;

ii. Desenvolvimento e aplicação do método: Aplicar o Procedimento de Análise Espacial numa estrutura urbana, de modo que suas análises fundamentem cenários em que os elementos da forma urbana potencializem mobilidade e se constituam em procedimento a ser 
utilizado em processo de planejamento urbano. Numa perspectiva ampliada, a intenção é fornecer subsídios para elaboração de planos diretores municipais comprometidos com a mobilidade urbana;

iii. Elaboração de análises complementares: Analisar o Procedimento de Análise Espacial frente aos resultados alcançados.

A Figura 1 que consta no item 1.6 ilustra as etapas estabelecidas na metodologia de pesquisa, os capítulos da tese e os objetivos atendidos em cada etapa.

\subsection{Estrutura do trabalho}

Esta tese estrutura-se em cinco capítulos. Após este capítulo 1, que contém a introdução e apresentação do tema de pesquisa, seguem as demais partes conforme descritas abaixo:

Capítulo 2 - Fundamentação teórica: aqui constam as discussões sobre os conceitos da forma urbana, cidade compacta, cidade dispersa, cidade sustentável, mobilidade urbana, mobilidade urbana sustentável, indicadores de mobilidade urbana sustentável, entre outros. O produto é a relação entre forma urbana e mobilidade urbana, fornecendo o lastro para as variáveis que serão utilizadas na elaboração do procedimento de análise;

Capítulo 3 - Procedimento de Análise: descrição e desenvolvimento do Procedimento de Análise Espacial e suas etapas;

Capítulo 4 - Aplicação do Procedimento de Análise Espacial: descrição do estudo de caso (Goiânia - GO) e aplicação do procedimento de análise;

Capítulo 5 - Análise complementar e conclusões: análise do Procedimento de Análise Espacial frente aos resultados alcançados, demonstrando suas potencialidades e limitações. Respostas às questões de pesquisa, validação da hipótese, os desafios e limitações enfrentados no transcorrer do estudo e as sugestões para trabalhos futuros. 


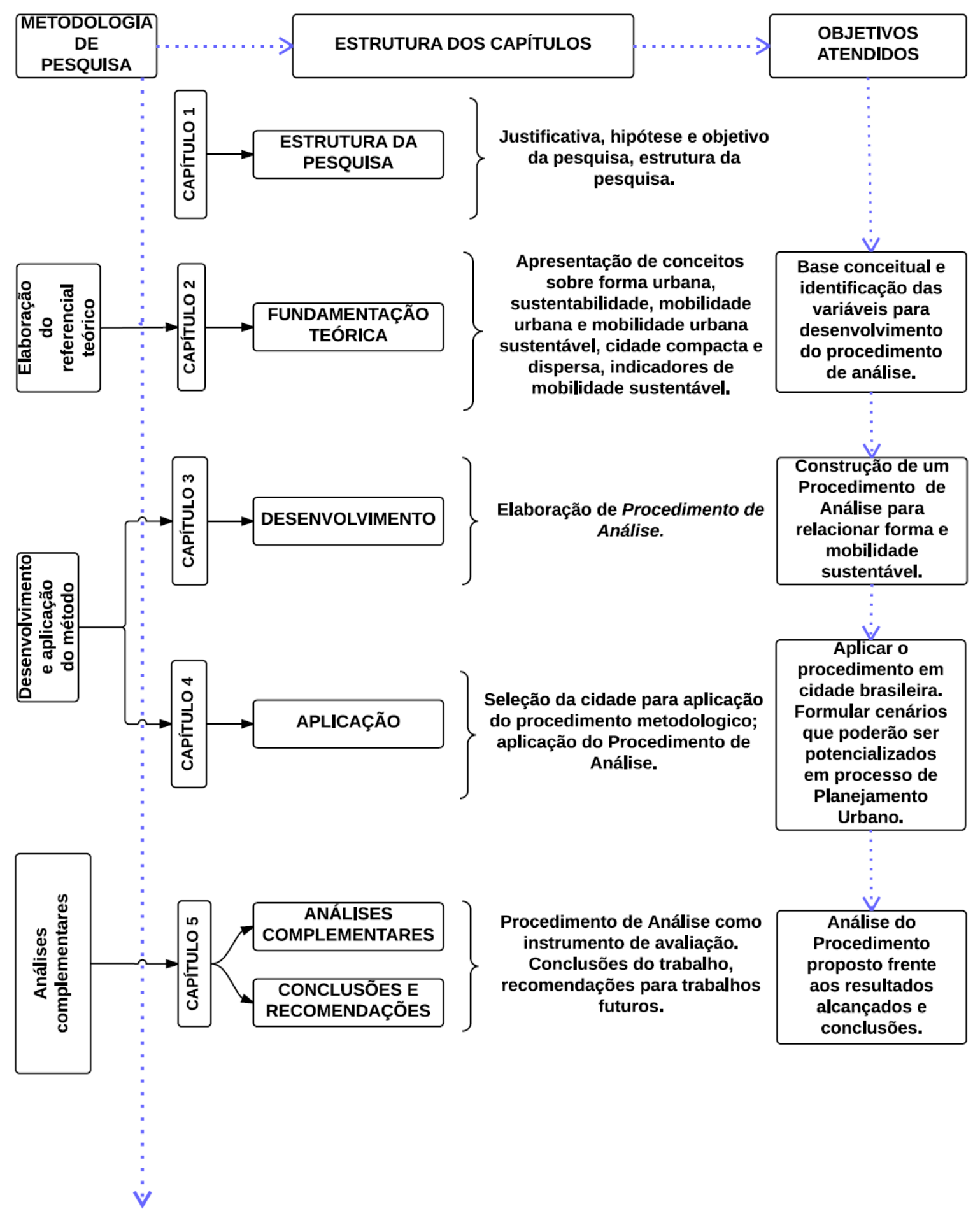

Figura 1: Estrutura metodológica da pesquisa, capítulos da tese e objetivos atendidos. 


\section{CAPÍTULO 2: REVISÃO DE LITERATURA}

\section{INTRODUÇÃO}

Este capítulo contempla a revisão de literatura e a elaboração de um referencial teórico para definir os elementos da forma urbana que se relacionam à mobilidade urbana sustentável. Serão abordados os seguintes aspectos: (i) inserção do tema de pesquisa; (ii) mobilidade urbana e mobilidade urbana sustentável; (iii) conceitos sobre forma urbana e sustentabilidade; (iv) características da cidade compacta e dispersa e (iv) indicadores de mobilidade urbana sustentável. Por fim, serão definidas as variáveis relevantes identificadas na literatura a serem utilizadas na etapa seguinte, de acordo com a elaboração de Procedimento de Análise Espacial.

\subsection{Inserção do tema da pesquisa}

A opção preliminar da pesquisa consistiu no estabelecimento do contexto. Propõe-se aqui delimitar no campo disciplinar da arquitetura e urbanismo, mesmo compreendendo que os temas forma urbana e mobilidade urbana envolvem diversas áreas científicas e contextos individualizados.

A cidade assumida como um sistema resultante da interação entre os vários atributos que a compõem e que se articulam entre si e, sob a perspectiva da forma urbana, é relevante para compreender como as relações interpartes podem influenciar a mobilidade urbana sustentável. Forma urbana é compreendida a partir das articulações espaciais, em que a arquitetura é assumida como qualquer espaço socialmente produzido e utilizado (HOLANDA, 2002).

Segundo Holanda (2002), a "arquitetura" é usada tanto para designar um produto (arquitetura da cidade, arquitetura dos edifícios), como o processo de sua produção. Tal processo também é constituinte da sociedade, em que há expectativas a atender em função do desempenho presumido. "Edifícios e cidades são feitos para satisfazer o interesse de quem os constrói ou daqueles a quem pretende representar” (HOLANDA, 2002).

Pode-se avaliar o desempenho da configuração dos espaços em relação às expectativas humanas no âmbito de oito aspectos ou áreas de reflexão arquitetônica. Portanto, projetar a arquitetura seria criar ou desenhar espaços e avaliá-los frente a (HOLANDA, 2010): 
i. Aspectos funcionais: O lugar satisfaz às exigências práticas da vida cotidiana em termos de tipo e quantidade de espaços para as atividades; e seu inter-relacionamento?

ii. Aspectos bioclimáticos: O lugar implica condições adequadas de iluminação, acústica, temperatura, umidade, velocidade do vento e qualidade do ar?

iii. Aspectos econômicos: Os custos de implementação, manutenção e uso dos lugares são compatíveis com o poder aquisitivo das pessoas implicadas?

iv. Aspectos sociológicos: A configuração da forma-espaço (vazios, cheios e suas relações) implica maneiras desejáveis de indivíduos e grupos (classes sociais, gênero, gerações etc.) se localizarem nos lugares e de se moverem por eles e, consequentemente, condições desejadas para encontros e esquivanças interpessoais, assim como para visibilidade do outro? O tipo, quantidade e localização relativa das atividades implicam desejáveis padrões de utilização dos lugares, no espaço e no tempo?

v. Aspectos topoceptivos: O lugar é legível visualmente, isto é, ele tem uma identidade? O lugar oferece boas condições para a orientabilidade?

vi. Aspectos afetivos: O lugar tem uma personalidade afetiva? Como ele afeta o estado emocional das pessoas?

vii. Aspectos simbólicos: O lugar é rico em elementos arquitetônicos que remetam a outros elementos, maiores que o lugar, ou a elementos de natureza diversa - valores, ideias, história?

viii. Aspectos estéticos: O lugar é belo, isto é, há características de um todo estruturado e qualidades de simplicidade/complexidade, igualdade/dominância, similaridade/diferença, que remetem a qualidades de clareza e originalidade, e por sua vez a pregnância, implicando uma estimulação autônoma dos sentidos para além de questões práticas? O lugar é uma obra de arte, por veicular uma visão de mundo? Sua forma-espaço implica uma filosofia?

Os aspectos mencionados podem ser analisados de acordo com três dimensões: ética, que tem como foco a satisfação das expectativas do homem relativas às necessidades de seu relacionamento com o seu semelhante; estética, em que os lugares podem ser examinados em função de sua beleza; e ecológica ou sustentável, que define como as relações entre o homem e a natureza se rebatem na arquitetura, por meio da qual se verifica a medida da sustentabilidade em relação ao espaço construído, ante seu impacto no meio ambiente natural. Sabe-se que a dominação do homem sobre a natureza e a sua transformação radical tem tornando-se um problema para as cidades modernas (Holanda e Kohlsdorf, 2004), a afetar a qualidade de vida. 
Por fim, Holanda (2002) define que a arquitetura pode ser tratada como variável dependente e independente. Como variável dependente, é determinada pelo ambiente socionatural em que se realiza, exemplo: clima, relevo, hidrografia, geologia (ambiente natural), conhecimento científico-tecnológico, interesses econômicos e políticos, ideológicos (ambiente social). Como variável independente, a arquitetura tem efeitos, impacta a vida das pessoas e meio natural.

Nesta pesquisa, o destaque é para o processo de produção da cidade ou, como coloca Holanda (2010), a "produção do espaço artificial". A arquitetura será vista como variável independente em que serão considerados os impactos do meio construído sobre o meio natural $^{5}$ e, consequentemente, na vida das pessoas. Serão explorados os aspectos funcionais (desempenho do espaço), com ênfase na dimensão sustentável, tendo como objeto de pesquisa a forma urbana e mobilidade urbana.

\subsection{Mobilidade Urbana}

A definição de mobilidade urbana, segundo Medeiros e Borba (2011), é ampla e contempla significados que dizem respeito à própria dinâmica e permanência das cidades. A análise etimológica do termo mobilidade vem do Latim "Mobilis", que significa "o que pode ser movido, deslocado, em movimento”, ou seja, o termo contempla noções de circulação no espaço urbano.

De acordo com Kneib (2012), são diversos os conceitos e definições relacionados à mobilidade, principalmente no Brasil, pois se trata de um termo recente, que também foi utilizado como sinônimo de transporte: em função disso, a consolidação e apreensão do conceito conformam um desafio. O que se sabe ao certo é que a busca por mobilidade urbana de maior qualidade deve contemplar a análise de uma série de variáveis.

Para Magalhães e Yamashita (2006), o conceito que melhor representa o termo mobilidade e foca em aspectos mais específicos da área de transporte e planejamento urbano é: “a faculdade de pessoas ou grupos de pessoas e cargas de serem deslocados, no espaço e no tempo, tendo como objetivo a satisfação das necessidades pessoais e coletivas”.

Para Pires (2008), a mobilidade está relacionada com a duração dos deslocamentos, a origem e o destino das viagens e as técnicas que podem ser colocadas em uso para sua

\footnotetext{
${ }^{5} \mathrm{O}$ resultado da arquitetura pode ser bastante diferente daquele originalmente previsto, podendo trazer prejuízos em relação à sustentabilidade ambiental.
} 
efetivação. Para se deslocarem os indivíduos podem utilizar-se de esforço próprio (pedestre) de meios de transporte não-motorizados ou motorizados. De maneira geral, a mobilidade é a forma de acesso às atividades urbanas, como trabalho, estudo, lazer, influenciando o desenvolvimento urbano e pode ser afetada por fatores como renda do indivíduo, escolaridade, idade, sexo, posse de automóvel, oferta e custo do transporte público e localização dos destinos (MINISTÉRIO DAS CIDADES, 2005; VASCONCELLOS, 2005).

O significado mais expressivo pode ser sintetizado por aquele adotado pelo Ministério das Cidades (2005), em que a mobilidade urbana é entendida como "um atributo das cidades e se refere à facilidade de deslocamento de pessoas e bens no espaço urbano. Tais deslocamentos são feitos através de veículos, vias, e toda infraestrutura (vias, calçadas, etc)".

A análise da literatura expõe diversos conceitos para mobilidade urbana. Conforme os citados acima. O consenso incide na ideia do movimento, mobilidade é movimentar-se. A definição apresentada pelo Ministério das Cidades parece estar vinculada ao desempenho da infraestrutura, pois nele a mobilidade depende da organização, funcionamento e desempenho de vias, conceito restrito à área de transportes. Não estão incorporados outros elementos que podem influenciar para um bom desempenho da mobilidade urbana, como os relacionados à forma urbana.

O relatório da Agência Nacional de Transportes Públicos (ANTP, 2012) sobre a divisão modal aponta para o atual perfil da mobilidade em cidades brasileiras. De acordo com a Figura 2, pode-se fazer a leitura de que a maioria das viagens é realizada a pé e de bicicleta (40\%), seguida do transporte individual motorizado (27\%) e transporte público (29\%).

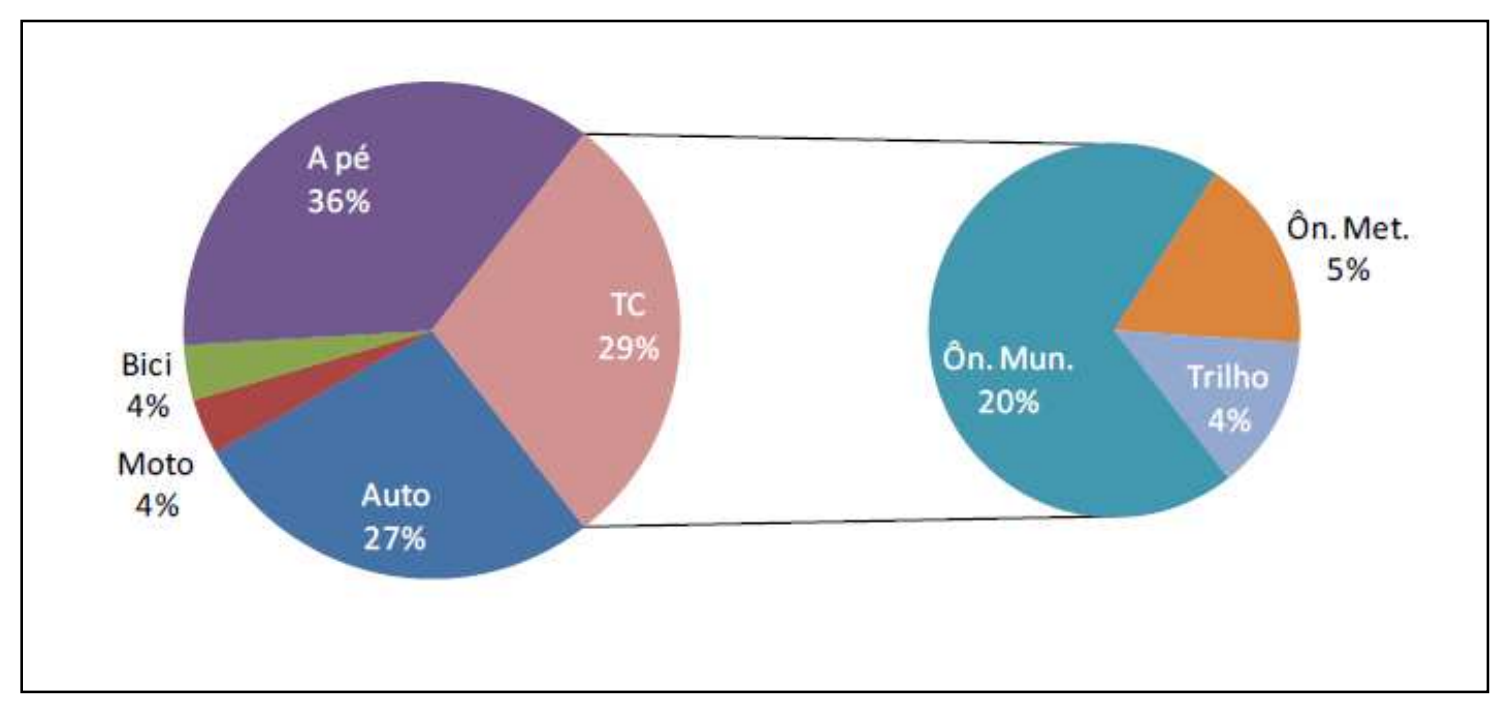

Figura 2: Distribuição de viagens por modal no Brasil. Fonte: ANTP, (2012). 
Ainda de acordo com ANTP (2012), quando se avalia a divisão modal por porte de município, verifica-se que a proporção de transporte coletivo (TC) reduz-se em função do tamanho da cidade, passando de $31,8 \%$ para $23,7 \%$, entre os municípios maiores e menores. $\mathrm{O}$ fenômeno repete-se quando analisada a participação do transporte individual (TI), que passa de $32,6 \%$ para $24 \%$. Por outro lado, a utilização do transporte não-motorizado (TNM), aumenta com a redução do tamanho do município passando de $35,6 \%$ para $52,4 \%$. Esses números indicam a necessidade de diferentes olhares em relação às políticas de mobilidade urbana em função do porte do município, pois, enquanto os maiores possuem maior quantidade de viagens motorizadas, os menores apresentam maior quantidade de viagens no transporte não motorizado (Figura 3).

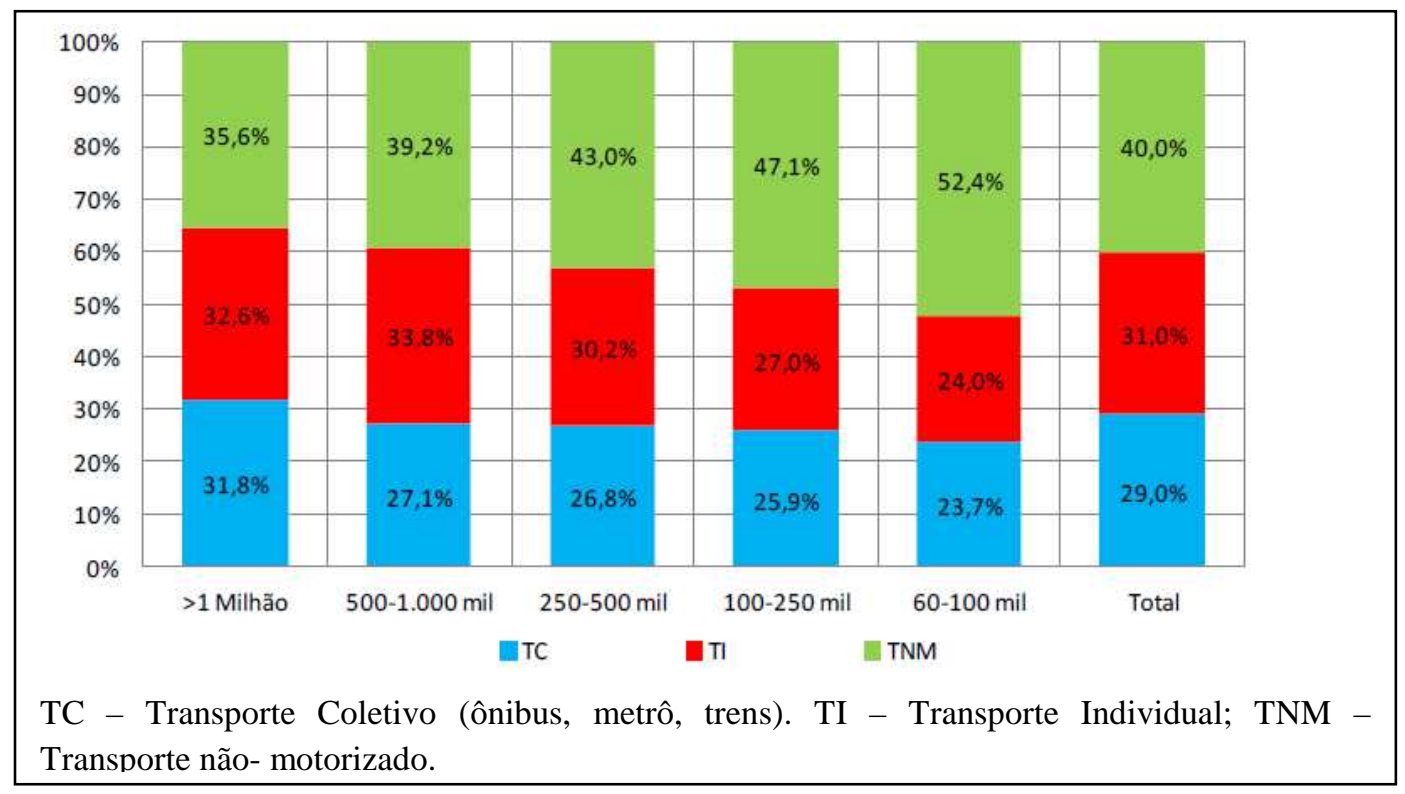

Figura 3: Divisão modal por porte de município. Fonte: ANTP, (2012).

As cidades de pequeno porte aproximam-se de valores mais satisfatórios em relação ao impacto da mobilidade, pois a redução das distâncias média dos deslocamentos incentiva a utilização do transporte não-motorizado. Em relação a isso, pode-se fazer a leitura de que a criação de centralidades ${ }^{6}$ pode estimular as viagens a pé e de bicicleta, pois funciona nas cidades de porte menor. O sistema de mobilidade urbana dos grandes centros urbanos brasileiros caracteriza-se pela utilização intensa do transporte individual, trazendo efeitos negativos na qualidade de vida da população.

\footnotetext{
${ }^{6}$ Kneib (2014) explora o tema: criação de centralidades urbanas (subcentros) em suas pesquisas, como meio de incentivar maior utilização do transporte não-motorizado e transporte público (cf. Kneib, 2008; Kneib, 2014).
} 
O Instituto de Pesquisas Econômicas e Aplicadas (IPEA, 2011) publicou um estudo no qual se verificou que o padrão de mobilidade no Brasil é centrado no uso intensivo do transporte motorizado individual. O cenário pode acarretar uma série de externalidades negativas para as cidades, com destaque aos problemas ambientais, perdas de tempo em congestionamentos e aumento de acidentes de trânsito.

Em termos socioeconômicos, outra pesquisa realizada pelo IPEA, denominada SIPS Sistema de Indicadores de Percepção Social (2011) para mobilidade urbana, identificou que quanto maior o nível de escolaridade mais se opta pelo transporte individual, enquanto que as pessoas que têm baixo nível de escolaridade tendem a usar o transporte público, conforme ilustra a Figura 4.

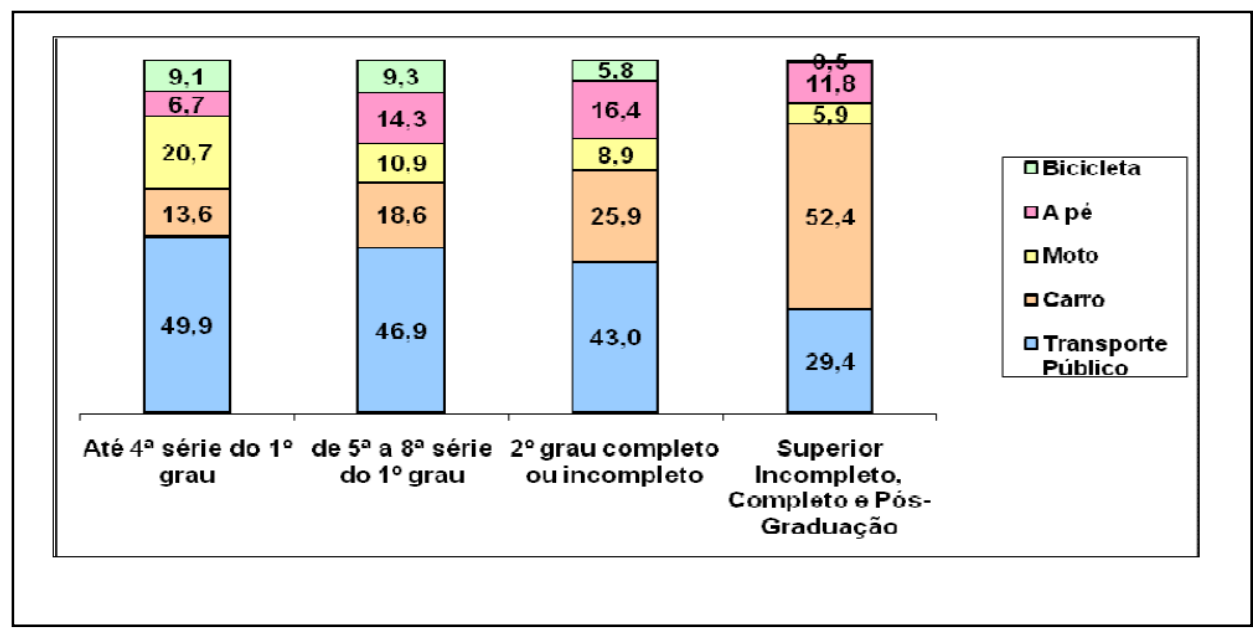

Figura 4: Meio de Transporte mais utilizado por escolaridade (\%). Fonte: IPEA (2011).

Com relação ao consumo de energia, segundo Leite e Awad (2012), as cidades consomem cada vez mais: entre 1950 e 2005, a população urbana mundial cresceu entre $29 \%$ e 49\%, enquanto a emissão de carbono pulou de 1.630 para 7.985 milhões de toneladas. As emissões de carbono derivadas de transporte estão crescendo mais rapidamente nas megacidades de países emergentes.

No Brasil, as pessoas consomem, por ano, cerca de 13,5 milhões de TEP (Toneladas Equivalentes de Petróleo) nos seus deslocamentos: $76 \%$ dessa energia é gasta no transporte individual (auto e moto), enquanto $24 \%$ destina-se ao transporte público. São emitidos 29,9 milhões de toneladas de poluentes (soma dos poluentes locais e $\mathrm{CO}_{2}$ ) por ano nos deslocamentos e a maior parte desse valor (60\%) é emitida pelos automóveis particulares, seguidos do transporte público com 35\%, conforme ilustra a Figura 5 (ANTP, 2012). 

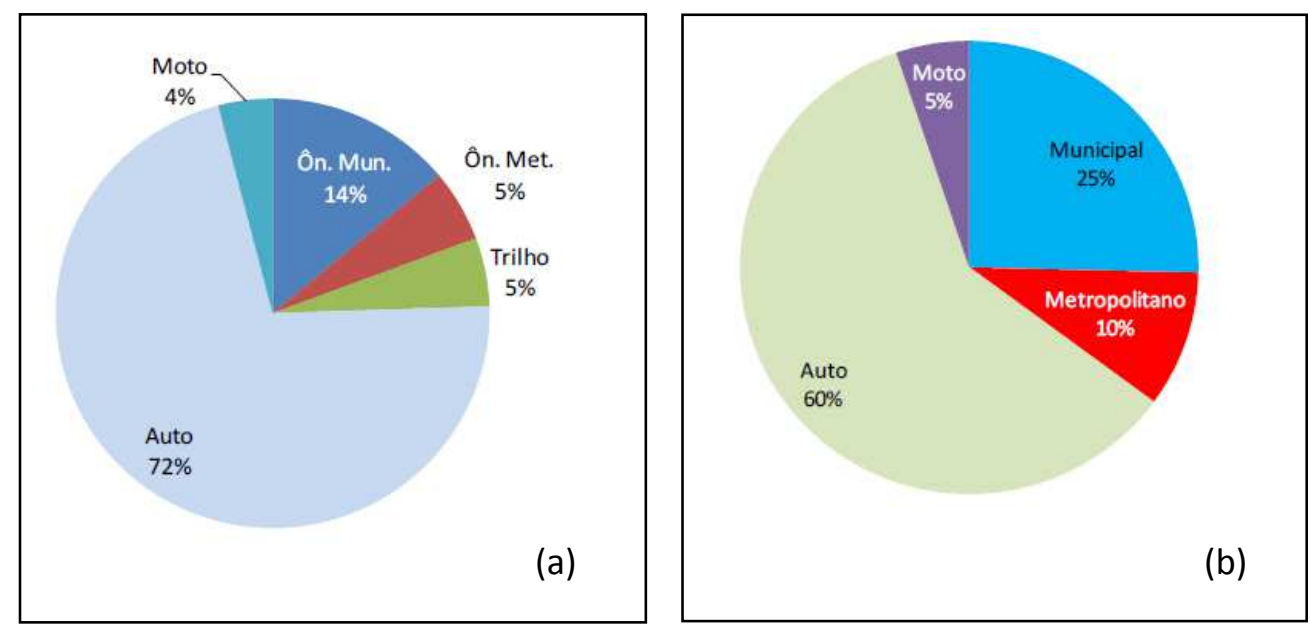

Figura 5: (a) Consumo de energia por modo; (b) Emissão de poluentes por modo (CO2). Fonte: ANTP, (2012).

$\mathrm{O}$ aumento da necessidade de deslocamento em áreas urbanas resultou em um quadro de agravamento para mobilidade urbana, implicando em impactos negativos sobre os ambientes local e global. Esses impactos incluem, além da emissão de poluentes, ruídos, congestionamentos, acidentes, uso de fontes não renováveis, fragmentação de comunidades, entre outros (COSTA, 2008). O agravamento dos problemas de mobilidade, principalmente no que diz respeito às questões ambientais, tem reforçado a necessidade de uma nova abordagem para mobilidade urbana, considerando os conceitos de sustentabilidade. É necessário criar iniciativas para promover a mobilidade urbana sustentável, tema que será discutido no próximo item.

\subsection{Mobilidade Urbana Sustentável}

As atividades ligadas à mobilidade urbana produzem fortes impactos no meio ambiente. A multiplicidade das atividades, a dimensão do espaço urbano, a disponibilidade de transporte e as características da população podem influenciar no comportamento da mobilidade, afetando diretamente o desenvolvimento de cidades ou regiões e impactando a sustentabilidade ambiental (DPP, 2011).

Em função disso, atualmente, tem sido agregada ao conceito de mobilidade urbana a sustentabilidade ambiental. Construir uma mobilidade urbana sustentável envolve políticas que, além de proporcionar o acesso amplo e democrático aos espaços urbanos, sejam um importante meio para o alcance do desenvolvimento social, econômico e ambiental, de forma equilibrada, sem prejudicar o meio ambiente.

A OECD (Organization for Economic Cooperation and Development) acolheu a seguinte definição para transporte ambientalmente sustentável: 
Permite a satisfação das necessidades básicas de acesso e mobilidade de pessoas, empresas e sociedade, de forma compatível com saúde humana e equilíbrio do ecossistema, promovendo igualdade dentro das gerações e entre as mesmas. Possui custos aceitáveis, funciona eficientemente, oferece a possibilidade de escolha do modo de transporte e apoia uma economia dinâmica e o desenvolvimento regional. Limita as emissões e os resíduos em função da capacidade da Terra para absorvê-los, utiliza recursos renováveis a um ritmo inferior ou igual a sua renovação, utiliza os recursos não renováveis a um ritmo inferior ou igual ao desenvolvimento de substitutos renováveis e reduz ao mínimo o uso do solo e a emissão de ruído (OECD, 2002).

Não há uma definição única sobre a sustentabilidade da mobilidade mas, de maneira geral, o seu conceito resulta do processo de discussão da própria acepção de desenvolvimento sustentável, que surgiu na década de 1980. Fundamenta-se na premissa de "satisfação das necessidades do presente sem comprometer a capacidade das gerações futuras de satisfazerem as suas próprias necessidades” (WCED, 1987).

Com isso, destaca-se a definição colocada por Boareto (2003), que traz essa visão de sustentabilidade relacionada à mobilidade como uma extensão do conceito utilizado na área ambiental: é a "capacidade de fazer as viagens necessárias para realização de seus direitos básicos de cidadão, com o menor gasto de energia possível e menor impacto no meio ambiente, tornando-a ecologicamente sustentável”.

Seabra (2013) trouxe uma discussão teórica sobre a definição de sustentabilidade na área de transporte, desde o surgimento do termo sustentável, seguindo para a escala urbana, até abordar especificamente o transporte sustentável, considerando diversos eventos que foram realizados ao longo do tempo. A autora destaca a contribuição, o foco principal, a dimensão da sustentabilidade e a escala a que se refere, conforme apontado no Quadro 1. 
Quadro 1: Histórico da evolução conceitual sobre sustentabilidade em transportes.

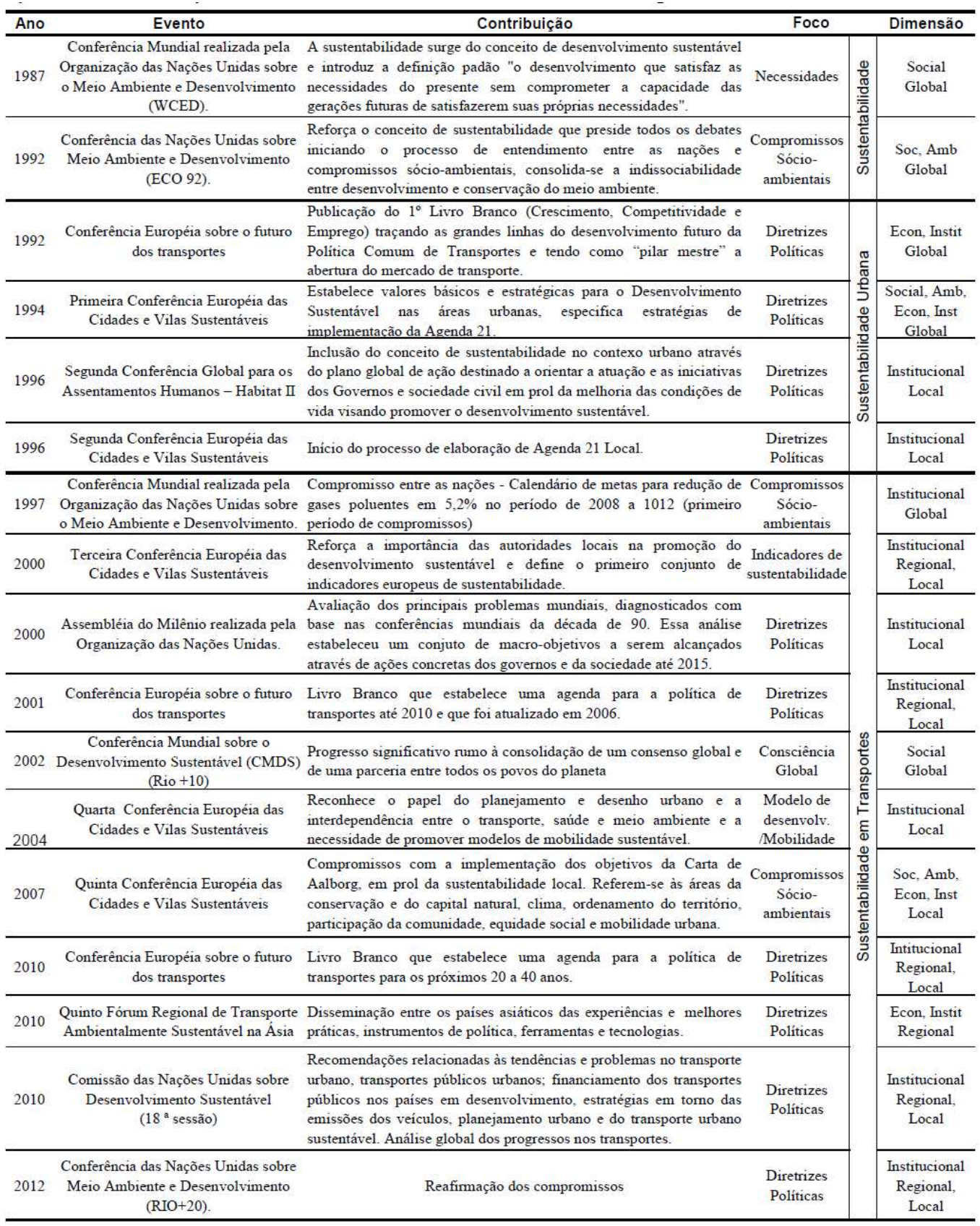

Fonte: Seabra, (2013).

Para Campos (2007), a mobilidade urbana, dentro de uma visão de sustentabilidade, pode ser alcançada sob dois enfoques: um relacionado com a adequação de oferta de transporte ao contexto socioeconômico e outro com a qualidade ambiental. Para o primeiro, visa proporcionar acesso aos bens e serviços de forma eficiente e equitativa, por meio de ações sobre o uso e ocupação do solo e gestão dos transportes. O contexto ambiental está relacionado com as tecnologias de transporte, como elemento que pode contribuir na redução dos impactos ambientais provocados pelo intenso uso de transporte. Existe, neste caso, uma 
preocupação quanto ao tipo de combustível a ser utilizado no transporte público, em que pese a redução no consumo de combustíveis fósseis, buscando-se o uso de energia mais limpa. Deve-se considerar, também, no contexto ambiental, elementos que gerem melhor fluidez do tráfego e aumentem a segurança urbana. No Quadro 2, são demonstradas as principais estratégias para alcançar a mobilidade sustentável nos contextos socioeconômico e ambiental, de acordo com Campos (2007).

Quadro 2: Estratégias socioeconômicas e ambientais para auxiliar a mobilidade sustentável.

\begin{tabular}{|c|c|}
\hline Estratégias Socioeconômicas & Estratégias Ambientais \\
\hline $\begin{array}{l}\text { - Desenvolvimento urbano orientado ao } \\
\text { transporte; } \\
\text { - Incentivo ao deslocamento de curta } \\
\text { distância; } \\
\text { - Restrições ao uso do automóvel; } \\
\text { - Oferta adequada e integração de } \\
\text { transporte público; } \\
\text { - Adensamento na proximidade dos } \\
\text { corredores e estações de transporte } \\
\text { público; } \\
\text { - Tarifa adequada à demanda e oferta de } \\
\text { transporte público. }\end{array}$ & $\begin{array}{l}\text { - Investimento em transporte público utilizando } \\
\text { energia limpa; } \\
\text { - Políticas de restrição de uso do transporte } \\
\text { individual em áreas já poluídas; } \\
\text { - Aumento da qualidade do transporte público; } \\
\text { - Implantação de sistemas de controle de tráfego } \\
\text { e de velocidade; } \\
\text { - Adequação de veículos de carga, vias e pontos } \\
\text { de parada; } \\
\text { - Conforto urbano: calçadas adequadas, } \\
\text { ciclovias, segurança em travessias e arborização } \\
\text { de vias. }\end{array}$ \\
\hline
\end{tabular}

Fonte: Campos, (2007).

As estratégias apontadas por Campos (2007) exigem tanto aspectos relacionados ao planejamento de transporte quanto a adoção de políticas na área do planejamento urbano para obtenção de uma cidade sustentável em termos de mobilidade. Aqui se destaca a compreensão de parâmetros urbanísticos, ligados aos aspectos da forma urbana, como zoneamento, densidade e condições de parcelamentos do solo urbano, tendo em vista que tais elementos possuem implicações na geração de viagens e deslocamentos dentro da cidade, podendo influenciar sobremaneira a mobilidade urbana sustentável. Porém, há pouco destaque aos elementos da forma urbana, pois, conforme descrição do Quadro 2, há mais alternativas ligadas ao planejamento de transporte e trânsito do que propriamente medidas ligadas ao planejamento urbano com tratamento específico da forma urbana.

A revisão de literatura acerca da mobilidade sustentável relaciona, primordialmente, o seu desempenho aos aspectos de transporte e circulação, com pouca ênfase nos aspectos morfológicos estruturantes com vistas ao planejamento urbano. Quando se olha para os objetivos principais da Política Nacional de Mobilidade Urbana, instituídos pela Lei Federal $\mathrm{n}^{\circ} 12.587$ (Brasil, 2012), com relação aos elementos estruturadores para elaboração dos 
planos de mobilidade ${ }^{7}$, percebe-se uma preocupação centrada na mudança de matriz de deslocamento da população, estimulando o aumento da participação do transporte coletivo e não-motorizado como alternativa para melhorar o desempenho ambiental da mobilidade. São medidas centradas exclusivamente nas políticas de transporte.

Indubitavelmente, a Lei Federal $n^{\circ} 12.587$ (Brasil, 2012) ou Lei da Mobilidade é um marco na questão da mobilidade urbana e traz, em linhas gerais, desdobramentos relativos ao desenvolvimento urbano, sustentabilidade ambiental e inclusão social. Entretanto, há pouca ou nenhuma indicação sobre os elementos da forma urbana (mistura de uso, contenção da expansão, forma compacta, alta densidade, entre outros - cf. item 2.4) como fatores relevantes para o alcance da mobilidade sustentável.

Além disso, é importante reconhecer que o desenho urbano, elemento estruturador da forma urbana, é um fator que também condiciona os padrões de mobilidade urbana em diferentes escalas. Em nível de macroescala, a estruturação do espaço urbano é influenciada pela implantação das grandes infraestruturas de transporte, bem como pela relação que apresentam com a localização de atividades. Na microescala reconhece-se a importância da qualidade do espaço urbano enquanto fator que pode condicionar a utilização de transportes não-motorizados (MINISTÉRIO DAS CIDADES, 2006). A qualidade do espaço, neste caso, está vinculada ao grau de acessibilidade ${ }^{8}$ que a malha viária (elemento da forma urbana) pode oferecer para os deslocamentos acontecerem de maneira eficiente, tornando-se um elemento importante para o alcance da mobilidade sustentável.

Por tais colocações acerca da mobilidade urbana sustentável, percebe-se pouca ou quase nenhuma menção aos elementos da forma urbana como fatores que contribuem para atuação nesse processo. Parece não haver o entendimento de que estes elementos, articulados aos de transporte e circulação, possam ser decisivos e potencializados para melhorar a circulação em uma cidade, revertendo-se em ganho para mobilidade sustentável.

\footnotetext{
${ }^{7}$ Plano de Mobilidade urbana é o instrumento de efetivação da Política Nacional de Mobilidade Urbana (consta na Lei $\mathrm{N}^{\circ} 12.587$ de 3 de Janeiro de 2012) que deve ser integrado ou compatível com os planos diretores ou inseridos neles. É um instrumento obrigatório para municípios com mais de 20.000 habitantes.

${ }^{8} \mathrm{O}$ conceito de acessibilidade tem sido caracterizado por grande diversidade de definições, algumas se confundido com o conceito de mobilidade. Aqui a acessibilidade será entendida como "facilidade de acesso aos diferentes locais da área considerada" (Paiva, 2010). De acordo com o autor, os estudos sobre acessibilidade são variados e possuem diferentes dimensões, no entanto, todos visam quantificar ou medir as dificuldades e/ou facilidades de acesso.
} 


\subsection{Forma Urbana}

Ao se falar de forma urbana, é importante refletir sobre como esse tema, ou área de conhecimento (Cf. Holanda et al., 2000), é complexo. O estudo da forma urbana ou morfologia urbana ${ }^{9}$ vem sendo explorado de diversas maneiras na academia e pode ser tratado por uma abordagem no campo do detalhamento formal, por meio do conjunto de residências, malha viária e densidades que compõem o espaço urbano. Além disso, o campo de estudo pode optar por uma abordagem social que se vincula à forma cultural de determinados assentamentos como: tradição, cultura, costumes e identificação dos habitantes que ali coexistem (CANTALICE, 2012).

A forma urbana pode ser definida como a delimitação física da cidade, espaço onde ocorre a vida social e que está em constante transformação, "existem tanto tipos de cidades quanto número de cidades existentes, pois uma cidade nunca é igual à outra, levando em consideração os diversos aspectos para sua formação, desde a geografia local à crença de seus habitantes” (CANTALICE, 2012). Apesar de cada cidade guardar características próprias e diferenciadas em relação ao seu formato urbano, é possível reconhecer elementos recorrentes que emergem em qualquer análise sobre forma urbana.

$\mathrm{O}$ conceito mais geral de forma de um objeto refere-se à aparência exterior ou configuração física. A forma da cidade ou forma urbana resulta da maneira como as partes se estruturam, de modo que a configuração são as relações entre as partes constituintes e do desenho urbano impresso pelo homem. As características físicas do espaço urbano conformam a materialização da forma da cidade.

Holanda et al (2000) trazem uma leitura sobre o estado da arte em relação à forma urbana e consideram que o conceito adere ao significado de espaço urbano, destacando que "qualquer espaço em que nos encontremos é fisicamente delimitado, a ponto de estruturamos sua noção a partir da consciência das relações topológicas e perspectivas entre nosso corpo e as superfícies que realizam a demarcação do espaço que estamos”. Falar em forma urbana

\footnotetext{
${ }^{9}$ Os trabalhos de morfologia urbana podem ser divididos em estudos cognitivos e normativos. No primeiro caso estão incluídos os que almejam produzir explicações para a forma urbana "como é" ou "o porquê". No segundo, estão aqueles que buscam determinar ou prescrever o modo como a cidade deveria ser planejada, "como deveria ser" (GAUTHIER; GILLILAND, 2006 apud REGO MENEGETTI 2011). Rego e Meneguetti (2011) salientam que as lentes para se olhar a forma urbana, assim como o vocabulário empregado, diferem, porque, como a morfologia urbana trata do estudo da forma urbana e dos processos e pessoas que a formataram, interage com uma ampla gama de disciplinas: desenho urbano, geografia urbana, história da cidade, dentre outras. O "chão comum" para os pesquisadores ligados à morfologia urbana é o fato de que a cidade pode ser lida e analisada por meio da sua forma física.
} 
ou espaço urbano remete à abordagem de organização social da cidade a partir de suas características configurativas.

Lamas (1999) fornece outra abordagem, considerando forma urbana como sendo o "modo como se organizam os elementos morfológicos que constituem e definem o espaço urbano, relativamente à materialização dos aspectos de organização funcional e quantitativa e dos aspectos qualitativos e figurativos", que compreendem:

i. Aspectos quantitativos: tudo que pode ser quantificável densidades, superfícies, fluxos, coeficientes volumétricos, dimensões, perfis, etc. Todos os dados que podem ser utilizados para controlar o aspecto físico da cidade;

ii. Aspectos de organização funcional: relacionam-se com as atividades humanas, uso da área em questão, ou seja, tipo do uso do solo (residencial, escolar, comercial...);

iii. Aspectos qualitativos: referem-se ao tratamento dado aos espaços urbanos para imprimir maior conforto ou comodidade. $\mathrm{O}$ meio urbano pode ser caracterizado pelo tipo de pavimento, adaptação ao clima (abrigo dos ventos e chuvas), acessibilidade, etc;

iv. Aspectos figurativos: relacionam-se com a comunicação estética. Entende-se que, apesar de haver uma área de sobreposição entre os aspectos qualitativos e estéticos, convém distinguir que os aspectos qualitativos não são necessariamente estéticos - um ambiente com alto grau estético não implica necessariamente em boa comodidade ou conforto e vice-versa (LAMAS, 1999).

A classificação proposta por Lamas é relevante e traduz os elementos que se destacam para estruturar a forma urbana. No entanto, é importante compreender a fragilidade da estratégia pela sobreposição, já que os aspectos de organização funcional também podem ser quantificáveis e os aspectos figurativos podem ser qualificados.

A forma urbana, segundo Anderson et al. (1996), pode ser compreendida como a configuração de elementos fixos que se distribuem em uma determinada área urbana e que refletem os padrões de uso do solo, as densidades, a configuração das redes de transporte e a infraestrutura de comunicação. Duarte et al. (2008) complementam essa análise afirmando que a forma urbana também é resultado de diversos agentes e fatores combinados no espaço e no tempo, como o Estado, o setor privado, a dinâmica social e econômica. Além disso, a forma urbana também está condicionada aos fatores naturais, como topografia, hidrografia e tipo de solo.

Sobre os elementos que compõem a forma urbana, o tecido é um componente elementar na análise morfológica, pois é uma das características mais claramente identificáveis, tanto na leitura da cidade existente quando da projetada. É a partir do desenho 
da malha viária que se estabelecem os limites para implantação de quarteirões e edifícios e a conexão entre as diversas partes da cidade.

Para Panerai (2006), o tecido urbano é constituído pela superposição de três conjuntos: a rede de vias, os parcelamentos fundiários e as edificações. Rego e Meneguetti (2011) acrescentam os parques, as praças e os monumentos, que seriam os espaços livres entre ruas e quadras. A articulação desses elementos é conduzida pela malha viária e a forma urbana é o produto dessas relações estabelecidas pelo homem entre a forma edificada, a forma dos espaços de permanência e a circulação. A forma urbana apresenta diferentes dimensões espaciais de análise, de acordo com a escala de observação: a rua, o bairro, a cidade, a quadra ou até mesmo a região metropolitana (LAMAS, 1999; COSTA, 2007).

Medeiros (2013) aprofunda as análises e destaca que "a cidade não é apenas um sistema viário de vias e avenidas articuladas ou a disposição de espaços abertos e fechados, mas sim um complexo conjunto de relações: um lugar para onde convergem, se concentram e interagem grupos de relações sociais econômicas, culturais e politicas”. A forma que tomará a cidade é resultante dessas interconexões.

A partir da exposição a respeito dos conceitos sobre forma urbana, é possível verificar a necessidade do cruzamento de diferentes leituras e informações para explicar a cidade. Como parâmetros conceituais, esta pesquisa considera que a forma urbana pode ser analisada sob dois enfoques: formal e espacial ${ }^{10}$. $\mathrm{O}$ aspecto formal está ligado aos cheios e vazios, aos aspectos volumétricos, índices urbanísticos. O aspecto espacial diz respeito à estrutura espacial, ou seja, tem-se que os vazios fechados pelos cheios estão estruturados, em que o elemento estruturante seria o desenho da malha viária. Isto posto, são identificadas duas famílias de variáveis para forma urbana que levem em conta i. o aspecto formal e ; ii. o aspecto espacial. Esse assunto será retomado quando da seleção das variáveis da forma urbana que serão utilizadas nesta pesquisa, para que se possa estabelecer a família de variáveis afins à mobilidade sustentável.

\subsubsection{Forma urbana e sustentabilidade}

O estudo da relação forma e mobilidade é relevante porque, historicamente, a alteração da forma urbana deu-se em função da tecnologia que ascendeu na área de transporte, conforme destaca Costa (2007) "o crescimento e organização dos espaços urbanos foram

\footnotetext{
${ }^{10}$ Há o entendimento de que os cheios e os vazios dentro de uma área urbana estabelecem a forma urbana. A configuração formal e espacial é a ordenação dos dois tipos de componentes que podem ser separáveis analiticamente.
} 
condicionados ao longo do tempo pelo progresso tecnológico no setor de transportes" e Ferraz e Torres (2004), quando apregoam que “os meios de transporte disponíveis exerceram grande influência na localização, no tamanho e nas características das cidades, bem como nos hábitos da população”. Portanto o entendimento das mudanças pelas quais a forma das cidades passou traz premissas e dados sobre as alterações nos processos de deslocamento das pessoas, ou seja, traz consequências para mobilidade urbana.

Ainda de acordo com Ferraz e Torres (2004), o tamanho das cidades esteve historicamente condicionado a dois fatores: a capacidade de obter suprimentos por meio de produção própria ou de transporte de outras localidades, e a distância máxima que se podia vencer a pé para realizar as atividades relativas à vida urbana.

As mudanças das condições econômicas e da configuração urbana traduziram-se em alterações nas condições de mobilidade individual. O tema é explorado nos trabalhos desenvolvidos por Adams (1970) e Taaffe et al. (1996), relativamente às cidades norteamericanas (COSTA, 2007). A Figura 6 apresenta quatro períodos que demonstram a evolução da tecnologia de transportes que condiciona a forma urbana:

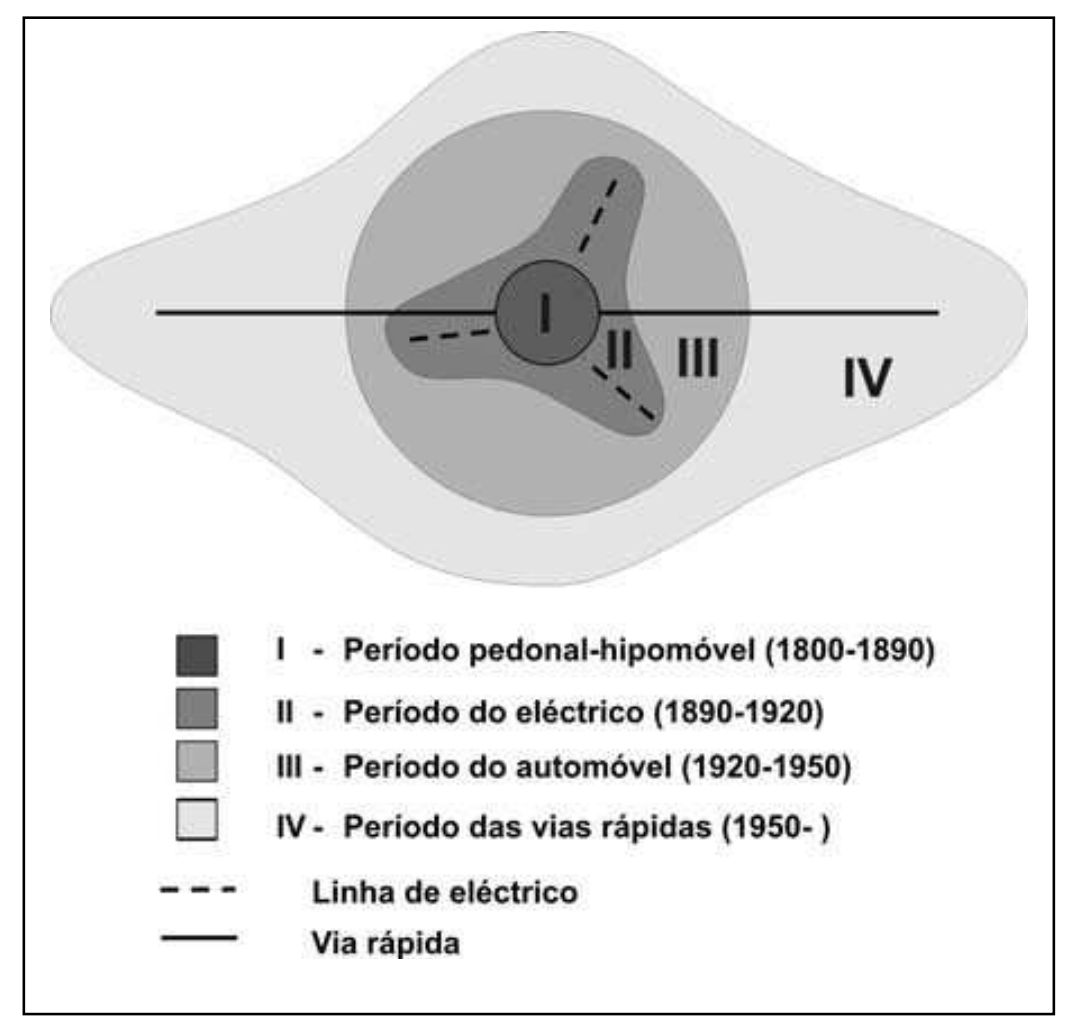

Figura 6: Relação entre forma urbana e tecnologia de transporte - cidades norte-americanas. Fonte: Adams, (1970); Taaffe et al, (1996); Costa (2007). 
i. No primeiro período, que se estende por quase todo século XIX, a mobilidade urbana é feita a pé ou com a utilização de modos hipomóveis, conduzindo a uma configuração urbana compacta, em que os diferentes usos e funções se reuniam: os locais de trabalho e moradia ainda eram próximos;

ii. O segundo período é caracterizado pela introdução do bonde elétrico: a cidade assume uma forma radial, desenvolvendo-se ao longo das linhas que, partindo do centro, começam a alcançar áreas cada vez mais distantes e periféricas. O desenvolvimento de outros meios de transporte propiciou que as atividades pudessem estar mais desarticuladas no espaço urbano; com isso, inicia-se o processo de expansão da mancha da cidade;

iii. No terceiro período acontece a expansão urbana associada à utilização dos modos rodoviários, em particular o automóvel;

iv. O quarto período é caracterizado pelo desenvolvimento de vias rápidas para circulação do automóvel, configurando o estabelecimento de formas urbanas concêntricas ou radiais e a dispersão urbana, permitindo uma maior liberdade na localização dos locais de trabalho e moradia.

O estágio de desenvolvimento tecnológico na área de transportes também aconteceu em outras partes do mundo, em épocas distintas, em maior ou menor grau, assemelhadas ao cenário das cidades norte-americanas. Genericamente, é possível identificar importantes espaços de tempo, conforme ilustra a Figura 7.

Com o surgimento de novas maneiras de circulação, abriu-se a possibilidade de distâncias maiores serem percorridas. Com isso, o espaço urbano alterou seu formato por meio da expansão de seus limites, rompendo a escala do pedestre. A Revolução Industrial, a evolução dos transportes e o crescimento urbano trouxeram uma nova configuração, caracterizando uma forma urbana dispersa, fato este que também tem suas raízes em questões geográficas, políticas e econômicas.

A expansão das cidades promoveu a ênfase no modo de veículo particular ao longo do tempo. O Relatório Buchanan (1963) trouxe essa temática, destacando a importância do automóvel na dispersão do território, aconselhando uma investigação sobre a forma urbana, uma vez que seria necessário rever o desenho urbano no sentido de propiciar a redução dos deslocamentos, sendo, para isso, necessária atenção às variáveis: dimensão, densidade, distribuição dos diferentes usos do solo e aspectos sociais e econômicos. O aumento dos impactos negativos associados à dispersão urbana reavivou a discussão acerca da influência 
que a forma urbana poderia causar sobre vários aspectos que não colaboram para o desenvolvimento sustentável das cidades.

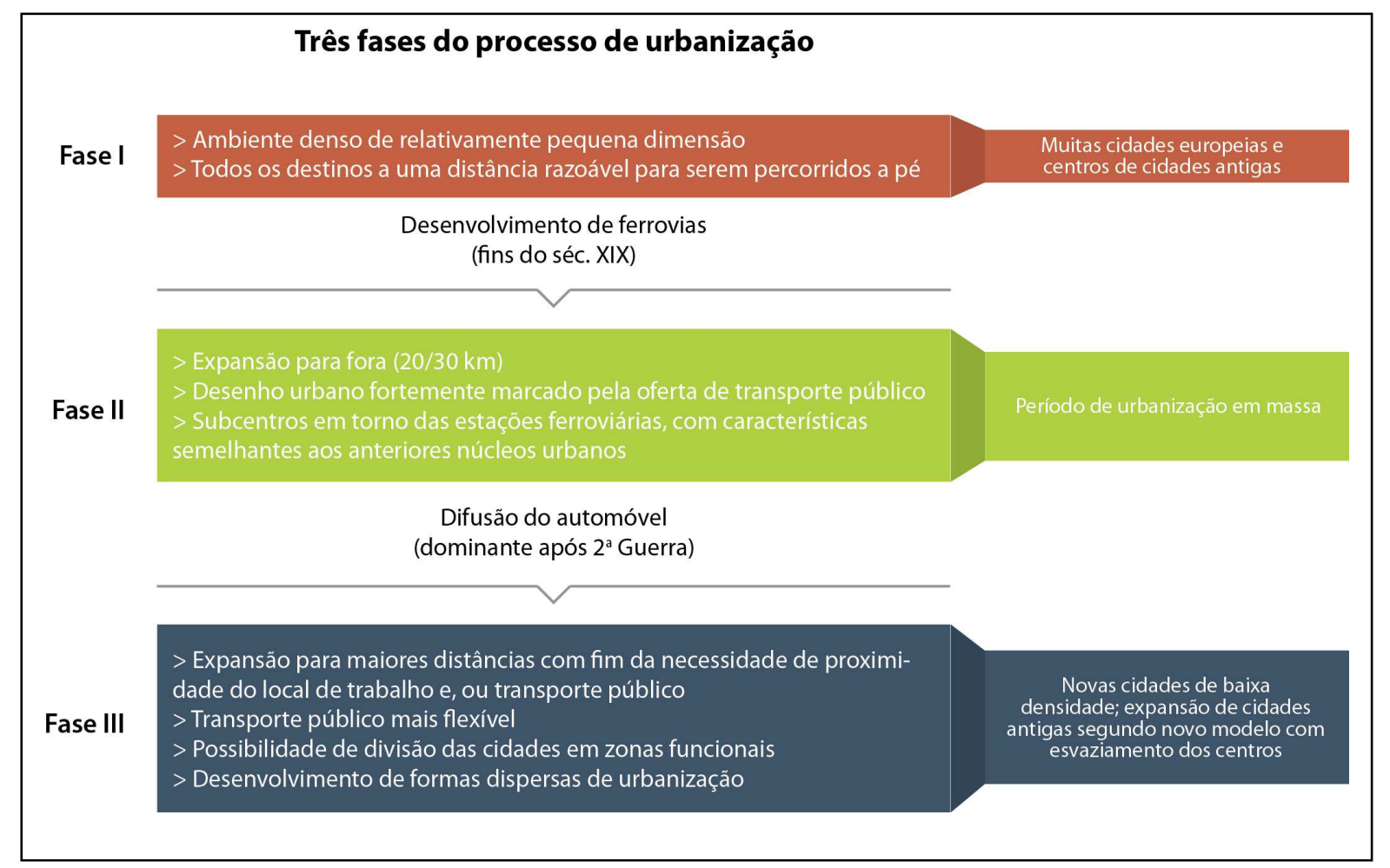

Figura 7: Três fases do processo de urbanização. Fonte: Silva, (2008) adaptado.

A sustentabilidade urbana é um tema que produziu inúmeros debates e conferências, principalmente nas últimas décadas do século XX, em que se evidenciou a grande presença de pessoas vivendo em áreas urbanas, conforme já explicitado na Quadro 1 que consta item 2.3. A abordagem conceitual sobre o desenvolvimento sustentável é tradicionalmente focada nas dimensões econômica, social e ambiental, que consideram os seguintes aspectos:

i. Econômico: os custos associados à construção, operação e manutenção das infraestruturas e serviços de suporte ao desenvolvimento urbano não devem superar as limitações existentes ou comprometer demandas de investimentos em setores prioritários; ii. Social: as cidades devem se equitativas, promovendo oportunidades de acesso aos serviços essenciais para todos;

iii. Ambiental: cidades sustentáveis devem ser projetadas de forma a minimizar a poluição do ar, água, solo, reduzir desperdício e consumo de recursos naturais.

A busca pelo equilíbrio ou, o "espaço" onde deve ocorrer o desenvolvimento para que ele seja sustentável seria a intersecção entre as dimensões econômica, social e ambiental, como apresenta a Figura 8 (MINISTÉRIO DAS CIDADES, 2006): 


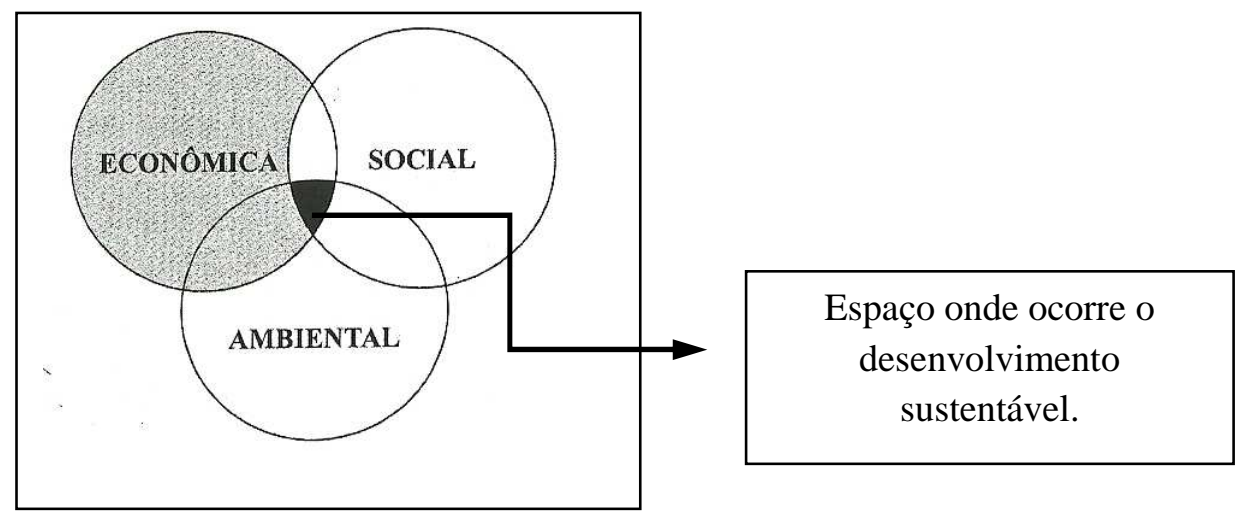

Figura 8: Dimensões consideradas nos diferentes conceitos de sustentabilidade.

Fonte: Adaptado pela autora; Ministério das Cidades, (2006).

Essa discussão ganha uma nova dimensão, relacionando a forma urbana com os critérios de sustentabilidade, emergindo o conceito de forma urbana sustentável. Aqui, a forma urbana sustentável será aquela que permita, simultaneamente, a concretização dos objetivos de redução dos consumos energéticos, promoção da equidade social e a qualidade de vida.

A concepção de cidade sustentável tem estreita relação com a busca de uma forma alternativa de desenvolvimento que possa minimizar os impactos decorrentes da urbanização e que promova a máxima conservação dos recursos naturais. Inclui-se aqui a busca por uma forma urbana ou por um conjunto de características de determinada forma que possa potencializar a mobilidade sustentável. No próximo item, serão destacados os aspectos conceituais do formato urbano compacto e disperso e de suas implicações para mobilidade sustentável.

\subsection{Conceitos e características da cidade compacta e cidade dispersa}

Para estabelecer a relação entre forma e mobilidade sustentável é relevante explorar as características do grau de compactação urbana. Assim, neste item, abordam-se as questões relacionadas às cidades compacta e dispersa, com o foco em seus conceitos, e são enfatizadas as características mais importantes para potencializar a mobilidade sustentável.

\subsubsection{Cidade compacta}

O processo de urbanização provocou o crescimento das cidades, levando ao desenvolvimento de diferentes formas urbanas. Newton (2000) apresenta cinco tipos de 
configurações: fringe cities, corridor cities, edge cities, compact e dispersed cities ${ }^{11}$. Porém, de acordo com Costa (2007), é em torno da generalização dos termos cidade compacta e dispersa que a discussão ganhou relevância na década de 1980, quando começaram a se estabelecer relações entre a morfologia urbana e consumo energético.

Rueda (2002) define a cidade compacta como sendo aquela que possui características mediterrâneas, densa e que pode ser percorrida a pé ${ }^{12}$, sendo a cidade do pedestre e não do automóvel. É um modelo que permite conceber uma vida social coesa e plataforma econômica competitiva, ao mesmo tempo em que se preservam as áreas naturais. A proximidade dos elementos faz com que haja redução do consumo de energia, tempo e solo, propiciando mecanismos de regulação e controle. Na visão dele, compacidade e diversidade são elementos importantes para manter a complexidade das trocas.

Jenks et al. (1996) consideram que a cidade compacta possui atributos menos nocivos ao meio ambiente, já que são densamente construídas e fazem um uso mais eficiente do solo urbano, evitando o espalhamento da cidade. Jacobs (2009), ao elaborar uma análise crítica sobre as políticas de planejamento modernistas, atacou a tendência herdada da cidade jardim e sugeriu quatro condições necessárias para permitir a diversidade e renovação urbana: (1) uso misto; (2) pequenos blocos ou quadras curtas; (3) combinação de edifícios com estado de conservação variado; e (4) necessidade de concentração, densificação. Esses atributos mencionados remetem à ideia, portanto, da cidade compacta.

A cidade compacta, embora ainda não tenha sido definida de forma clara pelos diversos pesquisadores, apresenta-se como uma aparente solução para o desenvolvimento urbano sustentável. Segundo o Departamento de Prospectiva e Planejamento e Relações Internacionais de Portugal-DPP (2011), é possível apontar alguns elementos caracterizadores que valorizam esse tipo de assentamento:

\footnotetext{
${ }^{11}$ Newton (2000) define as categorias da seguinte maneira - Fringe cities:cidades cujo desenvolvimento ocorre predominantemente na orla urbana; Corridor cities: cidades cujo desenvolvimento ocorre predominantemente ao longo de um corredor linear a partir do núcleo central da cidade, fortemente suportado pelo desenvolvimento do sistema de transportes públicos; Edge cities: cidades que se caracterizam pela ocorrência de crescimento populacional, do emprego e da densidade residencial em nós bem definidos da cidade e simultaneamente pelo desenvolvimento de núcleos de comércio e serviços no exterior da cidade, suportados pelo desenvolvimento da rede viária; Dispersed cities: desenvolvimento contínuo de baixa densidade populacional, com infraestrutura dominada pelo transporte rodoviário; Compact cities: desenvolvimento com altas densidades, possibilidade de melhor estrutura para transporte público.

${ }^{12}$ Rueda (2002) descreve o modelo de cidade compacta e suas características mais importantes. Todavia, sabe-se que nenhuma metrópole pode ser percorrida totalmente a pé. Porém, há um outro viés que deve ser analisado nessa premissa: ao se promoverem elementos estruturadores da forma compacta em uma metrópole, abre-se a possibilidade de favorecer este tipo de deslocamento.
} 
i. Densidade: Níveis máximos de densidade são importantes para diminuir o consumo energético;

ii. Continuidade: Redução dos espaços vazios, assegurando a oferta de infraestrutura, diminuindo a extensão dos percursos e favorecendo os meios de locomoção sustentáveis (o aspecto reduz também o consumo de espaço);

iii. Multifuncionalidade: Coexistência de múltiplas funções urbanas, o que pode permitir a redução dos deslocamentos e aumentar a vitalidade urbana;

iv. Diversidade: Existência de diversidade social, cultural, etária, contribuindo para uma maior urbanidade e menor segregação social.

Segundo Silva (2008), frequentemente o conceito de "cidade compacta" centra-se numa característica fundamental: a densidade. Contudo, não se pode confundir compacidade com densidade: a densidade é apenas um indicador, um dos elementos caracterizadores do modelo de cidade compacta; a densidade urbana resulta do processo de desenho urbano e pode ser influenciada por um conjunto de fatores: dimensões dos lotes (comprimento e largura), padrões de infraestrutura (largura do logradouro público, ruas de acesso, redes de infraestrutura, regulamentações) e a morfologia urbana, conforme ilustra a Figura 9 (ACIOLY E DAVIDSON, 1998). A compacidade pode estar relacionada a densidades maiores, mas este é apenas um viés, visto que a análise da compacidade de determinada área urbana pode ser explorada considerando os atributos morfológicos fundamentados no desenho urbano, como a compacidade axial (Cf. HOLANDA, 2003). A medida pode ser obtida por meio da configuração da malha viária, como demonstram estudos de Medeiros, que utiliza a abordagem da sintaxe espacial (2013).

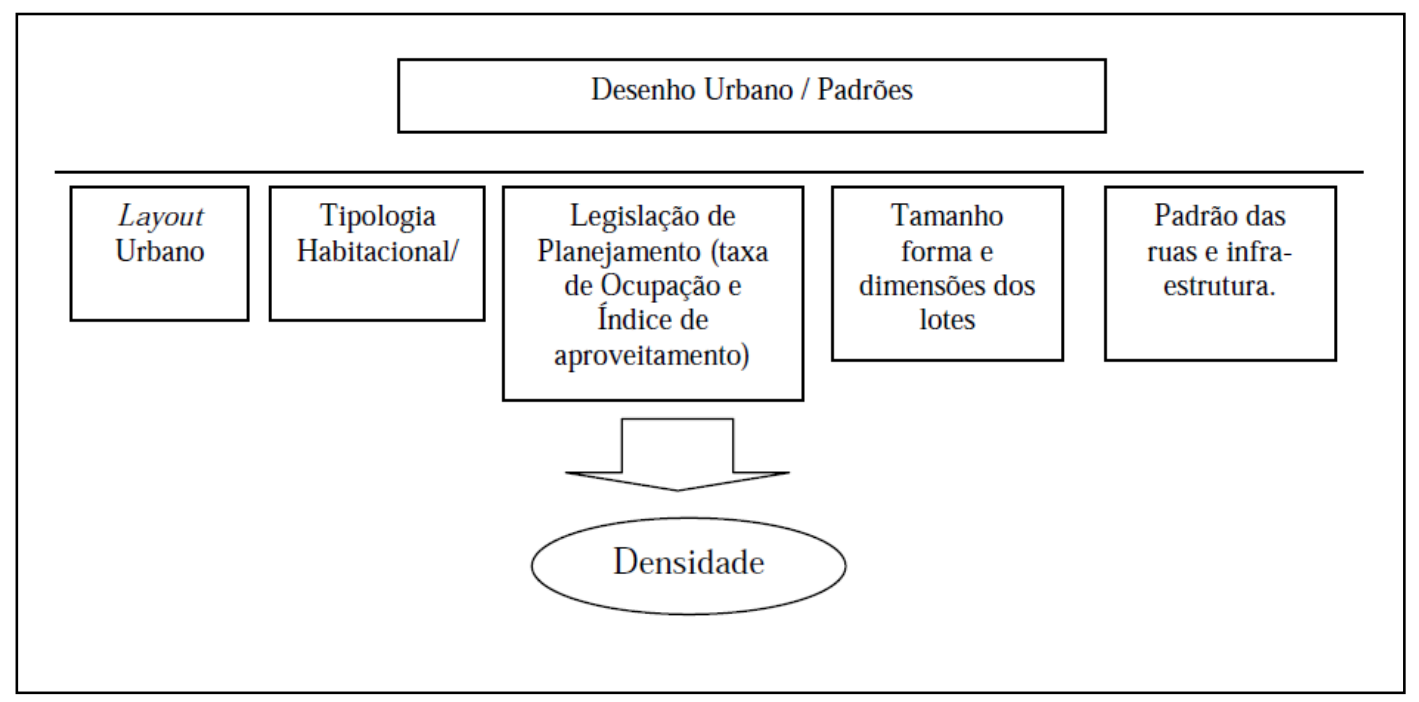

Figura 9: Padrões de Desenho Urbano que influenciam a densidade.

Fonte: Acioly e Davidson, (1988). 
Para Leite e Awad (2012), a cidade compacta é um modelo de desenvolvimento urbano que promove altas densidades de modo qualificado, com adequado planejamento de uso misto do solo urbano, misturando funções urbanas. Gomes (2009) define que a cidade compacta tem como base duas características fundamentais: densidades elevadas e uso de solo diversificado. Juntas, essas duas características traduzem-se em uma intensificação de uso do solo, que poupa área urbanizada, buscando resolver os problemas dentro dos seus próprios limites, evitando a expansão desordenada.

Neuman (2005) argumenta que as características de uma cidade compacta incluem, de modo geral, os seguintes aspectos:

i. Alta densidade residencial e de trabalho;

ii. Diversidade de uso e ocupação do solo, de modo que se reduzam origem e destino das viagens;

iii. Forte interação social e econômica, que pode ser criada por meio de um bom desenho dos espaços públicos;

iv. Desenvolvimento contínuo, evitando-se grandes espaços urbanos vazios e sem utilização;

v. Crescimento urbano contido com limites claramente demarcados, de modo a evitar o aumento do perímetro da cidade;

vi. Sistema de transporte multimodal, privilegiando o uso de transportes não-motorizados, assim como investimentos em grandes estruturas de transporte público;

vii. Alto grau de acessibilidade;

viii. Alto grau de conectividade conforme a interligação de ruas, calçadas e ciclovias, incentivando a população a circular usando transporte não-motorizado;

Arbury (2005) destaca que o modelo de cidade compacta é centrado na densificação e definição de limites ao crescimento urbano, incentivando o desenvolvimento do uso misto do solo urbano e a utilização de transporte público. Jenks e Burgess (2000) enfatizam essa ideia, descrevendo que a cidade compacta é caracterizada por alta densidade, diversidade e delimitação formal. Percebe-se uma preocupação com os aspectos de desenho urbano para obtenção de uma boa forma da cidade.

Jabareen (2006) fez um estudo em que identificou sete variáveis relacionadas com formas urbanas sustentáveis: compacidade, transporte sustentável, densidade, uso misto, diversidade, energia solar e design ecológico. Segundo o pesquisador, a análise da literatura mostra que diferentes combinações dessas variáveis produzem várias formas urbanas 
distintas, agrupáveis em quatro modelos que, entretanto, possuem muita sobreposição em seus conceitos:

i. Desenvolvimento Neotradicional ou Novo Urbanismo: Movimento que surgiu nos Estados Unidos, no início dos anos 1980, voltado para o desenho urbano que defende função mista de habitação e trabalho, com vizinhança diversificada e promoção de bairros que devem ser organizados para serem autônomos, enfatizando os conceitos da forma urbana sustentável e do Transit Oriented Development - TOD (Desenvolvimento orientado ao transporte coletivo);

ii. Contenção Urbana: A expansão urbana emergiu como um padrão de desenvolvimento dominante em grande parte dos Estados Unidos e do mundo, tendo como característica as baixas densidades. $\mathrm{O}$ reconhecimento dos custos de expansão fez com que países desenvolvidos e em desenvolvimento criassem políticas de contenção urbana, impondo restrições geográficas sobre o crescimento urbano. As metas variam muito, mas entre elas podem ser destacadas: preservação dos recursos naturais, aproveitamento de infraestrutura existente, densidades mais elevadas, mistura de usos e promoção do transporte público mais eficiente em áreas já urbanizadas;

iii. Cidade compacta: A ideia de uma cidade compacta inclui várias estratégias que visam criar compacidade e densidade. A compacidade propõe densidade do ambiente construído e intensificação das suas atividades, mistura de usos, além de sistemas de transporte eficientes. Alguns estudiosos defendem o pressuposto de que as cidades compactas oferecem oportunidades para reduzir o consumo de combustível para os deslocamentos, pois o trabalho e as instalações de lazer estão mais próximos. Finalmente, argumenta-se que uma boa qualidade de vida pode ser sustentada, mesmo com elevadas concentrações de pessoas;

iv. Eco-city: Esta abordagem propõe políticas ambientais, sociais e institucionais dirigidas para a gestão de espaços urbanos e engloba propostas urbano-ecológicas para atingir a sustentabilidade. Neste modelo de desenvolvimento urbano, não é apenas a forma física da cidade que importa, mas a maneira como é organizada e gerida também é relevante.

A Tabela 1 apresenta o resultado da pesquisa de Jabareen (2006), na qual é possível observar que a cidade compacta atinge a maior pontuação na classificação geral: as variáveis consideradas sustentáveis estão mais presentes, portanto, na cidade compacta. Como conclusão, o autor enfatiza que ainda não são claros os aspectos ou componentes da forma 
que auxiliam no desenvolvimento sustentável; porém, propõe que a forma ideal seja aquela que priorize densidades elevadas, uso misto e design baseado no transporte sustentável.

Tabela 1: Avaliação da sustentabilidade da forma urbana (Pontuação: 1. Baixo; 2. Moderado; 3. Alto).

\begin{tabular}{lcccc}
\hline $\begin{array}{c}\text { Critérios Relacionados à } \\
\text { Forma }\end{array}$ & $\begin{array}{c}\text { Desenvolvimento } \\
\text { Neotradicional }\end{array}$ & $\begin{array}{c}\text { Cidade } \\
\text { Compacta }\end{array}$ & $\begin{array}{c}\text { Contenção } \\
\text { Urbana }\end{array}$ & $\begin{array}{c}\text { Eco- } \\
\text { city }\end{array}$ \\
\hline Densidade & 2 & 3 & 2 & 2 \\
Diversidade $^{13}$ & 3 & 3 & 2 & 2 \\
Uso misto do solo $_{\text {Compacidade }}$ & 3 & 3 & 2 & 2 \\
Transporte sustentável & 2 & 3 & 2 & 1 \\
Energia solar & 2 & 3 & 2 & 3 \\
Design ecológico & 1 & 1 & 1 & 3 \\
\hline Total & 2 & 1 & 12 & 3 \\
\hline
\end{tabular}

Fonte: Adaptado de Jabarren, 2006.

A defesa do modelo da cidade compacta encontra fortes argumentos quando relacionada à mobilidade urbana sustentável. Para Rogers e Gumuchdjian (2001), a premissa da cidade compacta aciona uma série de oportunidades extras em termos de eficiência, tendo em vista que os atributos da forma urbana compacta parecem induzir um processo que poupa o meio ambiente e acaba promovendo formas mais sustentáveis de mobilidade. Acontece que o cenário criado por altas densidades e uso misto do solo pode permitir maior convivência, reduzindo a necessidade de deslocamentos em automóveis, diminuindo drasticamente a energia utilizada para transporte, trazendo uma série de efeitos positivos: um menor número de carros significa menos congestionamentos e melhor qualidade de ar, fato este que pode estimular as pessoas a caminharem ou andarem de bicicleta em substituição ao veículo particular.

Para Cervero e Kockelman (1997), as variáveis densidade, diversidade de uso e design influenciam a demanda de viagens no espaço urbano - as paisagens urbanas mais atrativas para viagens utilizando-se de transporte público seriam aquelas mais compactas, em que se encontra uma variedade de usos do solo e também são atrativas no seu desenho para os deslocamentos não motorizados. Dependendo da maneira como será implementada a densidade e o uso misto, pode-se também influenciar a promoção de rotas mais atrativas, possibilitando um transporte público mais eficiente. Com isso, têm-se como benefícios a

\footnotetext{
${ }^{13}$ A diversidade mencionada por Jabareen (2006), Jacobs (1961) e DPP (2011) está relacionada com a promoção de outras características urbanas desejáveis, como tipologia de habitações, diferentes densidades, tamanhos variados de terrenos públicos ou privados, etc. Um desenvolvimento diversificado contém mix de uso do espaço, diferentes tipos de construções e habitações e tende colaborar para uma maior diversidade social, cultural, etária, contribuindo para um processo de urbanidade e menor segregação social.
} 
economia do consumo de combustíveis não renováveis (derivados do petróleo) e também a redução da emissão de gás carbônico na atmosfera.

De acordo com o Relatório da Comunidade Europeia (CE, 1996), a morfologia urbana pode influenciar os padrões de mobilidade. Não há unanimidade sobre qual seria a forma urbana mais ou menos sustentável, entretanto, a cidade compacta é assumida como provavelmente a morfologia mais eficaz do ponto de vista energético, promovendo vantagens socioeconômicas e ambientais.

A relação entre a forma urbana e o consumo energético, por exemplo, foi demonstrada por Newman e Kenworthy (1989). Os pesquisadores, para compreenderem a relação entre a dependência do automóvel e a expansão urbana, estabeleceram um vínculo entre o consumo de combustível e a densidade populacional. Os resultados permitiram verificar que à medida que a densidade populacional diminuía, o consumo de combustível ampliava-se (Figura 10). Esses estudos foram desenvolvidos em 32 cidades na América do Norte, Austrália, Europa e Ásia e a conclusão foi de que as cidades mais densas, particularmente na Ásia, utilizavam menos o carro do que as cidades dispersas, como as norte-americanas.

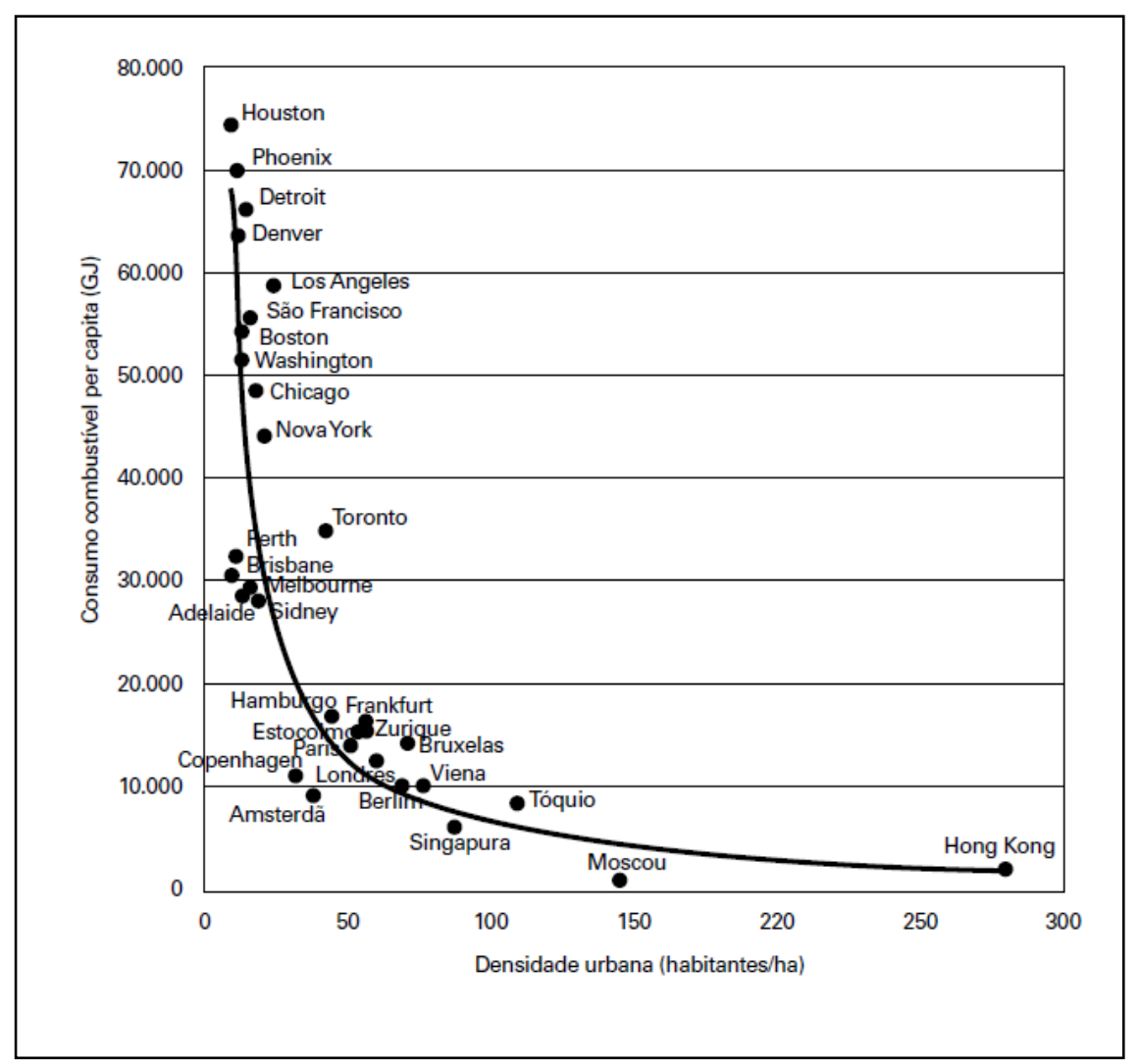

Figura 10: Relação entre consumo de combustível e densidade populacional. Fonte: Newman e Kenworthy, (1989). 
Supõe-se que altas densidades permitam a utilização eficiente de terra disponível, além de garantir que os investimentos públicos sejam mais bem aproveitados, sendo possível conseguir retorno advindo da concentração de pessoas, atividades e unidades construídas.

Porém, é importante estabelecer um nível de densidade aceitável, pois áreas urbanas muito densas podem ser sinônimo de ineficiência econômica, social e ambiental. Acioly e Davidson (1998) argumentam que parece haver um consenso entre especialistas da área de urbanização de que quanto maior a densidade, melhor será a utilização e maximização da infraestrutura e solo urbano. Entretanto, altas densidades podem trazer consequências advindas da saturação das redes de infraestrutura e serviços urbanos, propiciando um meio ambiente superpopuloso e inadequado ao desenvolvimento humano. Portanto, o adensamento urbano tem que vir acompanhado de outras estratégias para que, com isso, o impacto na qualidade de vida das pessoas seja minimizado. A Figura 11 expressa as vantagens e desvantagens de alta ou baixa densidade.

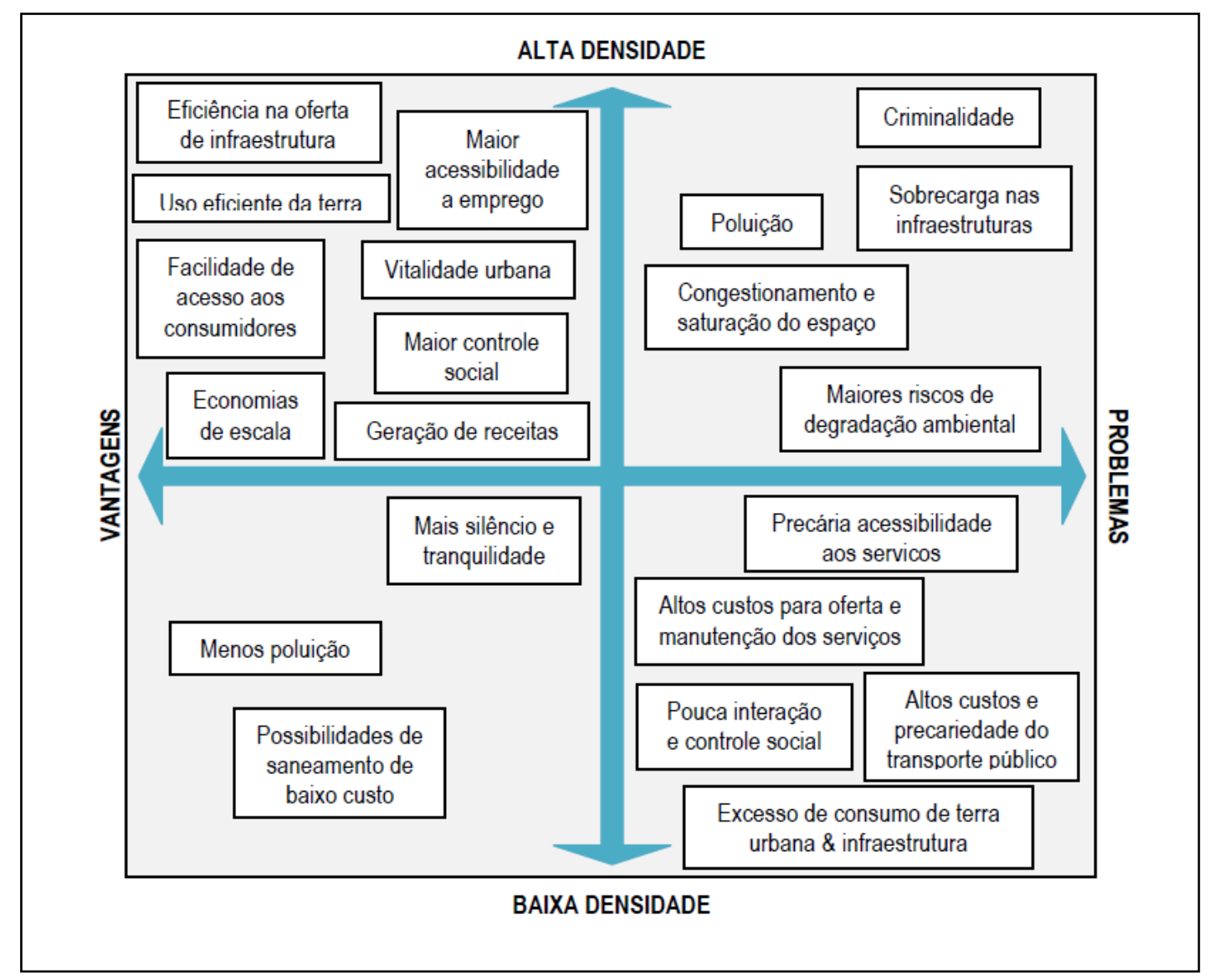

Figura 11: Vantagens e desvantagens de baixas e altas densidades.

Fonte: Acioly e Davidson (1998); Silva, G. J. A. da (2011). 
Litman (2012) estabelece uma série de fatores relacionados a padrões de uso e ocupação do solo que podem afetar o comportamento das viagens e que se aproximam muito dos elementos caracterizadores de uma forma urbana compacta (Quadro 3). Contudo, o autor enfatiza que esses atributos são pouco considerados em estudos de mobilidade urbana.

Quadro 3: Fatores da forma urbana que podem afetar o comportamento de viagens.

\begin{tabular}{l|l}
\hline \multicolumn{2}{c}{ Variáveis da Forma Urbana } \\
\hline Fator & Definição \\
\hline Densidade & As pessoas ou trabalhos por unidade de área de terra (acre ou hectare). \\
\hline Mistura de usos & $\begin{array}{l}\text { Grau que relaciona os usos do solo (residencial, comercial, serviço e } \\
\text { institucional) juntos onde ficam situados. As vezes medido como a relação } \\
\text { de trabalhos e residentes em uma área. }\end{array}$ \\
\hline Acessibilidade & $\begin{array}{l}\text { Local de desenvolvimento relativo a centro urbano regional. Freqüentemente } \\
\text { medido como o número de trabalhos acessível dentro de um tempo de } \\
\text { viagem (por exemplo, 30 minutos). }\end{array}$ \\
\hline Centralidade & $\begin{array}{l}\text { Porção de comercial, emprego, e outras atividades em centros de atividade } \\
\text { principais. }\end{array}$ \\
\hline Conectividade & $\begin{array}{l}\text { Grau que vias e caminhos estão conectados e permitem viagem direta entre } \\
\text { destinos. }\end{array}$ \\
\hline $\begin{array}{l}\text { Gestão da mobilidade } \\
\text { (Provisão e gestão) }\end{array}$ & $\begin{array}{l}\text { Vários programas e estratégias que encorajam padrões de viagem mais } \\
\text { eficientes. Controle de velocidades de tráfico e a favor de modos diferentes e } \\
\text { diferentes atividades. }\end{array}$ \\
\hline $\begin{array}{l}\text { Caminhadas e } \\
\text { condições de Ciclismo }\end{array}$ & $\begin{array}{l}\text { Número de espaços para estacionar por unidade ou hectare construído, e o } \\
\text { grau para o qual eles são estimados e regulados para eficiência. }\end{array}$ \\
\hline $\begin{array}{l}\text { Qualidade de transporte } \\
\text { quáblico e acessibilidade de caminhar e condições de transporte de ciclismo, inclusive a } \\
\text { de bicicleta, e o nível de segurança pedestre. }\end{array}$ & $\begin{array}{l}\text { A qualidade de serviço de trânsito e o grau para os quais destinos são } \\
\text { acessiveis por qualidade no transporte público em uma área. }\end{array}$ \\
\hline Desenho urbano & $\begin{array}{l}\text { O plano e desenho de edifícios, espaços públicos, desenho de ruas e } \\
\text { instalações de estacionamento. }\end{array}$ \\
\hline
\end{tabular}

Fonte: Litman (2012), Fernandes (2008).

Em termos sociais, vários atributos são considerados vantajosos em núcleos mais compactos, como a revitalização dos espaços centrais, o que permite um maior contato social e a promoção da urbanidade ${ }^{14}$. Em termos econômicos, a compacidade reduz custos associados à implantação e à manutenção de infraestrutura básica.

\footnotetext{
${ }^{14}$ Holanda (2003) conceitua urbanidade como uma condição "simultânea ao espaço físico e a comportamentos humanos" e que se caracterizaria pela "minimização de espaços abertos em prol de ocupados na densidade de edificações, na existência do maior número de portas para lugares públicos/jamais paredes cegas, na constituição do espaço, na minimização dos espaços segregados, guetizados, becos sem saída (...)". Holanda agrega à condição de urbanidade outra característica da cidade e que se refere à condição de informalidade, por oposição, a condição de formalidade; ele define a polaridade formalidade/urbanidade como opostos e estabelece um conjunto de novas relações e significados para esses termos que resultam por sugerir que formalidade favoreceria desigualdade enquanto urbanidade favoreceria a democracia.
} 
Entretanto, a urbanização compacta também pode trazer desvantagens quanto a outros elementos, como a formação de ilhas de calor $^{15}$, já que os edifícios e seus usos estão muito próximos. Além disso, segundo Burton (2000), outros efeitos negativos são: menos espaço nas habitações, moradias mais caras, espaços verdes reduzidos e maiores taxas de doenças respiratórias. O desenvolvimento de uso misto, promovendo a proximidade de áreas residenciais e áreas industriais pode ocasionar riscos à saúde.

No que diz respeito à diversidade de uso, uma corrente de pesquisadores entende que, apesar da evidência empírica (Handy, 1992; Ewing et al. 1994; Frank e Pivo, 2005), não está claro se o desenvolvimento do uso misto exerce influência sobre viagens não-motorizadas. Embora as distâncias sejam menores, traduzindo-se em menores percursos, pode surgir o efeito contrário, em um mecanismo compensatório que leve ao aumento do número de viagens. Garcia e Riera (2003), por exemplo, afirmam que os estudos disponíveis não apresentam evidências conclusivas que apoiem a visão de que as cidades compactas realizam determinadas metas ambientais. O Quadro 4 apresenta os principais argumentos a favor e contra a cidade compacta.

Quadro 4: Principais argumentos a favor e contra a cidade compacta:

\begin{tabular}{|c|c|}
\hline Argumento a favor da cidade compacta & $\begin{array}{l}\text { Argumentos contra a cidade } \\
\text { compacta }\end{array}$ \\
\hline $\begin{array}{l}\text { - Consumo de menor espaço para mesma } \\
\text { quantidade de pessoas; } \\
\text { - } \text { Proteção dos recursos naturais; } \\
\text { - } \text { Maior economia nas redes de infraestrutura; } \\
\text { Redução das distâncias a percorrer, fato este } \\
\text { que pode incentivar um menor número e } \\
\text { frequência de viagens pela maior } \\
\text { proximidade domicílio/trabalho, sendo } \\
\text { possível também o acesso ao maior número } \\
\text { de serviços em um perímetro menor. } \\
\text { - Maior eficácia do transporte público; } \\
\text { - Modelo urbano que desestimula a utilização } \\
\text { do carro propiciando soluções mais } \\
\text { amigáveis para mobilidade } \\
\text { - Maior usufruto do espaço público; } \\
\text { - Redução dos fenômenos de exclusão social } \\
\text { As famílias passam a dispor de mais tempo. }\end{array}$ & $\begin{array}{l}\text { - } \text { Quanto maior a densidade maior são os } \\
\text { custos de construção/riscos a saúde; } \\
\text { - Não está comprovada à existência de } \\
\text { economia na oferta de serviços públicos } \\
\text { associados à compactação; } \\
\text { - A utilização do automóvel depende de } \\
\text { vários fatores; } \\
\text { - A escolha do trajeto depende das } \\
\text { preferências } \\
\text { proximidade/tempo é apenas um dos } \\
\text { fatores; } \\
\text { - Maior risco de congestionamento; } \\
\text { As condições das áreas centrais nem } \\
\text { sempre correspondem aos padrões de } \\
\text { conforto; } \\
\text { Diminuto espaço para áreas verdes. }\end{array}$ \\
\hline
\end{tabular}

Fonte: DPP, (2011).

\footnotetext{
${ }^{15}$ Ilhas de calor compreendem a diferença de temperatura entre áreas de grande concentração urbana em relação a outras regiões da cidade menos urbanizadas, podendo ocasionar além de temperatura mais elevadas alterações da umidade, precipitação e dos ventos.
} 
A partir da revisão de literatura sobre cidade compacta, foi possível sintetizar, no Quadro 5 as variáveis mais recorrentes e que melhor caracterizam esse tipo de forma urbana e que podem influenciar na mobilidade urbana.

Quadro 5: Principais características da cidade compacta.

\begin{tabular}{|c|c|c|c|c|c|c|c|c|c|c|}
\hline Características & 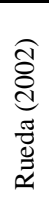 & 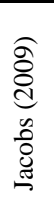 & 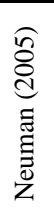 & 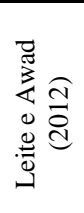 & 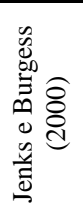 & $\begin{array}{l}\widehat{\Xi} \\
\stackrel{d}{0} \\
\text { مิ }\end{array}$ & 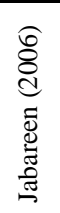 & 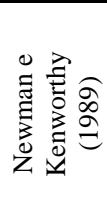 & 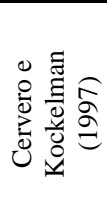 & 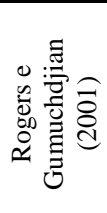 \\
\hline Densidade alta & $\mathrm{x}$ & $\mathrm{x}$ & $\mathrm{x}$ & $\mathrm{x}$ & $\mathrm{x}$ & $\mathrm{x}$ & $\mathrm{x}$ & $\mathrm{x}$ & $\mathrm{x}$ & $\mathrm{x}$ \\
\hline $\begin{array}{c}\text { Uso misto/ } \\
\text { Multifuncionalidade }\end{array}$ & $\mathrm{x}$ & $\mathrm{X}$ & $\mathrm{X}$ & $\mathrm{x}$ & $\mathrm{x}$ & $\mathrm{x}$ & $\mathrm{x}$ & $\mathrm{x}$ & $\mathrm{x}$ & $\mathrm{x}$ \\
\hline $\begin{array}{c}\text { Continuidade (redução de } \\
\text { vazios) }\end{array}$ & & & $\mathrm{X}$ & & & $\mathrm{X}$ & & & & \\
\hline $\begin{array}{c}\text { Características do desenho } \\
\text { urbano } \\
\text { (conectividade/acessibilidade) }\end{array}$ & & & $X$ & & & & & & $\mathrm{x}$ & \\
\hline
\end{tabular}

Dentro do que foi discutido sobre as características da cidade compacta, assume-se que os aspectos positivos oriundos do modelo se sobrepõem à dúvida de sua eficácia; portanto, os atributos resultantes desta forma favorecem as condições de mobilidade urbana. A cidade compacta oferece uma estrutura que facilita a ordenação pela proximidade, auxilia a concepção de transportes mais inteligentes, já que o transporte público pode ser mais racional e eficiente e as distâncias podem ser facilmente alcançadas a pé ou de bicicleta.

\subsubsection{Cidade dispersa}

Segundo Rogers e Gumuchdjian (2001), a cidade dispersa, fundamentada no automóvel, reinventou o modelo urbano conhecido pela humanidade até o século XIX. A transformação no padrão da forma urbana compacta para dispersa resultou de um processo histórico explicado por fatores de diversas ordens, com ênfase na evolução de novas tecnologias em transporte e também como resposta às cidades industriais do século XIX, que passaram a ser insalubres em função da superpopulação e da falta de infraestrutura adequada. "As cidades industriais tornaram-se verdadeiros infernos: sofriam com superpopulação, pobreza e problemas com a saúde; canalizações a céu aberto espalhavam a cólera e febre" (ROGERS E GUMUCHDJIAN,2001). 
Como resultado, a expectativa de vida em muitas cidades industriais inglesas diminuiu bastante. Essas desigualdades básicas levaram pensadores como Ebenezer Howard, em 1898, e Patrick Abercrombie, em 1944, a proporem uma menor concentração de habitantes em ambientes menos densos e mais verdes: o produto foram as cidades-jardins e as New Towns.

Outra resposta a esses problemas foi apresentada pela Carta de Atenas (1933), síntese do pensamento modernista, cujos fundamentos podem ser sintetizados em: separação de funções (habitação, trabalho, lazer e circulação), existência de amplas praças e complexos urbanísticos uniformes. O movimento moderno no urbanismo não mediu até que ponto o nível de dispersão poderia ocorrer sem criar outros tipos de problemas no espaço urbano e estabeleceu seus princípios como verdade absoluta para todos os tipos de urbanização.

A partir do século XIX, as cidades expandiram-se de forma descontínua e irregular gerando uma estrutura determinada por uma rede rodoviária significativamente dependente do automóvel particular. Associado a isto, um conjunto de fatores de ordem econômica, social e demográfica influenciou no desenvolvimento da forma dispersa.

Em termos de conceituação, segundo Ewing (1997), a urbanização dispersa baseia-se na expansão urbana, com vazios urbanos intermediários, baixas densidades e crescimento da mancha urbana, sendo um tipo urbano característico das cidades americanas. A principal feição da cidade dispersa é uma forte pressão de expansão sobre os limites urbanos, que tem de ser suportada pelas redes de transporte. Nas cidades de países em desenvolvimento, esta urbanização, além de possuir densidade declinante à medida que se afasta do centro, também se caracteriza pela falta de serviços e espaços públicos de qualidade. Neste modelo urbano, o automóvel particular é o modo priorizado. A forma urbana dispersa caracteriza-se pelo desenvolvimento descontínuo e linear que consome vastas áreas de baixa densidade e de uso singular do solo (espaços dormitórios) (GOMES, 2009; COSTA, 2007).

Alves (2011) define que a ocupação dispersa consiste no alastramento da ocupação urbana para fora dos limites formais da cidade, confundindo as fronteiras entre urbano e rural. De acordo com Mancini (2008), o modelo de urbanização dispersa, também chamado na literatura internacional de urban sprawl ${ }^{16}$,vem sendo estudado considerando diferentes abordagens e trata-se de um fenômeno que ocorre em escala mundial, sob ritmos e caminhos desiguais. O modelo conduz a uma nova realidade espacial que evidencia formas urbanas mais complexas, baseadas em padrões de urbanização difusos e densidade declinante.

\footnotetext{
${ }^{16}$ O termo Urban Sprawl surgiu na década de 1960, nos Estado Unidos para expressar o crescimento desordenado das aglomerações urbanas norte-americanas. Trata-se de um conceito em construção e que encontra outras denominações na literatura: ocupação dispersa, urbanização extensiva e cidade dispersa.
} 
Para Silva e Romero (2011), o urbanismo disperso gera problemas ambientais, face ao espalhamento da cidade sobre a paisagem natural, apropriando-se dos recursos naturais, exigindo um intenso uso do transporte de pessoas e bens. $\mathrm{O}$ desenho representado na Figura 12 demonstra que a dispersão urbana e o zoneamento rígido induzem à utilização do automóvel particular, já que as atividades se encontram desarticuladas no espaço urbano, enquanto que os núcleos compactos tendem a integrar as atividades de uso e ocupação do solo, diminuindo as distâncias e fomentando os meios de transporte não-motorizados.

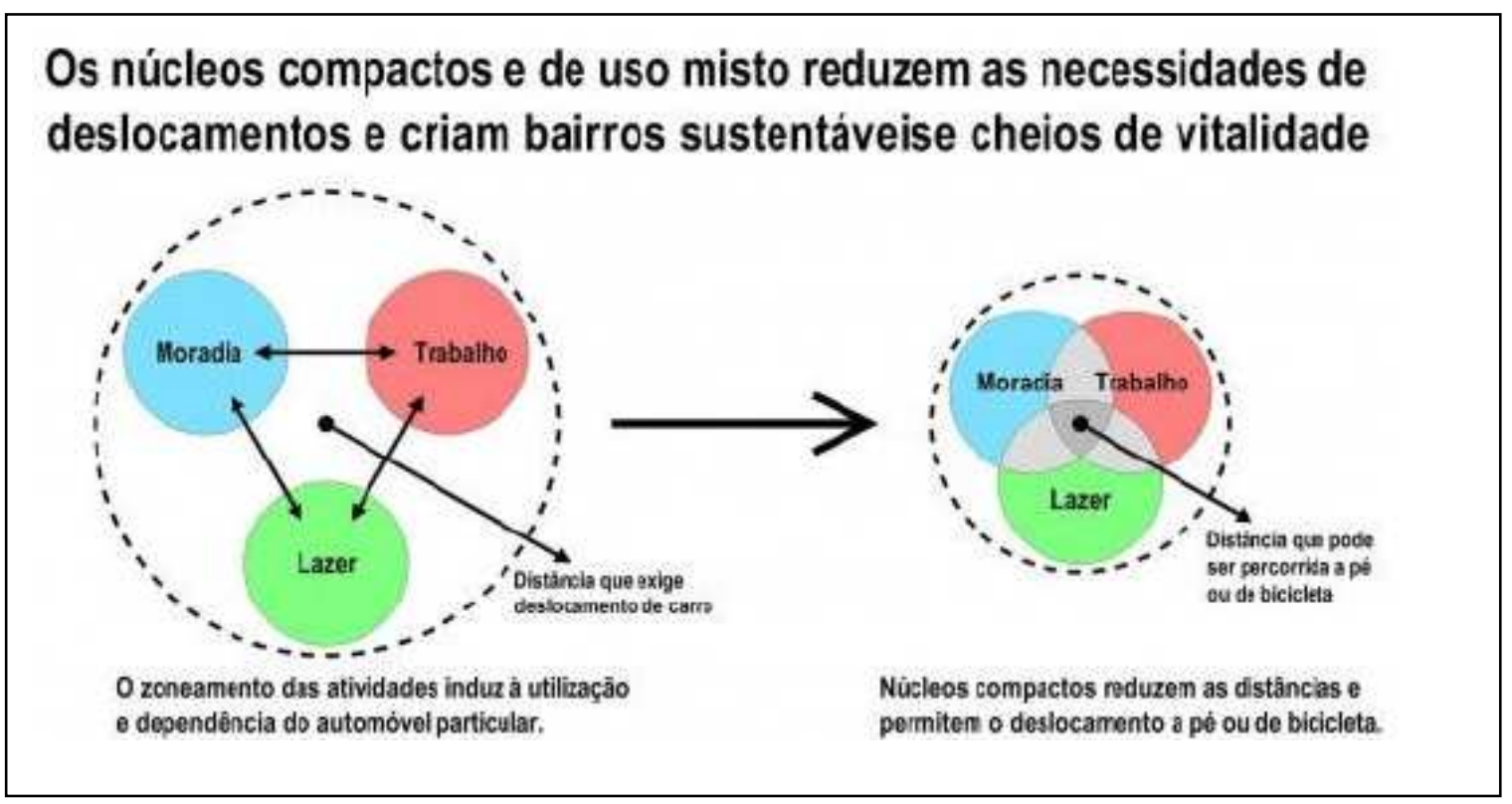

Figura 12: Esquema da relação entre núcleos compactos/dispersos e a redução de deslocamento. Fonte: Silva e Romero, (2011); adaptado de Rogers, (2001).

Silva (2008) considera que os problemas gerados por uma urbanização expansiva são os seguintes: consumo excessivo do solo, congestionamentos, elevado consumo energético, aumento da poluição, elevados custos em infraestrutura e ineficiência no fornecimento de infraestrutura adequada, além de segregação socioeconômica e exclusão social. De modo geral, o formato urbano disperso separa socialmente a população, impondo a locomoção em grandes distâncias e o aumento de energia, o que gera prejuízos ambientais e econômicos.

A cidade dispersa pode, em algumas circunstâncias, ser melhor em termos estéticos e viabilizadora de maior contato com a natureza. No entanto, nela há pouca interação social e se exerce maior pressão sobre os recursos naturais, além de trazer prejuízos à mobilidade urbana devido às distâncias elevadas.

O debate sobre a sustentabilidade desse modelo urbano discute o processo de deterioração que acabam por sofrer os centros urbanos e a segregação sócio espacial que resulta. Além disso, consideram-se as implicações em razão da dependência do transporte 
individual sobre a mobilidade das atividades econômicas e dos locais de emprego e os aspectos energéticos e ambientais que decorrem dos deslocamentos diários casa-trabalhocasa. Outra vertente lembra que a necessária criação de novas centralidades exerce pressão sobre o mercado imobiliário (ACIOLY E DAVIDSON, 1998). O Quadro 6 contém algumas características e fatores que favorecem a dispersão.

Quadro 6: Características e fatores que favorecem a dispersão.

\begin{tabular}{l|l}
\hline $\begin{array}{l}\text { Econômicos (macro e } \\
\text { micro) }\end{array}$ & $\begin{array}{l}\text { Crescimento econômico, disponibilidade e preço do solo, } \\
\text { globalização. }\end{array}$ \\
\hline $\begin{array}{l}\text { Demográficos } \\
\text { Características dos } \\
\text { centros das cidades }\end{array}$ & $\begin{array}{l}\text { Crescimento da população. } \\
\text { Ruído, insegurança, tráfego, ausência de áreas verdes, qualidade } \\
\text { ruim dos espaços públicos. } \\
\text { Pais espaço, áreas distantes do centro. }\end{array}$ \\
$\begin{array}{l}\text { Transporte } \\
\text { Automónel privado, desenho viário baseado em autoestradas, } \\
\text { aparente disponibilidade de energia. } \\
\text { Regulamentação } \\
\text { Insuficiente ou inadequado planejamento do território, fraca } \\
\text { capacidade de implementação de planos, ausência de } \\
\text { coordenação e colaboração. } \\
\text { Culturais, sociais. }\end{array}$ \\
\hline Outros
\end{tabular}

O relatório publicado pela European Environment Agency - EEA (2006) apresenta uma extensa lista de implicações relativas aos impactos ambientais e socioeconômicos que resultam do fenômeno Urban Sprawl. No que diz respeito aos impactos ambientais, o relatório destaca que as implicações em nível de consumo de solo são alarmantes, uma vez que a contínua ocupação do território não é um processo passível de reconversão. Essa situação é preocupante, porque as intervenções ou alterações na estrutura do solo podem implicar em perturbações, como, por exemplo, a perda de permeabilidade de solo que pode afetar o sistema hidrológico e possíveis interferências na estabilidade dos terrenos. O aumento da área de solo urbanizada resulta em maior consumo energético, sobretudo dos combustíveis fósseis, devido ao tráfego intenso e longas distâncias, levando ao aumento da emissão de gases. A ocupação dispersa do território tem impacto direto ainda sobre a diminuição de solo agrícola produtivo, devido à fragmentação do espaço; além disso, pequenas áreas agrícolas próximas às áreas urbanizadas tendem a ser abandonadas, na expectativa de serem igualmente urbanizadas. Com relação aos impactos socioeconômicos, o relatório aponta para uma tendência de segregação funcional, com predomínio de áreas residenciais, sendo que outros usos podem coexistir, mas quase sempre numa lógica aleatória e independente entre si.

No contraponto da discussão sobre a falta de sustentabilidade de modelos urbanos considerados dispersos, tem-se a corrente dos que os julgam benéficos. Os defensores dessa 
teoria (Echenique, 2001; Richardson et al. 2001) acreditam que o adensamento pode exacerbar os problemas, criando espaços indesejáveis e não geram necessariamente menos deslocamentos. Esses pesquisadores ponderam ainda sobre a frequência das viagens não estar diretamente relacionada à densidade residencial e sim aos fatores socioeconômicos, como renda e localização dos empregos. A ocupação de áreas periféricas, associada a uma política de uso e ocupação do solo, poderia trazer mais vantagens, como: moradias mais espaçosas, descentralização das atividades permitindo melhor acessibilidade e liberdade de escolha, já que as áreas centrais tendem a ser mais caras (aluguel).

A tendência ao modelo urbano disperso gera uma disputa pelas áreas urbanas periféricas, onde se instalam habitações de interesse social para pessoas de baixa renda e, também, por outro segmento social, que considera que este tipo de forma urbana pode trazer alguns atrativos, como viver em zonas com áreas verdes mais amplas e distantes do centro da cidade, pois são menos poluídas e podem aparentar maior segurança, mesmo que para isso tenham que vencer grandes distâncias utilizando o transporte individual. As cidades norteamericanas são sempre lembradas como exemplos típicos deste tipo de urbanização de baixa densidade e crescimento linear.

Neste ponto, importa remeter à ideia de segregação "voluntária" e "involuntária". A primeira refere-se àquela em que o indivíduo ou uma classe de indivíduos busca, por iniciativa própria, localizar-se próximo a outras pessoas de sua classe, tradicionalmente em locais distantes do centro urbano. A involuntária, ao contrário, é aquela em que os indivíduos são segregados contra a sua vontade, por falta de opção. Ambos são as duas faces de uma mesma moeda: à medida que uma acontece, a outra também acaba ocorrendo (SABOYA, 2009).

A análise da literatura sugere o cálculo para o índice de dispersão urbana (Cf. Bertaud e Malpezzi, 1999, 2003; Ojima, 2007). Bertaud e Malpezzi (1999; 2003) propõem o cálculo do índice de dispersão relacionando a forma das cidades às distâncias ao centro de comércio e serviços $(\mathrm{CCS})^{17}$. Ribeiro (2008), utilizando o método proposto, calculou o índice de dispersão para cidades brasileiras. Apontou em seus estudos que existe uma diferença entre cidades descentralizadas e cidades dispersas; no primeiro caso, as cidades são policêntricas, permitindo a geração de empregos e atração das pessoas para diferentes pontos da cidade. Nas

\footnotetext{
${ }^{17}$ Centro de Comércio e Serviços (CCS) ou na língua inglesa Central Business District (CBD), deve ser compreendido como o local da cidade onde se concentram as atividades de comércio, serviços, administração pública e circulação de pessoas.
} 
cidades dispersas, a população está distante do CCS, contribuindo para o aumento do uso e custo do transporte e a renda tende a diminuir à medida que se afasta do centro.

Ojima (2007), por outro lado, considerou para o cálculo do indicador sintético da dispersão urbana as dimensões sociais e espaciais, utilizando as variáveis densidade, fragmentação, linearidade e centralidade. O autor calculou o indicador para 37 cidades brasileiras e montou um ranking ${ }^{18}$. Conclui, em seus estudos, que o indicador conseguiu captar as dimensões da dispersão urbana, apesar de não ter contemplado todas as dimensões possíveis para análise da forma de expansão urbana. Outra conclusão ao cruzar os dados de dispersão com dados disponibilizados pelo IBGE aponta que quanto mais dispersa a área urbana, maior a proporção de domicílios com pelo menos um automóvel de uso particular. Ojima ressalta que esse resultado vem ao encontro do que aponta a literatura sobre o tema: "se uma região possui dispersão urbana maior, a necessidade de deslocamentos e meios de transporte também é maior (OJIMA, 2007)”.

O Quadro 7 contém um resumo sobre as características da cidade dispersa no que diz respeito à forma urbana, segundo o foco abordado nos estudos dos autores citados:

Quadro 7: Principais características da cidade dispersa.

\begin{tabular}{|c|c|c|c|c|c|}
\hline Características & 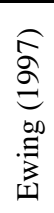 & 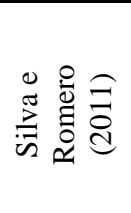 & 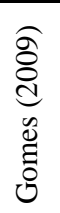 & 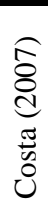 & 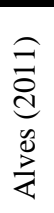 \\
\hline Densidade baixa & $\mathrm{x}$ & & $\mathrm{x}$ & $\mathrm{x}$ & \\
\hline $\begin{array}{l}\text { Zoneamento rígido (uso } \\
\text { singular do solo) }\end{array}$ & $\mathrm{x}$ & $\mathrm{x}$ & & & \\
\hline $\begin{array}{c}\text { Grandes espaços vazios } \\
\text { (desenvolvimento } \\
\text { descontínuo e linear) }\end{array}$ & $\mathrm{x}$ & $\mathrm{x}$ & $\mathrm{x}$ & $\mathrm{x}$ & \\
\hline Expansão urbana & $\mathrm{x}$ & $\mathrm{x}$ & $\mathrm{x}$ & $\mathrm{x}$ & $\mathrm{x}$ \\
\hline
\end{tabular}

Diante do exposto e das considerações sobre as principais características da cidade dispersa, percebe-se que os atributos desse modelo podem causar prejuízos à sustentabilidade urbana, principalmente nas questões relativas à mobilidade. Em função disso, neste estudo, defende-se a hipótese de que a compacidade tem atributos positivos que podem auxiliar na

\footnotetext{
${ }^{18}$ As cidades foram classificadas quanto ao indicador de dispersão: da mais dispersa a menos dispersa (OJIMA, 2007, p.130).
} 
obtenção de uma mobilidade sustentável, fundamentada no alto custo que a sociedade, baseada no transporte individual, tem que pagar: aumento do consumo de espaço, aumento das distâncias a serem percorridas, tempo perdido em função dos congestionamentos, ampliação de infraestrutura para absorver o crescimento da frota de veículos. Todos esses fatores somados, resultam em piora da qualidade de vida das pessoas.

Assim, tanto pelo lado dos parâmetros urbanísticos que fundamentam a cidade compacta como por aqueles que não são desejáveis e que caracterizam a cidade dispersa, é possível pensar numa sistematização que nos leve a subsidiar o planejamento e desenho urbano sustentável.

\subsection{Atributos da forma urbana que podem potencializar a mobilidade urbana sustentável}

A discussão anterior remete a uma pergunta: que atributos da forma urbana podem favorecer a mobilidade sustentável? A revisão teórica procedida permite o ordenamento de um conjunto de características que podem potencializar a mobilidade numa estrutura urbana e que, mais a frente, ainda neste item, serão destacadas com vistas à identificação de sua efetividade por meio de estudo de caso. Entretanto alguns aspectos precisam ser consistentemente definidos para o delineamento da pesquisa:

i. Uma vez apresentado o conceito sobre mobilidade urbana sustentável, cabe destacar que existem diversas variáveis que podem levar a esse estado. Assume-se aqui que a obtenção da mobilidade sustentável depende da articulação de uma série de elementos, sejam eles relacionados à forma urbana, aos elementos de transporte e à circulação, às questões socioeconômicas e às de preferências pessoais. Mesmo ciente dessa amplitude de variáveis, esta pesquisa tem como foco analisar, a partir do contexto da forma urbana, sua relação com a mobilidade sustentável. Em função disso, as variáveis selecionadas neste estudo terão como foco essa premissa;

ii. Não existem cidades totalmente compactas ou dispersas: as cidades brasileiras no geral, mesclam atributos nos dois polos. O fato aponta que há realidades muito distintas dentro de um mesmo território. Em razão disso, os conceitos de cidade compacta e dispersa servem apenas para auxiliar na escolha das variáveis que influenciam para potencializar a mobilidade sustentável;

iii. A ação de criar núcleos mais compactos, por si só, não resolve o problema da sustentabilidade ambiental, mas, com relação à mobilidade urbana sustentável, parece 
produzir efeitos mais positivos. A promoção de características da forma urbana compacta em determinada área, no sentido de fomentar a mobilidade urbana sustentável, deve vir acompanhada de outras estratégias, como, por exemplo, um eficiente sistema de transporte público que conecte núcleos adensados, desenho urbano que permita a conectividade entre as vias, criando uma malha urbana mais acessível;

iv. Por fim, de acordo com o escopo teórico a respeito das cidades compactas e dispersas, percebe-se que algumas variáveis aparecem como instrumentos que capturam as dimensões do ambiente construído ou características físicas do urbano que podem influenciar em padrões de mobilidade sustentável. Essas variáveis serão testadas por meio de um estudo de caso em área urbana, utilizando um Procedimento de Análise Espacial específico.

O Quadro 8 sintetiza as principais características mencionadas nos itens 2.5.1 e 2.5.2. Na sequência, o Quadro 9 contém um resumo de como esses elementos se relacionam à mobilidade urbana sustentável:

Quadro 8: Principais características da cidade compacta e dispersa de acordo com a revisão de literatura e que podem impactar a mobilidade urbana.

\begin{tabular}{c}
\hline $\begin{array}{c}\text { Principais características da forma urbana } \\
\text { compacta/dispersa que podem influenciar a } \\
\text { mobilidade urbana sustentável }\end{array}$ \\
\hline Densidade \\
\hline $\begin{array}{c}\text { Características do uso do solo urbano } \\
\text { (uso misto, uso singular) }\end{array}$ \\
\hline $\begin{array}{c}\text { Característica do desenho urbano } \\
\text { (conectividade/acessibilidade) }\end{array}$ \\
Continuidade \\
\hline
\end{tabular}


Quadro 9: Síntese dos fatores relacionados à forma urbana compacta e sua influência em padrões de mobilidade urbana sustentável.

\begin{tabular}{c|l}
$\begin{array}{c}\text { Fatores relacionados à forma } \\
\text { urbana compacta }\end{array}$ & \multicolumn{1}{|c}{ Influência na Mobilidade Urbana Sustentável } \\
\hline Densidade & $\begin{array}{l}\text { A densidade é influenciada pelos índices urbanísticos (taxa de } \\
\text { ocupação, índices de aproveitamento, gabarito). Criar uma } \\
\text { diversidade urbana de tipologia de habitações, diferentes } \\
\text { densidades, tamanhos diferentes de terrenos públicos ou } \\
\text { privados implicaria em menor segregação espacial e poderia } \\
\text { também influenciar a mobilidade urbana porque é um atributo } \\
\text { condicionador da densidade. O aumento da densidade pode } \\
\text { auxiliar na redução das viagens por veículo se planejado junto } \\
\text { com a oferta de transporte público e uso misto do solo. Baixa } \\
\text { densidade impacta de forma negativa a mobilidade urbana. }\end{array}$ \\
\hline $\begin{array}{c}\text { Características do uso do solo urbano } \\
\text { (uso misto, multifuncionalidade/uso } \\
\text { singular) }\end{array}$ & $\begin{array}{l}\text { Promover o uso misto e maior proximidade entre as diversas } \\
\text { atividades pode reduzir a necessidade do automóvel e facilitar } \\
\text { na construção de uma rede transporte mais eficiente e } \\
\text { integrada. Uso singular ou zoneamento rígido pode gerar mais } \\
\text { deslocamentos no tecido urbano, impactando de maneira } \\
\text { negativa na mobilidade urbana. }\end{array}$ \\
\hline Continuidade & $\begin{array}{l}\text { Tendência à limitação do processo de expansão urbana. } \\
\text { Crescimento próximo ao centro. Preenchimento dos espaços } \\
\text { vazios, requalificação dos espaços degradados. A expansão } \\
\text { das cidades é um fator que gera mais viagens de automóvel. }\end{array}$ \\
\hline $\begin{array}{c}\text { As características do desenho urbano podem auxiliar na } \\
\text { redução de viagens de automóvel, principalmente se o mesmo } \\
\text { permitir articulação com o serviço de transporte público por } \\
\text { meio de melhor conectividade e acessibilidade entre ruas, } \\
\text { calçadas e ciclovias. Dependendo da concepção do desenho } \\
\text { urbano, pode-se atribuir em determinadas áreas urbanas uma } \\
\text { maior ou menor utilização para os transportes não- } \\
\text { motorizados ou transporte público, reduzindo a dependência } \\
\text { do automóvel. }\end{array}$ \\
\hline
\end{tabular}

A revisão de literatura, ao confirmar a importância dos elementos definidores da forma urbana para alcance da mobilidade, leva-nos à compreensão de que a obtenção da mobilidade sustentável depende ainda da articulação de uma série de elementos relativos ao sistema de transporte e circulação. Esse entendimento remete à importância da identificação dos indicadores que são utilizados na área de transportes para consideração complementar às características da forma urbana quando da análise da estrutura urbana que será utilizada no estudo de caso da presente pesquisa. 


\subsubsection{Indicadores de Mobilidade Urbana Sustentável}

Indicadores são selecionados e construídos a partir de dados de origem diversa para condensar informações complexas de forma simplificada, proporcionando uma mensagem significativa sobre o sistema de interesse (GUDMUNDSSON, 2004).

Os indicadores provêm somente uma indicação da condição ou estado de um determinado fenômeno. Um único indicador pode não fornecer um retrato completo de uma dada situação, sendo usual um conjunto de indicadores para caracterizar aspectos de um problema (COSTA, 2008). A junção de dois ou mais indicadores representa um índice.

De modo geral, os indicadores podem ser úteis na compreensão dos problemas e na determinação de ações mais pontuais, pois fornecem uma imagem representativa do objeto, reduzem a complexidade da análise e ainda podem ser moldados de maneira que se possa acompanhar as mudanças ou tendências do fenômeno estudado, adquirindo capacidade de resposta às mudanças.

Vários programas de pesquisas internacionais e nacionais tratam de indicadores de mobilidade urbana sustentável. Os trabalhos desenvolvidos por esses programas de pesquisa refletem o interesse específico do local onde a pesquisa foi desenvolvida, conforme ilustra o Quadro 10.

Quadro 10: Pesquisas Nacionais e Internacionais sobre Indicadores de Mobilidade Urbana.

\begin{tabular}{|c|c|c|}
\hline \multicolumn{2}{|r|}{$\begin{array}{l}\text { Programas de } \\
\text { Pesquisa }\end{array}$} & Características/objetivo do Programa \\
\hline \multirow{8}{*}{ 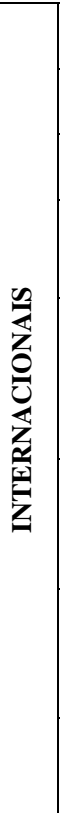 } & SUMMA & $\begin{array}{l}\text { Sustainable Mobility, Policy Measures and Assessment - objetiva definir transporte e mobilidade sustentáveis e } \\
\text { operacionalizar a definição selecionando indicadores para sua monitoração. }\end{array}$ \\
\hline & CST & $\begin{array}{l}\text { Centro de Transportes Sustentável do Canadá - o projeto identificou } 14 \text { indicadores que formam um conjunto } \\
\text { de indicadores de desempenho do transporte sustentável com ênfase na dimensão ambiental da mobilidade. }\end{array}$ \\
\hline & VTPI & $\begin{array}{l}\text { Victoria Transport Police Institute - desenvolvimento de soluções inovadoras para sistema de transporte, onde } \\
\text { se destacam os esforços na pesquisa e avaliação dos indicadores de mobilidade mais representativos. }\end{array}$ \\
\hline & TRANSFORUM & $\begin{array}{l}\text { Scientific Forum on Transport Forect - fórum de investigação constituído para avaliar os projetos da União } \\
\text { Europeia com foco no desenvolvimento de modelos e indicadores capazes de combinar as condições sociais, } \\
\text { econômicas e ambientais para o desenvolvimento sustentável. }\end{array}$ \\
\hline & TRANSPLUS & $\begin{array}{l}\text { Transport Planning, Land Use Land Sustainability- o objetivo desta pesquisa foi identificar as melhores } \\
\text { práticas na organização das políticas de transporte e uso do solo para um padrão sustentável da mobilidade nas } \\
\text { cidades e regiões da Europa, promovendo melhorias econômicas, sociais e ambientais. Como resultado deste } \\
\text { projeto foram identificados indicadores de uso do solo e transporte e modelos de análise, além do } \\
\text { desenvolvimento de estudos de caso em dez cidades na Europa. }\end{array}$ \\
\hline & PROPOLIS & $\begin{array}{l}\text { Planning and Research of Policies for Land Use and Transport for Increasing Urban Sustainbaility - investiga, } \\
\text { desenvolve e analisa metodologias integradas, incluindo uso do solo, modelagem de transporte e meio ambiente } \\
\text { e indicadores de avaliação, com a finalidade de definir estratégias sustentáveis em áreas urbanas e demonstrar } \\
\text { seus efeitos nas cidades europeias. }\end{array}$ \\
\hline & PROSPECTS & $\begin{array}{l}\text { Procedures for Recommending Optimal Sustainable Planning European City Transport Systems - o objetivo } \\
\text { deste projeto foi desenvolver um guia para que as cidades pudessem gerar estratégias de desenvolvimento de } \\
\text { uso do solo e transporte de forma otimizada para alcançar a sustentabilidade. Um dos resultados deste projeto } \\
\text { foi a definição de indicadores relacionados com as metas a serem alcançadas. }\end{array}$ \\
\hline & SCATTER & $\begin{array}{l}\text { Sprawling Cities and Transport: From Evaluation to Recommendation - a pesquisa tem como objetivo estudar } \\
\text { as causas e consequências do espalhamento urbano, avaliar medidas para reduzi-lo e auxiliar as cidades no } \\
\text { desenvolvimento de políticas afins. }\end{array}$ \\
\hline & IQVU-BR & Índice de qualidade de vida urbana desenvolvido por Nahas (2005), e inclui o tema transporte e mobilidade. \\
\hline 至 & $\begin{array}{l}\text { IMUS } \\
(2008)\end{array}$ & $\begin{array}{l}\text { Índice de mobilidade urbana sustentável (IMUS) desenvolvido por Costa (2008). Com bases nesses indicadores } \\
\text { é possível avaliar e monitorar a mobilidade urbana medindo as condições atuais de modo que se possam } \\
\text { estabelecer estratégias com vista a mobilidade urbana sustentável. }\end{array}$ \\
\hline
\end{tabular}




\begin{tabular}{|c|c|}
\hline $\begin{array}{l}\text { Programas de } \\
\text { Pesquisa }\end{array}$ & Características/objetivo do Programa \\
\hline $\begin{array}{l}\text { IMUS Campos e } \\
\text { Ramos (2005) }\end{array}$ & $\begin{array}{l}\text { Os pesquisadores Campos e Ramos (2005) definiram um índice de mobilidade sustentável composto por um } \\
\text { conjunto de indicadores que traduzem questões associadas ao uso e ocupação do solo e ao sistema de } \\
\text { transporte. }\end{array}$ \\
\hline ANTP & $\begin{array}{l}\text { Associação Nacional dos Transportes Públicos - a ANTP organiza um relatório anual sobre a mobilidade } \\
\text { urbana no Brasil (Sistema de Informação da Mobilidade Urbana); para tanto, avalia um conjunto de indicadores } \\
\text { com dados agregados para municípios com mais de } 60.000 \text { habitantes. }\end{array}$ \\
\hline IATP & $\begin{array}{l}\text { Índice de adequação do transporte público desenvolvido por Gomide (Gomide et al, 2004) e que trata } \\
\text { especificamente da questão do transporte público. }\end{array}$ \\
\hline PLANUTS & $\begin{array}{l}\text { Planejamento Urbano e de Transportes Integrado e Sustentável - ferramenta computacional para elaborar e } \\
\text { monitorar planos diretores de mobilidade baseada nos indicadores desenvolvidos por Costa (2008) } \\
\text { desenvolvido por Magagnim (2008). }\end{array}$ \\
\hline
\end{tabular}

Fontes: Campos e Ramos (2005), Costa (2008), Machado (2010).

O sistema de indicadores de mobilidade urbana sustentável desenvolvido por Costa (2008) tem sido um dos trabalhos mais utilizados em pesquisas acadêmicas no Brasil. Foram calculados, até o momento, o Índice de Mobilidade Urbana Sustentável (IMUS) de Brasília, Curitiba, São Paulo, Vitória, Goiânia e também de algumas cidades que não são capitais, mas que são populosas (municípios de médio porte) como São Carlos, Uberlândia e Juazeiro do Norte. A elaboração do índice, partiu da análise de indicadores propostos por programas nacionais e internacionais (Tabela 2) e do resultado de workshops promovidos pela Secretaria de Mobilidade (SeMob), ligada ao Ministério das Cidades, envolvendo onze regiões metropolitanas e aglomerações urbanas brasileiras: Goiânia, Palmas, Recife, Fortaleza, Manaus, Maceió, Aracaju, Belo Horizonte, Vitória, Florianópolis e Porto Alegre.

O cálculo do IMUS foi desenvolvido por meio de metodologia multicritério de apoio à decisão, em que foram selecionados 87 indicadores em uma hierarquia que agrega 37 temas e 9 domínios, conforme consta no Anexo A. Além da hierarquia de critérios, o IMUS utiliza um sistema de pesos que são definidos, em nível setorial, para os temas em relação a cada uma das dimensões da sustentabilidade: social, econômica e ambiental; e em nível global. Dessa forma, a cada indicador é associado um peso que permite avaliar a contribuição do indicador, de forma setorial e global, para o resultado do IMUS.

O peso para os indicadores que compõem o IMUS foi obtido por meio de consulta realizada via internet aos especialistas nas áreas de planejamento urbano, transportes, mobilidade e sustentabilidade do Brasil e de outros países, como Portugal, Alemanha, Austrália e Estados Unidos. 
Tabela 2: Indicadores revisados por Costa (2008).

\begin{tabular}{|c|c|c|c|}
\hline Iniciativas & $\begin{array}{l}\text { Número de } \\
\text { indicadores }\end{array}$ & Iniciativas & $\begin{array}{l}\text { Número de } \\
\text { indicadores }\end{array}$ \\
\hline Agenda 21 & 132 & PROSPECTS (2002) & 44 \\
\hline Baltic 21 & 25 & Qualidade de Vida/ Porto & 72 \\
\hline Banister & 15 & Scottish Enterprise Tayside & 22 \\
\hline Bossel & 247 & Seattle & 40 \\
\hline Campos e Ramos & 26 & SIDS & 132 \\
\hline Cardiff & 59 & SNIU & 72 \\
\hline Indicators of Sustainable Development & 30 & SPARTACUS & 29 \\
\hline $\mathrm{ECl}$ & 10 & STPI & 14 \\
\hline Environment Canada & 08 & SUMMA & 60 \\
\hline Euskadi/ Governo Basco & 87 & Sustainable Measures & 319 \\
\hline Fife Council & 42 & SUTRA & 39 \\
\hline Hertfordshire (2005) & 25 & TERM (2001-2003) & 61 \\
\hline Hertfordshire (2003) & 82 & TRANSPLUS & 49 \\
\hline Hertfordshire (1999) & 45 & Sustainable Indicators & 11 \\
\hline IBGE & 59 & UN/CSD & 63 \\
\hline IQVU/BH & 39 & UNCHS & 42 \\
\hline Library of Local Performance Indicators & 272 & USDOT & 120 \\
\hline LITMUS & 36 & STPI & 34 \\
\hline Mendes/QV & 54 & Victoria Institute & 40 \\
\hline Mendip Council & 44 & Victoria Transport Policy & 19 \\
\hline New Zeland & 33 & WBCSD & 31 \\
\hline NRTEE & 08 & ANTP & 25 \\
\hline OECD & 32 & Obs. Cidadão Nossa São Paulo & 118 \\
\hline Ontario transportation & 21 & NTU & 16 \\
\hline PROPOLIS & 60 & São Paulo em Movimento & 154 \\
\hline PROSPECTS (2001) & 26 & & \\
\hline
\end{tabular}

Fonte: Costa (2008), Machado (2010).

O IMUS possui como característica a utilização de vários temas que estão afetos a mobilidade urbana sustentável nas áreas urbanas. A feição constitui seu mérito e também sua fragilidade, pois a aplicação demanda muito tempo para pesquisa e coleta de dados, o que pode inviabilizar o cálculo, além de nem todas as informações estarem disponíveis.

Ao mesmo tempo em que é uma excelente ferramenta de diagnóstico, permitindo sua aplicação para predizer se uma cidade é dotada de um bom índice de mobilidade, possui pouca aplicabilidade prática para a fase de planejamento, ou seja, na concepção de desenho e de elaboração de planos diretores. De qualquer forma, essa foi à proposta mais ampla, consistente e correlata à presente pesquisa, além de ter sido produzida para a realidade das cidades brasileiras. Nesse sentido, o $\operatorname{IMUS}^{19}$ (2008) foi analisado para identificar os indicadores que serão ajustados ao procedimento de análise utilizado no estudo de caso.

Importa ainda acrescentar que a investigação desta tese, ao contrário do que é proposto por Costa (2008), testa um número reduzido de variáveis, já que o foco é tratar de forma e mobilidade - e conduzir uma aplicação expedita. O reduzido número de variáveis também se

\footnotetext{
${ }^{19}$ O Guia de Indicadores do IMUS encontra-se na tese de Costa (2008), Anexo E.
} 
vincula ao objetivo de tornar a pesquisa mais praticável, ou seja, tornar o processo de avaliação de mobilidade sustentável mais operacional e voltado para o planejamento urbano.

2.6.2 Ajuste das variáveis e eixos de análise para utilização na pesquisa.

A partir dos conceitos analisados sobre forma urbana é possível assumir que as variáveis (cf. Quadro 9): características da densidade, características do uso do solo urbano, continuidade (redução de vazios) e características do desenho urbano podem, teoricamente, influenciar a mobilidade urbana com maior ênfase. A influência ocorre tanto para parâmetros não desejados, quanto para parâmetros que possam potencializar a mobilidade urbana sustentável, o que vai depender da disposição de cada uma dessas variáveis em determinada área urbana e de sua articulação com os elementos de transporte e circulação.

Teoricamente, essas quatro variáveis, ajustadas ao modelo de cidade compacta, levam à redução das distâncias de viagem e contribuem para a implantação de um sistema de transporte integrado, o que fomenta a utilização dos transportes não-motorizados e, sobretudo, auxilia na redução do uso do transporte individual, conduzindo à mobilidade sustentável. A partir destas conclusões, adotou-se uma simplificação, conforme ilustra o esquema apresentado na Figura 13.

Por meio da simplificação do problema, ficaram estabelecidos dois eixos de análise que contêm as variáveis a serem testadas no estudo de caso. O Eixo de Análise I contém as variáveis da forma urbana (Elementos da Forma Urbana). O Eixo de Análise II foi construído com ênfase na utilização dos transportes não-motorizados e do transporte público como indutor para mobilidade sustentável, a partir de alguns indicadores sugeridos no IMUS.

O Eixo de Análise II atende também à Lei de Mobilidade para Política Nacional de Mobilidade Urbana, que prioriza, em seu texto, a utilização dos modos de transporte nãomotorizados e dos serviços de transporte público coletivo sobre o transporte individual motorizado. As variáveis do Eixo de Análise II estão relacionadas à qualidade da infraestrutura ofertada para transporte público e não-motorizados sem os quais não há deslocamento (Elementos de Transporte e Circulação).

O Quadro 11 descreve os eixos de análise e as variáveis que serão testadas no estudo de caso. Para cada variável, foi considerado um correspondente indicador na tabela de indicadores de mobilidade urbana sustentável proposta por Costa (2008) (cf. Capítulo 3). 


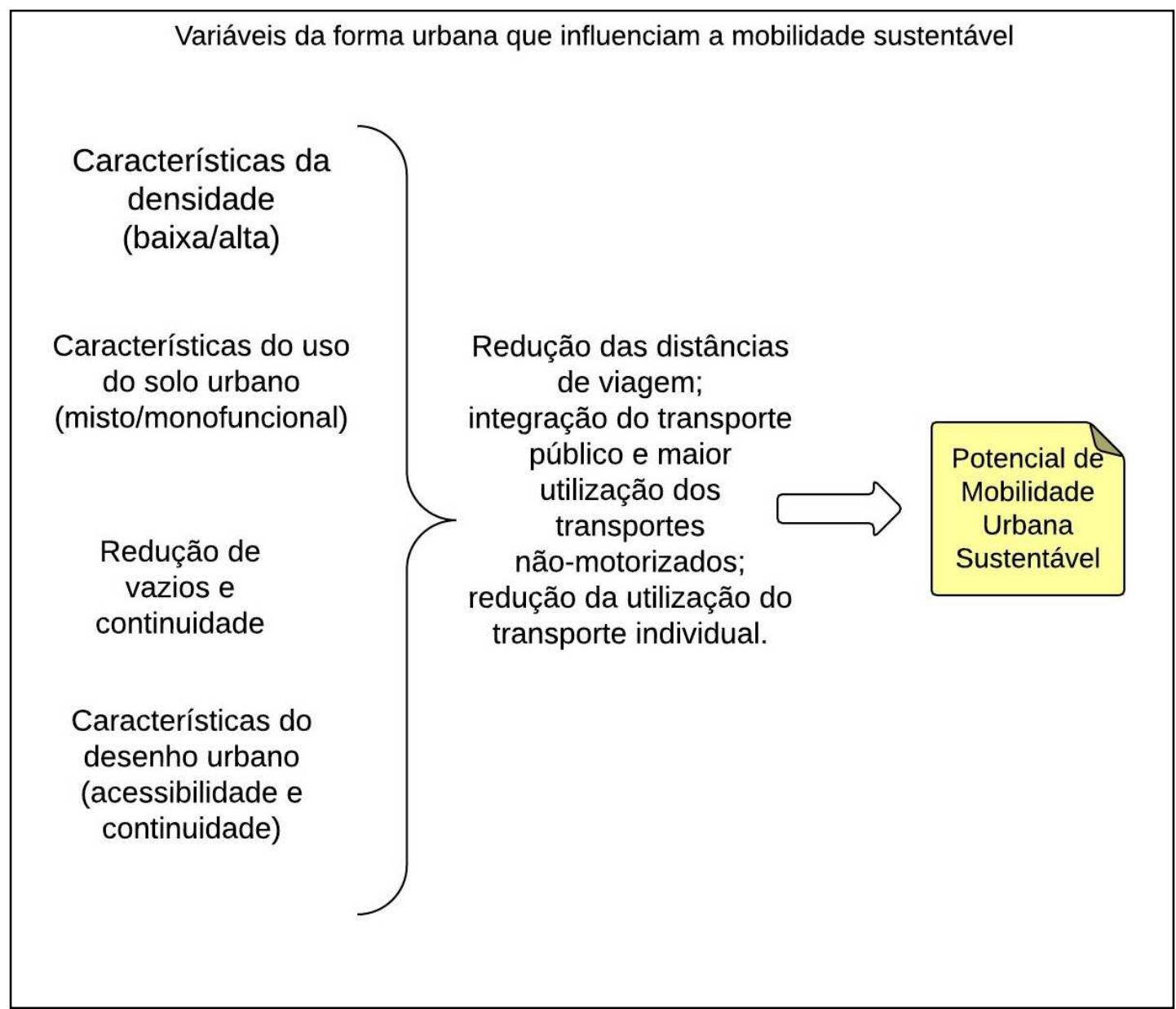

Figura 13: Análise das variáveis da forma urbana e sua relação com a mobilidade sustentável: simplificação do problema.

Quadro 11: Variáveis e eixos de análise.

\begin{tabular}{|c|c|}
\hline Eixo de Análise I: forma urbana & Eixo de Análise II: transporte e circulação \\
\hline $\begin{array}{l}\text { Característica da densidade } \\
\text { Característica do uso do solo urbano } \\
\text { Continuidade (redução de vazios) } \\
\text { Características do desenho urbano } \\
\text { (conectividade e acessibilidade do } \\
\text { sistema viário) }\end{array}$ & $\begin{array}{l}\text { Extensão da rede de transporte público } \\
\text { Acessibilidade ao transporte público (cobertura do } \\
\text { transporte público) } \\
\text { Vias para pedestres } \\
\text { Extensão e conectividade de ciclovias. }\end{array}$ \\
\hline
\end{tabular}

Entre as variáveis dispostas no Eixo de Análise I, é importante considerar o que foi colocado na revisão de literatura sobre “configuração formal-espacial”. No Eixo de Análise I, é possível fazer uma segunda classificação, dividindo-o em duas famílias de variáveis já que existem dois polos de análises diferentes: o formal e o espacial (Figura 14). Porém, este fato não interfere no estudo que se propõe nesta tese. 


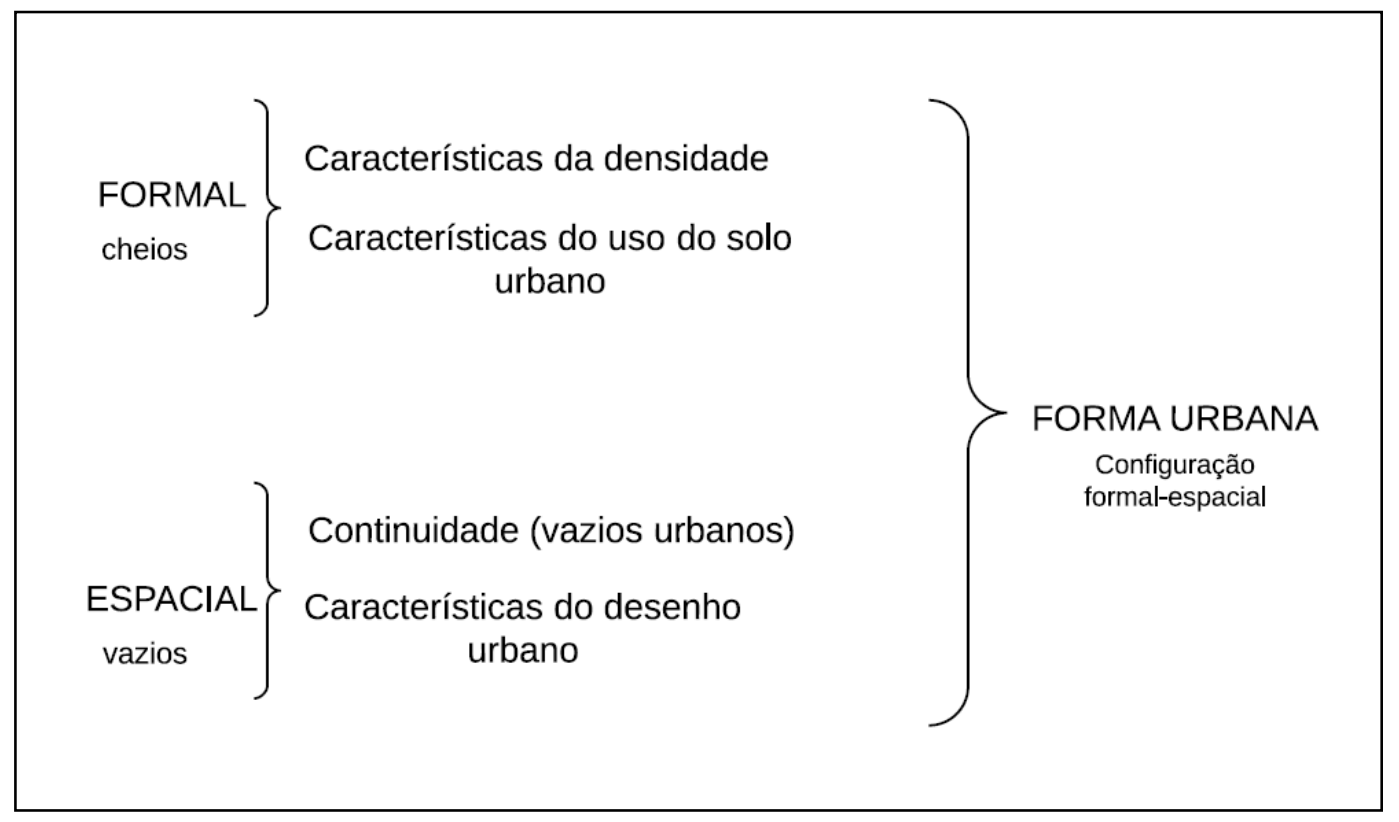

Figura 14: Famílias de variáveis no eixo de análise I.

\subsection{Considerações finais do capítulo}

Este capítulo procurou abordar as questões conceituais relacionadas à mobilidade e forma urbana. Apesar de uma vasta gama de definições e conceitos que envolvem tais temas, no que tange à mobilidade urbana verificou-se que a significação é recente e pouco consolidada. Assim este trabalho coaduna-se com as definições desenvolvidas, principalmente, pelo Ministério das Cidades (2005), que, por sua vez, deriva daquelas estabelecidas para o desenvolvimento sustentável. Cabe ressaltar a importância da Lei de Mobilidade, que trouxe pontos úteis para potencializar a mobilidade sustentável nos aspectos de gestão do sistema de transporte. Entretanto, a legislação, pouca ênfase deu aos elementos da forma urbana.

Com relação à forma urbana, foram descritos os conceitos sobre o tema, introduzindo também as características da cidade compacta e dispersa. Conclui-se que as feições da cidade compacta parecem trazer maiores possibilidades para um espaço com atividades sobrepostas, multifuncional e com melhores opções de desenho urbano para o transporte público e nãomotorizados, ao contrário da cidade dispersa. Foram extraídos dos polos conceituais as variáveis que influenciam a mobilidade urbana e que serão testadas na próxima etapa deste trabalho.

O estudo dos indicadores de mobilidade sustentável apontou para a robusta contribuição do trabalho de Costa (2008), consubstanciado no guia de indicadores elaborado pela autora. A pesquisa serviu de apoio principal para o detalhamento das variáveis de forma 
urbana. Além disso, contribui para identificação das relações morfológicas com o sistema de transporte e circulação para a proposta dos eixos de análise I e II, que serão utilizados no estudo de caso. 


\section{CAPÍTULO 3: ELABORAÇÃO DE PROCEDIMENTO DE ANÁLISE ESPACIAL}

\section{INTRODUÇÃO}

No capítulo anterior, por meio da revisão de literatura, foi possível selecionar e relacionar variáveis afetas à forma urbana e à mobilidade. Para esta sessão, propõe-se a construção de um procedimento analítico que permita a verificação, por meio da adoção dos dois eixos de análise: Eixo de Análise I - Forma Urbana e; Eixo de Análise II - Transporte e Circulação. São descritas as etapas de construção de um Procedimento de Análise Espacial de modo a testar as variáveis em estudo de caso, e assim, permitir o alcance das respostas às questões do estudo.

\subsection{Desenvolvimento do Procedimento de Análise Espacial}

O desenvolvimento de um procedimento analítico mostrou-se como uma das mais desafiadoras etapas da pesquisa, uma vez que o que se buscava era relacionar forma urbana e mobilidade, por meio da verificação das características do espaço urbano que correlacionassem os seus elementos estruturantes com o correspondente desempenho da mobilidade sustentável para o planejamento urbano.

Em função disso, procurou-se elaborar um "Procedimento de Análise Espacial” que pudesse estabelecer graus de indução dos elementos da forma urbana em relação à mobilidade, tendo em conta que os mesmos não ocorrem de forma isolada. Igualmente, adotou-se uma estratégia que pudesse: (i) espacializar as variáveis que são potencialmente responsáveis pela mobilidade urbana sustentável e; (ii) hierarquizar as relações entre os elementos da "Forma Urbana" e de "Transporte e Circulação".

Para dar conta da variabilidade dos diferentes arranjos espaciais, foram identificadas abordagens que trabalhassem com incertezas. Os estudos (Ribas, 1988; Ribas, 2003; Faria, 1996; Ian MacHarg, 1969) remeteram-nos aos métodos de avaliação de riscos ambientais que lidam com um conjunto amplo de possibilidades de arranjo entre variáveis e também com graus de incerteza sobre os efeitos esperados e que conseguem, com certo nível de assertividade, estabelecer graus de risco de ocorrência de impactos negativos e positivos.

A partir destas considerações, a escolha recaiu sobre a Análise de Risco Ecológico (ARE) que deriva de estudos ambientais de sustentabilidade (Faria, 1996) e assume que, para se avaliar determinada área, deve-se seguir o princípio da seleção de critérios. De modo geral, o método propõe uma espécie de estrutura em árvore que conduz a escolhas e interpretações 
para cada unidade de análise espacial, até se chegar a um resultado em uma determinada matriz. O método possibilita quantificar, hierarquizar e espacializar os riscos que determinadas atividades antrópicas podem representar para os fatores naturais da paisagem.

De modo análogo, buscou-se na interpretação deste método (ARE), as bases para se estabelecer um novo Procedimento de Análise Espacial, no qual fosse possível, quantificar, hierarquizar e espacializar os efeitos provenientes de determinado arranjo da forma urbana nas condições de mobilidade, considerando os Eixos de Análise I e II citados. O próximo item trata da descrição da ARE para estabelecer as lógicas que foram adequadas para montagem do Procedimento de Análise Espacial utilizado nesta pesquisa.

\subsection{Aspectos conceituais, metodológicos e técnicos da Análise do Risco Ecológico.}

\subsubsection{Aspectos conceituais}

A Análise do Risco Ecológico ou ARE é um método analítico desenvolvido no âmbito do planejamento territorial e aplicado na avaliação de impactos ambientais; deriva de estudos de Ian McHarg (1971). Tem como referencial teórico, a Teoria do Planejamento Ecológico ${ }^{20}$, desenvolvida em 1972 por pesquisadores alemães da Akademia fur Raumforschung und Landesplanung de Hannover (FARIA, 1996; PASSOS, 2007).

O objetivo principal é localizar e identificar a extensão dos efeitos das atividades antrópicas sobre o meio ambiente, permitindo desta forma, quantificar, hierarquizar e espacializar os riscos ambientais conforme um conjunto de informações que se tem da área analisada.

O método procura integrar os recursos naturais ao planejamento, por meio de dois tipos de avaliação: do potencial natural para vários tipos de usos e do impacto desses usos sobre o meio ambiente natural, isto refere-se à SENSIBILIDADE dos recursos naturais a danos, e INTENSIDADE de danos potenciais causados pela atividade humana (RIBAS, 1988).

A combinação entre sensibilidade dos recursos naturais a danos (sensibilidade) e intensidade de danos potenciais (intensidade) referente a cada área analisada constitui-se na dimensão do Risco Ecológico ou Risco de Danos aos fatores naturais. O conceito de risco está relacionado com a provável (e não certa) hipótese de acontecimento do evento.

\footnotetext{
${ }^{20}$ Teoria do Planejamento Ecológico apresenta-se como base conceitual para viabilizar as recomendações de um planejamento espacial que propõe que o planejamento regional e local passe a inserir componentes ecológicas nos seus objetivos (FARIA, 1996).
} 
A análise do risco oferece um ferramental metodológico onde se estabelece um complexo de relação causa/efeito (Figura 15), e tem-se: usos, como causa dos impactos; e as modificações qualitativas e quantitativas como efeito. Isto permite dizer que a ARE é feita a partir da análise das relações de troca entre dois sistemas: o das atividades humanas, como causador dos efeitos negativos (intensidade de danos potenciais) e o dos fatores naturais (sensibilidade dos recursos naturais a danos), como receptor desses efeitos (Ribas, 1988).

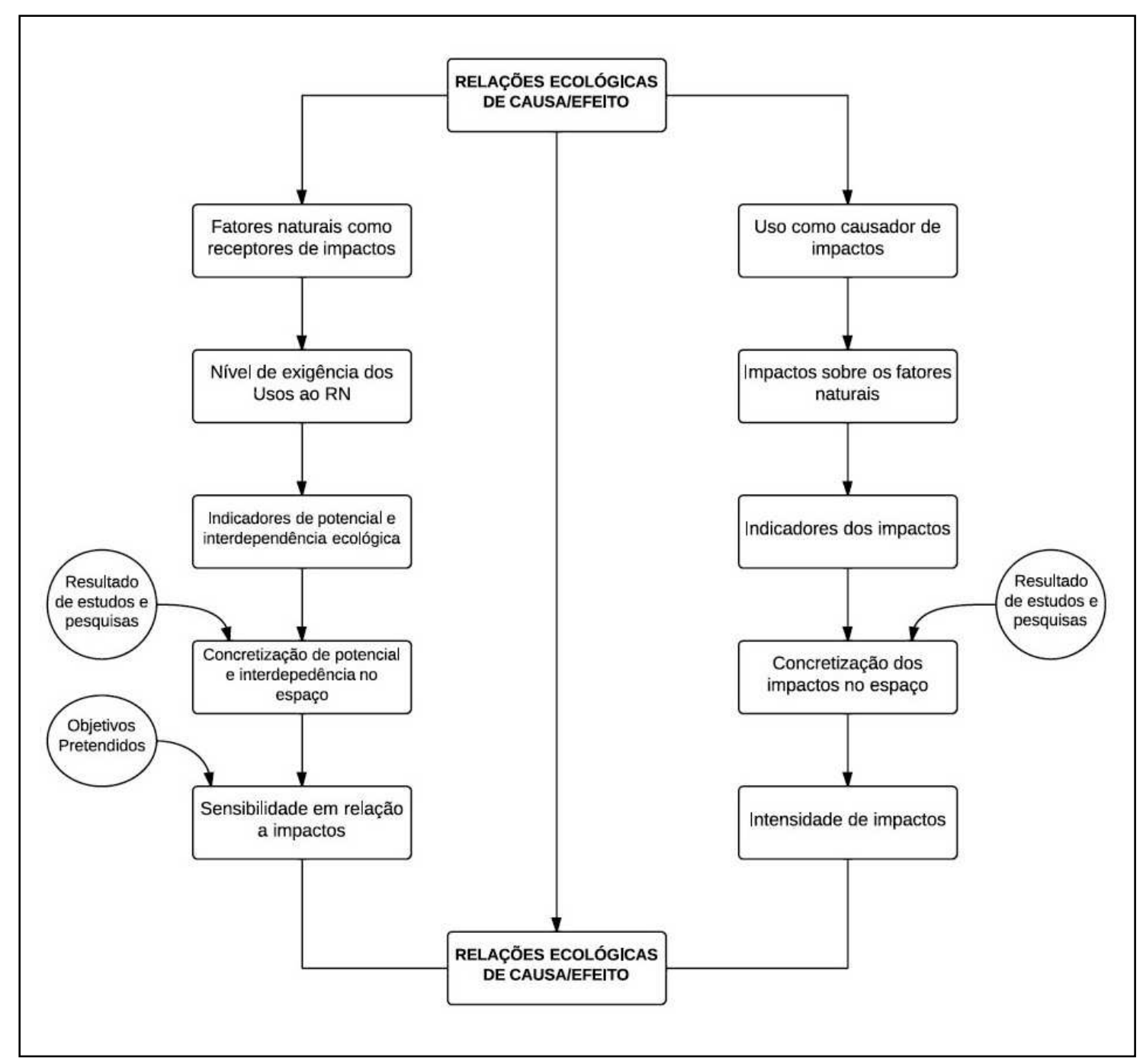

Figura 15: Esquema básico: Análise de Risco. Fonte: Bachfischer, (1978, p.80; apud Ribas, 1988, p.28)

A operacionalização das relações entre sensibilidade e intensidade é obtida por meio de análises combinatórias (cf. item 3.2.2), em que a função de agregação das variáveis que compõe intensidade e sensibilidade é realizada por meio da lógica matemática (álgebra booleana) representada por diagramas do tipo "árvore" para inferir o risco ecológico. A disponibilidade de dados é um critério determinante, já que a determinação do risco é obtida a partir de dados sistematizados no momento (base de dados existente), o que confere ao 
método, "[...] agilidade temporal e praticidade, atributos essenciais para uma tomada de decisão estratégica (RIBAS, 2003)".

As limitações referentes à ARE referem-se ao fato de haver uma impossibilidade de serem introduzidos no procedimento os fatores ambientais que não podem ser mapeados. Além disso, há difícil integração dos impactos socioeconômicos, com a subjetividade na escolha dos parâmetros que definem as potencialidades e sensibilidades do projeto em questão. Outra fragilidade do método incide no fato de ser preditivo, o que o limita a estabelecer um grau de risco a partir das variáveis selecionadas, sem a preocupação de correlacionar as possíveis respostas para redução ou eliminação do risco (MOREIRA, 1992; RIBAS, 2003).

A principal vantagem da ARE, por outro lado, está na capacidade de representar a distribuição espacial dos impactos, expressando de modo mais direto e compreensível o resultado da interação de sensibilidade e intensidade na área em estudo. Além disso, é de concretização relativamente fácil, adaptando-se à base de dados disponível sobre cada área urbana.

A estrutura conceitual e metodológica da ARE será utilizada para estabelecer uma estratégia de leitura entre a interação "Forma Urbana" e "Transporte e Circulação", pois entende-se que neste caso também há uma relação de causa/efeito ${ }^{21}$; em que, Forma Urbana pode intensificar e/ou auxiliar na criação de espaços favoráveis a adequação dos elementos de Transporte e Circulação.

\subsubsection{Aspectos metodológicos}

Os elementos utilizados para representação dos resultados da ARE são: "árvores de avaliação", "matriz de agregação" e, finalmente, o "mapa de risco", que contém a indicação dos níveis de risco, conforme ilustra o esquema da Figura 16, observando-se os seguintes passos metodológicos:

i. Identificação dos indicadores que definem a intensidade de danos potenciais (intensidade): agregação é conduzida por meio da árvore de avaliação intensidade;

\footnotetext{
${ }^{21}$ Reforçando a ideia de interdependência (conjunto de ações interdependente) entre Forma e Mobilidade, já mencionada nos capítulos iniciais.
} 
ii. Identificação dos indicadores que definem a sensibilidade dos recursos naturais a dano (sensibilidade): agregação é conduzida por meio da árvore de avaliação sensibilidade;

iii. Combinação da intensidade de danos potenciais com a sensibilidade a danos por meio de uma matriz de risco;

iv. Definição e recomendações por nível de risco estabelecido, de acordo com os resultados apresentados em um mapa de risco - espacialização dos resultados.

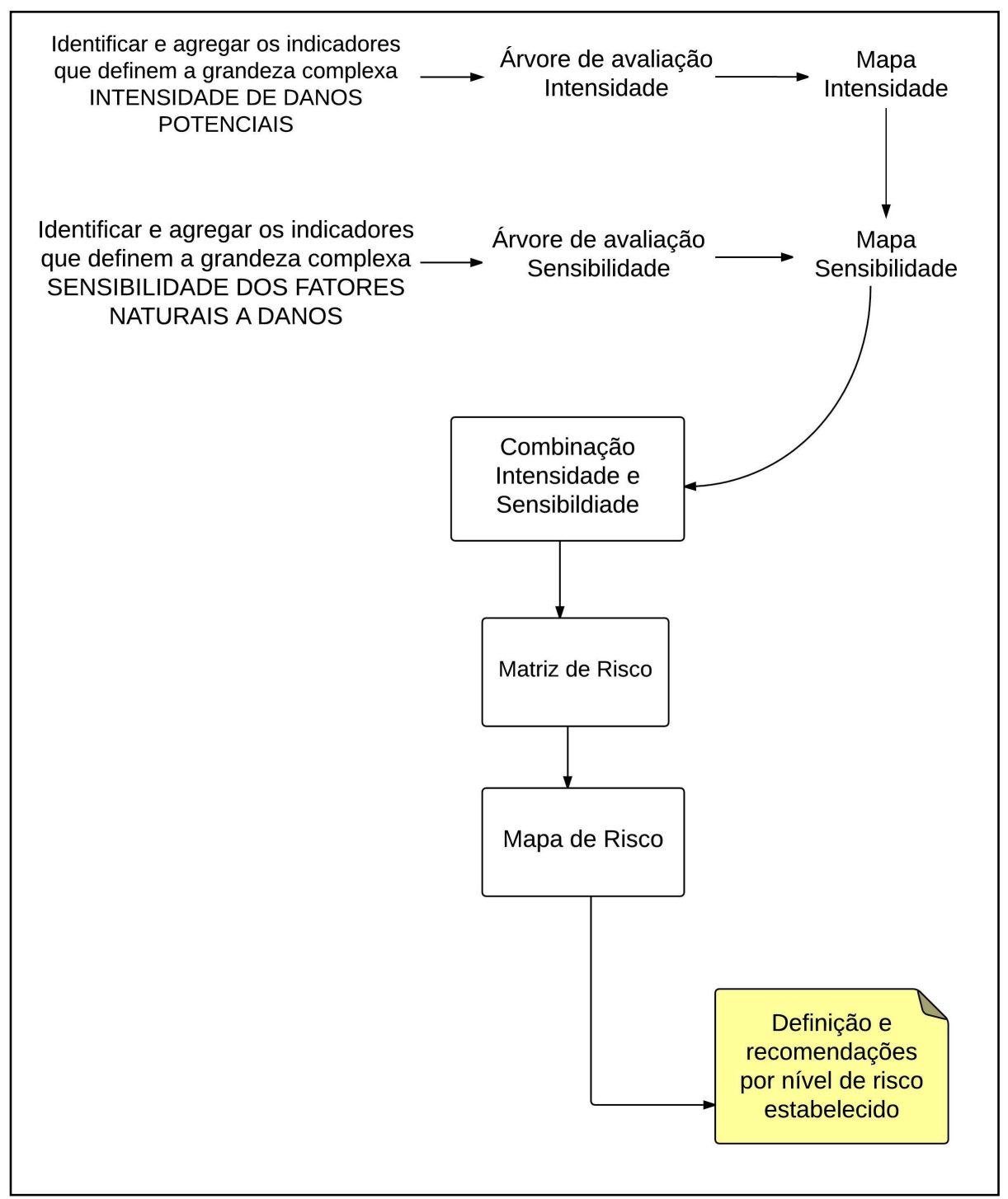

Figura 16: Esquema mostrando as etapas do método ARE.

Para operacionalizar o método em questão, é imprescindível o uso de indicadores para caracterizar INTENSIDADE e SENSIBILIDADE. Em razão disso, antes da agregação dos indicadores, são fixados valores limites para cada indicador. 
A agregação dos indicadores é elaborada utilizando combinações lógicas do tipo "e/ou" (álgebra booleana), que são representadas na forma de diagrama tipo "árvores de decisão e avaliação" (Figura 17), resultando na "intensidade de danos potenciais" causados por usos e "sensibilidade dos fatores naturais a danos". A agregação permite combinar elementos de natureza diversa nesse sistema denominado "árvore de decisão ou avaliação".

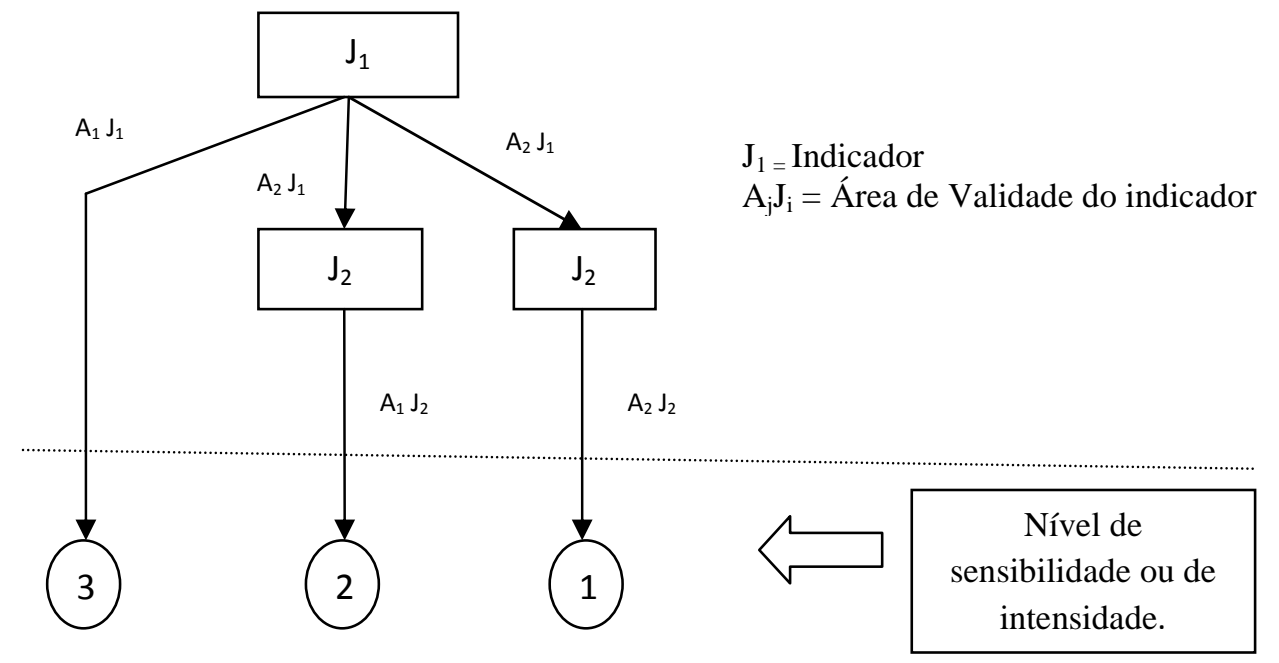

Figura 17: Árvore de avaliação de grandezas da análise de risco. Fonte: Ribas, (2003).

A álgebra booleana ${ }^{22}$ é uma área da matemática que trata de regras e elementos de lógica. Tais princípios baseiam-se em um sistema de álgebra (álgebra das proposições) onde pode-se determinar se uma sentença é falsa ou verdadeira utilizando-se para isso as funções lógicas ou operadores lógicos: E, OU e NÃO.

A Álgebra de Boole define um conjunto de postulados e operações lógicas com variáveis binárias que só podem assumir um número finito de valores, em particular de dois valores, que geralmente são denotados por [F, V] falso ou verdadeiro ou ainda $[0,1]$.

Como o número de valores que cada variável pode assumir é finito (e pequeno), o número de estado que uma função booleana pode assumir também será finito. Significa que é possível descrever as funções booleanas utilizando tabelas (tabela verdade) ou diagramas (árvores), que por definição, são estruturas que reúnem um conjunto de possibilidades combinatórias entre valores de diversas variáveis - são listadas todas as combinações de valores que as variáveis podem assumir e os correspondentes valores de saída.

Os operadores lógicos "E/OU” são utilizados para fazer as combinações lógicas de valores das variáveis:

\footnotetext{
${ }^{22}$ Álgebra de Boole foi desenvolvida pelo matemático e filósofo Inglês George Boole (1815-1864).
} 
- Operador OU: denominado adição lógica. O símbolo OU pode ser representado por meio do símbolo da adição algébrica dos números reais “+”; entretanto, no caso da álgebra booleana, não se trata de adição algébrica, mas sim de adição lógica de variáveis;

- Operador E: a operação E significa multiplicação lógica, outra notação para E é “.”.

As funções de agregação dos indicadores no método ARE são feitas utilizando operações lógicas do tipo E/OU representadas na forma de diagrama tipo "árvore”. Um dos aspectos mais positivos da Análise de Risco Ecológico é o método de agregação de indicadores pelas operações do tipo E/OU da álgebra booleana. Além de oferecer a possibilidade de se considerar, explicitamente, todas as combinações de indicadores, esse método permite que sejam incorporados à análise, indicadores dos mais diferentes níveis de exatidão e comprovação empírica (FARIA, 1996).

A obtenção do Risco Ecológico é orientada por uma matriz binária (Figura 18), que deve ser construída com base nos níveis de "Intensidade de danos potenciais" e "Sensibilidade dos fatores naturais a danos" que resultarem das análises realizadas. Portanto, a composição dessa matriz pode variar de acordo com cada situação.

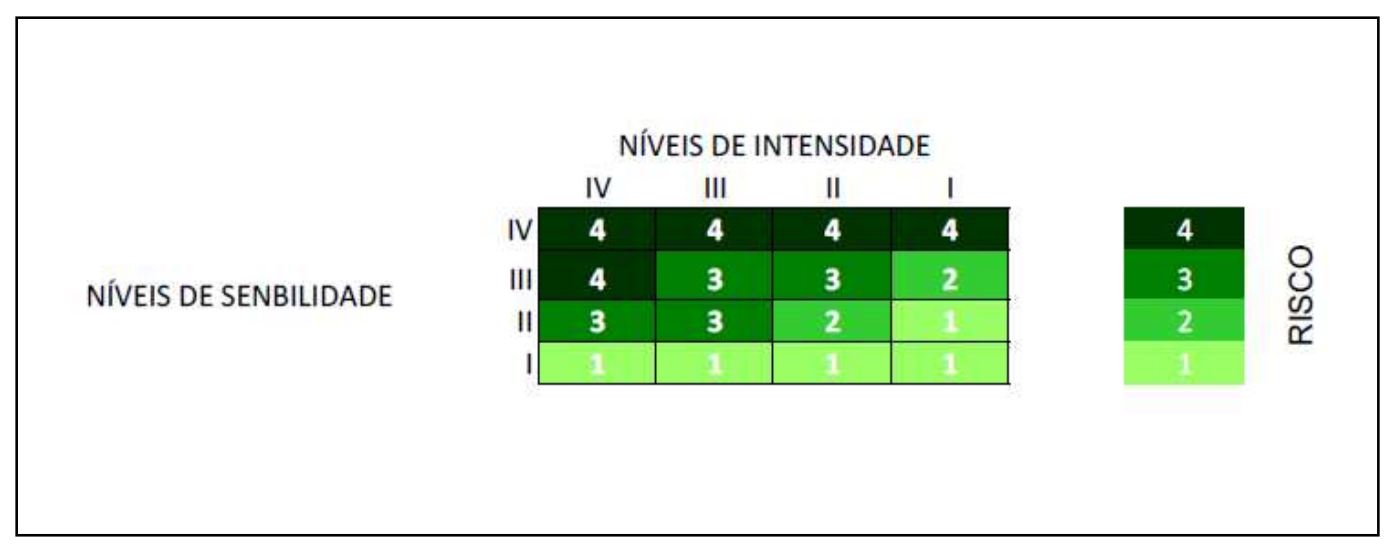

Figura 18: Exemplo de matriz de combinação de indicadores de risco ecológico. Fonte: Faria, (2006) Adaptado.

\subsubsection{Aspectos técnicos}

Os aspectos técnicos da ARE são as ferramentas e os recursos utilizados para o desenvolvimento do método. Para análise do risco, utiliza-se da seguinte técnica:

i. Geoprocessamento: todos os indicadores devem ser espacializados; para isso, utilizase de software de geoprocessamento que congrega, em um mesmo banco de dados, informações vetoriais (informações cartográficas) e dados diversos, otimizando o 
tratamento das informações. Nesta plataforma, é possível fazer a sobreposição de todas as camadas de informações.

\subsection{Avaliação do potencial de mobilidade sustentável: Procedimento de Análise Espacial}

Para avaliar o potencial de mobilidade sustentável, relacionando forma e mobilidade, e testar as variáveis dispostas nos Eixos de Análise I e II, buscou-se no arranjo conceitual e metodológico da ARE os instrumentos para estabelecer um novo procedimento de investigação. Inicialmente, é importante estabelecer a relação entre os dois eixos de análise, conforme explicitado abaixo e ilustrado na Figura 19:

i. Eixo de análise I - Elementos da Forma Urbana: grupo das variáveis que dão sustentação ou que intensificam o processo de mobilidade sustentável;

ii. Eixo de análise II - Elementos de Transporte e Circulação: grupo de variáveis que pode ser potencializado, a depender da maneira como forem articuladas aos elementos da forma urbana, colaborando para um status de mobilidade sustentável.

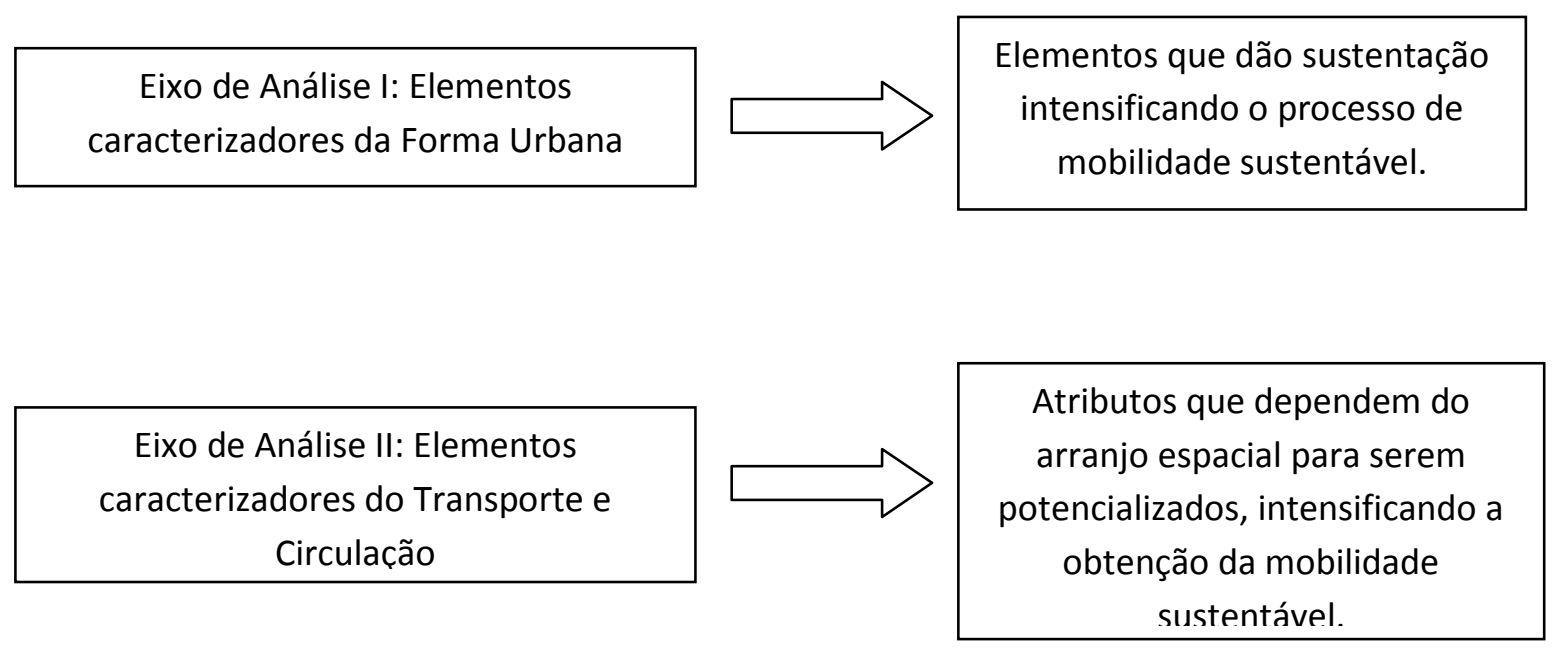

Figura 19: Articulação entre os eixos de análise.

Nesta pesquisa, a combinação dos dois eixos de análise demonstrará áreas urbanas com maior e menor potencial para mobilidade sustentável. Em função disso, é feita a agregação dos indicadores dispostos nos eixos de análise. A agregação é necessária já que, ao serem analisadas as condições da mobilidade urbana, torna-se importante a avaliação conjunta de elementos que possam potencializar a mobilidade sustentável e não a análise isolada de cada variável, em qualquer dos eixos. O conceito de potencial assemelha-se ao de risco 
(conforme colocado na $\mathrm{ARE}$ ) e está relacionado com a provável (e não certa) indicação de espaços mais favoráveis à mobilidade sustentável.

Os passos metodológicos do Procedimento de Análise Espacial são (Figura 20):

i. Decomposição do sistema "Forma" e "Transporte" em subsistemas independentes, embora inter-relacionados;

ii. Agregação das variáveis do Eixo de Análise I para definir a "Árvore de Avaliação Forma Urbana";

iii. Agregação das variáveis do Eixo de Análise II para definir a "Árvore de Avaliação dos elementos de transporte e circulação";

iv. Por meio da composição de uma matriz, são verificadas as combinações para todos os níveis de análise existentes nas árvores "Forma" e "Transporte", gerando a grandeza agregada "Potencial de Mobilidade Sustentável";

v. Proposição de medidas de controle para cada nível de análise observado na matriz de agregação.

A agregação das variáveis é formulada por meio de um diagrama, tipo "árvore", em que são definidos os níveis qualitativos e quantitativos para os Eixos de Análise I e II, respectivamente "Forma Urbana" e "Transporte e Circulação". Posteriormente, o resultado é espacializado, utilizando-se a técnica de superposição de informações. Na leitura do diagrama, verifica-se a hierarquia que é estabelecida, considerando a variável mais importante que vem em primeiro lugar na árvore de avaliação.

A articulação das árvores de avaliação levará a um mapa da área urbana analisada, que será chamado de "Mapa Potencial da Mobilidade Sustentável". O mapa potencial da mobilidade vai indicar os espaços mais favoráveis à mobilidade sustentável de determinada área urbana considerando as variáveis analisadas (Figura 21). 


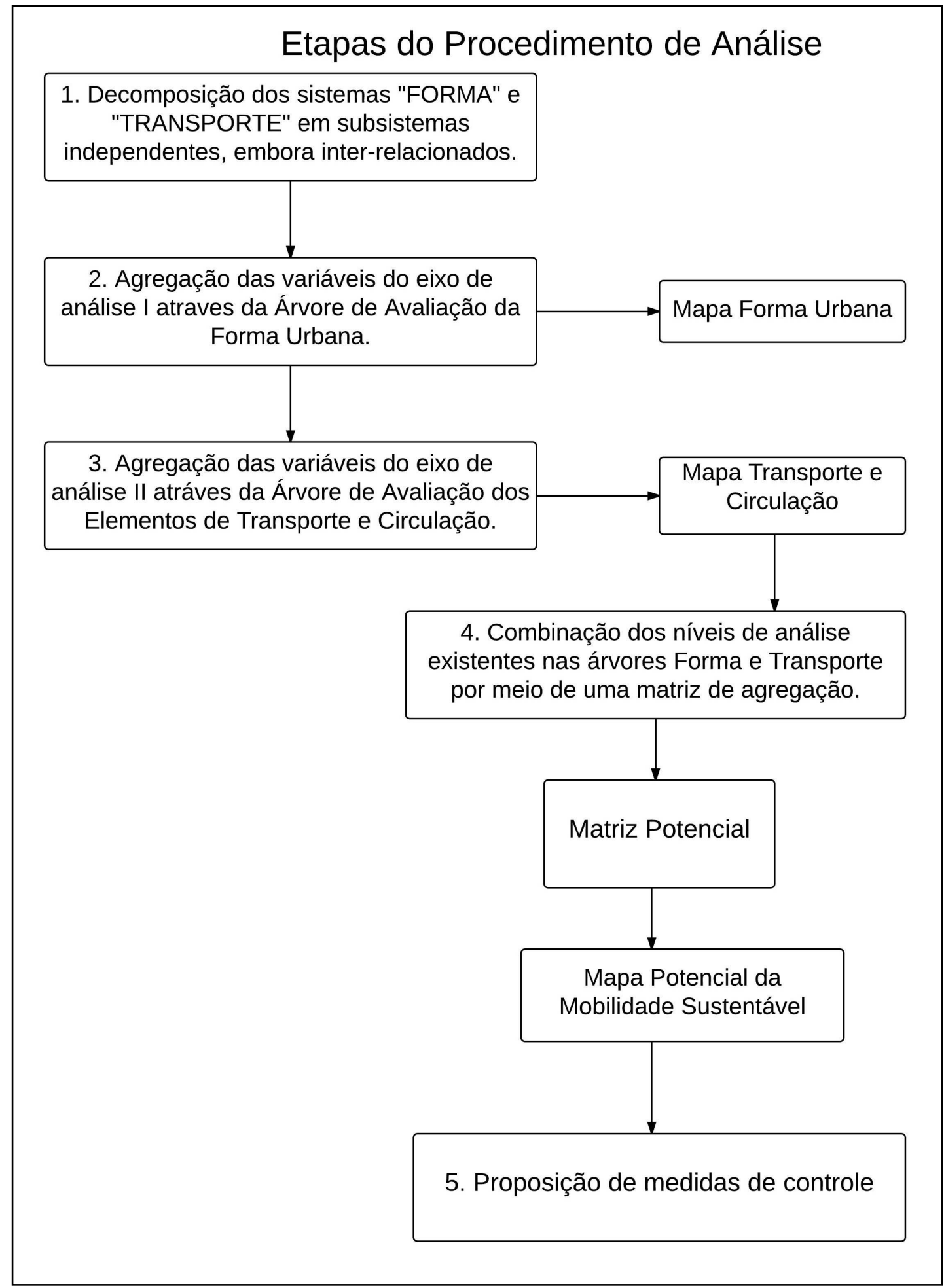

Figura 20: Esquema ilustrativo das etapas do Procedimento de Análise Espacial. 


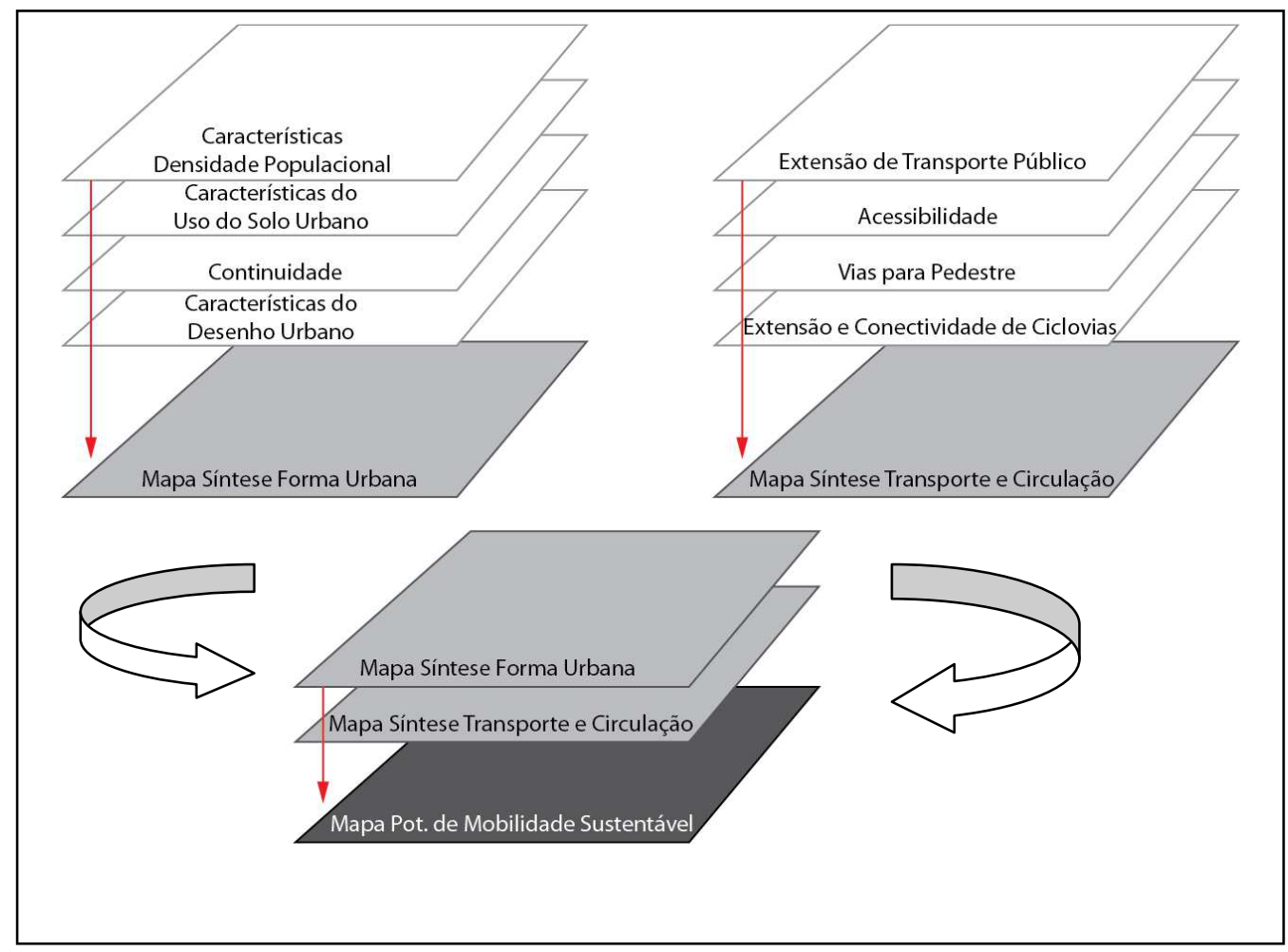

Figura 21: Esquema mostrando a sobreposição das variáveis do estudo.

Conforme mencionado no item anterior, para agregação das variáveis, utiliza-se álgebra booleana por meio das combinações lógicas do tipo "E/OU”, de modo que em cada árvore de avaliação são definidas as combinações lógicas (usando os operadores E/OU). Posteriormente é utilizanda a técnica de superposição de informações com o auxílio dos softwares Excel e ArcGis. Por fim, para aplicação do Procedimento de Análise Espacial, devem ser observados os seguintes critérios que viabilizarão as adequações necessárias para o desenvolvimento metodológico:

i. As variáveis definidas em cada eixo de análise (Eixo I: densidade populacional, uso do solo urbano, vazios urbanos e desenho urbano; Eixo II: extensão de rede de transporte público, cobertura do transporte público, extensão e conectividade de ciclovias, vias para pedestres) devem possuir indicadores baseados no conhecimento científico disponível para que se possa criar uma escala de avaliação: para fixar os valores limites de cada variável e criar uma escala de avaliação, será utilizado o Guia de Indicadores para obtenção do Índice de Mobilidade Urbana Sustentável - IMUS, proposto por Costa (2008). As variáveis correspondentes aos Eixos de Análise I e II possuem um correspondente indicador nesta lista. Apenas a variável Característica do Desenho Urbano será calculada utilizando a variável configuracional denominada de Integração 
Global e derivada do mapa axial obtido pela sintaxe espacial (SE) (cf. item 3.3.1.1); sendo assim, sua escala de avaliação também será diferenciada, conforme se verá adiante;

ii. É importante que as variáveis selecionadas possam ser espacializadas;

iii. Para a definição da área de análise ou escala de análise deve ser definida uma escala macro e outra micro. A escala macro pode ser o perímetro urbano ou, no caso de regiões metropolitanas, considerar as cidades que estão conurbadas, ou a mancha urbana. Para a escala micro, consideram-se subáreas que podem corresponder à escala de bairros ou regiões administrativas. A definição das escalas macro e micro para aplicação do Procedimento de Análise Espacial permitirá uma análise global em relação ao potencial de mobilidade sustentável e também uma análise local, sendo possível estabelecer comparação entre áreas distintas no mesmo território urbano;

iv. A ordem e o arranjo das variáveis nos diagramas do tipo "árvore" são elaborados de maneira subjetiva. Quem introduz as variáveis na árvore deve estabelecer uma hierarquia na qual se destaque o elemento que possa ter maior relevância e impactos nos demais ${ }^{23}$; nesta etapa, contam a experiência do planejador e também o objetivo que se pretende alcançar. A matriz de agregação também segue essa lógica.

\subsubsection{Etapas do Procedimento de Análise Espacial da mobilidade urbana}

\subsubsection{Decomposição do sistema "Forma Urbana"}

Para avaliação da forma urbana, ficaram estabelecidas no item 2.6.2 (Capítulo 2) as seguintes variáveis para o eixo de análise I:

i. características da densidade;

ii. características do uso do solo urbano;

iii. continuidade (vazios urbanos);

iv. características do desenho urbano.

A definição das escalas de avaliação para cada variável será descrita abaixo. Importa saber que para cada variável proposta neste estudo, tem-se um correspondente indicador na tabela de indicadores proposta por Costa $(2008)^{24}$, conforme já mencionado. Por meio dessa

\footnotetext{
${ }^{23} \mathrm{O}$ pesquisador tem a liberdade de desenvolver o arranjo hierárquico da árvore de avaliação conforme seu entendimento teórico sobre as variáveis e a experiência no assunto. Isso confere ao Procedimento de Análise Espacial proposto certa flexibilidade, apesar da subjetividade.

${ }^{24}$ A forma de cálculo das variáveis: densidade populacional, uso misto, vazios urbanos, extensão de rede de transporte público, acessibilidade ao transporte público, vias para pedestres e extensão e conectividade de ciclovias seguiu as orientações contidas no Guia de Indicadores elaborado por Costa (2008).
} 
escala de avaliação (cf. Costa, 2008), definiu-se uma nova escala dividindo o score desses indicadores em dois ou três níveis de avaliação para cada variável, estabelecendo faixas de análise que podem ser classificadas em: alto, médio e baixo. A escala é crescente à medida que se cria uma situação favorável para mobilidade sustentável. Esta regra vale para todos os indicadores descritos.

\section{i. Características da densidade urbana}

Relevância - A manutenção de alta densidade em áreas urbanas constitui-se em um importante fator para controlar o espalhamento urbano. De acordo com Costa (2008), densidades populacionais mais elevadas reduzem a necessidade de transporte para acesso aos serviços e atividades, o que diminui também os custos de transporte, aumentando sua eficiência. Em termos econômicos, um maior adensamento populacional em áreas já atendidas por serviços básicos, incluindo o transporte público, constitui-se em uma das soluções para minimizar a carência de infraestrutura, reduzindo os investimentos em infraestrutura, e beneficiando um maior número de pessoas. Em termos ambientais, a manutenção de densidades urbanas elevadas diz respeito à redução da necessidade de novas áreas para desenvolvimento e a consequente redução nos impactos ambientais (COSTA, 2008).

Porém, elevadas densidades urbanas, associadas a um desenho urbano inadequado, podem implicar problemas sociais e ambientais, incluindo (COSTA, 2008):

- Maior demanda por empregos, moradia e serviços;

- Sobrecarga da infraestrutura;

- Aumento do consumo de bens e geração de resíduos;

- Aumento na emissão de poluentes no ar e na água.

Deste modo, o planejamento urbano deve considerar a manutenção de densidades urbanas adequadas à rede de infraestrutura e serviços básicos disponíveis, contribuindo para a racionalização do uso da infraestrutura e redução dos custos de transportes, sem prejuízo da qualidade ambiental das cidades.

Definição - O conceito geral de densidade é a relação entre o número de habitantes de um universo, considerando a área onde eles vivem, de modo a informar o grau de concentração populacional. Dependendo do fim para o qual é utilizado, pode apresentar variações quanto ao 
seu cálculo ${ }^{25}$. Costa (2008) assume que o indicador deverá ser calculado por meio da razão entre o total da população de determinada área urbana por unidade de solo urbano e nomeia o indicador como densidade populacional urbana, causando certa confusão com densidade demográfica. Entretanto, tal definição proposta pela autora aproxima-se do conceito de densidade média urbana, proposta por Ferrari (1981). Em função disto, será adotada a nomenclatura densidade urbana em sobreposição à densidade populacional urbana.

Unidade de medida - Habitantes/hectare.

Dados para cálculo do indicador - Área urbana que entrará na análise; população urbana do ano para cada área urbana analisada.

Fonte de dados - Base georreferenciada, fotos aéreas do software Google Earth e dados populacionais dos cenários territoriais e demográficos IBGE.

Cálculo - Em base georreferenciada deve ser delimitada a área efetivamente urbanizada; daí, calcula-se a razão entre o número de habitantes e a área urbanizada.

Normalização e Avaliação segundo Costa (2008) - Escala de avaliação para o indicador densidade urbana (Tabela 3):

Tabela 3: Escala de Avaliação para o indicador densidade urbana.

\begin{tabular}{|l|l|}
\hline Score & $\begin{array}{l}\text { Valores de Referência } \\
\text { Densidade populacional urbana }\end{array}$ \\
\hline 1,00 & 45.000 habitantes $/ \mathrm{km}^{2}$ ou 450 habitantes $/ \mathrm{ha}$ \\
\hline 0,75 & 35.000 habitantes $/ \mathrm{km}^{2}$ ou 350 habitantes $/$ ha \\
\hline 0,50 & 25.000 habitantes $/ \mathrm{km}^{2}$ ou 250 habitantes $/$ ha \\
\hline 0,25 & 15.000 habitantes $/ \mathrm{km}^{2}$ ou 150 habitantes $/$ ha \\
\hline 0,00 & $\begin{array}{l}\text { Até } 5.000 \text { habitantes } / \mathrm{km}^{2} \text { ou } 50 \text { habitantes } / \text { ha ou superior a } \\
45.00 \text { habitantes } / \mathrm{km}^{2} \text { ou } 450 \text { habitantes } / \text { ha }\end{array}$ \\
\hline
\end{tabular}

Fonte: Costa, (2008).

Escala de Avaliação da variável - Para criar a avaliação da variável característica da densidade urbana, considerou-se a classificação em alta e baixa densidade, dividindo a escala em dois polos de avaliação. Cabe destacar que, em relação aos preceitos brasileiros, a média da densidade urbana varia de 50 hab/ha a 150 hab/ha (DANTAS, 2003). A densidade

\footnotetext{
${ }^{25}$ Para o planejamento urbano é possível verificar três formas (FERRARI, 1981): i. densidade média urbana relação entre uma população urbana total e área urbana que a contém, ou seja, a área limitada pelo perímetro urbano da cidade: às vezes usa-se a área urbanizada para se ter uma ideia mais precisa da ocupação do solo; ii. densidade residencial bruta - relação entre o número total de habitantes e o total da área onde a população mora, trabalha, circula e descansa. Por área bruta entende-se a área total ocupada pelos lotes residenciais, pelas vias, áreas de estacionamento, áreas verdes de uso diário, escola e as áreas comerciais; excluem-se do cálculo áreas indústrias, áreas verdes de uso não diário, lagos ou rios e usos institucionais; iii. densidade residencial líquida - relação entre população residencial e área líquida na qual reside. Entende-se por área líquida a área ocupada pelos lotes residenciais edificados.
} 
econômica sugerida por Ferrari (1981), por exemplo, situa-se entre 250 hab/ha a 450 hab/ha. Essas informações indicam que, ao se fazer a análise de determinada área urbana no Brasil, considerando a proposta de Costa (2008) para avaliação da variável, teremos sempre baixas densidades. Em função disso, considerou-se na construção da "Árvore de Avaliação da Forma Urbana" a seguinte escala de avaliação:

- Baixa densidade: menor que 5.000 habitantes/ $\mathrm{Km}^{2}$ ou 50 habitantes/ha - (1)

- Alta densidade: acima de 5.000 habitantes/ $\mathrm{Km}^{2}$ ou 50 habitantes/ha - (2)

\section{ii. Características do uso do solo urbano}

Relevância - Este indicador mede o quanto os diferentes usos do solo encontram-se combinados dentro da cidade. De acordo com Costa (2008), o uso misto contribui para redução do tempo e da extensão das viagens e, por consequência, implica a redução da necessidade por viagens motorizadas, à medida que os serviços e atividades urbanas encontram-se distribuídos pelas diferentes regiões e, portanto, mais próximos dos locais de residência da população. Uma maior diversidade no uso resulta em benefícios sociais, econômicos e ambientais. Os benefícios sociais são traduzidos em ganho de tempo; os ganhos econômicos são representados por maior dinamismo urbano e maior acessibilidade da população às atividades econômicas e, por fim, em termos ambientais contribui para a redução dos deslocamentos motorizados e consequente redução do ruído, poluição atmosférica e consumo de combustível. Porém, é importante que os usos sejam compatíveis entre si, para evitar prejuízos no campo ambiental e para segurança e conforto da população.

Definição - Porcentagem de área urbana destinada ao uso misto do solo, conforme legislação. Unidade de Medida - Porcentagem da área urbana.

Dados de Base - Base georreferenciada, fotos aéreas, plano diretor do município.

Fonte de Dados - Prefeitura Municipal (secretaria de planejamento, urbanismo, etc).

Cálculo - Com base nos mapas de uso do solo e legislação urbanística sobre uso e ocupação do solo, identificar as áreas onde é incentivado o uso misto do solo. As áreas dessa natureza se constituem em porções do território destinadas à implantação de usos residenciais e não residenciais. O indicador é obtido pela razão entre a área total onde é permitido e/ou incentivado o uso misto do solo e a área urbana do município expresso em \%.

Normalização e Avaliação segundo Costa (2008) - Escala de avaliação para o indicador uso misto (Tabela 4). 
Tabela 4: Escala de avaliação do uso misto.

\begin{tabular}{|l|l|}
\hline Score & $\begin{array}{l}\text { Valores de Referência } \\
\text { Porcentagem da área urbana do município onde é permitido/incentivado o } \\
\text { uso misto do solo com atividades compatíveis entre si e com o uso } \\
\text { residencial }\end{array}$ \\
\hline 1,00 & Mais de $75 \%$ \\
\hline 0,75 & $75 \%$ \\
\hline 0,50 & $50 \%$ \\
\hline 0,25 & $25 \%$ \\
0,00 & $\begin{array}{l}0 \\
\text { A legislação urbanística municipal não permite o uso misto do solo, } \\
\text { determinando zonas de uso exclusivamente residencial, comercial, } \\
\text { industrial ou institucional, resultando em intensa setorização da área urbana }\end{array}$ \\
\hline
\end{tabular}

Fonte: Costa, (2008).

Escala de Avaliação da variável - Para a construção da "Árvore de Avaliação Forma Urbana”, a escala de avaliação da variável característica do uso do solo urbano será considerada da seguinte forma:

- Baixo uso misto: de 0 a 50\% da área analisada é permitido/incentivado o uso misto do solo com atividades compatíveis entre si e com uso residencial - (1).

- Médio uso misto: de 50 a $75 \%$ da área analisada é permitido/incentivado o uso misto do solo com atividades compatíveis entre si e com uso residencial - (2).

- Alto uso misto: em mais de $75 \%$ da área analisada é permitido/incentivado o uso misto do solo com atividades compatíveis entre si e com uso residencial - (3).

Observações: quanto mais se estimular o uso misto dentro de determinada área urbana, melhor será o desempenho da mobilidade sustentável.

\section{iii. Continuidade (vazios urbanos)}

A continuidade é avaliada por meio do indicador "Vazios Urbanos".

Relevância - De acordo com Costa (2008), a existência de áreas vazias ou desocupadas na área urbana revela incapacidade do município sobre os processos de uso e ocupação do solo urbano. Vazios urbanos, espalhamento da cidade e baixas densidades guardam estreita relação. Quanto menor a densidade, maior a expansão horizontal e, como consequência, maiores são as distâncias a serem percorridas nas viagens diárias (Ministério das Cidades, 2007). Maior quantidade de vazios urbanos implica a descontinuidade do tecido urbano, criando espaços mais fragmentados e de difícil locomoção.

Em termos sociais, os vazios urbanos contribuem para acentuar a segregação sócio espacial e a iniquidade, na medida em que crescem os loteamentos residenciais nas zonas periféricas das cidades para atender à população de baixa renda. Em termos econômicos, a existência de 
áreas vazias implica impactos nos valores dos terrenos, aumento dos custos de transporte e uso pouco eficiente da infraestrutura implantada. Em termos ambientais, os vazios urbanos relacionam-se com espalhamento e descontinuidade do tecido urbano e, em consequência disso, há uma perda da qualidade ambiental das cidades, já que a manutenção de espaços vazios urbanos resulta na utilização de áreas afastadas e desprovidas de infraestrutura para absorção do crescimento urbano, causando a destruição de áreas verdes e habitats naturais (Costa, 2008).

Definição - Porcentagem de áreas que se encontram vazias ou desocupadas na área urbana em análise.

Unidade de medida - Porcentagem de área urbana.

Dados de Base - Base georreferenciada ou base cartográfica digital do município, fotos aéreas (Google Earth), levantamento das áreas vazias na área urbana.

Fonte de Dados - Prefeitura Municipal (secretarias de planejamento, de urbanismo, etc).

Método de Cálculo - O indicador é calculado com auxílio do Sistema de Informações Geográficas (SIG). Na base georreferenciada e/ou base cartográfica, é necessário delimitar a área efetivamente urbanizada. A área urbana deve ser calculada em $\mathrm{Km}^{2}$ e devem ser identificados lotes e glebas vazias. Áreas de proteção ambiental, parques, áreas de lazer ou recreação não devem ser considerados neste indicador. $O$ indicador é obtido por meio do quociente entre a área total de vazios urbanos (dentro da área analisada) e a área urbana analisada expressa em $\mathrm{Km}^{2}$.

Normalização e Avaliação segundo Costa (2008) - Escala de avaliação para o indicador vazio urbano (Tabela 5).

Tabela 5: Escala de avaliação para o indicador vazio urbano.

\begin{tabular}{|l|l|}
\hline Score & $\begin{array}{l}\text { Valores de Referência } \\
\text { Porcentagem da área urbana do município vazia ou desocupada. }\end{array}$ \\
\hline 1,00 & Até $10 \%$ \\
\hline 0,75 & $20 \%$ \\
\hline 0,50 & $30 \%$ \\
\hline 0,25 & $40 \%$ \\
\hline 0,00 & $50 \%$ ou mais \\
\hline
\end{tabular}

Fonte: Costa, (2008).

Escala de Avaliação da variável - Para a construção da "Árvore de Avaliação Forma Urbana" a escala de avaliação da variável vazio urbano será considerada da seguinte maneira:

- Quantidade alta de vazios na área em análise: 50\% ou mais da área analisada vazia ou desocupada - (1); 
- Quantidade média de vazios na área em análise: entre 50\% e 20\% da área analisada vazia ou desocupada - (2);

- Quantidade baixa de vazios dentro da área urbana em análise: menos que 20\% da área analisada vazia ou desocupada - (3).

Observações: quanto menor o índice de vazios dentro da área de análise, melhor será o desempenho da mobilidade sustentável.

\section{iv. Características do desenho urbano: Integração Global (SE)}

Relevância - O desenho urbano é um campo disciplinar relevante para os estudos da cidade, conforme explicitado no capítulo anterior. Em função disso, pode ser avaliado considerando objetivos diversificados, a depender do campo teórico que se pretenda investigar. A análise das características do desenho urbano será relativa à malha viária para avaliar o potencial de movimento, recaindo sobre a "acessibilidade" ou integração, pautada no entendimento da Teoria da Lógica Social do Espaço, conforme se verá adiante.

A malha viária urbana, segundo Costa (2008), é a infraestrutura que possibilita o deslocamento de pessoas e bens, ampliando a acessibilidade aos serviços e atividades econômicas, possibilitando as relações sociais e maior dinamismo urbano.

A configuração da rede viária seja ela ortogonal, "orgânica", dentre outras, tem influência sobre as distâncias de viagem e a articulação de espaços urbanos mais acessíveis que permitam o deslocamento de pessoas e bens, fato este que traz efeitos positivos em termos sociais e econômicos para mobilidade urbana. Para a perspectiva ambiental, a rede viária tem impactos sobre dois aspectos distintos: ao mesmo tempo em que pode permitir a conectividade entre áreas da cidade, pode, em função de suas características configuracionais, resultar em segregação do espaço urbano e isolamento de comunidades.

Dados de Base - Base georreferenciada ou base cartográfica digital do município.

Fonte de Dados - Prefeitura Municipal (secretarias de planejamento, de urbanismo, etc).

Método de Cálculo ou Teoria utilizada - Teoria da Lógica Social do Espaço, Análise Sintática do Espaço ou Sintaxe Espacial (SE): mapa axial. 
O objetivo principal da $\mathrm{SE}^{26}$ é estudar as relações entre espaço e sociedade (vista como um sistema de possibilidade de encontro), por meio da leitura da configuração. A configuração urbana é entendida como o conjunto de relações de interdependência dos elementos componentes de um determinado sistema. Nesse caso, as cidades, considerando-se sua malha viária: a premissa permite a investigação da cidade de acordo com suas articulações. Entre as medidas possíveis da análise sintática, destacam-se as de integração global e local, sinergia, inteligibilidade, conectividade, compacidade ${ }^{27}$.

Para esta pesquisa, utilizou-se a variável integração global. A integração global/local, também conhecida como índice de acessibilidade topológica ou de permeabilidade, é a principal variável da SE e indica o nível de integração entre as várias partes do sistema de estudo, neste caso reduzido às linhas do respectivo mapa de axialidade (Medeiros, 2013). Ela é útil na previsão de fluxos de pedestres e veículos e no entendimento da lógica de localização de usos urbanos e dos encontros sociais (cf. Holanda, 2002; Medeiros, 2013; Barros,2014). De modo geral a integração revela como é fácil se deslocar a partir de cada linha para qualquer outra do sistema.

A integração pode ser visualizada por meio de uma análise gráfica que converte a escala numérica para uma escala cromática, de modo que as linhas mais integradas são apresentadas em cores quentes (tendentes ao vermelho), e as mais segregadas - são dispostas em cores mais frias (tendentes ao azul escuro). Segundo Ribeiro (2008), por meio do mapa axial processado, é possível identificar as áreas do sistema que estão mais isoladas (mais segregadas) ou mais integradas, em relação ao sistema global ou local. Em geral, é nas vias mais integradas que se encontram uma maior circulação de pessoas e concentração de veículos, comércio e serviços. Esta informação facilita a compreensão da articulação do desenho urbano, possibilitando avaliar a acessibilidade e a articulação da malha viária.

Para a obtenção da variável integração, devem ser seguidas as etapas abaixo:

\footnotetext{
${ }^{26}$ A Teoria da Sintaxe Espacial (SE) teve seu início na década de 1970, por meio de trabalhos publicados por Hillier e Leaman. Porém, foi com o livro The Social Logic of Space, publicado por Hillier e Hanson em 1984, que a teoria ganhou contornos mais específicos e uma base conceitual integrada. O livro também trazia referência a pesquisas empíricas já utilizando o método. No Brasil, as pesquisas concentram-se nas universidades UFRN, UFPE, UnB, UFSC e UFRGS.

${ }^{27}$ Conceitos das principais variáveis da SE estão disponíveis em Medeiros, (2013): A sinergia consiste no grau de sincronia entre os valores de integração global e local, onde se avalia a dependência de uma variável em relação à outra. Inteligibilidade corresponde à correlação entre a conectividade e o valor de integração global, indicando o grau de dependência de uma variável em relação à outra. A conectividade de uma linha axial é a quantidade de linhas que a interceptam. Linhas com alta conectividade tendem a ter um papel importante, uma vez que potencialmente promovem acesso a um grande número de outras linhas axiais. A compacidade pode ser obtida desenhando um polígono que circunscreve o mapa axial, esse polígono pode ser convexo ou irregular tangenciando o mapa (os limites do polígono coincidem com os limites do mapa). Com a área do polígono basta trabalhar a razão entre a medida "quantidade de linhas" ou "comprimento total de linhas" em Km pela área total do polígono.
} 
- Representação Linear: A representação linear consiste na construção de linhas sobre o leito das vias de uma determinada base cartográfica (a menor quantidade das maiores linhas), o que resultará no mapa axial. O mapa axial é a maneira de representação configuracional que revela a acessibilidade da trama existente por meio de uma escala cromática ou espessura de linha, quando considerada a variável integração global.

- Processamento das variáveis configuracionais: a partir da elaboração da representação linear, parte-se para análise dos eixos no software Depthmap. Nele, por meio da conectividade, são geradas as variáveis configuracionais, entre elas a integração global;

- Correlação: a última etapa contempla a correlação dessa variável com as demais variáveis; no caso da tese, a etapa será desenvolvida na árvore de avaliação forma urbana.

Avaliação - Escala de avaliação para o indicador Integração Global:

Aqui será utilizada a variável Integração Global como um indicador para o desenho urbano. A interpretação da medida resulta de possibilidade de quantificação, por meio do estudo de Medeiros (2013), o que subsidiou a escala de avaliação para esta variável. Medeiros (2013) investigou de que maneira a leitura da cidade, conforme a sua configuração, poderia trazer respostas sobre os espaços urbanos, considerando as variáveis configuracionais, incluindo a de Integração Global. A amostra do estudo considerou 44 cidades brasileiras, selecionadas a partir de critérios demográfico e patrimonial. Além disso, para confronto, foram utilizados ainda dados de 120 cidades do mundo, formando um banco de dados com 164 cidades.

Para este estudo e composição da árvore de avaliação forma urbana, consideraram-se os indicadores obtidos para as 44 cidades brasileiras (Cf. Medeiros, 2013 p. 390), assumindose o menor e maior valores obtidos, que são respectivamente 0,199 e 1,458, conforme ilustra Figura 22 e dividindo em três escalas de análise, a saber:

- Baixa Integração: faixa de valores entre 0,199 a 0,619

- Média Integração: faixa de valores entre 0,620 a 1,038

- Alta Integração: faixa de valores entre 1,039 a 1,458 


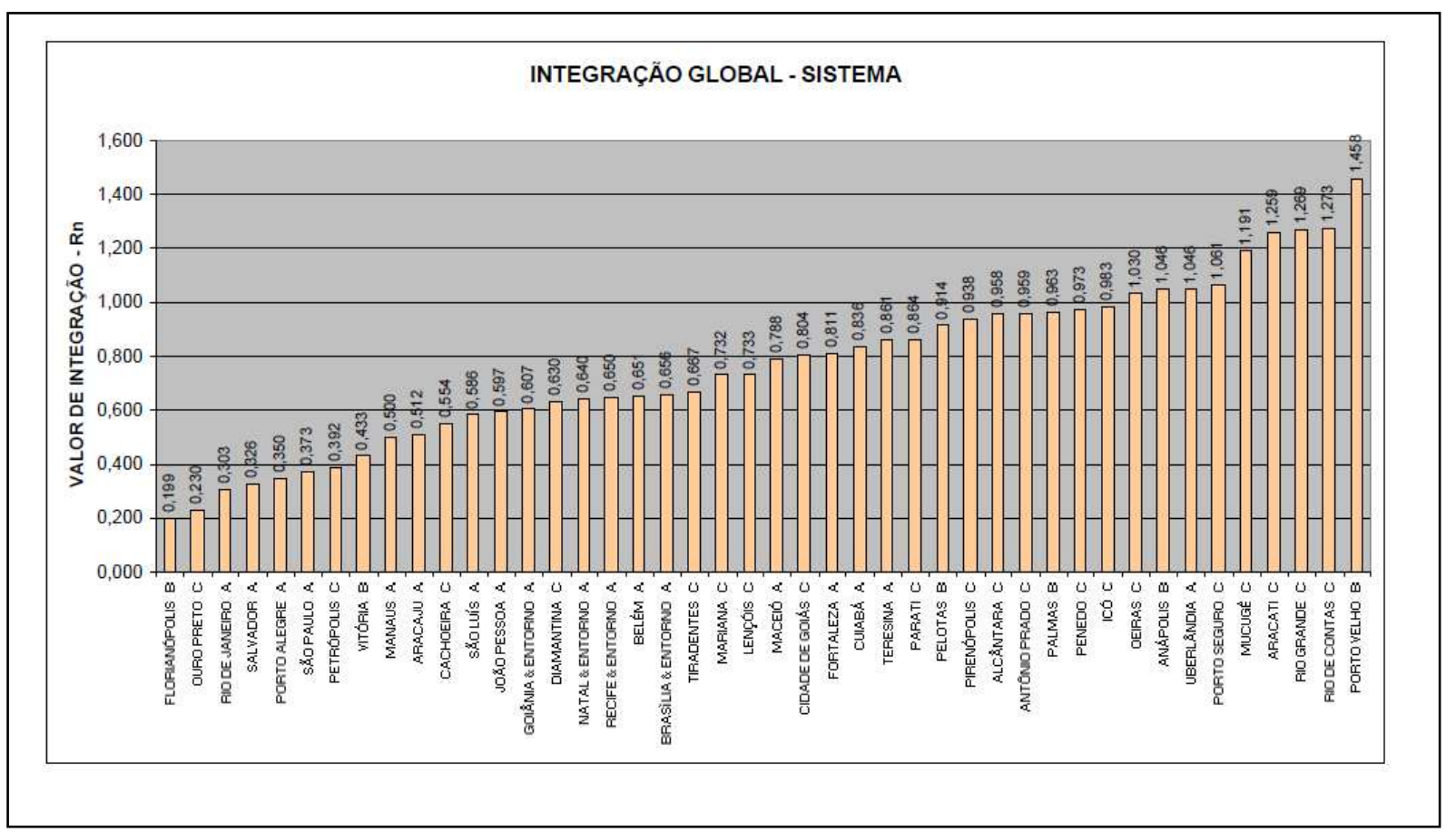

Figura 22: Valores médios de integração obtidos para as 44 cidades brasileiras. Fonte: Medeiros, (2013).

Importa dizer que a alta integração será considerada como um aspecto positivo, tendo em conta que uma via de maior integração é considerada potencialmente mais acessível ou permeável, ou seja, torna-se mais fácil alcançá-la de qualquer outro ponto da cidade. A lógica é inversa para a menos integrada. Ao se considerar um alto potencial de acessibilidade como um fator positivo na árvore de avaliação da forma urbana, pretende-se identificar um desenho urbano que gera maior mobilidade ou maior potencial de movimento.

\subsubsection{Agregação das variáveis do Eixo de Análise I - Árvore de Avaliação Forma Urbana}

A árvore de avaliação foi desenvolvida considerando todas as variáveis que iriam compor este eixo de análise (Figura 23), bem como suas respectivas escalas de avaliação, conforme já descritas no item anterior. Importa saber que a proposta da árvore levou em consideração três aspectos:

i. Hierarquia das variáveis na árvore: A escolha da densidade urbana como elemento preponderante na hierarquia deu-se pelo fato de que, ao analisar o referencial teórico sobre o tema, a variável aparece como elemento que traz implicações significativas para o planejamento e desenho urbano. Conforme destacam Acioly e Davidson (1998), “as intervenções urbanas e projetos habitacionais que pretendam inserir princípios de desenvolvimento sustentável demandam atenção especial para o planejamento físico espacial, dentro do qual a densidade ocupa uma posição de destaque”. Na sequência, tem-se uso do solo urbano, vazios urbanos e desenho urbano. A decisão, em relação a essa hierarquia pode 
variar de acordo com experiência e perspectivas do grupo que irá avaliar a área em questão, neste caso, as considerações recaíram sobre o referencial teórico explorado na tese.

ii. Operadores lógicos (álgebra booleana): os operadores lógicos utilizados na árvore foram “e/ou”, conforme ilustra Figura 24; e eles servem para agregar as variáveis dispostas no eixo de análise forma urbana. O operador "OU” é conhecido como adição lógica e o operador "E" como produto lógico. Para compreender a função dos operadores lógicos, primeiro é importante verificar que a árvore possibilita que sejam percorridos vários caminhos, e estes levarão para um nível de desempenho que pode varia, neste caso de I a IV (menor ao maior desempenho). Pode-se fazer a leitura da árvore da seguinte forma: densidade populacional (1) OU (2), supondo que a avaliação desta variável esteja no nível 2, segue-se para análise da próxima variável, "E” Uso do Solo Urbano que oferece três possibilidades (1) OU (2) OU (3) “E”" Vazios Urbanos que oferece três possibilidades (1) OU (2) OU (3), até se chegar no último nível “E” Desenho Urbano que também oferece três possibilidade (1) OU (2) OU (3), levando para quatro níveis de desempenho (I) OU (II) OU (III) OU (IV). Pela leitura do diagrama proposta na Figura 24, tem-se que Densidade populacional (2), "E" Uso Solo Urbano (1) “E” Vazios Urbanos (2) "E”' Desenho Urbano (1), levam para um nível de desempenho "II" em relação a forma urbana. Pelo prosseguimento da leitura do diagrama tem-se que a situação de menor desempenho em relação a mobilidade sustentável encontra-se em áreas com baixa densidade, pouco incentivo ao uso misto, grande quantidade de vazios e um desenho urbano caracterizado por eixos com menor potencial de integração, isto é, malha viária pouco acessível, o contrário se verifica em relação a área com maior desempenho. Importa saber que existem outros caminhos que podem ser percorridas, todos dependerão da avaliação individual para cada variável proposta na árvore.

iii. Elaboração da proposta das árvores: para se chegar na proposta da árvore de avaliação de forma urbana, assim como na de transporte e circulação, foram desenvolvidos e testados vários modelos. A proposta do arranjo da árvore, bem como de seus caminhos e níveis depende do grupo que irá avaliar a área em questão, da experiência profissional e dos objetivos que se pretende alcançar em relação ao planejamento urbano e potencial da mobilidade sustentável. Neste caso, as árvores foram elaboradas pela autora do trabalho, que considerou 0 referencial teórico descrito na tese. 


\title{
Árvore de Avaliação com os Elementos da Forma Urbana
}

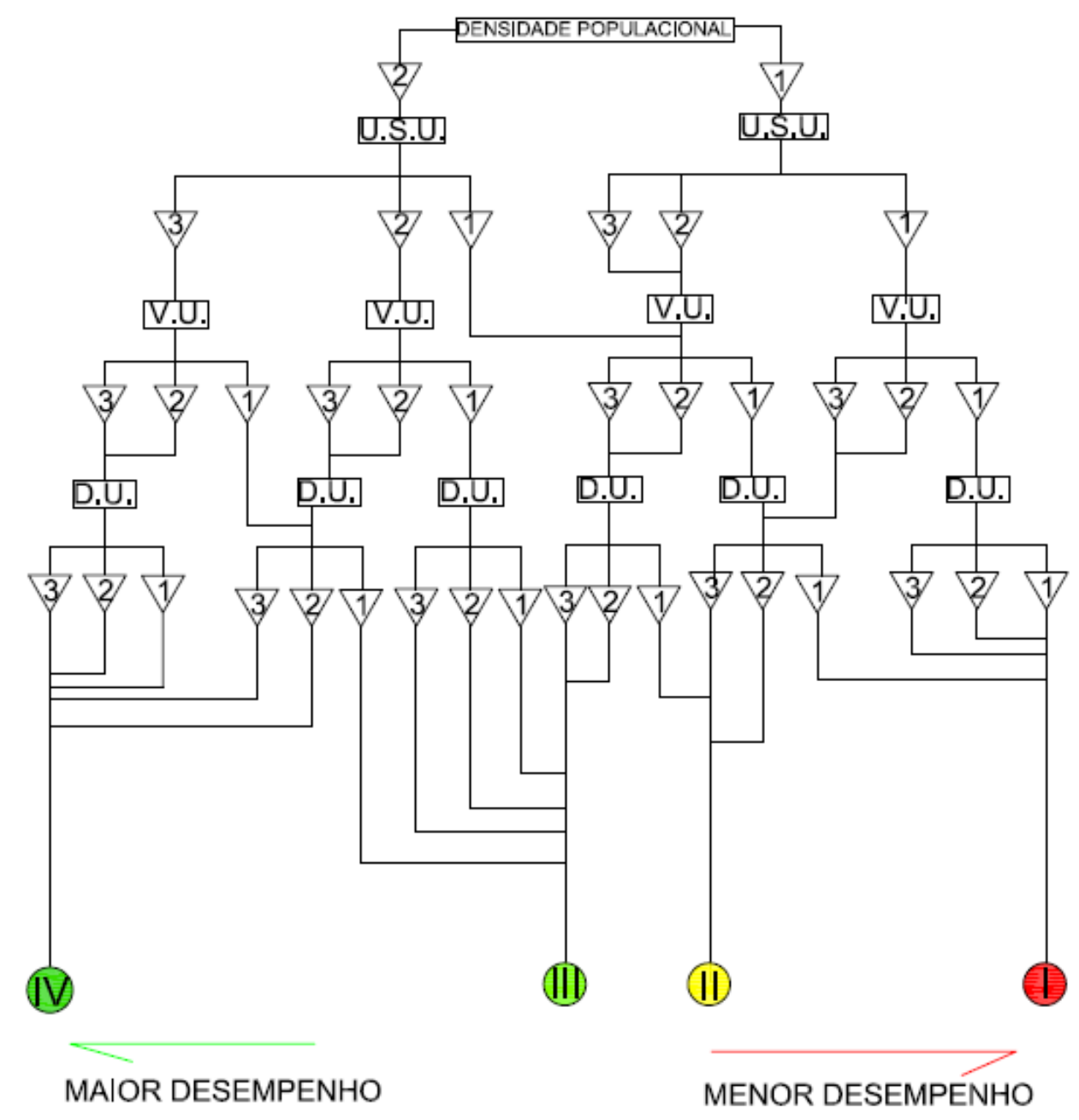

\author{
I.1 Caracteristlcas da Densidade \\ (1) Balxa: $<50 \mathrm{Hab} / \mathrm{Hac}$ \\ (2) Alta: > $50 \mathrm{Hab} / \mathrm{Hac}$
}

1.2 Caracteristlcas do Uso do solo urbano-U,S.U.

(1) Balxo uso mlsto: $<50 \%$ da área em anállse é permltldo/nncentlvado o uso mlsto com atlvldades compativels entre sl.

(2) Médlo uso mlsto; entre $50 \%$ e $75 \%$ da área em anállse é

permltido/lncentlvado o uso mlsto com atlvldades compatívels entre sl.

(3) Alto uso mlsto: > 75\% da área de anállse é permltido/lncentlvado o uso mlsto com atlvldades compativels entre sl.

I.3 Contlnuldade - Vazlos Urbanos - V.U,

(1) Quantldade alta de vazlos: $>50 \%$ da área em anállse vazla ou desocupada,

(2) Quantldade médla de vazlos entre $50 \%$ a $20 \%$ da área em análse vazla ou

desocupada.

(3) Quantldade balxa de vazlos: $<20 \%$ da área em anállse vazla ou desocupada.

I.4 Caracteristlcas do Desenho urbano: Integração Global - D.U.

(1) Balxa Integração:valor médlo da varlável Integraçăo Global: < 0,619;

(2) Médla Integração: valor médlo da varlável Integração Global: entre 0,619 a

1,038 ;

(3) Alta |ntegraçäo; valor médlo da varlável Integração Global > 1,038 


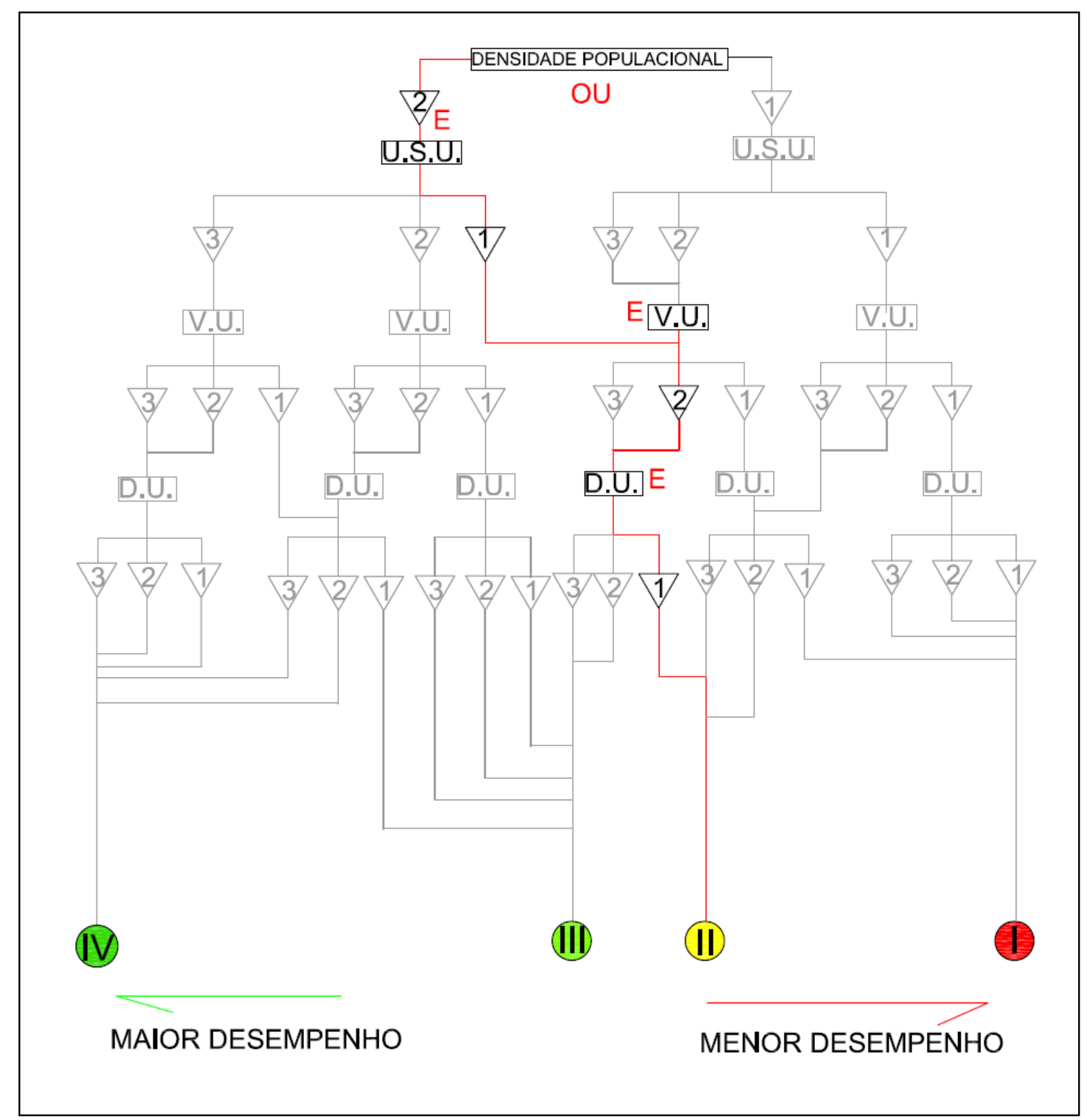

Figura 24: Exemplo de um dos caminhos percorridos na Árvore de Avaliação da Forma Urbana e utilização da lógica matemática.

\subsubsection{Decomposição do sistema "Transporte e Circulação"}

Para avaliação dos elementos de transporte e circulação, ficaram estabelecidas no item, as seguintes variáveis para o Eixo de Análise II (cf. 2.6.2 Capítulo 2):

i. extensão da rede de transporte público;

ii. acessibilidade ao transporte público (cobertura do transporte público);

iii. vias para pedestres;

iv. extensão e conectividade de ciclovias. 
Para cada variável tem-se um correspondente indicador na tabela de indicadores proposta por Costa (2008). Por meio dessa escala de avaliação (cf. Costa, 2008), definiu-se uma nova escala dividindo o score desses indicadores em três níveis de avaliação para cada variável, estabelecendo faixas de análise que podem ser classificadas em: alto, médio e baixo. A escala é crescente à medida que se cria uma situação favorável para mobilidade sustentável. A definição das escalas de avaliação para cada variável será descrita a seguir.

\section{i. Extensão da rede de transporte público}

Relevância - Segundo Costa (2008), a disponibilidade e cobertura de transporte público é fator essencial para mobilidade sustentável. A ausência de transporte público de qualidade estimula o uso do transporte individual, gerando efeitos negativos de ordem social, econômica e ambiental para as cidades. Em termos sociais, a disponibilidade de transporte público é fator de inclusão social e proporciona acesso às atividades que a cidade oferece. Em termos econômicos, a extensão da infraestrutura e a disponibilidade de serviços de transporte público têm influência direta sobre a valorização de determinadas áreas urbanas e sobre a dinâmica e desenvolvimento econômico, ampliando o acesso aos serviços e atividades urbanas. Em termos ambientais, contribui para a redução do volume de veículos nas vias; como consequências, têm-se a redução dos congestionamentos e da emissão de gases poluentes na atmosfera. No entanto, as redes de transporte público podem favorecer a fragmentação e a segregação urbana, especialmente no caso em que ocorre a implantação de corredores de ônibus, sistema sobre trilhos, dentre outros. Tais elementos exigem um planejamento adequado na inserção urbana, principalmente na articulação e interface com os demais modos de transporte.

Definição - Extensão total da rede de transporte público em relação à extensão total do sistema viário urbano.

Unidade de Medida - Porcentagem (\%).

Dados de Base - Base cartográfica do município georreferenciada, rotas fixas de ônibus e micro-ônibus operadas na área urbana do município; linhas de VLT, linhas de trem urbano e metropolitano, linhas de bonde e metrô, linhas, rotas, percursos de outros modos de transporte disponíveis na cidade (monotrilho, teleférico, balsas, barcas, etc.), extensão total do sistema viário urbano. 
Fonte de Dados - Prefeitura Municipal (secretarias de transportes, de mobilidade, de infraestrutura, de planejamento, etc.).

Método de Cálculo - Na base cartográfica do município (digital ou impressa) deve ser identificada a rede de transporte público em todas as suas modalidades. Para o levantamento da extensão da rede, devem ser consideradas:

- Extensão de rotas fixas de ônibus e micro-ônibus, obtidas por meio das operadoras e órgãos de gestão de transportes. As informações poderão ser trabalhadas em planilhas eletrônicas ou por meio de Sistemas de Informações Geográficas e Desenho Assistido por Computador. Recomenda-se que sejam mapeadas em bases cartográficas todas as rotas de transporte público por ônibus, micro-ônibus e vans existentes no município. A extensão total da rede deve ser obtida por meio do somatório do comprimento dos segmentos de vias cobertos pelo serviço. O simples somatório das extensões das linhas de ônibus informado pelas operadoras poderá gerar divergências, uma vez que mais de uma linha poderá atender um segmento de via, superestimando assim, a cobertura da rede de transporte;

- Extensão de linhas de trem urbano e de subúrbio. No caso das linhas se estenderem por outros municípios da Região Metropolitana, mensurar apenas trechos que se desenvolvem no município em análise. Recomenda-se também seu mapeamento em bases cartográficas para facilitar a identificação de todos os trechos e sua mensuração. No entanto, a extensão da via permanente pode ser obtida com grande precisão por meio de empresas e órgãos operadores do serviço, ao contrário dos dados referentes à rede de ônibus urbano, onde pode haver sobreposição;

- Extensão das linhas de trólebus, VLT e bonde. Recomenda-se o mapeamento das linhas em bases cartográficas; para as linhas de metrô, devem ser considerados os trechos subterrâneos, em superfície e elevados. No caso das linhas se estenderem por municípios da Região Metropolitana, mensurar apenas trecho que se desenvolve no município. Recomenda-se também o mapeamento das linhas em bases cartográficas;

- Extensão de linhas e rotas de outros modos de transporte (monotrilho, teleférico, balsas, barcas, etc). No caso de existirem serviços regulares de balsas ou barcas, devese obter uma estimativa da extensão percorrida em quilômetros.

O indicador é obtido segundo a razão entre o somatório da extensão da rede de todos os modos indicados e a extensão total do sistema viário urbano, expresso em porcentagem 
(\%). Na ausência de dados que possibilitem o cálculo preciso do indicador, sua avaliação deve ser feita por técnico ou gestor com conhecimento da questão.

Normalização e Avaliação segundo Costa (2008) - Escala de avaliação para o indicador extensão da rede de transporte público (Tabela 6).

Tabela 6: Escala de avaliação para o indicador extensão da rede de transporte público.

\begin{tabular}{|l|l|}
\hline Score & $\begin{array}{l}\text { Valores de Referência } \\
\text { Extensão da rede de transporte público em relação a extensão do sistema } \\
\text { viário }\end{array}$ \\
\hline 1,00 & $100 \%$ ou superior \\
\hline 0,75 & $80 \%$ \\
\hline 0,50 & $60 \%$ \\
\hline 0,25 & $40 \%$ \\
\hline 0,00 & Até $20 \%$ \\
\hline
\end{tabular}

Fonte: Costa, (2008).

Escala de Avaliação da variável - Para a construção da "Árvore de Avaliação Elementos de Transporte e Circulação", a escala de avaliação da variável extensão da rede de transporte público será considerada da seguinte forma:

- Quantidade baixa de extensão da rede de transporte público: 40\% ou menos da extensão da rede de transporte público em relação ao sistema viário da área analisada $-(1)$

- Quantidade média de extensão da rede de transporte público: entre $40 \%$ e $80 \%$ da extensão da rede de transporte público em relação ao sistema viário da área analisada (2);

- Quantidade alta de extensão da rede de transporte público: Acima de $80 \%$ da extensão da rede de transporte público em relação ao sistema viário da área analisada - (3).

Observações: quanto maior a extensão de transporte público dentro da área de análise, melhor será o desempenho da mobilidade sustentável.

\section{ii. Acessibilidade ao Transporte Público (Cobertura do Transporte Público)}

Relevância - De acordo com Costa (2008), a acessibilidade ao sistema de transporte público contribui para o aumento dos índices de mobilidade da população. No campo econômico, a proximidade a redes de transporte tem efeito sobre o valor dos imóveis e constitui-se em instrumento de atração de atividades econômicas. No campo ambiental, a utilização do transporte público reduz a circulação dos veículos privados, permitindo uso racional do sistema viário e contribui também para redução da poluição atmosférica. 
Definição - Porcentagem da população urbana residente na área de cobertura de um ponto de acesso aos serviços de transporte público, considerando todos os modos disponíveis.

Unidade de Medida - Porcentagem da população \%.

Dados de Base - base cartográfica georreferenciada do município, incluir os setores censitários ou outra unidade de análise territorial; número de habitantes por unidade de análise territorial; número médio de moradores por unidade de análise territorial; localização dos pontos de parada de ônibus, terminais de integração, estações de trem, metrô, pontos de embarque em transporte hidroviário e outros pontos de acesso aos sistemas de transporte público.

Fonte de Dados - IBGE, Prefeitura Municipal (Secretarias de obras, de viação, de infraestrutura, de transportes, de mobilidade ou de planejamento), empresas de cartografia e geoprocessamento, concessionárias de serviços públicos.

Método de Cálculo segundo Costa (2008) - O método de cálculo do indicador depende das ferramentas e informações disponíveis. Costa (2008) indica dois métodos de cálculo: o primeiro, considerando a disponibilidade de Sistemas de Informações Geográficas (SIG), o segundo tendo em conta a possibilidade de uso de ferramentas de Desenho Assistido por Computador (CAD). O Sistema de Informações Geográficas mostra-se mais adequado para o cálculo deste indicador, uma vez que agrega, em uma única base, dados geográficos e alfanuméricos, permitindo obter mais facilmente o valor correspondente à população atendida por cada ponto e o valor total. No caso de utilização de ferramentas de Desenho Assistido por Computador, deve ser combinado o uso de planilhas eletrônicas para facilitar o processo de cálculo.

Utilizando Sistemas de Informações Geográficas, devem ser desenvolvidos os seguintes procedimentos:

- Na base georreferenciada do município, deve ser delimitada, com maior precisão possível, a área efetivamente urbanizada (domicílios urbanos). No caso de o limite da área urbana do município ter sido estabelecido por meio de Lei Municipal, deve ser adotada esta poligonal limite para cálculo do indicador. A base georreferenciada deve conter informações sobre o número de domicílios e população residente por área (setor censitário, lote, quadra, etc) para permitir o cálculo do indicador;

- Criar uma base de pontos, identificando todos os locais de acesso ao sistema de transporte público de passageiros; 
- Delimitar a área de influência (buffer) de cada ponto de acesso ao sistema, correspondendo a um círculo com centro no respectivo ponto e raio de 300 ou 500 metros. O raio de 300 metros deve ser delimitado no caso de pontos de ônibus, microônibus e vans. Já o raio de 500 metros deve ser utilizado para estações e terminais de bonde, trem, metrô, balsas, e para os demais modos de transporte de alta capacidade disponíveis na cidade. Deve-se tomar cuidado para não sobrepor as áreas referentes a cada ponto, implicando, assim, em dupla contagem da população residente. Neste caso, recomenda-se que todas as áreas obtidas sejam unidas, formando uma mancha única que caracterize a área total de cobertura do sistema de transporte coletivo;

- Com base nos dados dos setores censitários fornecidos pelo IBGE ou do cadastro de domicílios fornecido pelas concessionárias de serviços públicos, obtém-se o valor correspondente à população atendida por cada ponto, contida na área de influência delimitada para o mesmo. Pode-se ainda obter o número total de domicílios ou pessoas residentes na área total de cobertura do sistema de transporte público, correspondente à mancha resultante da fusão das áreas de influência de cada ponto identificado. No caso de se dispor somente do número de domicílios na área em estudo, recomenda-se conseguir dados referentes ao número médio de moradores por domicílio e estimar assim o número total de pessoas residentes na área.

Utilizando pacotes de Desenho Assistido por Computador, devem ser desenvolvidos os seguintes procedimentos:

- Na base cartográfica digital do município deve ser delimitada, com maior precisão possível, a área efetivamente urbanizada (domicílios urbanos). Para tornar possível o cálculo do indicador, esta base deve conter dados sobre o número de domicílios ou população residente por área (setor censitário, lote, quadra, etc);

- Identificar (pontuar) na base cartográfica todos os locais de acesso ao sistema de transporte público de passageiros;

- Para cada ponto identificado, delimitar sua área de influência, correspondente a um círculo com centro no respectivo ponto e raio de 300 ou 500 metros, conforme especificado. No caso de se utilizar informações de população por setor censitário, deve ser verificada a parcela de cada setor contida na área de influência do ponto, e estabelecida uma proporção para cálculo do número de habitantes atendidos (por exemplo, se a área de influência do ponto corresponde a 1/4 da área do setor censitário, deve ser considerada somente $1 / 4$ da população do respectivo setor). No caso de 
domicílios contidos na área de influência de mais de um ponto, estes devem ser computados somente uma vez, para um único ponto. Nesta etapa, devem ser utilizadas planilhas eletrônicas para auxiliar no cálculo do indicador.

O indicador é oriundo da divisão do valor total de população atendida, obtido por meio de um dos modos indicados acima, pelo número total de habitantes na área urbanizada (área em estudo), com resultado expresso em porcentagem (\%).

Normalização e Avaliação do indicador conforme Costa (2008) - Escala de avaliação para o indicador acessibilidade ao transporte público (Tabela 7).

Tabela 7: Escala de avaliação para o indicador acessibilidade ao transporte público.

\begin{tabular}{|l|l|}
\hline Score & $\begin{array}{l}\text { Valores de Referência } \\
\text { Porcentagem da população urbana residente na área de cobertura de } \\
\text { pontos de acesso ao transporte público }\end{array}$ \\
\hline 1,00 & $100 \%$ \\
\hline 0,75 & $77,5 \%$ \\
\hline 0,50 & $55 \%$ \\
\hline 0,25 & $32,5 \%$ \\
\hline 0,00 & Até $10 \%$ \\
\hline
\end{tabular}

Fonte: Costa (2008)

Escala de Avaliação da variável - Para a construção da "Árvore de Avaliação Elementos de Transporte e Circulação", a escala de avaliação da variável acessibilidade ao transporte público será considerada da seguinte forma:

- Baixa acessibilidade ao transporte público: até 32,5\% da população urbana reside na área de cobertura de pontos de acesso ao transporte público - (1);

- Média acessibilidade ao transporte público: entre 32,5\% e 775,\% da população urbana reside na área de cobertura de pontos de acesso ao transporte público - (2);

- Alta acessibilidade ao transporte público: acima de 77,5\% da população urbana reside na área de cobertura de pontos de acesso ao transporte público - (3).

Observações: quanto maior a cobertura do transporte público dentro da área de análise, melhor será o desempenho da mobilidade sustentável.

\section{iii. Vias para pedestres}

Relevância - De acordo com Costa (2008), incentivar políticas para o uso de modos nãomotorizados é aspecto chave para obtenção da mobilidade sustentável. Em razão disso, as vias para pedestres devem atender requisitos de conforto e segurança. Em termos sociais, a provisão de vias para pedestre auxilia no convívio social, ampliando as relações de vizinhança. Em termos ambientais, aumenta o potencial dos deslocamentos a pé, contribuindo para qualidade ambiental urbana na medida em que auxilia na redução do consumo de 
combustíveis fosseis. A conectividade dos caminhos é um elemento importante, especialmente em áreas de grande circulação de pessoas, e a falta de conectividade da rede implica desconforto e insegurança, o que desestimula o deslocamento a pé.

Definição - Cobertura e conectividade da rede de vias para pedestre.

Unidade de Medida - Porcentagem de vias (\%) e grau de conectividade.

Dados de Base - Base cartográfica do município com infraestrutura viária (base de ruas vetorizada) ou base georreferenciada. Pode incluir imagens de satélite com resolução suficiente para identificação da infraestrutura viária; extensão do sistema viário, exceto sistemas sobre trilhos: vias expressas, arteriais, coletoras, locais, pavimentadas ou não, regularizadas ou não, na área urbana do município; rede de vias especiais para pedestres, incluindo:

i. Vias exclusivas para pedestres (calçadões);

ii. Vias com prioridade para a circulação de pedestres (com restrição de circulação de veículos em determinados períodos do dia);

iii. Rotas especiais de pedestres, relacionadas a pontos turísticos ou patrimônio histórico;

iv. Rampas e passarelas em vias públicas;

v. Calçadas que apresentem elementos de segregação física com o espaço destinado à circulação de veículos.

Fonte de Dados - Prefeitura Municipal (secretarias de obras, de infraestrutura, de transportes, de mobilidade ou de planejamento), órgãos, empresas e autarquias de trânsito e transportes.

Método de Cálculo segundo Costa (2008) - O cálculo do indicador consiste na determinação de um parâmetro de referência para a extensão e a cobertura da rede de caminhos para pedestres e na análise da conectividade da rede, gerando um score único que deve refletir as principais características do sistema viário urbano para o modo a pé. Para o cálculo da extensão/cobertura da rede de caminhos para pedestres, recomendam-se os seguintes procedimentos:

- Na base cartográfica do município, deve ser delimitada, com maior precisão possível, a área efetivamente urbanizada;

- O sistema viário deve ser inteiramente identificado e mensurado, com valores expressos em km;

- As vias especiais para pedestres devem ser identificadas na base cartográfica e sua extensão total mensurada, expressa em $\mathrm{km}$. Nesta etapa pode-se fazer uso de bases 
cartográficas digitais ou impressas, Sistemas de Informações Geográficas e de Desenho Assistido por Computador;

- O parâmetro é obtido por meio do quociente entre a extensão total de vias especiais para pedestres e a extensão total do sistema viário urbano, expresso em porcentagem $(\%)$.

O segundo parâmetro, relacionado à conectividade da rede, deve ser analisado com o auxílio de imagens aéreas ou levantamentos de campo. A conectividade é verificada com base nos seguintes aspectos:

- Manutenção das características físicas da via, tais como: largura, tipo de pavimento, sinalização vertical e horizontal;

- Ausência de barreiras físicas que impeçam ou restrinjam os deslocamentos, incluindo mobiliário urbano, arborização, bem como obstáculos impostos por estabelecimentos comerciais e de serviços;

- As interseções com vias de circulação de automóveis são em número reduzido e, quando existentes, são devidamente protegidas e sinalizadas, privilegiando os deslocamentos a pé;

- As distâncias de viagem feitas por caminhos e rotas de pedestres são próximas às distâncias efetivas entre dois pontos (distância em linha reta), indicando que os caminhos são diretos e com alta conectividade.

Com base nos dois elementos, deve ser identificado o respectivo score do indicador, associando diretamente os valores apresentados no quadro a seguir.

Normalização e Avaliação do indicador conforme Costa (2008) - Escala de avaliação para o indicador vias para pedestres (Tabela 8).

Tabela 8: Escala de avaliação para o indicador vias para pedestre.

\begin{tabular}{|l|l|}
\hline Score & Valores de Referência \\
\hline 1,00 & $\begin{array}{l}\text { Mais de } 25 \% \text { do sistema viário urbano é composto por vias especiais ou } \\
\text { preferenciais para pedestres e a rede apresenta alta conectividade }\end{array}$ \\
\hline 0,75 & $\begin{array}{l}\text { Mais de } 25 \% \text { do sistema viário urbano é composto por vias especiais ou } \\
\text { preferenciais para pedestres, porém, a rede apresenta baixa conectividade }\end{array}$ \\
\hline 0,50 & $\begin{array}{l}\text { Até } 25 \% \text { do sistema viário urbano é composto por vias especiais ou } \\
\text { preferenciais para pedestres e a rede apresenta alta conectividade }\end{array}$ \\
\hline 0,25 & $\begin{array}{l}\text { Até } 25 \% \text { do sistema viário urbano é composto por vias especiais ou } \\
\text { preferenciais para pedestres, porém, a rede apresenta baixa conectividade }\end{array}$ \\
\hline 0,00 & Não há no município vias especiais ou preferenciais para pedestres \\
\hline
\end{tabular}

Fonte: Costa (2008)

Escala de Avaliação da variável - Para a construção da "Árvore de Avaliação dos Elementos de Transporte e Circulação", a escala de avaliação da variável "vias para pedestre" será considerada da seguinte forma: 
- Baixa quantidade de vias para pedestres: Não há na área urbana delimitada para estudo vias especiais ou preferenciais para pedestres ou até $25 \%$ do sistema viária urbano são compostos por vias especiais ou preferenciais para pedestres e a rede apresenta baixa conectividade - (1)

- Média quantidade de vias para pedestres: Até $25 \%$ do sistema viário urbano é composto por vias especiais ou preferenciais para pedestre e a rede apresenta alta conectividade - (2)

- Alta quantidade de vias para pedestres: Mais de $25 \%$ do sistema viário urbano são compostos por vias especiais ou preferenciais para pedestres e a rede apresenta alta/baixa conectividade - (3)

Observações: quanto maior a quantidade, conectividade e acessibilidade de vias para pedestres dentro da área de análise, melhor será o desempenho da mobilidade sustentável.

\section{iv. Extensão e conectividade de ciclovias}

Relevância - Fomentar a utilização dos modos não-motorizados é um aspecto essencial para mobilidade sustentável. Porém, a infraestrutura deve ser adequada, proporcionando qualidade e segurança para os deslocamentos. A bicicleta é um modo de transporte acessível e barato, especialmente para população de baixa renda, e acarreta benefícios à saúde humana e qualidade de vida. Ampliar a oferta de rede de infraestrutura para os usuários de bicicleta pode permitir a democratização do espaço urbano. Em termos ambientais, o uso da bicicleta viabiliza uma melhoria da qualidade ambiental urbana, reduzindo o consumo de combustíveis fósseis e emissão de poluentes na atmosfera. Além disso, exige uma infraestrutura bem mais simples, menos onerosa e menos impactante do que a infraestrutura necessária para a circulação de veículos motorizados (COSTA, 2008).

Definição - Cobertura e conectividade da rede de vias para bicicleta.

Unidade de Medida - Porcentagem de vias (\%) e grau de conectividade.

Dados de Base - Base cartográfica do município com infraestrutura viária (base de ruas vetorizada) ou base georreferenciada. Pode incluir imagens de satélite com resolução suficiente para identificação da infraestrutura viária; extensão do sistema viário, exceto sistemas sobre trilhos: vias expressas, arteriais, coletoras, locais, pavimentadas ou não, regularizadas ou não, na área urbana do município; rede de vias especiais para uso da bicicleta, incluindo:

i. Ciclovia, entendida como faixa ou via segregada por barreira física; 
ii. Ciclofaixa, entendida como faixa de via destinada à bicicleta, delimitada por sinalização horizontal e/ou vertical;

iii. Passeios compartilhados com pedestres.

Fonte de Dados - Prefeitura municipal (Secretarias de obras, de viação, de infraestrutura, de transportes, de mobilidade ou de planejamento), órgãos, empresas e autarquias de trânsito e transportes.

Método de Cálculo - O cálculo do indicador consiste na determinação de um parâmetro de referência para a extensão e a cobertura da rede de caminhos para bicicleta e na análise da conectividade da rede, gerando um score único que deve refletir as principais características do sistema viário urbano para uso da bicicleta. Para o cálculo da extensão/cobertura da rede de caminhos para bicicleta, recomendam-se os seguintes procedimentos:

- Na base cartográfica do município, deve ser delimitada, com maior precisão possível, a área efetivamente urbanizada;

- O sistema viário deve ser inteiramente identificado e mensurado, com valores expressos em km;

- As vias especiais para bicicletas (ciclovias, ciclofaixas e passeios compartilhados) devem ser identificadas na base cartográfica e sua extensão total mensurada, expressa em km. Nesta etapa, pode-se fazer uso de bases cartográficas digitais ou impressas, Sistemas de Informações Geográficas e de Desenho Assistido por Computador.

O parâmetro é obtido pelo quociente entre a extensão total de ciclovias e ciclofaixas e a extensão total do sistema viário urbano, expresso em porcentagem (\%).

A conectividade da rede de ciclovias é definida com base em critérios qualitativos, definidos segundo a análise de imagens aéreas ou por meio de levantamentos de campo. A conectividade é verificada de acordo com os seguintes aspectos:

- Manutenção das características físicas e operacionais da ciclovia, tais como: largura, tipo de pavimento, sinalização vertical e horizontal;

- Ausência de barreiras físicas que impeçam ou restrinjam os deslocamentos;

- Continuidade, ou seja, existência de uma rede bem definida e contínua de ciclovias.

Com base na extensão e conectividade, deve ser identificado o respectivo score do indicador, associando diretamente os valores apresentados na tabela de normalização e avaliação.

Normalização e Avaliação do indicador conforme Costa (2008) - Escala de avaliação para o indicador extensão e conectividade de ciclovias (Tabela 9). 
Tabela 9: Escala de avaliação para o indicador extensão e conectividade de ciclovias.

\begin{tabular}{|l|l|}
\hline Score & Valores de Referência \\
\hline 1,00 & $\begin{array}{l}\text { Mais de } 25 \% \text { do sistema viário urbano apresenta ciclovias ou ciclofaixas e a } \\
\text { rede apresenta alta conectividade }\end{array}$ \\
\hline 0,75 & $\begin{array}{l}\text { Mais de } 25 \% \text { do sistema viário urbano apresenta ciclovias ou ciclofaixas, } \\
\text { porém, a rede apresenta baixa conectividade }\end{array}$ \\
\hline 0,50 & $\begin{array}{l}\text { Até } 25 \% \text { do sistema viário urbano apresenta ciclovias ou ciclofaixas e a } \\
\text { rede apresenta alta conectividade }\end{array}$ \\
\hline 0,25 & $\begin{array}{l}\text { Até } 25 \% \text { do sistema viário urbano apresenta ciclovias ou ciclofaixas, porém, } \\
\text { a rede apresenta baixa conectividade }\end{array}$ \\
\hline 0,00 & Não há no município nenhum trecho de ciclovias ou ciclofaixa \\
\hline
\end{tabular}

Fonte: Costa, (2008).

Costa (2008) sugere que, na ausência de dados que possibilitem o cálculo preciso do indicador, sua avaliação deve ser feita por técnico ou gestor com conhecimento da questão, com base na Tabela 9 .

Escala de Avaliação da variável - Para a construção da "Árvore de Avaliação dos Elementos de Transporte e Circulação" a escala de avaliação da variável "extensão e conectividade de ciclovias" será considerada da seguinte forma:

- Baixa quantidade de ciclovias: Quando não há na área urbana delimitada para estudo nenhum trecho de ciclovias ou ciclofaixa, ou até $25 \%$ do sistema viária urbano apresentam ciclovias ou ciclofaixas e a rede apresentar baixa conectividade - (1);

- Média quantidade de ciclovias: Até $25 \%$ do sistema viário urbano apresentam ciclovias ou ciclofaixas com alta conectividade - (2);

- Alta quantidade de ciclovias: Mais de $25 \%$ do sistema viário urbano apresentam ciclovias ou ciclofaixas e a rede tem alta/baixa conectividade - (3).

Observações: quanto maior a quantidade, conectividade e acessibilidade de ciclovias ou ciclofaixas dentro da área de análise, melhor será o desempenho da mobilidade sustentável.

\subsubsection{Agregação das variáveis do Eixo de Análise II - Árvore de Avaliação}

A árvore de avaliação foi desenvolvida considerando todas as variáveis que iriam compor este eixo de análise (Figura 25), bem como suas respectivas escalas de avaliação. Importa saber que a proposta da árvore levou em consideração os seguintes aspectos:

i. Hierarquia das variáveis na árvore: A leitura do diagrama do tipo "árvore" pode assim ser procedida pela variável "extensão da rede de transporte público", pois, ao se determinar a extensão da rede de transporte público é possível estabelecer as vias prioritárias por onde deve partir o planejamento para cobertura do transporte público (implantação de pontos de ônibus) assim como o planejamento e integração das redes de ciclovias/ciclofaixas 
e vias para pedestres, facilitando o acesso ao transporte público. Em virtude disso, a variável “Extensão da Rede de Transporte Público" aparece como elemento indutor para as demais variáveis ocupando a posição de maior destaque na árvore.

ii. Operadores lógicos (álgebra booleana): os operadores lógicos utilizados na árvore foram “e/ou", conforme ilustra Figura 26; e eles servem para agregar as variáveis dispostas no eixo de análise forma urbana. O operador "OU" é conhecido como adição lógica e o operador "E” como produto lógico. Para compreender a função dos operadores lógicos, primeiro é importante verificar que a árvore possibilita que sejam percorridos vários caminhos, e estes levarão para um nível de desempenho que pode varia, neste caso de I a IV (menor ao maior desempenho). Pode-se fazer a leitura da árvore da seguinte forma: Extensão da Rede de Transporte Público (1) OU (2) OU (3), segue-se para avaliação da próxima variável, "E" Acessibilidade ao Transporte Público que oferece três possibilidades (1) OU (2) OU (3) "E" Vias para Pedestres que oferece três possibilidades (1) OU (2) OU (3), até se chegar no último nível "E" Extensão e Conectividade de Ciclovias que também oferece três possibilidade (1) OU (2) OU (3), levando para quatro níveis de desempenho (I) OU (II) OU (III) OU (IV). Pela leitura do diagrama proposta na Figura 26, tem-se que ERTP (1), "E" ATP (1) “E” VP (1) “E” ECC (1), levam para um nível de desempenho "I" em relação aos elementos de transporte e circulação. Importa saber que existem outros caminhos que podem ser percorridas, todos dependerão da avaliação individual para cada variável proposta na árvore. 


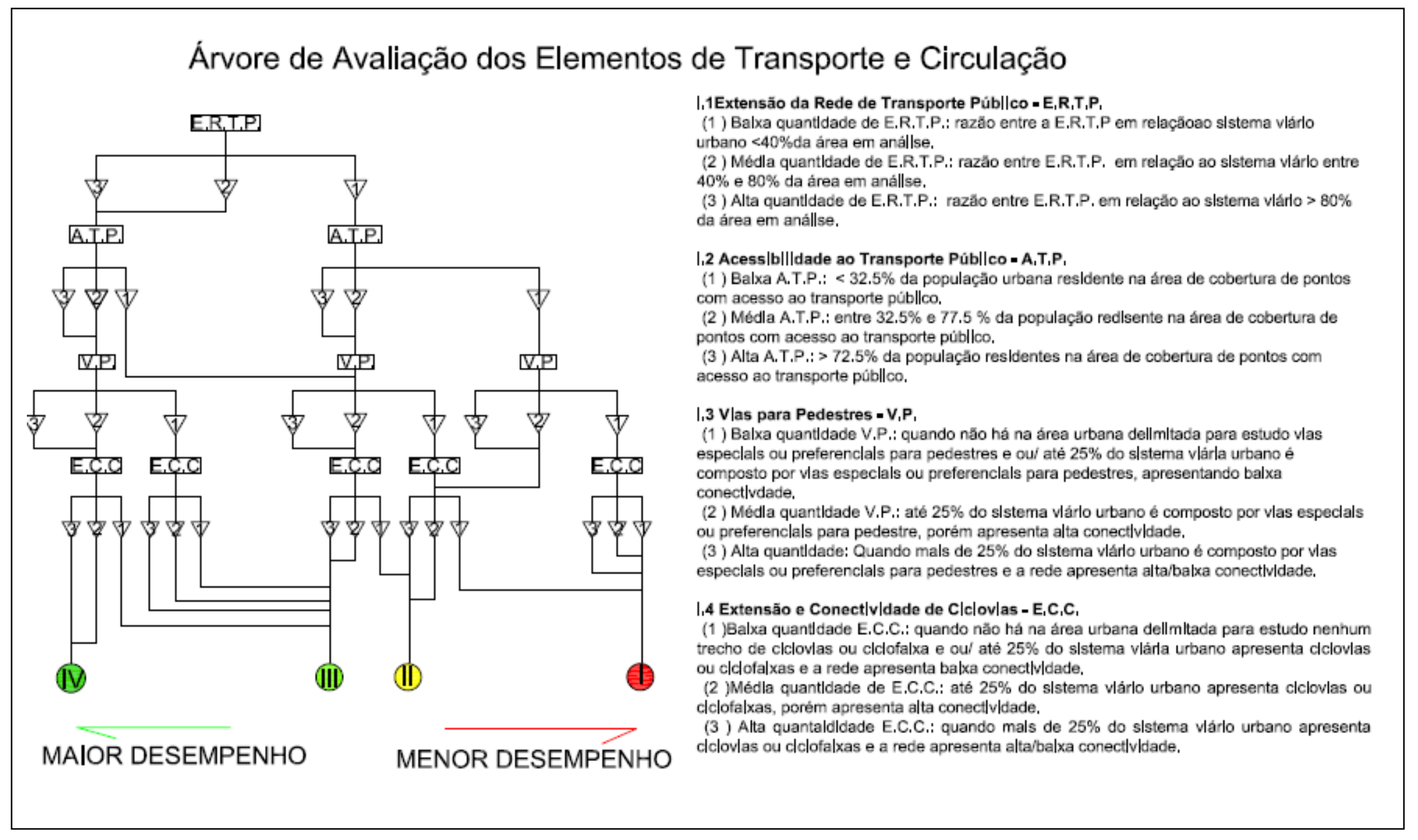

Figura 25: Eixo de Análise II - Elementos de Transporte e Circulação. 


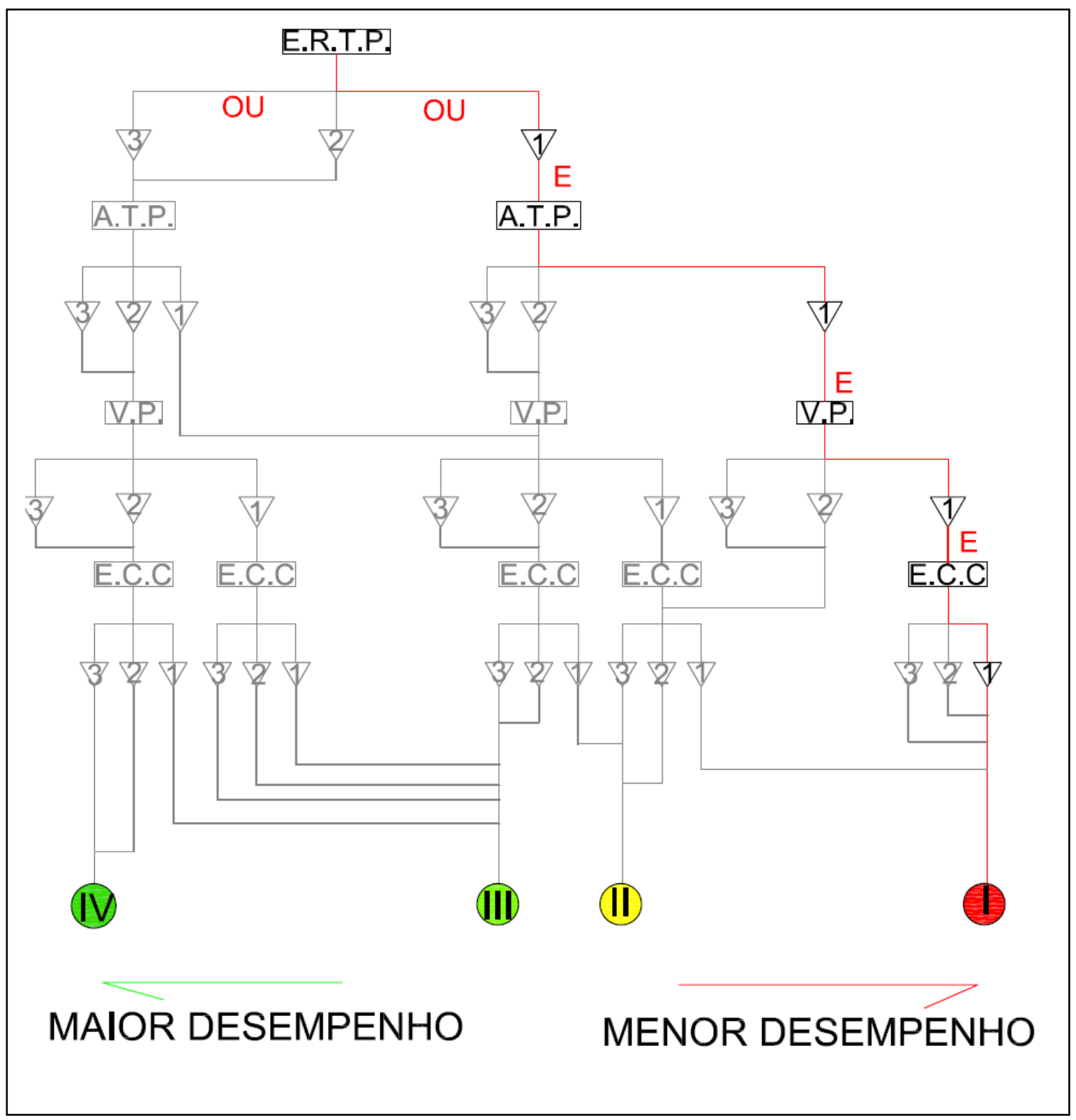

Figura 26: Exemplo de um dos caminhos percorridos na Árvore de Avaliação dos elementos de Transporte e Circulação e utilização da lógica matemática.

3.3.1.5 Combinação das árvores de avaliação: matriz potencial de mobilidade sustentável

Para combinar as árvores de avaliação dos Elementos da Forma Urbana e de Transporte e Circulação para espacialização dos resultados, é gerada uma matriz de agregação. Na elaboração da matriz cada nível da Forma Urbana é combinado, ou seja, relacionado aos níveis de Transporte e Circulação e vice-versa, gerando a matriz potencial de mobilidade sustentável ou Potencial de Mobilidade Sustentável.

As árvores e a matriz funcionam como filtros que selecionam alternativas até se chegar ao nível de maior potencial para mobilidade sustentável. A matriz é construída pela 
técnica de superposição de informações, levando em conta a maior prevalência das variáveis em área. A matriz potencial da mobilidade sustentável ficou definida conforme apresenta a Figura 27:
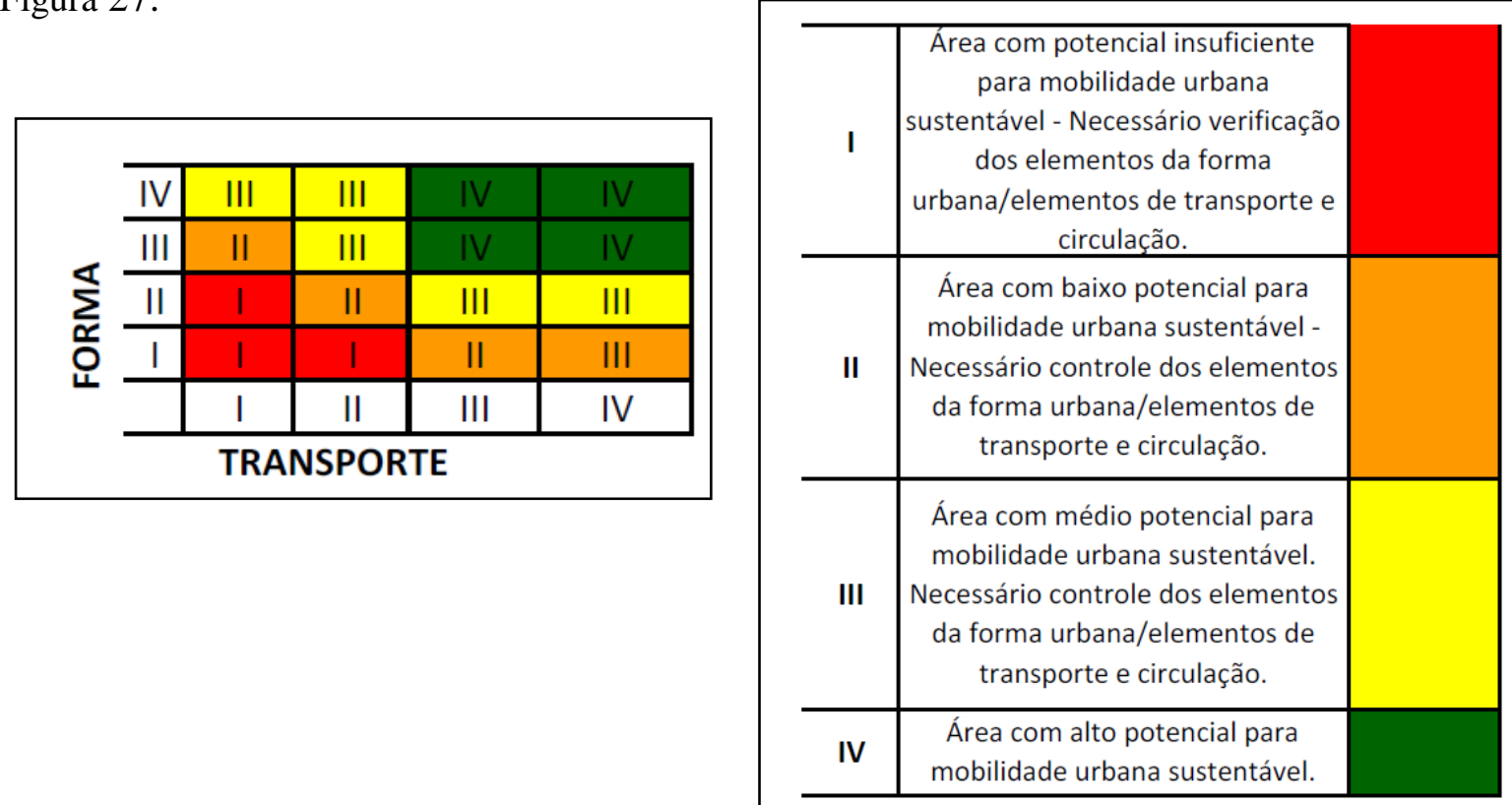

Figura 27: Matriz de Avaliação.

Por meio da matriz de agregação das variáveis, é possível espacializar os resultados e construir o mapa potencial da mobilidade sustentável. A escala de cores e níveis demonstrará as áreas com maior potencial para a mobilidade sustentável até as que apresentam desempenho insuficiente. A intervenção sobre desenho/planejamento urbano será dada nas áreas urbanas em que a correlação das variáveis expressar um pior desempenho. Portanto será possível criar níveis de análise em escala global e local para o planejamento, permitindo verificar as variações dentro de um mesmo sistema.

Para espacialização dos resultados, trabalha-se com os dados reais identificados pela atual situação da área. $\mathrm{Na}$ análise de cada micro-área dentro da área urbana, define-se o nível de potencial para mobilidade sustentável e as respectivas necessidades de intervenção sobre os elementos da Forma Urbana e do Transporte e Circulação.

Importa dizer que essa matriz pode ser alterada de acordo com o rigor que se deseja, restringindo ainda mais a análise para cada eixo de análise proposto.

\subsubsection{Proposição de medidas de controle}

A proposição de medidas de controle vai depender dos níveis estabelecidos na matriz. Para este estudo, foram propostos quatro níveis, conforme ilustra a Figura 27. Para cada nível, 
de acordo com os resultados apresentados, podem ser propostas soluções para melhorar o desempenho da mobilidade sustentável, seja em relação aos elementos que compõem a Forma Urbana ou os Elementos de Transporte e Circulação.

\subsection{Considerações finais do capítulo}

Neste capítulo, foram apresentadas as etapas que compõem o Procedimento de Análise Espacial, no qual se pretende relacionar Forma Urbana e Transporte para verificar o potencial de mobilidade sustentável em áreas urbanas. O Procedimento de Análise Espacial é uma ferramenta que permite estabelecer um potencial de mobilidade sustentável para determinada área urbana. É de fácil entendimento e aplicação, além de destacar as características da forma urbana como elementos indutores para potencializar a mobilidade sustentável.

As variáveis identificadas poderão ser adequadas às informações existentes; sendo assim, as árvores de avaliação poderão ser montadas conforme as informações disponíveis. $\mathrm{O}$ guia elaborado por Costa (2008), por apresentar parâmetros já testados quanto à mobilidade, serve de orientação quanto à alteração ou adequação de variáveis nos diagramas.

Algumas informações que não podem ser mapeadas ou especializadas constituem-se num limitante ao objetivo de se ter um Procedimento de Análise Espacial facilitador para o uso de planejadores urbanos; entretanto, essa limitação não reduz o mérito da proposta. No próximo capítulo será explorado o estudo de caso no município de Goiânia - GO, onde as possibilidades de aplicação do Procedimento de Análise Espacial são verificadas. 


\section{CAPÍTULO 4: ESTUDO DE CASO: ANÁLISE ESPACIAL DA MOBILIDADE NA CIDADE DE GOIÂNIA - GO.}

\section{INTRODUÇÃO}

Este capítulo apresenta o Procedimento de Análise Espacial aplicado à cidade de Goiânia, com objetivo de relacionar os aspectos da forma urbana aos de transporte e circulação, de modo a se verificar como as variáveis espaciais influenciam no potencial de mobilidade sustentável.

A escolha da cidade ocorreu em decorrência de vários fatores facilitadores do ponto de vista operacional, mas a ideia é que o Procedimento de Análise Espacial possa ser aplicado em qualquer estrutura urbana. Como aspectos que levaram à escolha de Goiânia, podem ser elencados: i. cidade planejada, construída em 1930, contemplando um processo diferenciado de desenho e conformação do espaço; ii. as características de população, área urbana e densidade revelaram uma menor dispersão em relação a outras cidades, conforme mostram pesquisa realizada por Ribeiro (2008), apresentada na Tabela 10 e Ojima $(2007)^{28}$. iii. existência de plano diretor (elaborado em 2007), com destaque para o tema da mobilidade e com diversas proposições que visam à sua promoção, o que se torna uma oportunidade de verificar sua efetividade; iv. em termos operacionais, a proximidade da Universidade de Brasília, local de desenvolvimento da pesquisa e do Instituto Federal de Goiás, local de trabalho da pesquisadora, tornou-se um facilitador na obtenção de dados.

\footnotetext{
${ }^{28}$ Ojima (2007), calculou o índice de dispersão para 37 cidades brasileiras, entre elas Goiânia, que aparece no ranking no posto 30 (Cf. Ojima, 2007) o que confirma a tendência de cidade mais compacta. Os dois autores utilizaram-se de métodos diferentes para cálculo do índice de dispersão; entretanto, foi possível verificar que, para Goiânia, as pesquisas revelam menor dispersão do território, sendo possível identificar um cenário próximo ao de cidade compacta, que corrobora para as premissas desta pesquisa;
} 
Tabela 10: Índice de dispersão 2000 e 2010.

\begin{tabular}{|c|c|c|c|c|c|}
\hline \multirow[b]{2}{*}{ Cidades } & \multicolumn{2}{|c|}{2000} & \multicolumn{2}{|c|}{2010} & \multirow[b]{2}{*}{$\begin{array}{l}\text { Região } \\
\text { Brasileira }\end{array}$} \\
\hline & $\begin{array}{c}\text { Índice } \\
\text { Dispersão }\end{array}$ & $\begin{array}{c}\text { Índice } \\
\text { Dispersão } \\
\text { Normalizado }\end{array}$ & $\begin{array}{c}\text { Índice } \\
\text { Dispersão }\end{array}$ & $\begin{array}{c}\text { Índice } \\
\text { Dispersão } \\
\text { Normalizado }\end{array}$ & \\
\hline RM São Paulo & 1,344 & 0,63 & 1,369 & 0,54 & Sudeste \\
\hline RM Curitiba & 1,578 & 0,47 & 1,487 & 0,44 & Sul \\
\hline RM Goiânia & 1,660 & 0,42 & 1,511 & 0,42 & Centro-oeste \\
\hline RM Fortaleza & 1,739 & 0,37 & 1,642 & 0,32 & Nordeste \\
\hline RM Belo Horizonte & 1,799 & 0,33 & 1,553 & 0,39 & Sudeste \\
\hline RM Recife & 1,932 & 0,24 & 2,026 & 0,02 & Nordeste \\
\hline RM Rio de Janeiro & 1,942 & 0,23 & 1,890 & 0,12 & Sudeste \\
\hline RM Florianópolis & 2,055 & 0,16 & 1,914 & 0,11 & Sul \\
\hline RM Vitória & 2,077 & 0,14 & 2,027 & 0,02 & Sudeste \\
\hline RM Salvador & 2,242 & 0,03 & 2,326 & $-0,22$ & Nordeste \\
\hline RM Campinas & 2,363 & $-0,05$ & 2,153 & $-0,08$ & Sudeste \\
\hline RM Porto Alegre & 2,43 & $-0,09$ & 2,038 & 0,01 & Sul \\
\hline RM Belém & 2,565 & $-0,18$ & 2,619 & $-0,45$ & Norte \\
\hline RM Natal & 2,593 & $-0,20$ & 2,085 & $-0,03$ & Nordeste \\
\hline RM Maringá & 2,681 & $-0,26$ & 2,964 & $-0,72$ & Sul \\
\hline $\begin{array}{l}\text { RM Distrito } \\
\text { Federal }\end{array}$ & 3,803 & $-1,00$ & 3,314 & $-1,00$ & Centro-oeste \\
\hline
\end{tabular}

Fonte: Ribeiro, 2008. Adaptado autor. Obs.: considerar para o índice de dispersão normalizado a seguinte escala de avaliação - entre 0,0 e 1,0 (cidades mais compactas) entre 0,0 e -1,0 (cidades mais dispersas).

\subsection{Contextualização geográfica da área objeto de estudo}

O município de Goiânia é a capital do Estado de Goiás e geograficamente, possui uma área de unidade territorial de 732,802 $\mathrm{Km}^{2}$, com uma população de $1.302 .001^{29}$ habitantes e densidade demográfica de 1776,14 hab/Km² (IBGE, 2010). As principais atividades econômicas são o comércio, serviços públicos, agropecuária e indústria. A Figura 28 ilustra a localização geográfica de Goiânia em relação ao Estado de Goiás e em relação ao Brasil.

\footnotetext{
${ }^{29}$ De acordo com a divulgação da estimativa populacional pelo IBGE, Goiânia alcançaria em 2014 o total populacional de 1.412 .364 .

Fonte: 


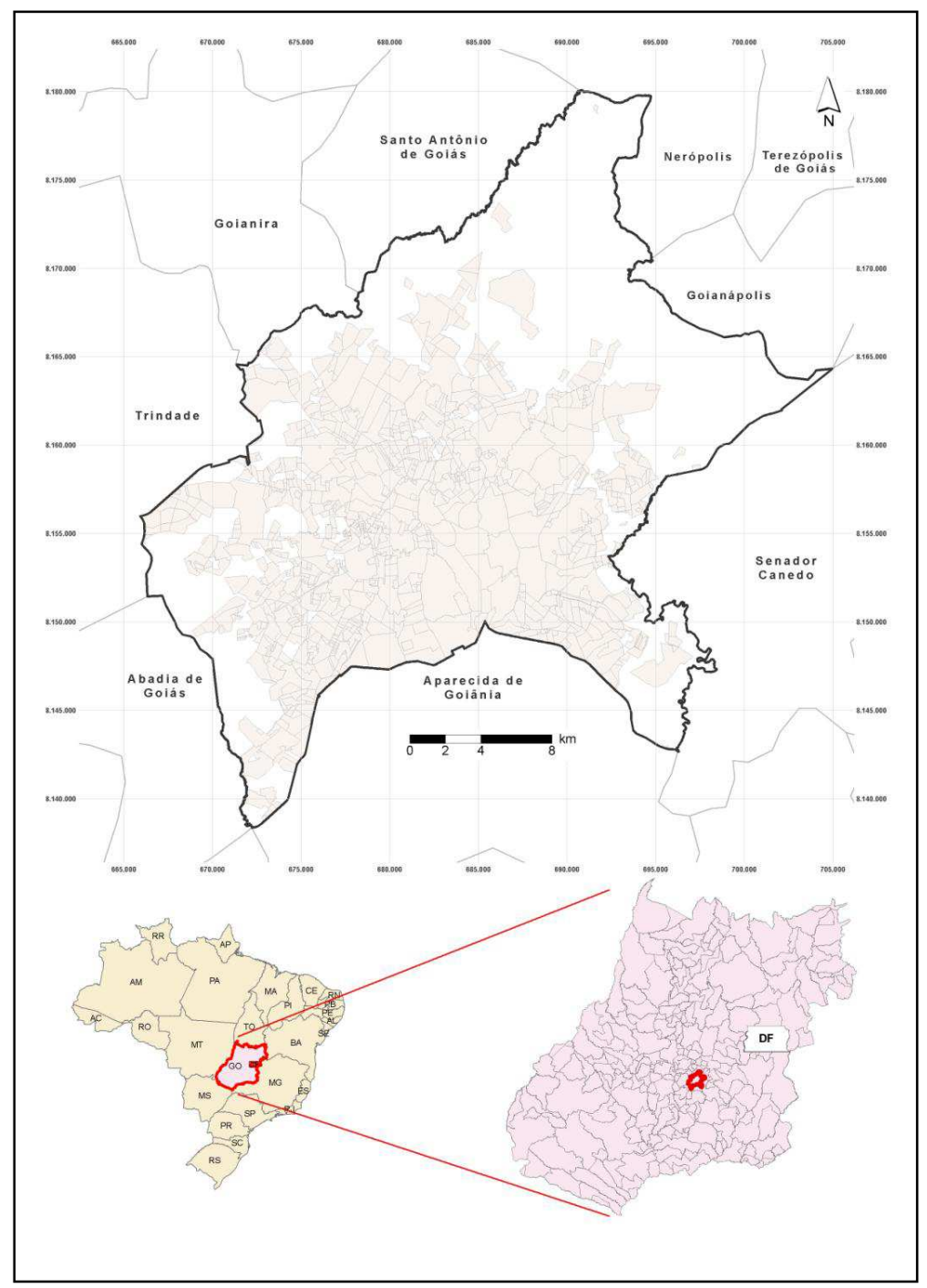

Figura 28: Localização de Goiânia - Goiás. Fonte: Abdala (2013).

A região metropolitana de Goiânia (RMG) foi criada pela Lei Complementar $n^{\circ} 027$, de 30 de dezembro de 1999, composta originalmente por 11 municípios que formavam a "Grande Goiânia" (Goiânia, Abadia de Goiás, Aparecida de Goiânia, Aragoiânia, Goianápolis, Hidrolândia, Nerópolis, Santo Antônio de Goiás, Senador Canedo e Trindade). Atualmente, por meio da Lei Complementar $n^{\circ}$ 078, de 25 de março de 2010, a RMG passou a ser composta por vinte municípios, conforme apresenta a Figura 29 (MÓYSES et al., 2011). A população total do conjunto de cidades que a formam é de 2.173 .141 habitantes, o que representa 36,19\% da população do Estado de Goiás (IBGE, 2010). 


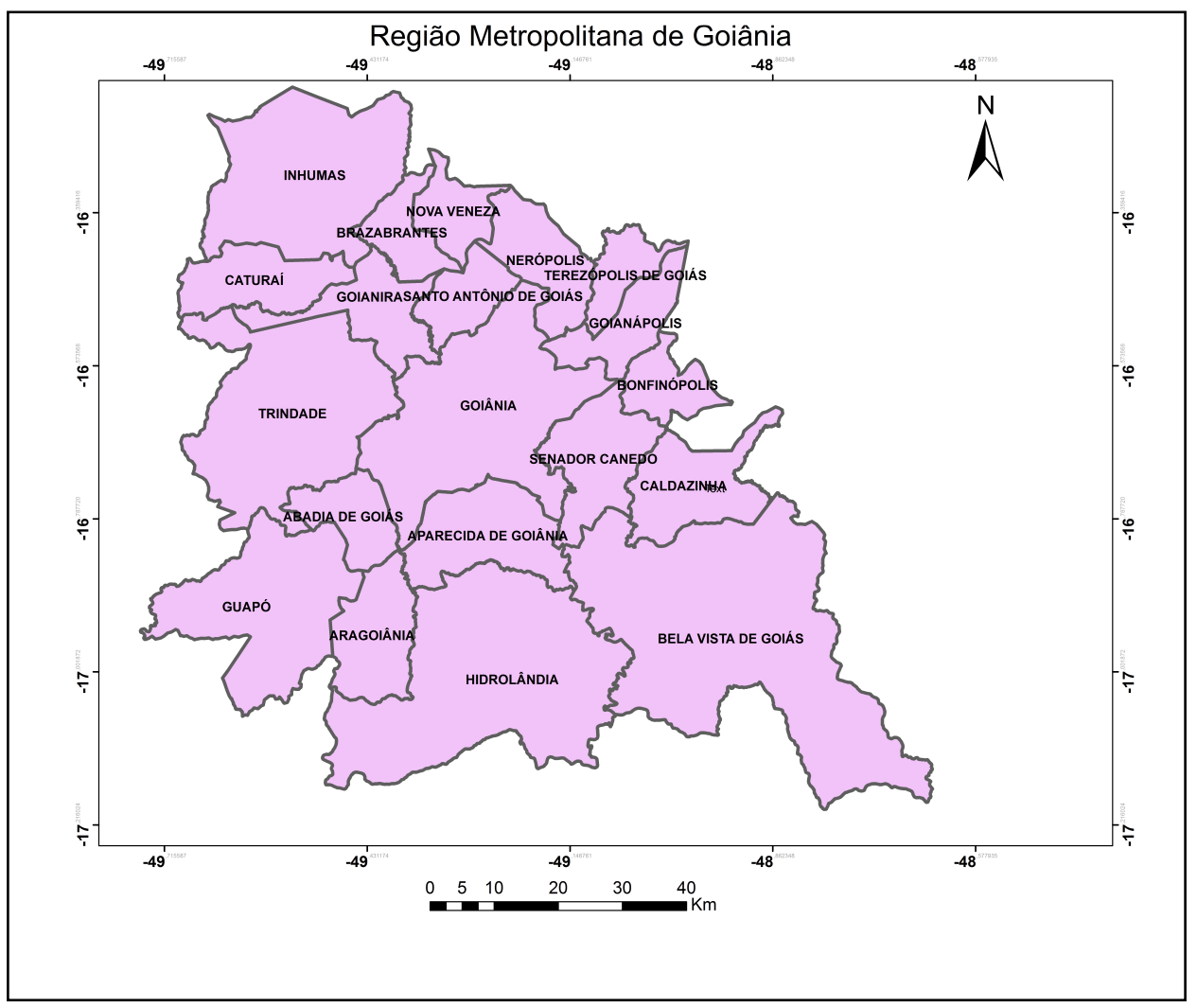

Figura 29: Região Metropolitana de Goiânia - RMG. Fonte: IBGE (2010), (adaptado).

De acordo com Viana e Arrais (2011), é difícil imaginar as relações entre os municípios da RMG sem considerar a mobilidade metropolitana, já que 18 dos 20 municípios se integram ao transporte coletivo por meio dos serviços prestados pela Companhia Metropolitana de Transportes Coletivos - CMTC. Porém, para esta pesquisa, em função dos dados obtidos, a área contemplada para estudo será apenas aquela correspondente ao município de Goiânia definida pelo IBGE (2010), conforme se verá adiante.

\subsection{Histórico urbanístico de Goiânia: Planejamento Urbano}

Goiânia foi construída para ser a capital político-administrativa do Estado de Goiás. De acordo com Oliveira (2004), a cidade surgiu a partir de uma demanda política e econômica que, no âmbito regional, buscava articular as regiões produtivas do Estado, principalmente o sul e o sudoeste. No âmbito nacional, a construção de Goiânia fazia parte de uma estratégia da "Marcha para Oeste", desenvolvida pelo governo de Getúlio Vargas com o objetivo de estimular o desenvolvimento da Região Centro-Oeste, incentivando sua ocupação.

A capital de Goiás, conforme coloca Moraes (2006), "traduz a simbologia do urbanismo moderno da década de 1930 e se orgulha do status de cidade planejada". Todavia, 
o domínio do Estado, no processo de criação da nova capital, favoreceu a formação de duas cidades distintas: a cidade planejada, onde se concentrou a população de maior poder aquisitivo e a cidade periférica, que abrigou as classes de menor poder aquisitivo. Os resultados desse tipo de planejamento urbano, em que os espaços urbanos são idealizados, planejados e construídos pelo poder público numa perspectiva global, parecem convergir para a institucionalização da segregação urbana, como ocorre também em Brasília e Palmas.

Vários autores propuseram uma divisão cronológica para o processo de urbanização de Goiânia. De modo geral, é possível identificar, por meio da literatura, três fases que a caracterizaram (MOYSÉS, 2004; MORAES, 1991):

(a) A primeira fase começa em 1933 e vai até 1950, sendo denominada "criação do lugar”. Nessa etapa, tem-se a consolidação do plano original concebido pelo arquiteto Atílio Corrêa Lima, que se fundamentou nos princípios do urbanismo clássico das primeiras décadas do século XX; o que seria o primeiro Plano de Urbanização de Goiânia. A cidade concebida para atender 50 mil habitantes e ficou caracterizada pela regularidade e classicismo de seu desenho urbano, zoneamento e sistema viário hierarquizado e radioconcêntrico (Figura 30 e Figura 31). Percebeu-se uma preocupação de Atílio em relação à configuração do terreno, considerando sua topografia, disposição das vias favorecendo o tráfego e a preservação de áreas verdes e matas ao redor de córregos. Segundo Gonçalves (2003), Atílio foi responsável pelos primeiros desenhos que se materializaram no setor central; entretanto, o arquiteto não permaneceu muito tempo à frente do projeto, o que foi continuado por Armando Godói. Na década de 1950, a cidade de Goiânia já contava com mais de 53 mil habitantes e, de acordo com Ferreira (2013), desse total, 75\% já residiam em perímetro urbano;

(b) A segunda fase ocorre entre 1951 a 1979 e foi denominada "ampliação do espaço" devido à liberação para parcelamento urbano por particulares. Goiânia expande-se para além dos limites previstos. Segundo Moysés (2004), "é o início do crescimento desordenado", em que o Estado perde o controle da expansão para a iniciativa privada. Ocorre durante o período um intenso processo migratório, de modo que o plano original é abandonado e o Estado, que esteve presente no período anterior, privatiza a construção da cidade. Para Moysés (2004), “constrói-se uma nova cidade que se sobrepõe a que existia". Essa etapa também se caracteriza pela tentativa de reorganizar o espaço urbano, com a contribuição do arquiteto paulista Luiz Saia, na década de 1950, e de Jorge Wilheim, responsável pela elaboração do primeiro Plano 
de Desenvolvimento Integrado de Goiânia, em 1968, que resultou na institucionalização do processo de planejamento em 1972;

(c) A terceira fase se dá a partir de 1979 e caracterizou-se pela preocupação com a expansão urbana de Goiânia, a partir dos fortes reflexos no seu entorno. O Estado, para resolver o problema do déficit habitacional, compra fazendas nos arredores da cidade e constrói conjuntos habitacionais de baixa qualidade, promovendo parcelamentos à revelia da legislação urbana vigente. O resultado é a segregação, na zona rural, a população pobre.

Após estas fases, Goiânia sofre uma série de transformações e implantação de planos diretores. Um novo ciclo de planejamento surgiu em 1993, com a elaboração do Plano de Desenvolvimento Integrado de Goiânia ou PDIG/2000. O mais recente plano urbanístico que a cidade dispõe resulta da Lei Complementar $n^{\circ} 171$, de 29 de maio de 2007 e adota o modelo de cidade compacta e preceitos do novo urbanismo em suas diretrizes gerais. $\mathrm{O}$ documento traz diretrizes importantes para potencializar a mobilidade sustentável, tema que será explorado no próximo item.

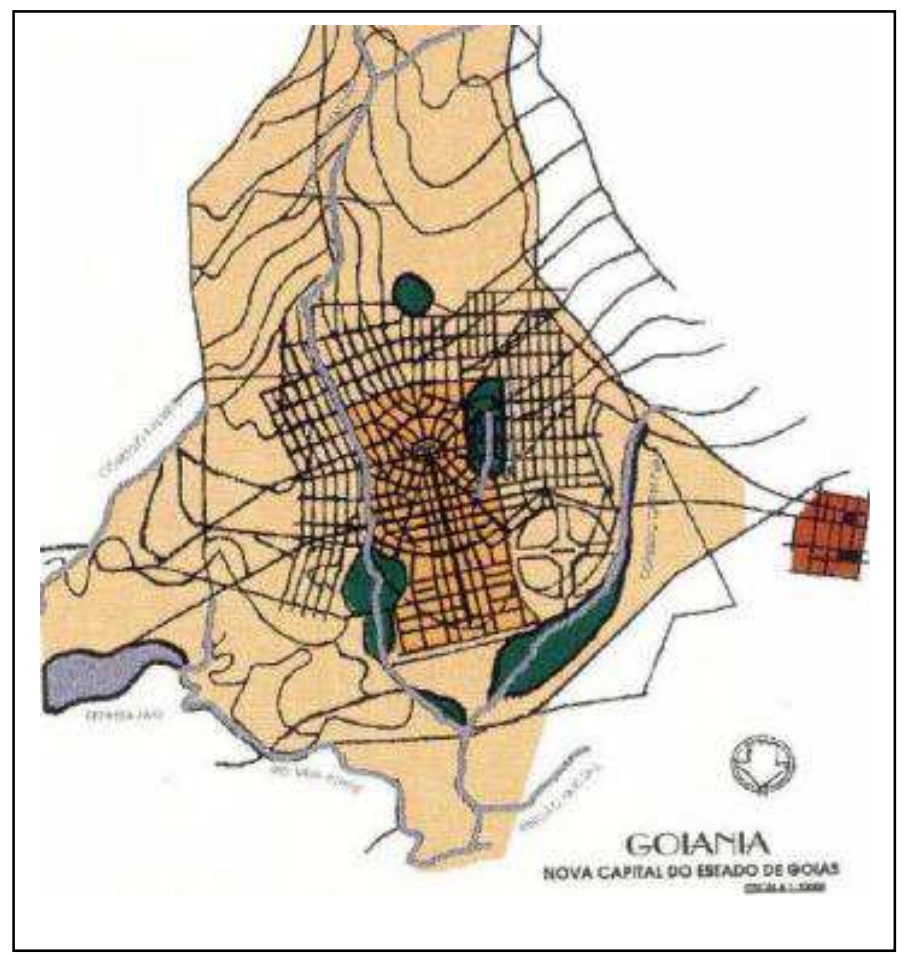

Figura 30: Plano original de Goiânia proposto por Atílio Corrêa 1933. Fonte: Bellorio, (2013). 

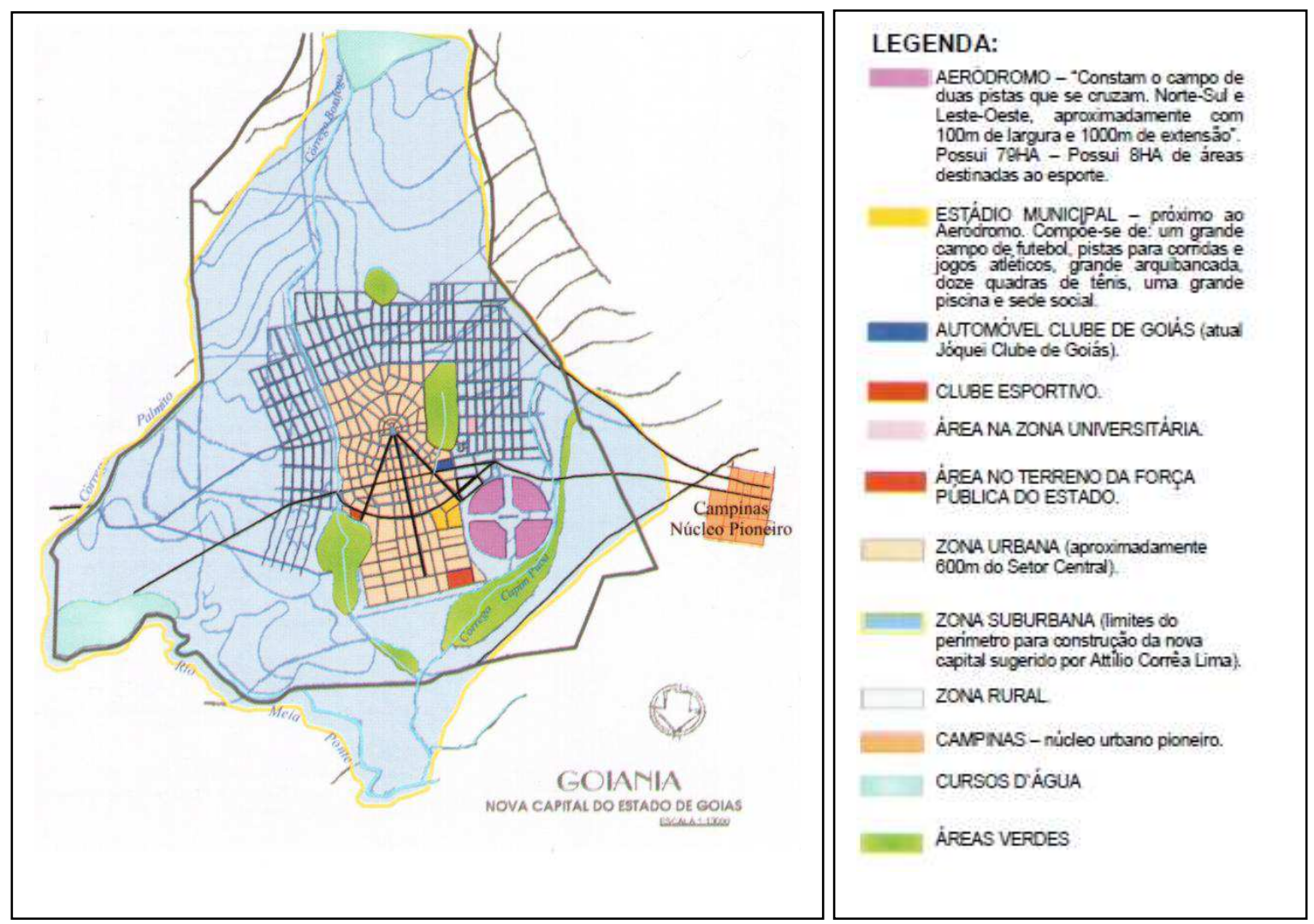

Figura 31: Zoneamento proposto por Atílio Corrêa para Goiânia, 1933. Fonte: Abdala, (2013).

\subsection{Goiânia: Plano Diretor e Mobilidade Urbana}

A mais recente legislação urbanística, o Plano Diretor de Goiânia - PDG (Lei Complementar $\mathrm{n}^{\circ} 171$, de 29 de maio de 2007), em síntese, explora os temas: modelo espacial, perímetro urbano, macrozoneamento da área urbana e rural, macro rede viária básica, sistema de transporte coletivo, desenvolvimento econômico, programas especiais e vazios urbanos. Tais tópicos foram estruturados em seis eixos estratégicos que versam sobre sustentabilidade socioambiental, ordenamento territorial, mobilidade/acessibilidade e transporte, desenvolvimento sociocultural, desenvolvimento econômico e gestão urbana.

De modo geral, entre os principais objetivos incorporados neste PDG (2007), têm-se premissas como a construção de uma cidade mais compacta; criação de corredores exclusivos de ônibus; promoção da geração de renda e emprego; promoção de uma política habitacional para estratos sociais mais baixos; implantação de programas especiais para revitalização; reurbanização e requalificação urbana; incentivo a projetos em áreas de interesse social e modernização administrativa. O município de Goiânia, de acordo com o PDG, ficou subdivido em duas macrozonas: construída e rural. Na porção rural, estão: Capivara, João Leite, São Domingos, Lageado, Alto Anicuns, Alto Dourados e Barreiros, conforme ilustra a Figura 32: 


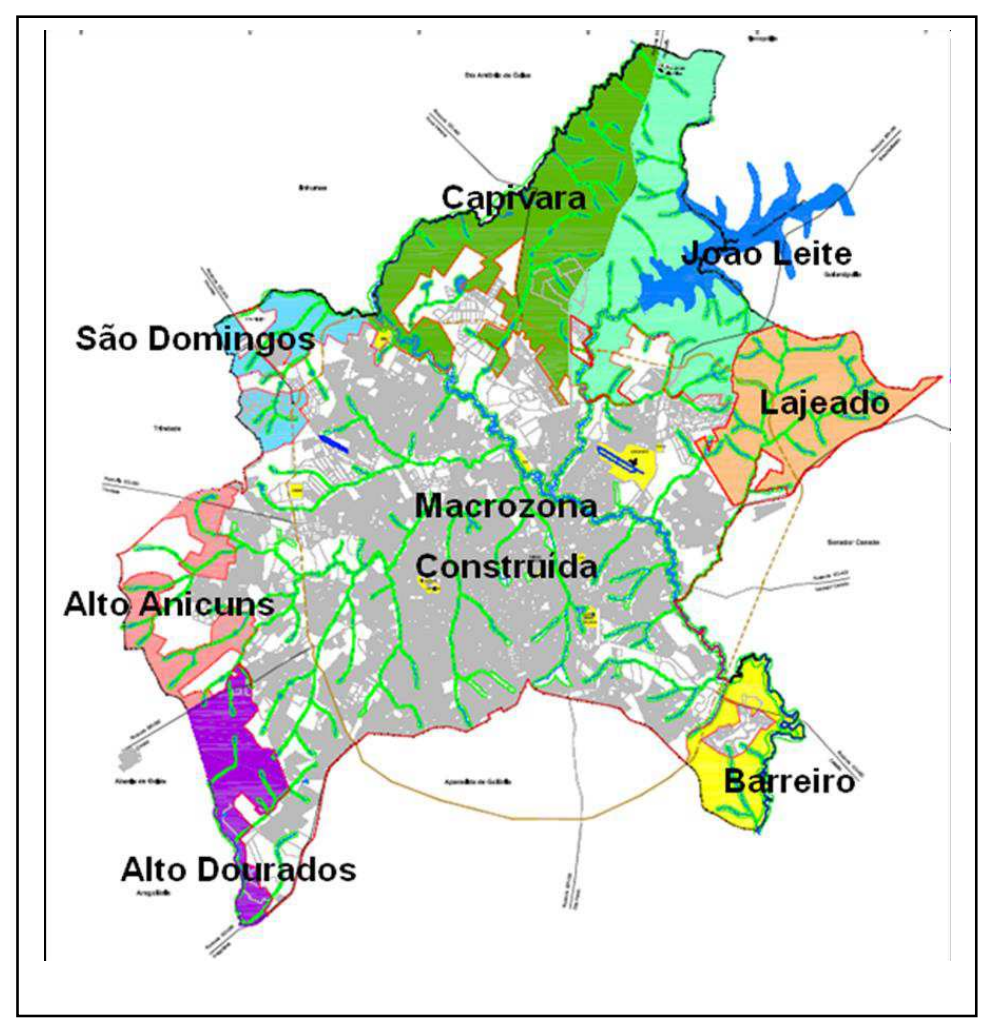

Figura 32: Macrozona construída e Macrozona rural. Fonte: Ferreira, 2013, Plano Diretor (2007).

Com relação à macrozona construída, o plano diretor apresenta um modelo espacial, no qual é possível verificar a subdivisão em seis áreas: i. áreas adensáveis: aqui são incentivadas maiores densidades habitacionais e de atividades econômicas, sustentadas pela rede viária e de transporte; ii. áreas de desaceleração das densidades: nessas áreas as ações são no sentido de desestimular o atual processo de densificação urbana; iii. áreas de adensamento básico: áreas de baixa densidade, para as quais será admitida a duplicação dos atuais padrões de densidade; iv. área especial de interesse social, para promoção da habitação social; v. áreas de uso sustentável: são aquelas contíguas às áreas de preservação permanente; e vi. áreas de restrição aeroportuária, referentes aos espaços adjacentes ao aeroporto de Goiânia (Figura 33). 


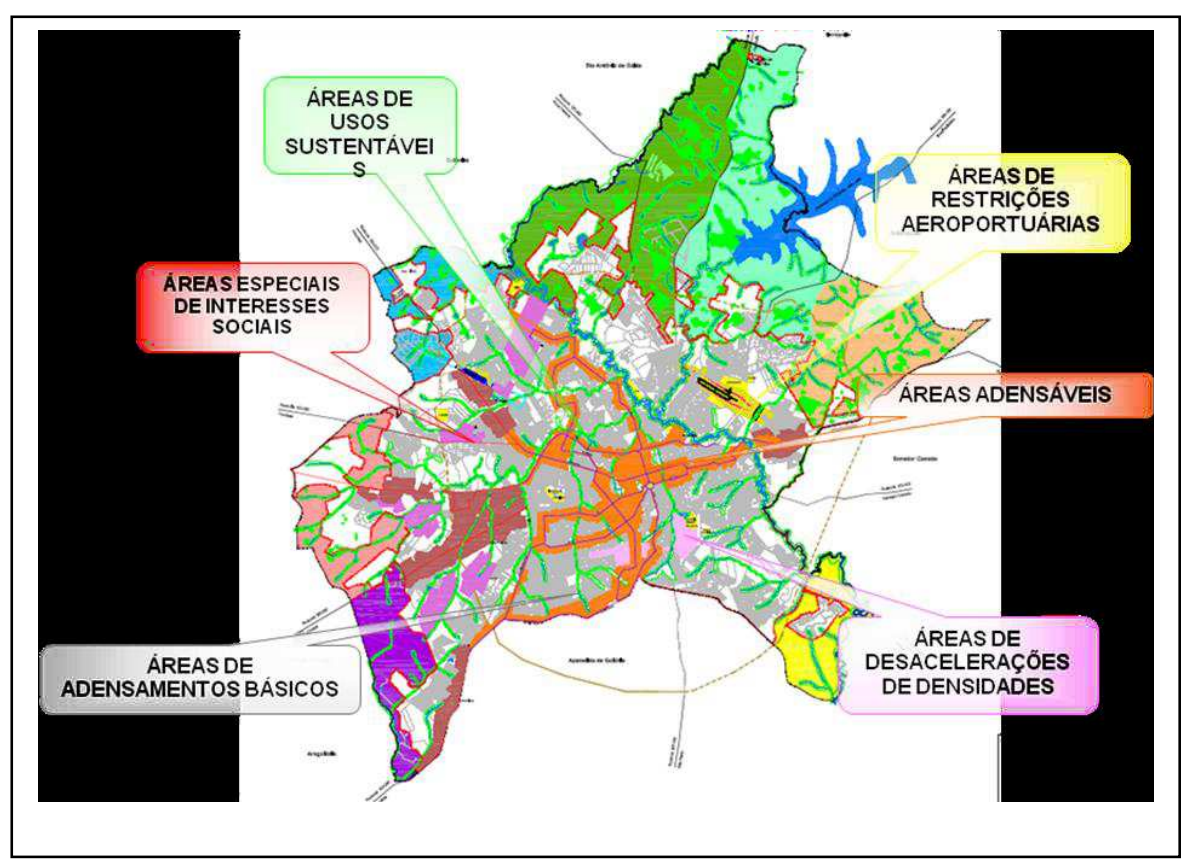

Figura 33: subdivisão macrozona construída. Fonte: Ferreira, (2013); Plano Diretor, (2007).

Em relação à abordagem relacionada à mobilidade urbana, Kneib (2012) destaca que:

[...] no plano da cidade de 1938 havia prioridade para as avenidas principais e abordagens sobre a largura das vias. No plano de 1964 priorizava-se o sistema viário. Nos planos de 1964 e 1992, chega-se a mencionar o transporte coletivo, mas a prioridade ainda são as vias. Apenas no último plano diretor, de 2007, é que se verificam abordagens sobre pedestres, ciclovias, acessibilidade, baseando-se em estratégias de adensamento em corredores de transporte com prioridade para os ônibus (Kneib, 2012).

Os fatores determinantes para o ordenamento territorial, a partir do Plano Diretor de 2007, recaíram sobre preceitos relevantes para a mobilidade, conforme cita Bellorio, (2013):

- Morfologia urbana: obtenção de uma cidade mais compacta e menos onerosa socialmente, evitando a dispersão do território;

- Mobilidade: implantação dos eixos estruturadores do transporte público como elemento estruturador de modelo de ocupação do território.

- Uso e ocupação do solo: compatibilização das atividades e da densidade com a capacidade da via. Estímulo à diversidade de uso do solo ou "uso misto" na cidade, promovendo a mescla de funções. É permitido o uso diversificado tanto de comércio como residencial, de acordo com o tipo de via e grau de incomodidade, 
proporcionando melhor aproveitamento da infraestrutura, resultando em menor necessidade de grandes deslocamentos.

O eixo estratégico de mobilidade, acessibilidade e transporte que consta no Plano incorpora os preceitos da sustentabilidade à capacidade de atendimento "às necessidades da sociedade de se deslocar livremente a fim de realizar as atividades desejadas, visando, em última análise, à melhoria da qualidade de vida urbana desta e das futuras gerações" (GOIÂNIA, 2007).

O Plano Diretor de 2007, além de tratar da prioridade do transporte público e dos nãomotorizados sobre o transporte individual, traz outros elementos que constituem medidas importantes para apoiar bons projetos de mobilidade e que estão vinculados às questões de uso do solo e rede viária. No documento, destacam-se as seguintes intenções: (i) planejar e adequar a rede viária para cumprir sua função estruturadora no tecido urbano, a incluir o redesenho das características geométricas da via, priorizando sua utilização pelo transporte coletivo, pedestre, ciclistas e acesso controlado às atividades econômicas lindeiras; (ii) compreender a rede viária como parte fundamental da estrutura urbana que deverá ser planejada, reorganizada, construída e mantida como suporte para circulação de pessoas, bens e mercadorias na cidade, de acordo com os princípios de mobilidade sustentável; (iii) garantir a implementação de uma rede viária compatível com as diretrizes de uso e ocupação do solo definidas na lei do plano diretor; (iv) propiciar a integração territorial do munícipio mediante a articulação viária e sua continuidade; (v) instituir os eixos de desenvolvimento urbano apoiados na rede estrutural do transporte coletivo, integrando uso do solo ao sistema de mobilidade urbana; (vi) definir áreas adensáveis para as quais devem ser incentivadas as maiores densidades habitacionais e de atividades econômicas, sustentadas pela rede viária e de transporte; (vii) estimular os meios não-motorizados de transporte, valorizando a bicicleta como um meio de transporte integrando-o com os modais de transporte coletivo; (viii) garantir na rede estrutural de transporte coletivo com corredores exclusivos, a capacidade de implantação de veículos articulados, bi-articulados, veículos leves sobre trilhos e modais com tecnologia metroviária.

Postos estes objetivos e propostas pelo Plano Diretor de Goiânia, é importante contar com procedimentos de análise que permitam de forma antecipatória, verificar se as medidas possuem, de fato, potencial de gerar os resultados almejados. Tratando-se de um plano já aprovado, o que se visa com a aplicação do Procedimento de Análise Espacial é identificar o alcance das medidas postas em curso e daquelas que, estando previstas, serão implantadas 
quando os diferentes agentes, públicos e privados, atuarem sobre o território em obediência ao plano diretor.

\subsection{Aplicação do Procedimento de Análise Espacial em Goiânia.}

4.4.1 Delimitação das áreas de análise

A delimitação da área de análise ${ }^{30}$ macro e micro, foi uma decisão que levou em conta, precipuamente, a disponibilidade de dados. Em função disto, ficou definida como macro área apenas o perímetro urbano de Goiânia, pois os dados disponíveis para pesquisa restringiam-se ao município sede da Região Metropolitana de Goiânia (RMG). A decisão de restringir as possibilidades de análise para a capital do Estado não inviabilizou o objetivo da pesquisa de tese, qual seja, testar o alcance do Procedimento de Análise Espacial para apoiar decisões de planejamento urbano.

A escala micro ficou definida como sendo as Regiões Administrativas ${ }^{31}$ (R.A.) da cidade, a saber: Centro-Campinas, Leste, Oeste, Sudoeste, Sul, Noroeste e Norte. A delimitação em unidades de análise menores possibilitou uma investigação mais detalhada, já que as árvores de avaliação são aplicadas para cada micro área. A Figura 34 ilustra área urbana dividida em sete regiões administrativas.

\footnotetext{
${ }^{30}$ Importa dizer que quanto menor a escala de análise, mais informações sobre o objeto de estudo se obtêm.

${ }^{31}$ A divisão administrativa considerada nessa pesquisa é a divisão mais recente (2010), adotada pela Prefeitura de Goiânia; contudo, até este momento (2015) ela não havia sido consolidada oficialmente.
} 


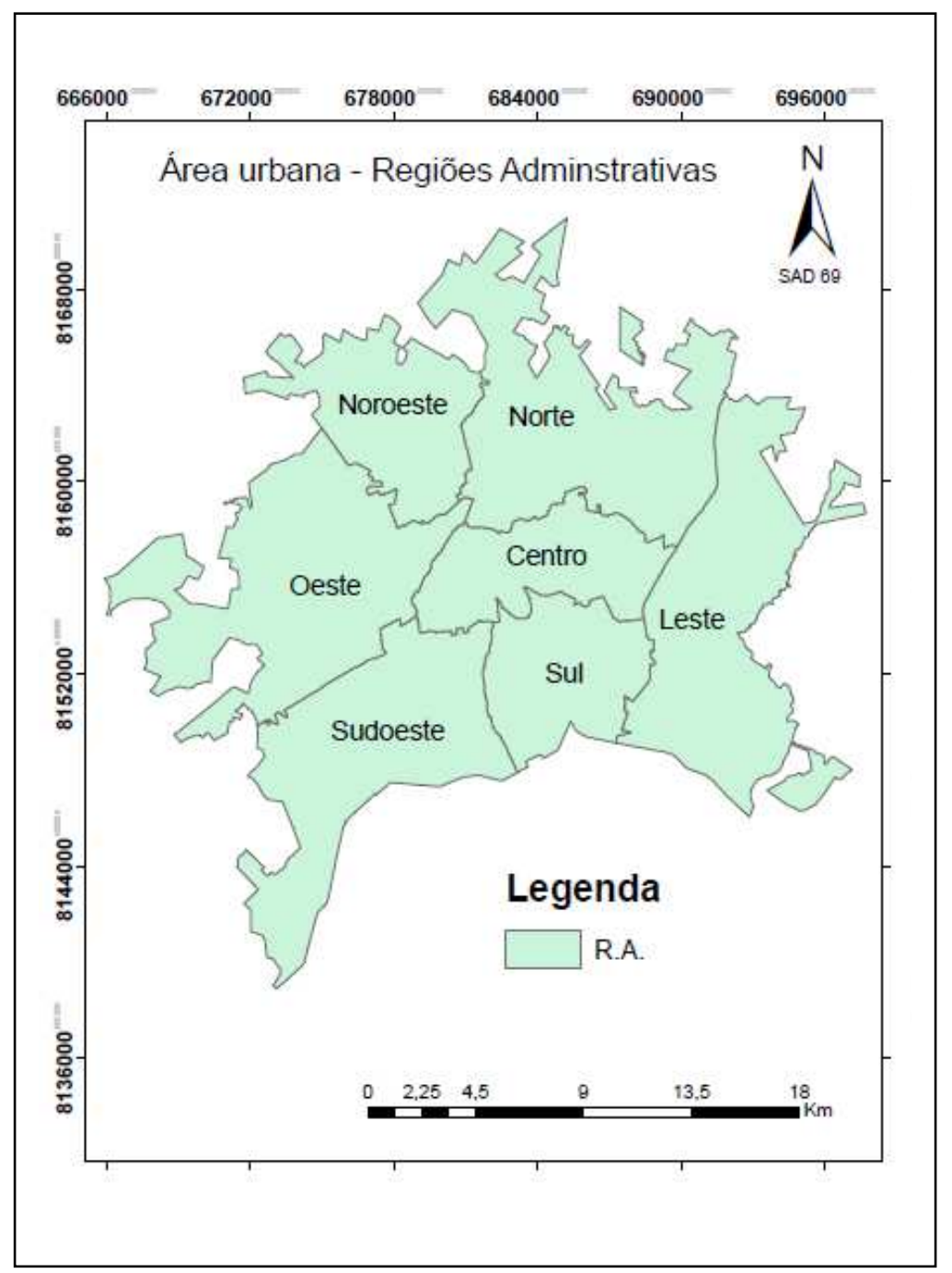

Figura 34: Perímetro urbano e as sete regiões administrativas. Elaboração: Autora

\subsubsection{Eixo de análise I: Decomposição do sistema "Forma Urbana"}

Para a perspectiva da "Forma Urbana", as seguintes varáveis foram analisadas:

i. características da densidade urbana;

ii. características do uso do solo urbano;

iii. continuidade;

iv. características do desenho urbano.

\section{i. Densidade Urbana}

A. Definição: Razão entre o número total de habitantes da região administrativa e a área total da região administrativa.

B. Fontes de Dados: Base georreferenciada do município, contendo as sete regiões administrativas, fornecida pela Secretaria de Tecnologia (SETEC, 2013); censo de habitantes 
para o ano de 2010 (IBGE, 2010); anuário estatístico fornecido pela Secretaria de Desenvolvimento Urbano e Sustentável de Goiânia (SEMDUS, 2013).

C. Método de Cálculo: Para o cálculo, foram verificados o número de total de habitantes em cada região administrativa e a área efetivamente urbanizada. O Quadro 12 apresenta a escala de avaliação para a variável Densidade Populacional enquanto a Tabela 11 demonstra os resultados para cada Região Administrativa (R.A.):

Quadro 12: Escala de avaliação para a variável densidade populacional em Goiânia.

\begin{tabular}{|c|l|}
\hline \multirow{2}{*}{ Avaliação } & \multicolumn{1}{|c|}{ Valores de Referência } \\
\cline { 2 - 2 } & Densidade populacional urbana \\
\hline $\mathbf{1}$ & Baixa densidade: $<$ de $50 \mathrm{hab} / \mathrm{ha}$ \\
\hline $\mathbf{2}$ & Alta densidade $:>$ de $50 \mathrm{hab} / \mathrm{ha}$ \\
\hline
\end{tabular}

Tabela 11: Resultado para a variável densidade populacional urbana em Goiânia.

\begin{tabular}{ccccc}
\hline $\begin{array}{c}\text { Região Administrativa } \\
\text { (RA) }\end{array}$ & População & $\begin{array}{c}\text { Área } \\
\text { (Ha) }\end{array}$ & $\begin{array}{c}\text { Densidade Urbana } \\
\text { (hab/ha) }\end{array}$ & Avaliação \\
\hline Centro - Campinas & 221.464 & 3451 & 64,17 & 2 \\
Leste & 172.436 & 4870 & 35,40 & 1 \\
Noroeste & 164.283 & 3342 & 49,15 & 1 \\
Norte & 146.677 & 4845 & 30,27 & 1 \\
Oeste & 152.189 & 5567 & 27,33 & 2 \\
Sudoeste & 223.027 & 3953 & 56,41 & 2 \\
Sul & 221.925 & 3542 & 62,65 & 2 \\
\hline
\end{tabular}

As Regiões Administrativas Centro, Sudoeste e Sul apresentam, dentro dos limites estabelecidos para avaliação da variável, as maiores densidades, enquanto que as regiões Leste, Noroeste, Norte e Oeste conformam menores densidades. Deve-se destacar que CentroCampinas e Sul atingiram as maiores densidades e são compostas por bairros mais populosos como o próprio Setor Central e Campinas, parte dos setores Bueno e Universitário. De acordo com o $\mathrm{PDG}^{32}$, tais regiões correspondem à “Área Adensável” (Figura 35), onde são estimuladas maiores densidades habitacionais e também atividades econômicas. Essas áreas também são mais servidas com rede de transporte, conforme se verá adiante a partir do

\footnotetext{
${ }^{32}$ Verificar Item 4.3, que descreve como devem ser as densidades em Goiânia de acordo com o último PDG, a partir da perspectiva da mobilidade urbana.
} 
cálculo da variável que determina a "Extensão da Rede de Transporte Público". A "Área de Desaceleração de Densidade" que contempla ações para controlar o atual processo de densificação urbana, corresponde aos bairros situados na região Sul: Alto da Glória, Jardim Goiás e Alto Bueno. As demais regiões foram estabelecidas como "Área de Adensamento Básico", em que são incentivadas maiores densidades, exceto em lugares próximos ao Aeroporto (definida no PDG como Área de Restrição Aeroportuária) ou quando há exigência de proteção ambiental. De modo geral, são incentivadas maiores densidades em toda área urbana de Goiânia; entretanto, é necessário estimular maiores densidades nas Regiões Administrativas que obtiveram desempenho pior em suas avaliações. A ampliação da densidade dentro do município de Goiânia, grosso modo, serviria para ocupar espaços vazios ou ociosos na cidade e evitaria ou amenizaria a continuidade do processo de espraiamento urbano.

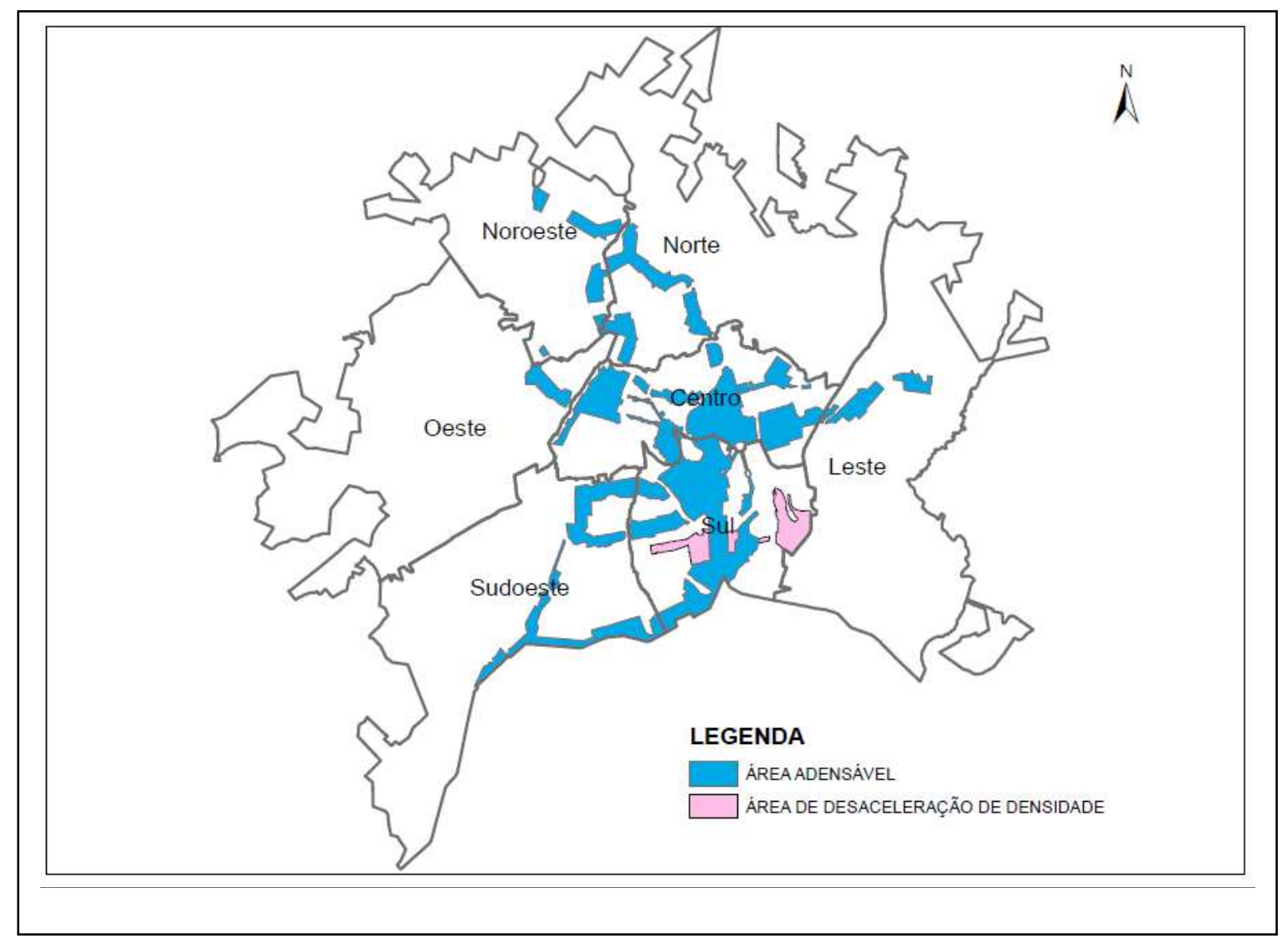

Figura 35: Cartograma de Goiânia ilustrando a “Área Adensável” e a "Área de Desaceleração de Densidade", de acordo com PDG (2007). 


\section{ii. Uso do Solo Urbano}

A. Definição: Porcentagem da área urbana destinada ao uso misto do solo, conforme definido em legislação municipal.

B. Fontes de Dados: Lei Municipal n ${ }^{\circ} 171$, de 29 de maio de 2007- Dispõe sobre o Plano Diretor e o processo de planejamento urbano do Município de Goiânia. Regulamentada por: Decreto $n^{\circ} 176$, de 23 de janeiro de 2008; Decreto $n^{\circ} 1.085$, de 05 de maio de 2008; Lei $n^{\circ}$ 8.645, de 23 de julho de 2008; Lei ${ }^{\circ}$ 8.646, de 23 de julho de 2008; Lei $n^{\circ} 8.760$, de 19 de janeiro de 2009; Lei ${ }^{\circ}$ 8.761, de 19 de janeiro de 2009; Lei $n^{\circ} 8.767$, de 19 de janeiro de 2009; Lei $\mathrm{n}^{\mathrm{o}}$ 8.834, de 22 de julho de 2009, (alterada pela Lei Complementar $\mathrm{n}^{\mathrm{o}} 181$, de 01 de outubro de 2008 e pela Lei Complementar $n^{\circ} 183$, de 19 de dezembro de 2008).

C. Método de Cálculo: O cálculo do indicador é realizado por meio da análise do Plano Diretor de Goiânia (PDG, 2007) a partir da identificação das zonas e setores onde é verificado o uso misto do solo, considerando os usos permitidos, tolerados e permissíveis. Identificou-se no PDG que o uso do solo acontece por meio do controle e da distribuição das atividades no território, que se dão de acordo com o grau de incomodidade e porte do uso consoante o porte da via em toda área urbana de Goiânia. Merecem destaque a Área Especial de Interesse Social e a Área de Uso Sustentável, em que são incentivados o uso misto: "Área Especial de Interesse Social (AEIS) - também nesta área há o uso misto, ou seja, acontece de acordo com o porte da via e o grau de incomodidade; Área de Uso Sustentável (AUS) - nesta área, a ocupação é menor e a área permeável exigida é maior do que nas demais áreas, porém o uso misto também acontece, de acordo com o porte da via e o grau de incomodidade; (PDG, 2007).

Como é permitido/incentivado o uso misto do solo com atividades compatíveis entre si e com uso residencial em todas as Regiões Administravas de Goiânia, considera-se, neste caso, alto potencial de uso misto. O Quadro 13 apresenta a escala de avaliação para a variável, e a Tabela 12 demonstra os resultados para cada região administrativa: 
Quadro 13: Escala de avaliação para a variável característica do uso do solo urbano.

\begin{tabular}{|c|c|}
\hline & Valores de Referência \\
\hline $\begin{array}{l}\text { Escala de } \\
\text { Avaliação }\end{array}$ & $\begin{array}{c}\text { Porcentagem da área urbana do município onde é } \\
\text { permitido/incentivado o uso misto do solo com } \\
\text { atividades compatíveis entre si e com o uso } \\
\text { residencial }\end{array}$ \\
\hline 1 & Baixo uso misto: $<50 \%$ da área em análise \\
\hline 2 & $\begin{array}{l}\text { Médio uso misto: entre } 50 \% \text { a } 75 \% \text { da área em } \\
\text { análise }\end{array}$ \\
\hline 3 & Alto uso misto: $>75 \%$ da área em análise \\
\hline
\end{tabular}

Tabela 12: Avaliação para o uso do solo urbano.

\begin{tabular}{cc}
\hline Região Administrativa & Avaliação \\
\hline Centro - Campinas & 3 \\
Leste & 3 \\
Noroeste & 3 \\
Norte & 3 \\
Oeste & 3 \\
Sudoeste & 3 \\
Sul & 3 \\
\hline
\end{tabular}

O uso do solo urbano em Goiânia, em função de sua legislação, traz homogeneidade em todas as regiões administrativas. Não foi possível obter dados numéricos que pudessem viabilizar a análise detalhada por R.A. Em conversa com especialistas da prefeitura de Goiânia, chegou-se à conclusão de que é incentivado o uso misto em toda área urbana, o que, a princípio, colabora para criar áreas com maior potencial de mobilidade sustentável. Sabe-se, entretanto, que as regiões Centro e Sul constituem as principais centralidades, conforme se verá no cálculo da variável de desenho urbano, de modo que as atividades de comércio, serviços, lazer, parques, dentre outras, são mais preponderantes nessas Regiões Administrativas, também são responsáveis pela maior parte dos deslocamentos.

O PDG traz elementos importantes em relação ao uso do solo urbano, pois considerou a possibilidade de incentivar todos os usos de acordo com o grau de incomodidade e também com o porte da via. Para elaboração do documento, criou-se um modelo espacial em Goiânia visando à integração entre o uso do solo e o sistema de mobilidade, por meio de eixos de 
desenvolvimento apoiados na rede estrutural de transporte público o que pode potencializar a mobilidade sustentável.

\section{iii. Vazios Urbanos}

A. Definição: Porcentagem de áreas que se encontram vazias ou desocupadas em cada região administrativa de Goiânia.

B. Fontes de Dados: Arquivo georreferenciado com os lotes vagos e área urbanizada, fornecido pelo Departamento de Geoprocessamento da Secretaria de Desenvolvimento Urbano Sustentável (SEMDUS, 2013).

C. Método de Cálculo: Por meio do arquivo georreferenciado, foram calculados os vazios e a área efetivamente urbanizada para cada R.A. O indicador foi obtido calculando a razão entre área total de vazios e área urbanizada expressa em \%. Os resultados seguem apresentados no Quadro 14 e na Tabela 13:

Quadro 14: Escala de avaliação para a variável "Vazios Urbanos".

\begin{tabular}{|c|l|}
\hline \multirow{2}{*}{ Score } & Valores de Referência \\
\cline { 2 - 2 } & $\begin{array}{l}\text { Porcentagem da área urbana do município vazia ou } \\
\text { desocupada em cada região administrativa de Goiânia }\end{array}$ \\
\hline $\mathbf{1}$ & Quantidade alta de vazios: > 50\% \\
\hline $\mathbf{2}$ & Quantidade média de vazios: valores entre $50 \%$ a $20 \%$ \\
\hline $\mathbf{3}$ & Quantidade baixa de vazios: $<20 \%$ \\
\hline
\end{tabular}

Tabela 13: Avaliação para a variável vazios urbanos em Goiânia.

\begin{tabular}{ccccc}
\hline R. A. & Área Urbanizada $\left(\mathbf{k m}^{2}\right)$ & Vazios $\left(\mathbf{K m}^{2}\right)$ & Vazios (\%) & Avaliação \\
\hline Centro-Campinas & 34,51 & 2,22 & $6 \%$ & 3 \\
Leste & 48,70 & 9,61 & $19 \%$ & 3 \\
Noroeste & 33,42 & 6,70 & $20 \%$ & 2 \\
Norte & 48,45 & 10,26 & $21 \%$ & 2 \\
Oeste & 55,67 & 11,64 & $21 \%$ & 2 \\
Sudoeste & 39,53 & 8,66 & $22 \%$ & 2 \\
Sul & 35,42 & 2,28 & $6 \%$ & 3 \\
\hline
\end{tabular}

De acordo com a escala de avaliação proposta, as Regiões Administrativas CentroCampinas, Leste e Sul apresentam baixa quantidade de vazios, variando entre $6 \%$ a $19 \%$ de vazios em relação à área efetivamente urbanizada. De acordo com os cálculos apresentados Centro-Campinas e Sul são as regiões com menor quantidade de vazios, seguido das regiões Leste e Noroeste com $19 \%$ e $20 \%$. Enquanto que as regiões Norte, Oeste e Sudoeste apresentam maiores quantidades de vazios, até $22 \%$. 
A região Sul sempre foi alvo da expansão urbana desde a criação da cidade (a partir da década de 1970). Atualmente se consolida como área nobre da cidade, constituindo uma centralidade importante, principalmente depois da criação do Bairro Jardim Goiás e uma variedade de equipamentos ali instalados como: hipermercados, shopping centers e a inauguração do Parque Flamboyant (2007), em função disso apresenta pouco vazios. A região Centro- Campinas sofreu ao longo do tempo uma descentralização populacional e econômica, entretanto o adensamento permaneceu nas áreas próximas, conduzindo a baixa quantidade de vazios nos bairros que compõem essa região.

A região sudoeste passou por um processo de expansão urbana nos últimos dez anos, com a criação de condomínios fechados (horizontais, verticais), construção do Conjunto Habitacional Madre Germana e também a proximidade com o município de Aparecida de Goiânia; é uma região que se consolida. A região Noroeste, é uma área que abriga pessoas com renda menor e que fica a uma distância maior em relação às áreas centrais, possui infraestrutura precária, mas também vem se consolidando. Segundo Moysés (2001), a região noroeste foi a que mais sofreu com movimento de luta pela terra, tendo diversos bairros constituídos por meio de invasões, sendo a primeira região a receber bairros populares como: Vila Mutirão I e II.

Os vazios urbanos, em se tratando da mobilidade, podem interferir nas distâncias a serem percorridas nas viagens cotidianas, aumentando os trajetos. Estão relacionados com a descontinuidade do tecido urbano, além da perda da qualidade ambiental. Em função disso, é importante ocupar os vazios nas áreas que demonstraram desempenho menor. 


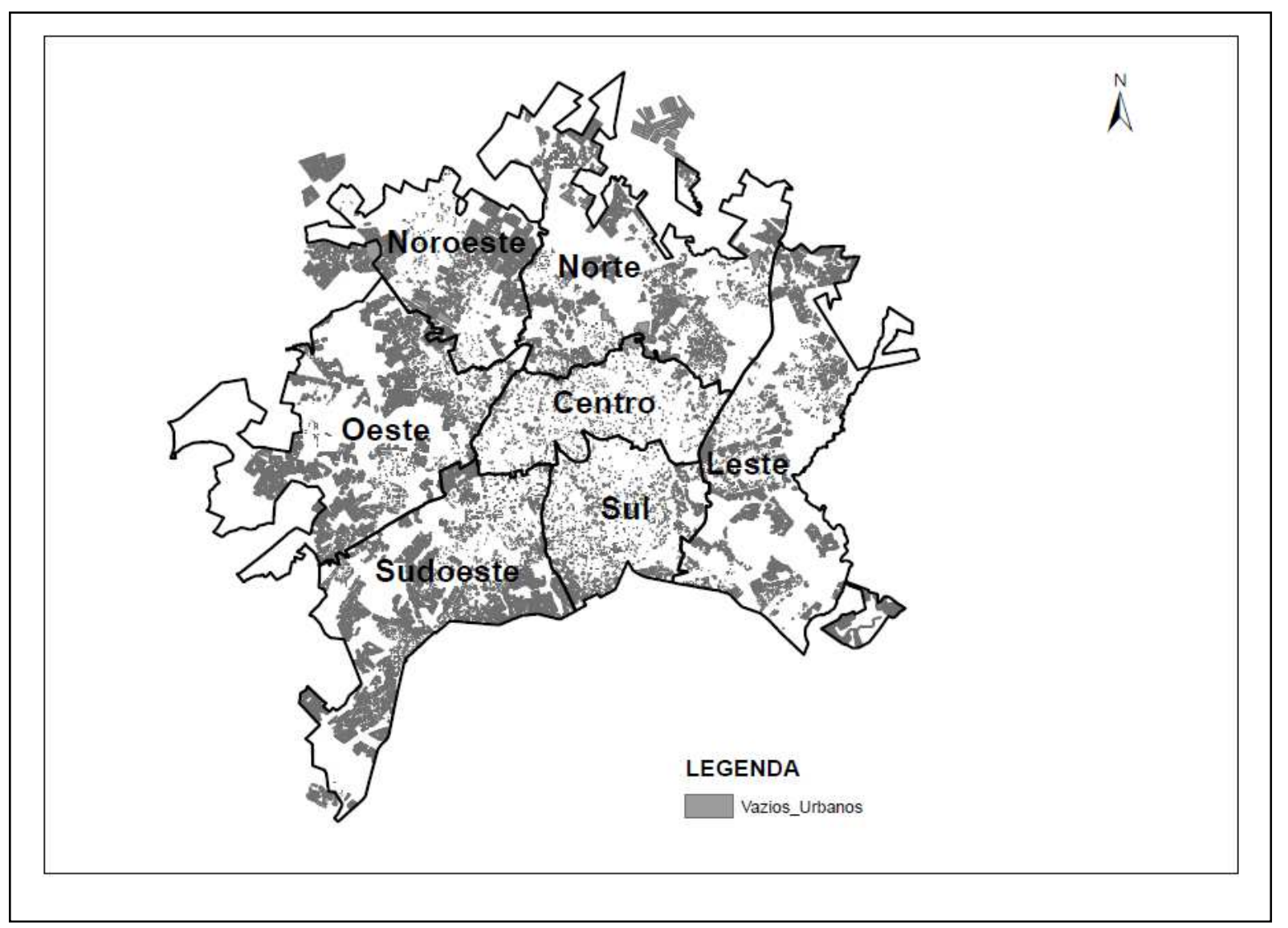

Figura 36: Distribuição dos Vazios Urbanos em Goiânia.

\section{iv. Características do Desenho Urbano - Integração Global}

A. Definição: Valor médio da variável integração global, obtido por meio da sintaxe espacial para cada região administrativa de Goiânia.

B. Fontes de Dados: Mapa axial de Goiânia, disponível em Medeiros (2013).

C. Método de Cálculo: O mapa axial foi exportado para ArcGis para fazer os recortes, de modo que fosse possível encontrar a média dos valores de integração para cada R.A. Foram geradas planilhas eletrônicas nas quais se obteve a média de integração global. O Quadro 15 apresenta escala de avaliação para o indicador desenho urbano. A Tabela 14 apresenta a avaliação para este indicador:

Quadro 15: Escala de avaliação para a variável desenho urbano - Integração Global.

\begin{tabular}{|l|l|}
\hline \multirow{2}{*}{ Score } & Valores de Referência \\
\cline { 2 - 2 } & $\begin{array}{l}\text { Média da variável integração global para cada região } \\
\text { administrativa de Goiânia }\end{array}$ \\
\hline 1 & Baixa integração: valor médio < 0,619 \\
\hline 2 & Média integração: valor médio entre 0,619 a 1,038 \\
\hline 3 & Alta integração $>1,038$ \\
\hline
\end{tabular}


Tabela 14: Avaliação para a variável desenho urbano - Integração Global para Goiânia.

\begin{tabular}{ccc}
\hline R. A. & Média & Avaliação \\
\hline Centro-Campinas & 0,7379 & 2 \\
Leste & 0,5376 & 1 \\
Noroeste & 0,5836 & 1 \\
Norte & 0,5609 & 1 \\
Oeste & 0,5905 & 1 \\
Sudoeste & 0,6223 & 2 \\
Sul & 0,7184 & 2 \\
\hline
\end{tabular}

A variável integração da Sintaxe Espacial refere-se ao nível de acessibilidade topológica de uma linha axial em relação às demais linhas no sistema e está relacionada ao tipo de desenho urbano, conforme descrito no capítulo anterior. Quanto aos níveis de integração, os resultados apontam para Centro - Campinas e Sul como as regiões com médias de valores de integração global mais altas, ou seja, nessas áreas estão as vias mais integradas e acessíveis, conforme ilustra Figura 37.

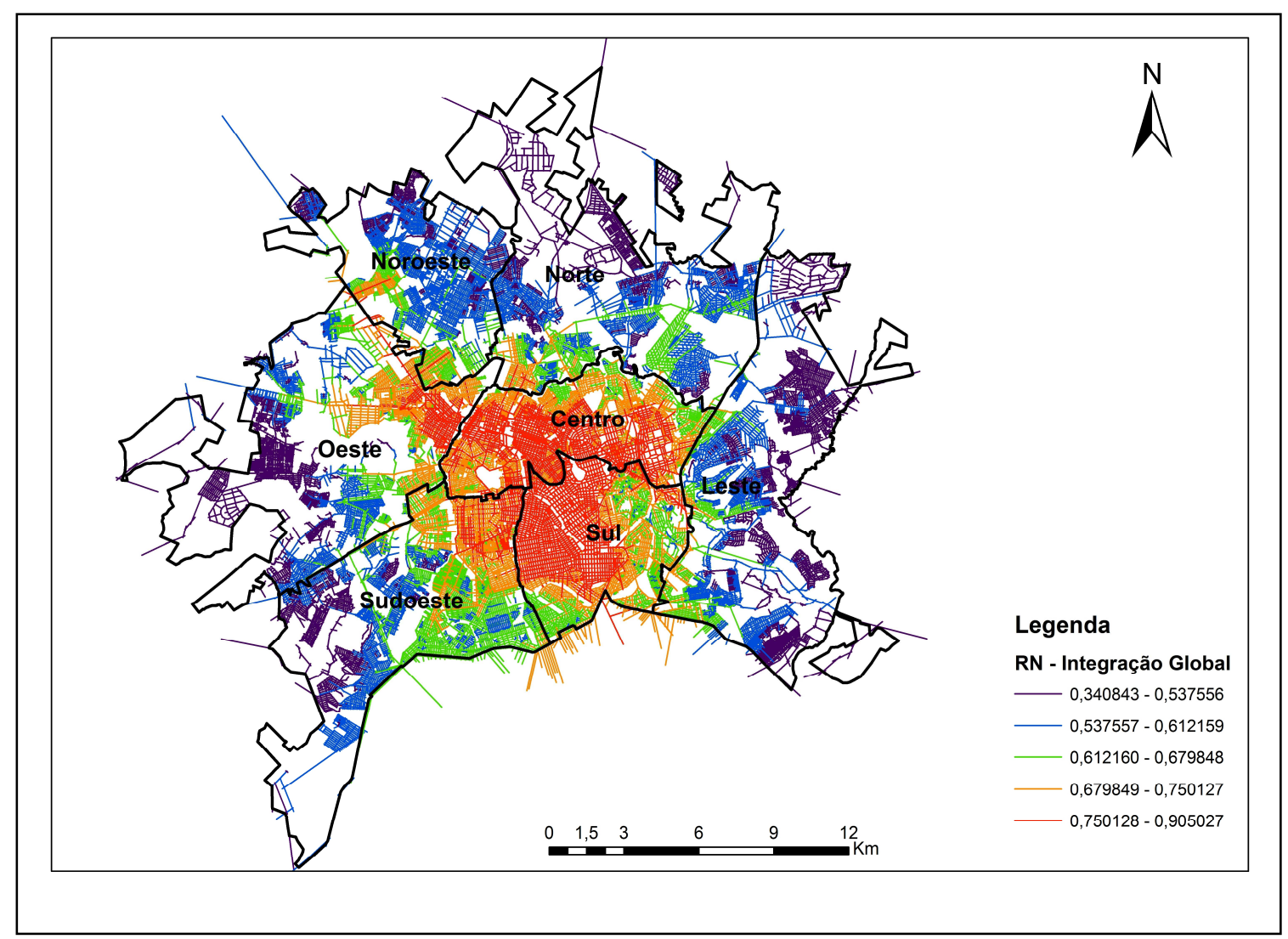

Figura 37: Espacialização dos resultados para variável Integração Global.

Ao confrontar esses resultados com as demais variáveis que compõem a árvore de avaliação forma urbana, verifica-se a coerência, tendo em conta que a Regiões 
Administrativas Centro-Campinas e Sul são as de maior aglomeração de pessoas, conforme indicado no cálculo da variável densidade urbana, alinhando-se ao estabelecido no Plano Diretor de Goiânia (PDG), ao coincidir com as áreas onde são propostos os adensamentos. Em relação ao uso, conforme já colocado, o PDG incentiva uso misto em todas as Regiões Administrativas. Todavia, as áreas, em que as atividades de comércio e serviços são mais intensas equivalem a Centro-Campinas e Sul, principalmente a primeira. Essas áreas correspondem às principais centralidades urbanas (Cf. Dias, 2014; Kneib, 2014) e são responsáveis por atrair muitas viagens, informações que conferem um grau positivo de correlacionamento entre as variáveis densidade e uso do solo urbano, em relação aos eixos considerados mais integrados pela SE na análise global. Apesar de não fazer parte deste estudo, apenas para complemento das análises, podem-se citar alguns trabalhos que indicam que, nessas áreas a renda da população é maior (Cf. Dias, 2014; Gentil et al., 2014; Kneib, 2014), o que aponta o entendimento da acessibilidade como um bem de forte valor de agregação. Os principais eixos de transporte público também coincidem com as áreas mais integradas.

Nas regiões Leste, Norte, Noroeste, Oeste e Sudoeste, os valores de integração são mais baixos. Aqui, também se verificam densidades menores, maior quantidade de vazios e são regiões consideradas menos acessíveis, tendo em vista que a população tem a necessidade de atravessar longas distâncias para alcançá-las, gastando mais tempo a fim de acessar o sistema de transporte mais fortemente articulado da cidade. Neste caso, também se observa que a população é de renda mais baixa e a infraestrutura de transporte é mais precária.

Ao analisar o desenho urbano, por meio da variável integração global, nota-se que a área central e suas adjacências, por serem fruto de um desenho urbano planejado e radioconcêntrico, permitiram criar um cenário com maior potencial de acessibilidade topológica. Entretanto, o desenho das vias nos demais setores mostra-se fragmentado, desarticulado da malha principal, colaborando por criar áreas com índices de integração menores e pouco acessíveis.

Outras análises procedidas em relação ao desenho urbano, no que diz respeito à integração global, consideram a importância de se criar uma malha articulada e acessível. Dessa forma, ações desenvolvidas poderiam prover todas as Regiões Administrativas de centralidades locais, isto é, subcentros, característica importante para potencializar a mobilidade sustentável. 
4.4.3 Agregação das variáveis do Eixo de Análise I - Árvore de Avaliação: Mapa Síntese Forma Urbana

A agregação das variáveis deste eixo será feita por meio da Árvore de Avaliação apresentada na Figura 38:

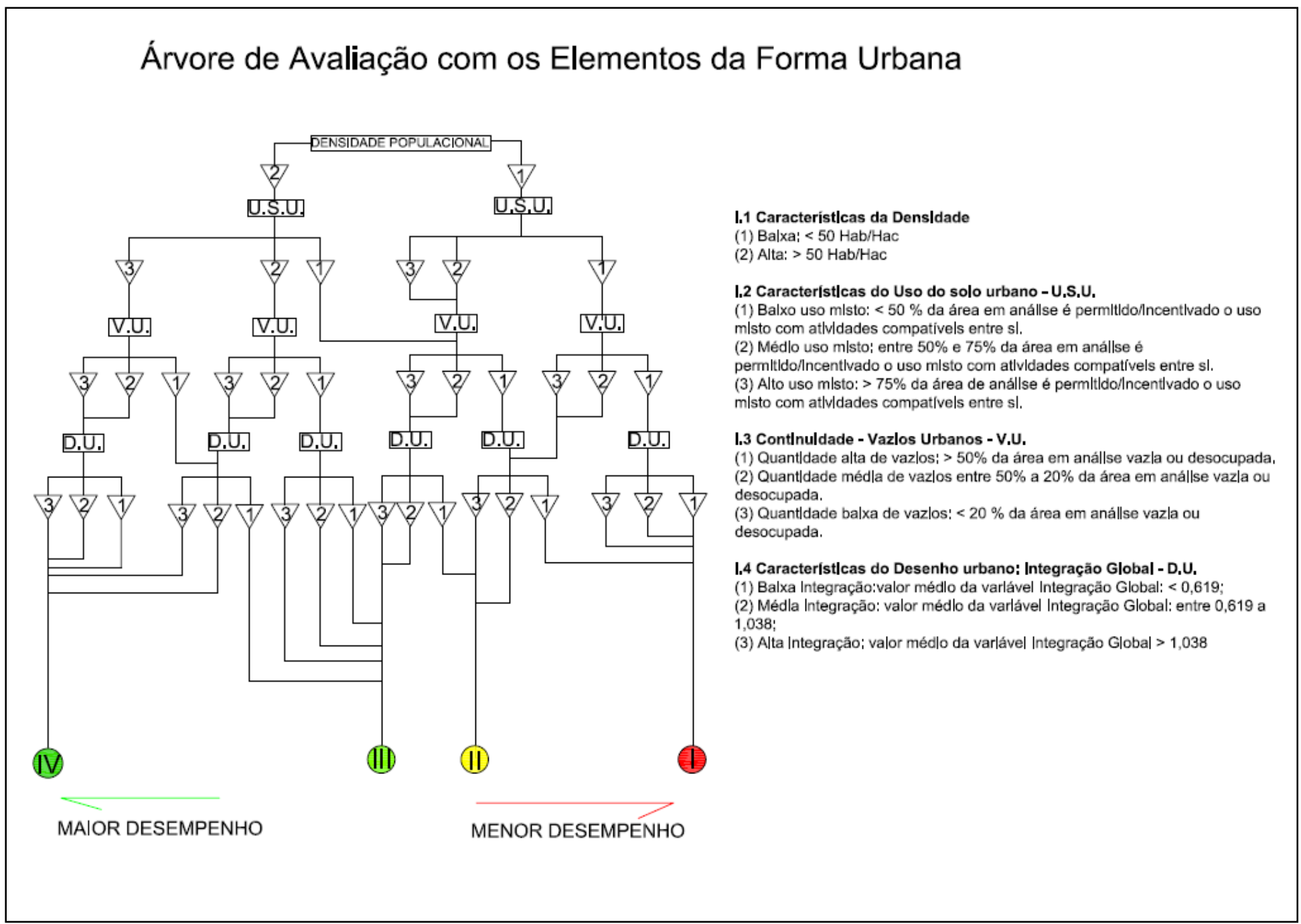

Figura 38: Árvore de avaliação para agregação das variáveis dispostas no Eixo de Análise "Forma Urbana". Elaboração: Autora (2014). 
De acordo com os resultados obtidos para cada variável (Tabela 15) e utilizando-se da Árvore de Avaliação proposta para Forma Urbana ilustrada na Figura 38, foi possível espacializar e combinar cada variável em ordem hierárquica. A Figura 40 ilustra o resultado das combinações no "Mapa Síntese da Forma Urbana" para todas as Regiões Administrativas.

Tabela 15 : Resumo da avaliação das variáveis para cada R.A em Goiânia.

\begin{tabular}{lccccc}
\hline $\begin{array}{l}\text { Indicadores } \\
\text { RA }\end{array}$ & $\begin{array}{c}\text { Densidade } \\
\text { Populacional }\end{array}$ & $\begin{array}{c}\text { Uso do solo } \\
\text { Urbano }\end{array}$ & $\begin{array}{c}\text { Vazios } \\
\text { Urbanos }\end{array}$ & $\begin{array}{c}\text { Desenho } \\
\text { Urbano }\end{array}$ & $\begin{array}{c}\text { Avaliação } \\
\text { Forma } \\
\text { Urbana }\end{array}$ \\
\hline Centro & 2 & 3 & 3 & 2 & IV \\
Campinas & 1 & 3 & 3 & 1 & II \\
Leste & 1 & 3 & 2 & 1 & II \\
Noroeste & 1 & 3 & 2 & 1 & II \\
Norte & 1 & 3 & 2 & 1 & II \\
Oeste & 2 & 3 & 2 & 2 & IV \\
Sudoeste & 2 & 3 & 3 & 2 & IV \\
\hline Sul & 2 & & & & \\
\hline
\end{tabular}

A Figura 39 ilustra o caminho percorrido na Árvore de Avaliação Forma Urbana para Região Administrativa Centro-Campinas, assim a análise foi feita para as demais áreas.

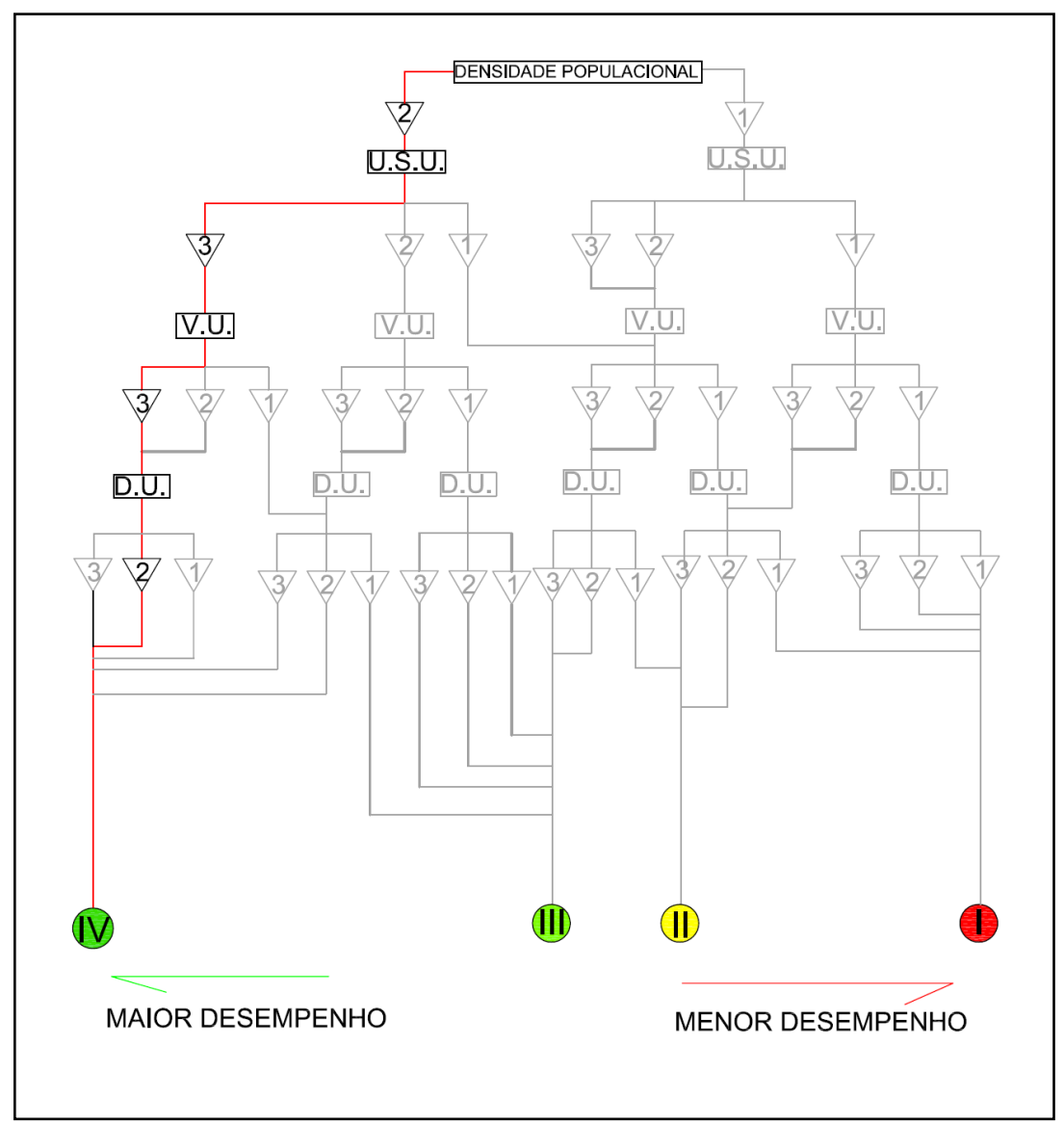

Figura 39: Caminho percorrido na árvore de avaliação para R.A. Centro - Campinas. 
A espacialização dos resultados demonstra que, em Goiânia, as regiões Centro, Sul e Sudoeste reúnem características da Forma Urbana que podem intensificar o processo de mobilidade sustentável. Nessas Regiões Administrativas as densidades são maiores, há incentivo do uso misto e os vazios existem em pouca ou média quantidade. O desenho urbano apresenta linhas de alta integração, que pode influenciar no estabelecimento de novos eixos de transporte público, o que demonstra também maior acessibilidade em relação a todo sistema viário analisado. A combinação dessas características leva na Árvore de Avaliação, para o campo de alto potencial em relação aos atributos da Forma Urbana.

As regiões Leste, Noroeste, Norte e Oeste apresentam desempenho regular em relação à variável uso do solo e vazios. Já densidade urbana e desenho urbano obtiveram pior avaliação. Essa combinação leva para uma área com baixo desempenho em relação aos atributos da forma urbana, merecendo destaque os indicadores que apresentaram desempenhos menores. As análises em relação a esse resultado serão retomadas nos itens 4.4.2.5 e 4.4.3. 


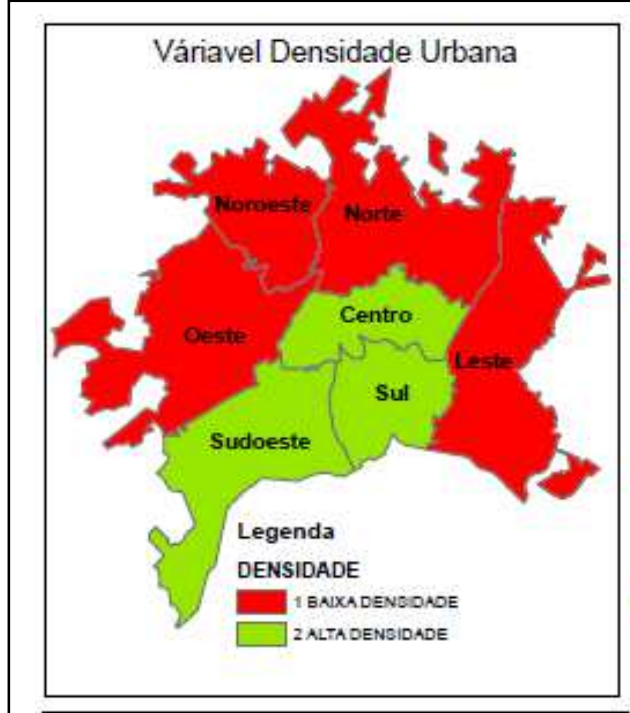

Variável Uso do Solo Urbano
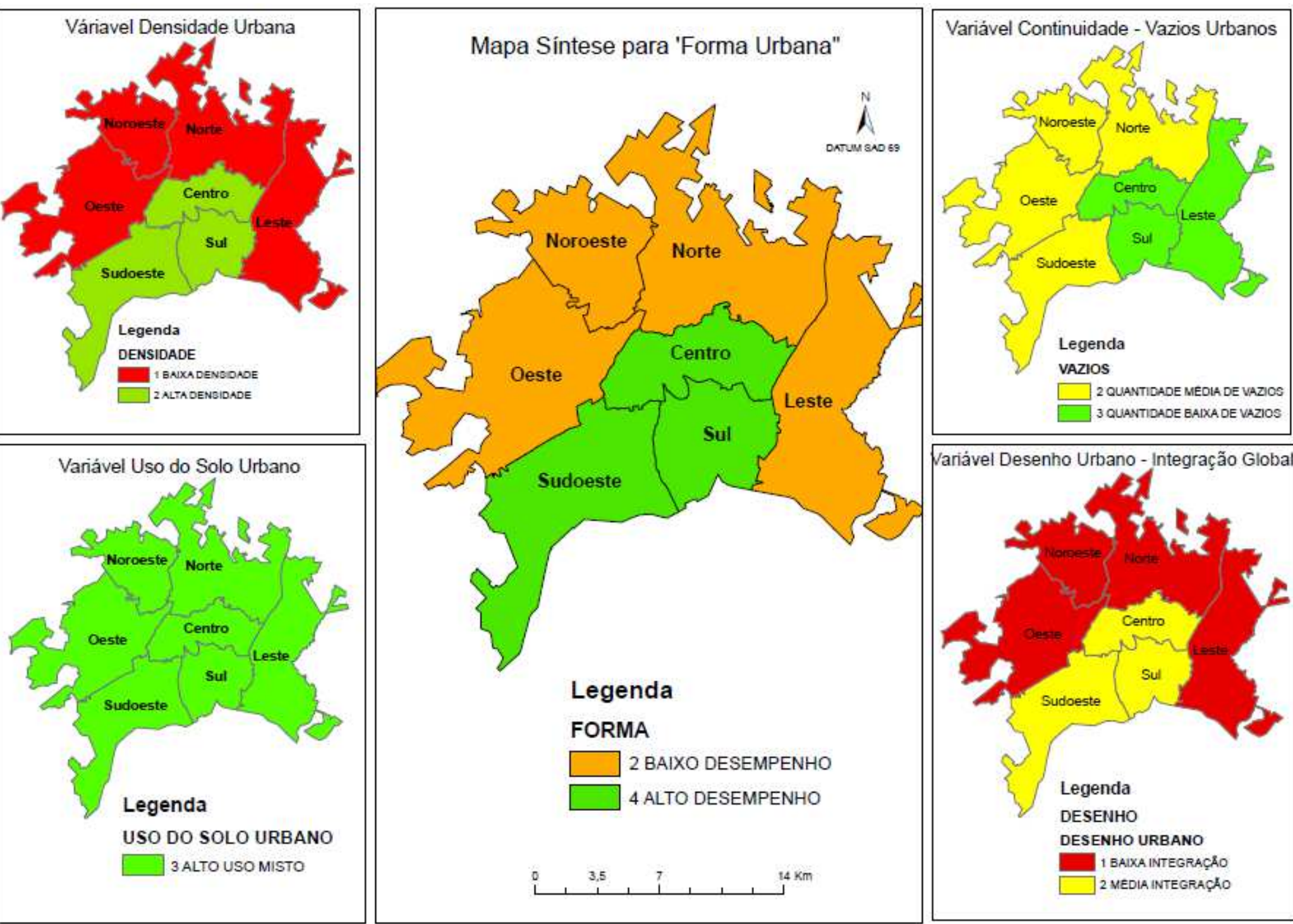

Figura 40 : Mapa síntese da Forma Urbana. Espacialização dos resultados para todas as variáveis do Eixo de Análise I. Elaboração: Autora (2014) 
4.4.4 Eixo de análise II: Decomposição do sistema "Transporte e Circulação"

Para o eixo de análise II, associado à perspectiva de "Transporte e Circulação" as seguintes variáveis foram analisadas:

i. extensão da rede de transporte público;

ii. acessibilidade ao transporte público (cobertura do transporte público);

iii. extensão de vias para pedestres;

iv. extensão e conectividade de ciclovias.

\section{i. Extensão da Rede de Transporte Público (E.R.T.P.)}

A. Definição: Extensão total da rede de transporte público em relação à extensão total do sistema viário urbano para cada Região Administrativa de Goiânia.

B. Fontes de Dados: Linhas de ônibus obtidas na CMTC e sistema viário municipal oriundo da base cartográfica disponibilizada pelo setor de geoprocessamento da Secretaria de Desenvolvimento Urbano e Sustentável de Goiânia (SEMDUS).

C. Método de Cálculo: Foram utilizadas ferramentas auxiliares como planilhas eletrônicas e Sistema de Informações Geográficas (SIG) para obtenção desse indicador. Foi realizada a filtragem das linhas de ônibus de forma a considerar apenas um único sentido e eliminando sobreposições. Posteriormente foram calculadas a extensão total da rede de transporte público e a extensão total do sistema viário para cada Região Administrativa (R.A.). Os resultados estão apresentados no Quadro 16 e na Tabela 16:

Quadro 16: Escala de avaliação para a variável E.R.T.P. para Goiânia.

\begin{tabular}{|c|l|}
\hline \multirow{2}{*}{$\begin{array}{c}\text { Escala de } \\
\text { Avaliação }\end{array}$} & Valores de Referência \\
\cline { 2 - 2 } & $\begin{array}{l}\text { Extensão da rede de transporte público em relação à } \\
\text { extensão do sistema viário para cada região } \\
\text { administrativa. }\end{array}$ \\
\hline $\mathbf{1}$ & Baixa quantidade de E.R.T.P.: $<40 \%$ \\
\hline $\mathbf{2}$ & Média quantidade de E.R.T.P.: entre 40 e $80 \%$ \\
\hline $\mathbf{3}$ & Alta quantidade de E.R.T.P.: > $80 \%$ \\
\hline
\end{tabular}


Tabela 16: Avaliação para a variável E.R.T.P. para Goiânia.

\begin{tabular}{ccccc}
\hline $\begin{array}{c}\text { Região } \\
\text { Administrativa (RA) }\end{array}$ & $\begin{array}{c}\text { Linha de } \\
\text { Transporte }(\mathbf{m})\end{array}$ & $\begin{array}{c}\text { Extensão Sistema } \\
\text { Viário }(\mathbf{m})\end{array}$ & $\begin{array}{c}\text { Cálculo } \\
(\boldsymbol{\%})\end{array}$ & Avaliação \\
\hline Centro - Campinas & $222.669,55$ & $746.863,59$ & 30 & 1 \\
Leste & $156.188,26$ & $963.353,00$ & 16 & 1 \\
Noroeste & $97.311,04$ & $633.545,76$ & 15 & 1 \\
Norte & $152.365,68$ & $897.568,27$ & 17 & 1 \\
Oeste & $153.438,55$ & $1.077 .299,18$ & 14 & 1 \\
Sudoeste & $161.556,91$ & $1.167 .717,49$ & 14 & 1 \\
Sul & $207.932,53$ & $714.926,05$ & 29 & 1 \\
\hline
\end{tabular}

Os resultados para esta variável informam que, de maneira geral, a extensão da rede de transporte público para Goiânia é relativamente baixa. Entretanto, verifica-se a abrangência do sistema de transporte em toda área urbana analisada, com predominância na área central, por onde passam muitas linhas de transporte público (Figura 41).

Apesar de a análise ter recaído apenas sobre o município de Goiânia, desconsiderando as cidades que fazem parte da Região Metropolitana, é importante compreender o sistema de transporte coletivo como um todo, conforme já colocado anteriormente. Em Goiânia, o sistema funciona de forma integrada abrangendo toda região metropolitana, formada por 18 municípios e denominada Rede Metropolitana de Transporte Coletivo de Goiânia (RMTC). A estrutura física é composta por um sistema tronco-alimentador, constituído por linhas alimentadoras e semiurbanas que atendem aos bairros periféricos e aos municípios que fazem parte da RMG; e linhas troncais que circulam pelos principais corredores. Os terminais de integração permitem a transferência das linhas alimentadoras e semiurbanas para as linhas troncais. Os corredores de transporte coletivo estão inseridos nas vias arteriais da extensa malha viária. Dentre os corredores de transporte coletivo, destacam-se: Corredor Estrutural Leste-Oeste, implantado na Avenida Anhanguera; Corredor Estrutural Norte-Sul, desenvolvido nas avenidas Goiás, 84, 90, 4ª Radial e Rio Verde; corredores das avenidas T-7, T-9, T-63, 85, Mutirão, dentre outros.

O PDG (2007) recomenda o transporte coletivo como modalidade preferencial de deslocamento motorizado no município. Para tanto, devem ser implementadas soluções para ampliar a oferta de transporte coletivo com qualidade, viabilizando uma melhor mobilidade da população por modos coletivos, assim como outros modais, contribuindo para a mobilidade sustentável. 


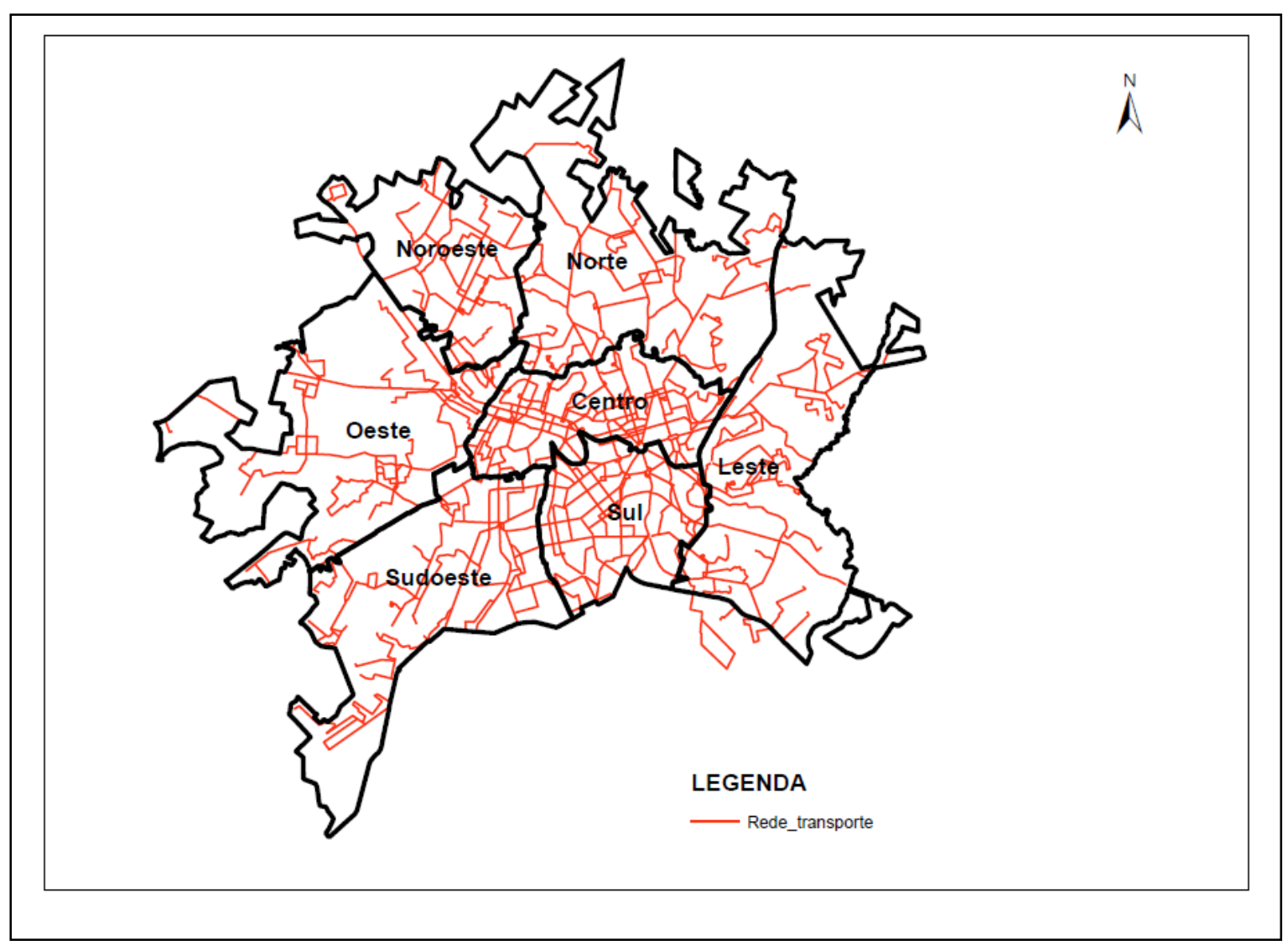

Figura 41: Rede de transporte público em Goiânia.

\section{ii. Acessibilidade ao Transporte Público (A.T.P.)}

A. Definição: Porcentagem da população urbana residente na área de cobertura de um ponto de acesso aos serviços de transporte público, considerando todos os modos disponíveis para cada Região Administrativa de Goiânia.

B. Fontes de Dados: Base georreferenciada com os pontos de ônibus, fornecida pela CMTC e SEPLAM (2014); cadastro dos domicílios urbanos, fornecidos pela CELG (2014).

C. Método de Cálculo: Foram utilizados como ferramentas auxiliares planilhas eletrônicas e SIG. Delimitou-se a área de influência (buffer) de cada ponto de acesso ao sistema de transporte público, correspondendo a um círculo com centro no respectivo ponto de raio de 300 ou 500 metros. O raio de 300 metros foi delimitado em casos de pontos de ônibus, microônibus e vans, enquanto quem o raio de 500 metros foi utilizado para os terminais. Tomou-se o cuidado para não sobrepor as áreas referentes a cada ponto (isso implicaria em dupla contagem da população), criando-se uma mancha única que caracterizou a área total de cobertura do sistema de transporte. De acordo com o IBGE (2010), a média de habitantes por 
domicílio em Goiânia é de 3,07. Os resultados estão apresentados no Quadro 17 e na Tabela 17.

Quadro 17: Escala de avaliação para a variável A.T.P. para Goiânia.

\begin{tabular}{|c|l|}
\hline \multirow{2}{*}{$\begin{array}{c}\text { Escala de } \\
\text { Avaliação }\end{array}$} & Valores de Referência \\
\cline { 2 - 3 } & $\begin{array}{l}\text { Porcentagem da população urbana residente na área } \\
\text { de cobertura de pontos de acesso ao transporte } \\
\text { público. }\end{array}$ \\
\hline $\mathbf{1}$ & $\begin{array}{l}\text { Baixa quantidade de A.T.P.: <32,5\% da população } \\
\text { urbana residente na área de cobertura de pontos de } \\
\text { acesso ao transporte público. }\end{array}$ \\
\hline $\mathbf{2}$ & $\begin{array}{l}\text { Média quantidade de A.T.P... entre 32,5\% e 77,5\% } \\
\text { da população urbana residente na área de cobertura } \\
\text { de pontos de acesso ao transporte público. }\end{array}$ \\
\hline $\mathbf{3}$ & $\begin{array}{l}\text { Alta quantidade de A.T.P.: }>77,5 \% \text { da população } \\
\text { urbana residente na área de cobertura de pontos de } \\
\text { acesso ao transporte público. }\end{array}$ \\
\hline
\end{tabular}

Tabela 17: Avaliação para a variável A.T.P. em Goiânia.

\begin{tabular}{ccccc}
\hline $\begin{array}{c}\text { Região } \\
\text { Administrativa (RA) }\end{array}$ & $\begin{array}{c}\text { Total de } \\
\text { Habitantes R.A. }\end{array}$ & $\begin{array}{c}\text { Total de Habitantes } \\
\text { no Buffer }\end{array}$ & $\begin{array}{c}\text { Cálculo } \\
(\%)\end{array}$ & Avaliação \\
\hline Centro - Campinas & 221.464 & 218.327 & 99 & 3 \\
Leste & 172.436 & 156.788 & 91 & 3 \\
Noroeste & 164.283 & 151.926 & 92 & 3 \\
Norte & 146.677 & 129.074 & 88 & 3 \\
Oeste & 152.189 & 139.788 & 92 & 3 \\
Sudoeste & 223.027 & 206.713 & 93 & 3 \\
\hline Sul & 221.925 & 218.380 & 98 & 3 \\
\hline
\end{tabular}

Em relação à variável verificou-se, por meio dos resultados, que há boa cobertura em todas as regiões, conforme ilustra a Figura 42. Porcentagem significativa da população pode acessar ao ponto de ônibus ou terminal de integração em um raio de 300 a 500 metros, respectivamente. Os terminais de integração, em Goiânia, operam em regime de área fechada (área paga), onde é possível desembarcar de um ônibus e embarcar em outro, sem que seja necessário pagar novamente pela viagem. Dentro da área de análise, verifica-se a presença de 11 terminais que atendem às Regiões Administrativas, conforme ilustra Figura 43: Noroeste, Oeste, Centro-Campinas, Sul, Sudoeste e Leste. Apenas a região Norte não possui um terminal de acesso ao transporte público. 
Esta variável indica acessibilidade física ao transporte público, o que contribui para o aumento da mobilidade da população. A utilização do transporte coletivo reduz a circulação de veículos privados e permite o uso racional do sistema viário.

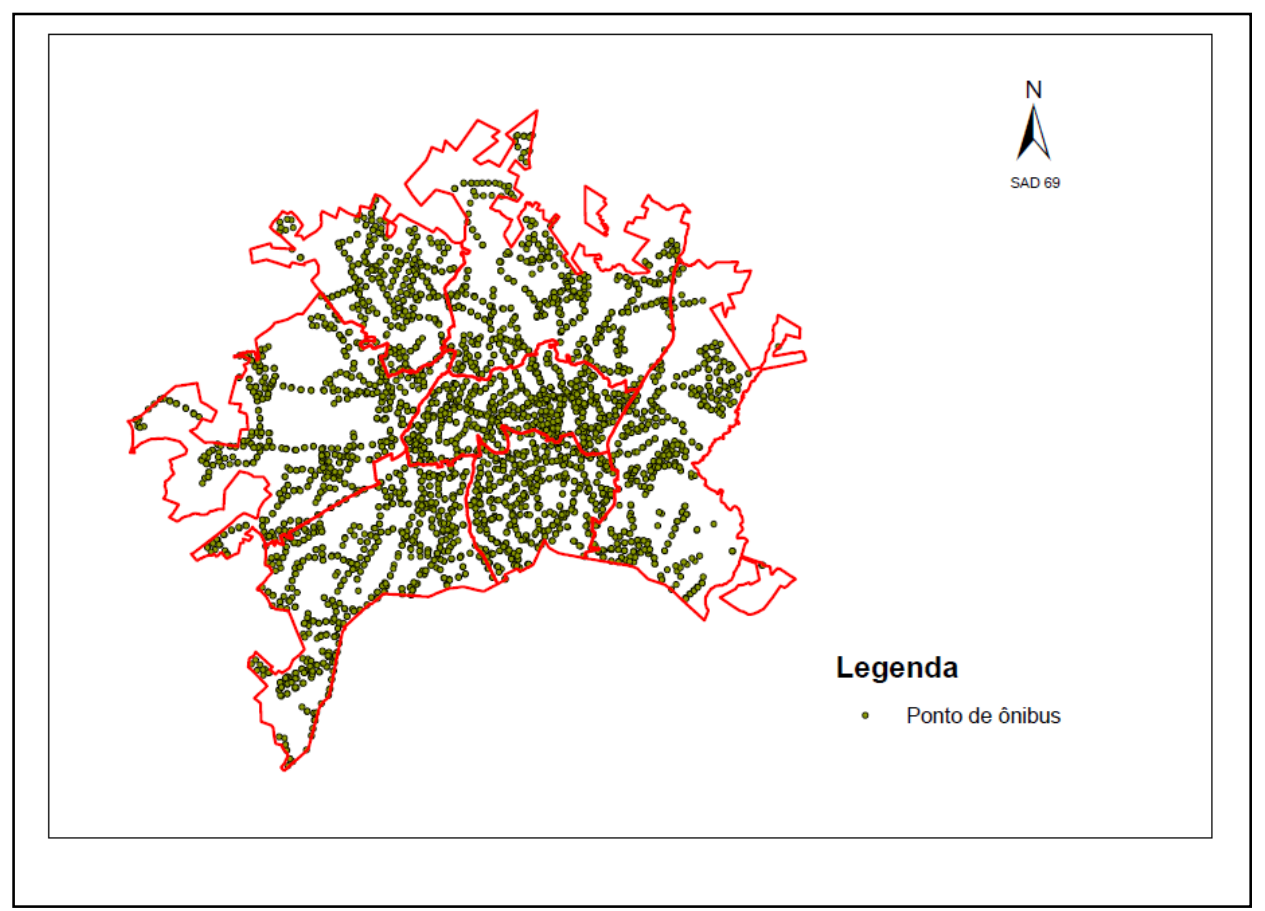

Figura 42: Distribuição dos pontos de ônibus em cada R.A. Elaboração: Autora, (2015).

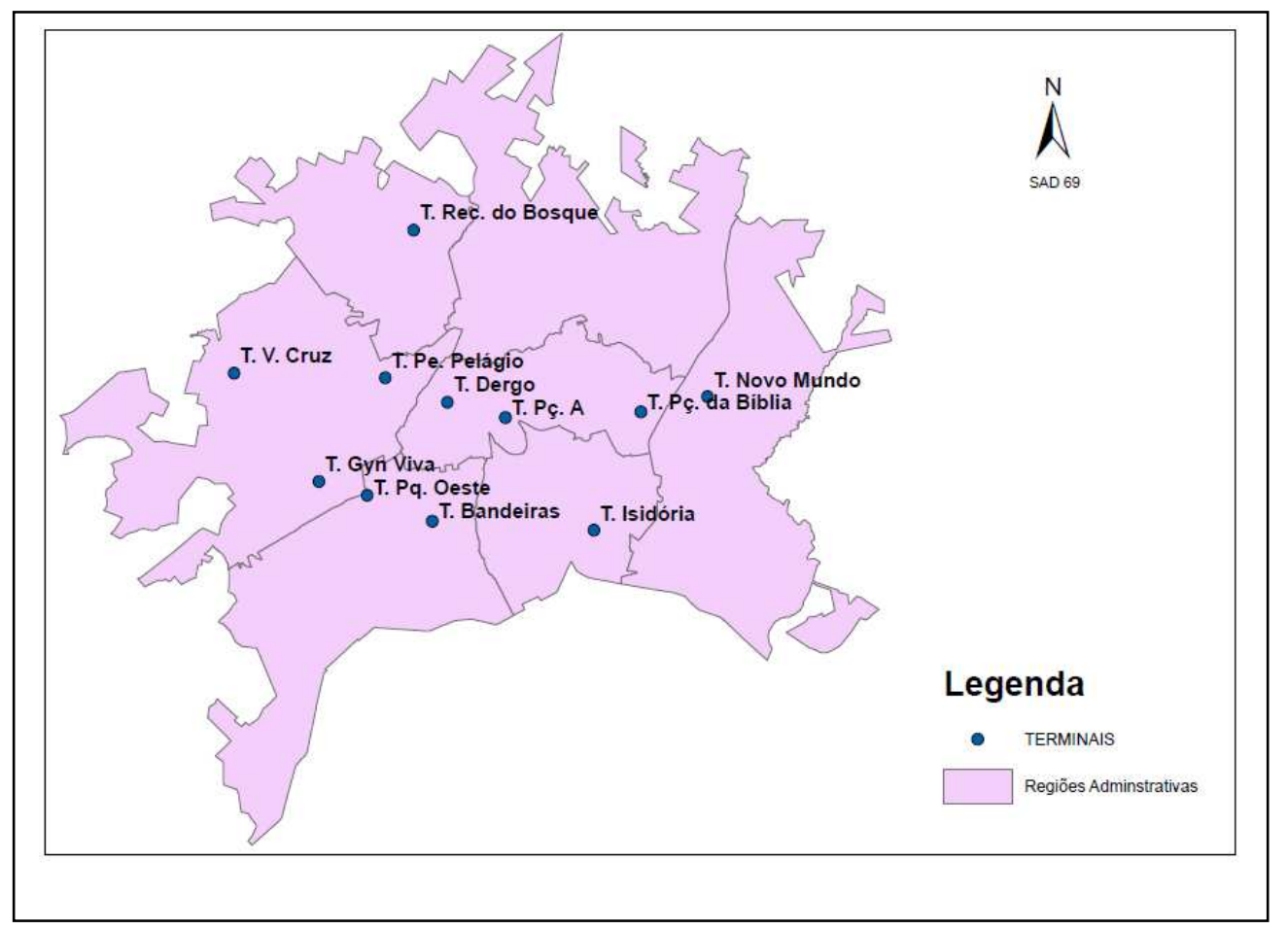

Figura 43: Distribuição dos terminais nas R.A. Elaboração: Autora, (2015). 


\section{iii. Vias para Pedestres (V.P.)}

A. Definição: Cobertura e conectividade da rede de vias para pedestres para cada Região Administrativa em Goiânia.

B. Fontes de Dados: Pesquisa elaborada com técnico da SEMDUS (Secretaria de Desenvolvimento Urbano de Goiânia) e dados que constam na dissertação de Abdala (2013), que calculou o Índice de Mobilidade Urbana Sustentável para Goiânia (IMUS).

C. Método de Cálculo: Por meio dos dados que constam na dissertação de Abdala (2013), já que não havia um levantamento numérico da quantidade e conectividade de vias para pedestres, verificou-se que apenas $2 \%$ do sistema viário total possuem vias especiais ou exclusivas para pedestres (calçadões) e a rede apresenta baixa conectividade. Com base nessa informação, a avaliação para todas as regiões foi estabelecida na categoria 1, conforme apresentam Quadro 18 e Tabela 18.

Quadro 18: Escala de avaliação para o indicador Vias para Pedestres para Goiânia.

\begin{tabular}{|c|l|}
\hline $\begin{array}{c}\text { Escala de } \\
\text { Avaliação }\end{array}$ & \multicolumn{1}{|c|}{ Valores de Referência } \\
\hline \multirow{1}{1}{} & $\begin{array}{l}\text { Baixa quantidade de vias para pedestres: quando não } \\
\text { há na área urbana delimitada para estudo vias } \\
\text { especiais ou preferenciais para pedestres e ou/ até } \\
25 \% \text { do sistema viário urbano são compostos por } \\
\text { vias especiais ou preferenciais para pedestres, } \\
\text { apresentando baixa conectividade. }\end{array}$ \\
\hline $\mathbf{2}$ & $\begin{array}{l}\text { Média quantidade de vias para pedestres: até 25\% } \\
\text { do sistema viário urbano são compostos por vias } \\
\text { especiais ou preferenciais para pedestres, porém, a } \\
\text { rede apresenta alta conectividade. }\end{array}$ \\
\hline $\mathbf{3}$ & $\begin{array}{l}\text { Alta quantidade de vias para pedestres: mais de } \\
25 \% \text { do sistema viário urbano são compostos por } \\
\text { vias especiais ou preferenciais para pedestres e a } \\
\text { rede apresenta alta/baixa conectividade. }\end{array}$ \\
\hline
\end{tabular}


Tabela 18: Avaliação para o indicador Vias para Pedestre para cada R.A. de Goiânia.

\begin{tabular}{cc}
\hline R. A. & Avaliação \\
\hline Centro-Campinas & 1 \\
Leste & 1 \\
Noroeste & 1 \\
Norte & 1 \\
Oeste & 1 \\
Sul & 1 \\
Sudoeste & 1 \\
\hline
\end{tabular}

A variável Vias para Pedestres está relacionada à cobertura e conectividade da rede de vias para pedestres. Em Goiânia, esta variável para todas as Regiões Administrativas apresentou baixo desempenho, tendo em vista que não há provisão de infraestrutura adequada para pedestres, aqui entendidas como vias preferenciais ou caminhos para pedestres e que também atendam à uma série de parâmetros de conforto e segurança de modo a permitir acesso ao sistema de transporte e facilidade nas conexões intermodais. A falta de infraestrutura adequada para pedestres, dentro da árvore de avaliação, combinada com os demais elementos, leva para uma área de baixo desempenho em relação aos elementos de transporte e circulação, refletindo de forma negativa para potencial da mobilidade sustentável. Importa dizer que, não se pretende vincular o desempenho da mobilidade às vias exclusivas para pedestres, afinal foi esse padrão de separar fluxos que levou à pobreza espacial dos assentamentos urbanos modernistas. Entretanto, destinar espaços para circulação adequada de pedestres, inseridos num desenho urbano que possa estimular a utilização dos modos de transporte não-motorizados e o transporte público, pode favorecer ou potencializar a mobilidade sustentável.

\section{iv. Extensão e Conectividade de Ciclovias (E.C.C.)}

A. Definição: Cobertura e conectividade da rede de vias para bicicleta.

B. Fontes de Dados: Base georreferenciada do município fornecidas pela SEMDUS, com sistema viário, levantamento e desenho das ciclovias existentes em Goiânia.

C. Método de Cálculo: Quantificou-se a extensão do sistema viário em cada R.A. Por meio do desenho das ciclovias, verificaram-se dois trechos implantados em Goiânia: 2,5 Km no Corredor Universitário e 5,7 Km na Avenida T-63. Na avaliação, para cada R.A. foram 
consideradas baixa quantidade de ciclovias e baixa conectividade. Uma vez que, são poucos os trechos de ciclovia, não foi procedido o cálculo da razão entre a extensão total de ciclovias e a extensão total do sistema viário urbano. Os resultados são apresentados no Quadro 19 e na Tabela 19.

Quadro 19: Escala de avaliação para o indicador ECC para Goiânia.

\begin{tabular}{|c|l|}
\hline $\begin{array}{c}\text { Escala de } \\
\text { Avaliação }\end{array}$ & \multicolumn{1}{|c|}{ Valores de Referência } \\
\hline \multirow{2}{1}{} & $\begin{array}{l}\text { Baixa quantidade de E.C.C.: } \\
\text { quando não há na área urbana } \\
\text { delimitada para estudo nenhum } \\
\text { trecho de ciclovia ou ciclofaixa } \\
\text { e/ou até 25\% do sistema viário } \\
\text { apresentam ciclovias ou ciclofaixas } \\
\text { e rede com baixa conectividade. }\end{array}$ \\
\hline $\mathbf{2}$ & $\begin{array}{l}\text { Média quantidade E.C.C.: até 25\% } \\
\text { do sistema viário urbano } \\
\text { apresentam ciclovia ou ciclofaixas } \\
\text { e a rede apresenta alta } \\
\text { conectividade. }\end{array}$ \\
\hline $\mathbf{3}$ & $\begin{array}{l}\text { Alta quantidade de E.C.C.: mais de } \\
25 \% \text { do sistema viário urbano } \\
\text { apresentam ciclovias ou } \\
\text { ciclofaixas, e a rede apresenta } \\
\text { alta/baixa conectividade. }\end{array}$ \\
\hline
\end{tabular}

Tabela 19: Avaliação para o indicador ECC para cada R.A. em Goiânia.

\begin{tabular}{cc}
\hline R. A. & Avaliação \\
\hline Centro- & 1 \\
Campinas & \\
Leste & 1 \\
Noroeste & 1 \\
Norte & 1 \\
Oeste & 1 \\
Sul & 1 \\
Sudoeste & 1 \\
\hline
\end{tabular}

O indicador Extensão e Conectividade de Ciclovias também teve baixo desempenho em todas as Regiões Administrativas, tendo em conta que em Goiânia, existem apenas duas ciclovias - não interligadas - somando 8,2 Km: 2,5 Km no Corredor da Avenida Universitária e 5,7 Km no Corredor da Avenida T-63. Entretanto, existe um projeto para conectividade dessas duas ciclovias, que começará a ser implantado a parti de fevereiro de 2015, somando- 
se ao sistema, aproximadamente, $23 \mathrm{Km}$ de novos trechos. $\mathrm{O}$ incentivo ao uso e a provisão de infraestrutura adequada para circulação de pedestres e ciclistas são ações de extrema importância para potencializar a mobilidade sustentável. Em Goiânia, as iniciativas nesse sentido ainda são tímidas, apesar de haver projetos e do tema ser tratado no PDG. A cidade apresenta boa topografia e clima agradável para andar de bicicleta. A conectividade dos caminhos para bicicleta, além disso, é um importante aspecto a ser promovido, a fim de ampliar a rede de opções para deslocamentos por meio de modos não-motorizados. 
4.4.5 Agregação das variáveis do Eixo de Análise II - Árvore de Avaliação: Mapa Síntese "Transporte e Circulação"

A agregação das variáveis deste eixo de análise será conduzida por meio da Árvore de Avaliação apresentada na Figura 44:

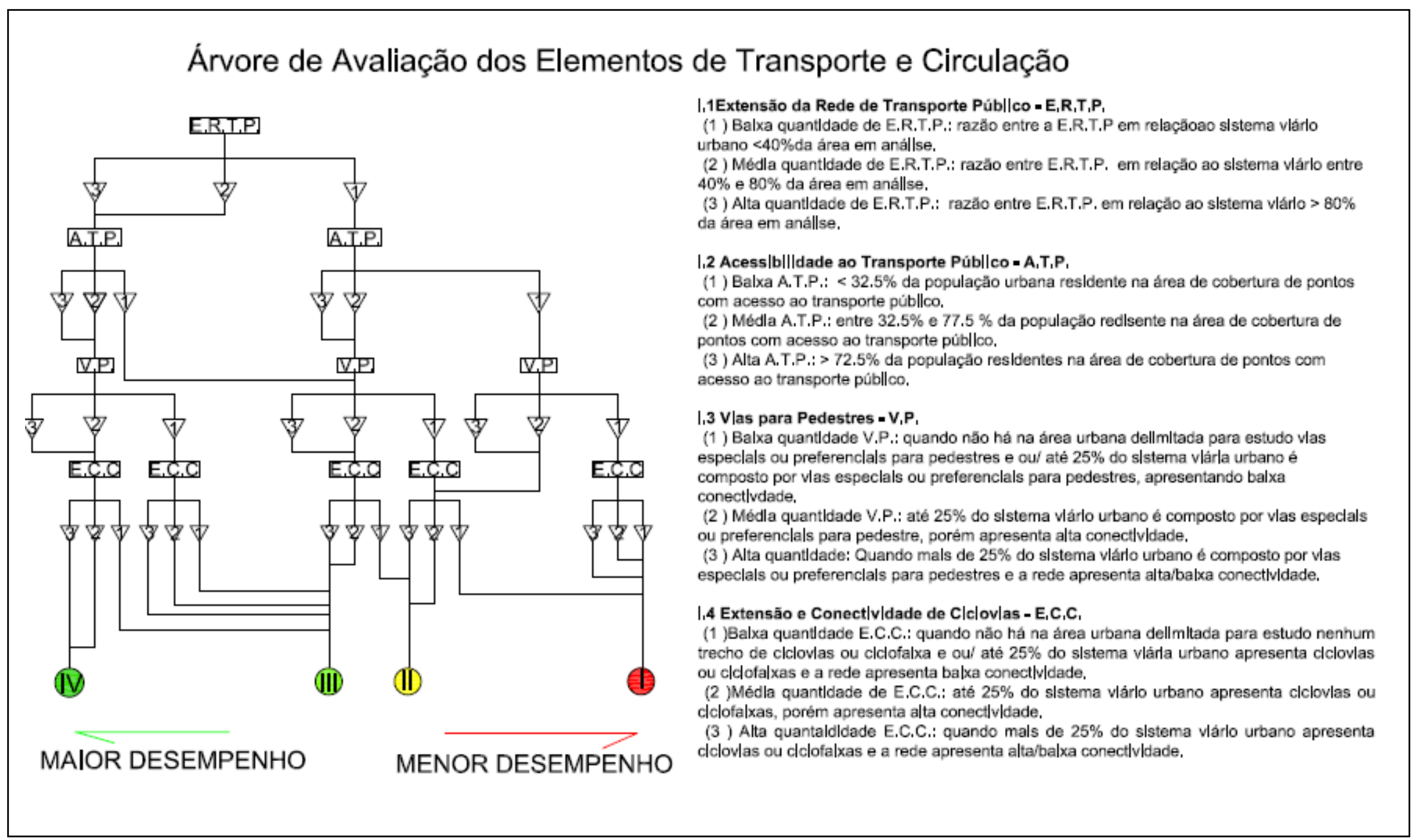

Figura 44: Árvore de avaliação para agregação das variáveis dispostas no Eixo de Análise "Transporte e Circulação". Elaboração: Autora (2014). 
De acordo com os resultados obtidos para cada variável (Tabela 20) e utilizando-se da Árvore de Avaliação proposta para o "Transporte e Circulação" ilustrada na Figura 44, foi possível espacializar e combinar cada variável em ordem hierárquica. A Figura 46 ilustra a espacialização e o resultado das combinações no "Mapa Síntese dos Elementos de Transporte e Circulação".

Tabela 20: Resumo da avaliação das variáveis para cada R.A em Goiânia.

\begin{tabular}{lccccc}
\hline \multicolumn{1}{c}{ Indicadores } & E.R.T.P. & A.T.P. & V.P. & E.C.C. & Avaliação "Transporte e Circulação" \\
\hline RA & & & & & I \\
\hline Lentro Campinas & 1 & 3 & 1 & 1 & I \\
Noroeste & 1 & 3 & 1 & 1 & I \\
Norte & 1 & 3 & 1 & 1 & I \\
Oeste & 1 & 3 & 1 & 1 & I \\
Sudoeste & 1 & 3 & 1 & 1 & I \\
Sul & 1 & 3 & 1 & 1 & I \\
\hline
\end{tabular}

A Figura 45 ilustra o caminho percorrido na árvore de avaliação para Região Administrativa Centro-Campinas, assim a análise foi feita para as demais áreas.

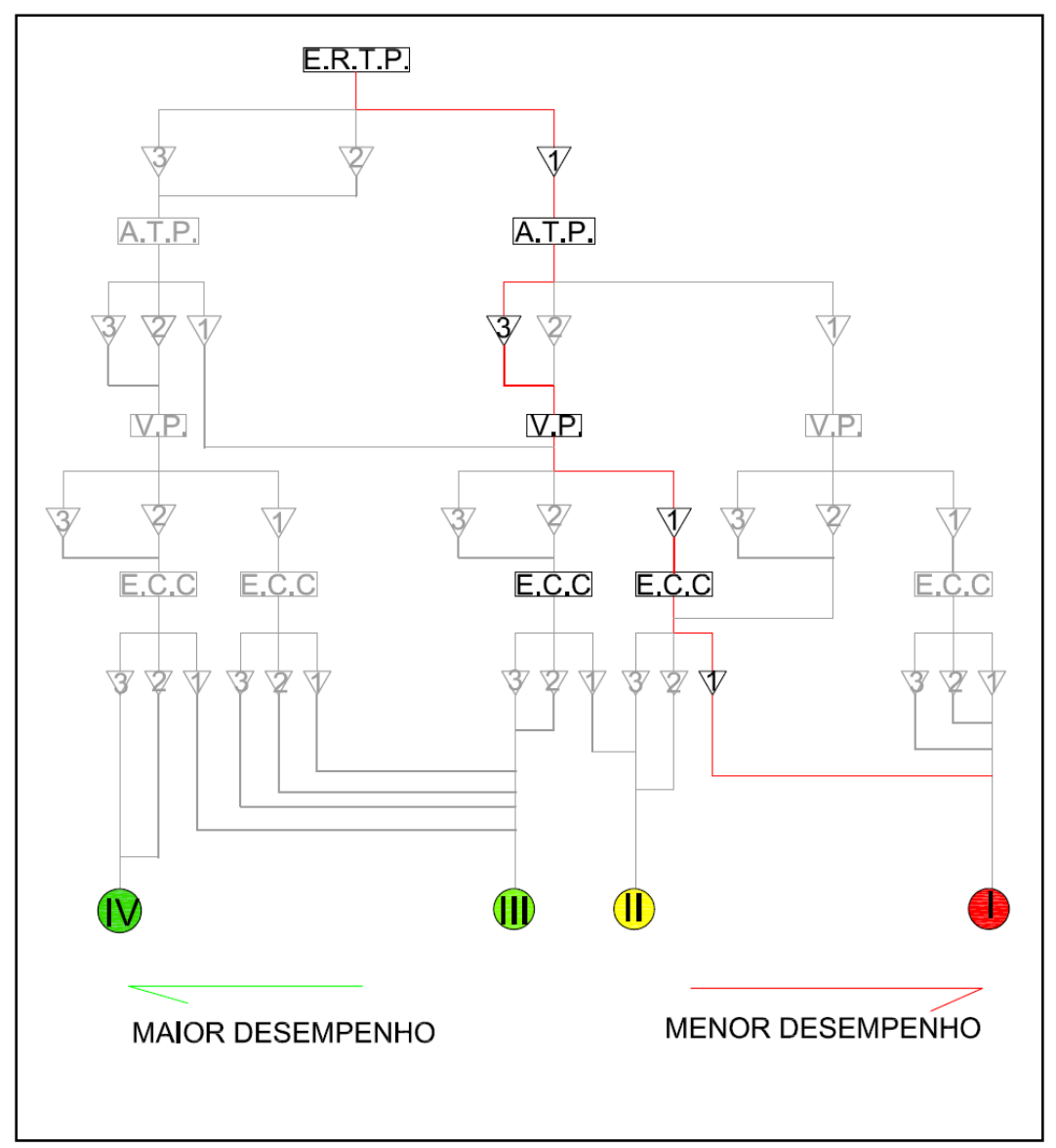

Figura 45: Caminho percorrido na árvore de avaliação para R.A. Centro - Campinas. 
A espacialização dos resultados demonstra, em relação às variáveis que compõem a estrutura proposta para os Elementos de Transporte e Circulação, desempenho insuficiente para todas as Regiões Administrativas. Apenas a variável Acessibilidade ao Transporte Público, alcançou resultados positivos. Com isso, o mapa síntese expressa que há um baixo potencial em relação aos elementos de transporte e circulação para todas as R.A. Esse resultado, ao ser combinado por meio da matriz de agregação com os resultados da Forma Urbana, implicará em áreas com menor potencial para mobilidade sustentável, conforme se verá a seguir. Essas análises serão aprofundadas no próximo item, em que será apresentada a matriz de agregação e o "Mapa Potencial de Mobilidade Sustentável”. 


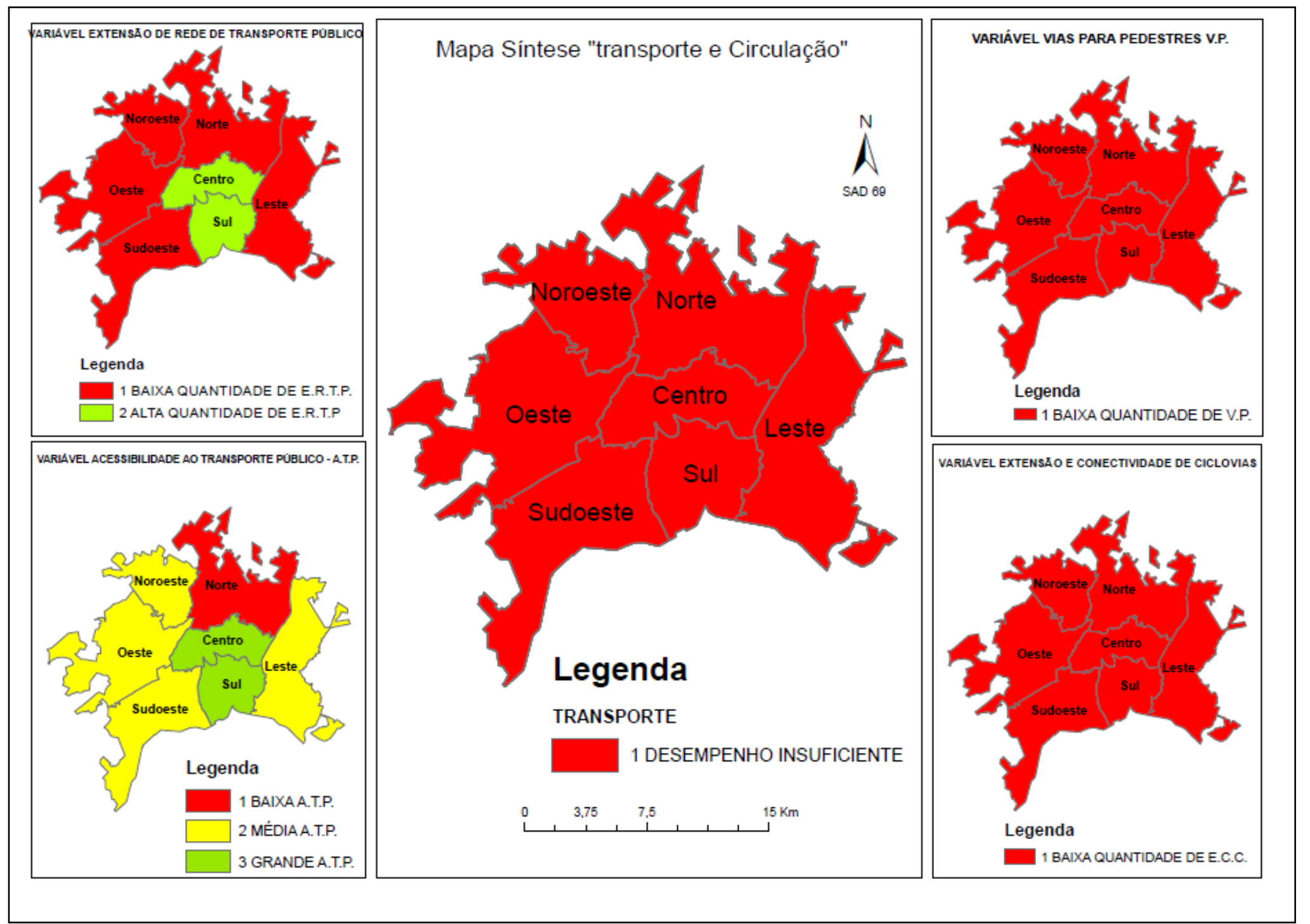

Figura 46: Mapa síntese da Forma Urbana. Espacialização dos resultados para todas as variáveis do Eixo de Análise I. Elaboração: Autora (2014). 
4.4.6 Matriz de potencial de mobilidade: combinação dos eixos de análise I e II

Para avaliar o potencial de mobilidade sustentável das Regiões Administrativas de Goiânia, foi utilizada a matriz de agregação ilustrada na Figura 47. Conforme descrito no Capítulo 3 (cf. item 3.3.3), a matriz funciona como um filtro, e contém a combinação dos níveis da "Forma Urbana", relacionados aos níveis "Transporte e Circulação" e vice-versa, gerando, desta maneira, o "Potencial de Mobilidade Sustentável". A matriz foi produzida em consonância com as informações expostas no Capítulo 2, sobre forma e mobilidade, quando se demonstra que características da compacidade auxiliam na promoção de mobilidade urbana sustentável. As combinações possuem quatro níveis: insuficiente, baixo, médio e alto potencial e, para cada um deles, devem ser propostas medidas de acordo com os resultados alcançados para cada variável.

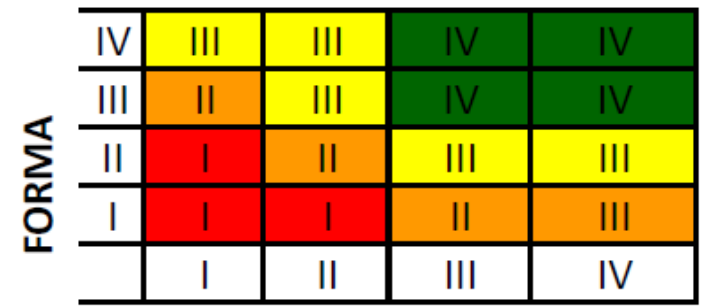

TRANSPORTE

\begin{tabular}{c|c|c|}
\hline I & $\begin{array}{c}\text { Área com potencial insuficiente } \\
\text { para mobilidade urbana } \\
\text { sustentável - Necessário verificação } \\
\text { dos elementos da forma } \\
\text { urbana/elementos de transporte e } \\
\text { circulação. }\end{array}$ \\
\hline II & $\begin{array}{c}\text { Área com baixo potencial para } \\
\text { mobilidade urbana sustentável - } \\
\text { da forma urbana/elementos de } \\
\text { transporte e circulação. }\end{array}$ & \\
\hline III & $\begin{array}{c}\text { Área com médio potencial para } \\
\text { mobilidade urbana sustentável. } \\
\text { da forma urbana/elementos de } \\
\text { transporte e circulação. }\end{array}$ & \\
\hline IV & $\begin{array}{c}\text { Área com alto potencial para } \\
\text { mobilidade urbana sustentável. }\end{array}$ & \\
\hline
\end{tabular}

Figura 47: Matriz de Agregação para avaliar o Potencial de Mobilidade Sustentável. Elaboração: Autora (2014).

A Tabela 21, apresenta a síntese dos resultados obtidos para avaliação das variáveis contidas nos Eixos de Análise "Forma Urbana" e "Transporte e Circulação". A coluna "Potencial de Mobilidade Sustentável" mostra a combinação das duas árvores, consolidada por meio da matriz apresentada na Figura 47. A Figura 48, por outro lado, ilustra a espacialização desses resultados: 
Tabela 21: Resultado "Potencial de Mobilidade Sustentável" para cada R.A em Goiânia.

\begin{tabular}{lccc}
\hline \multicolumn{1}{c}{ Indicadores } & $\begin{array}{c}\text { Avaliação } \\
\text { Rorma Urbana }\end{array}$ & $\begin{array}{c}\text { Avaliação } \\
\text { Transporte } \\
\text { Circulação }\end{array}$ & $\begin{array}{c}\text { Potencial de } \\
\text { Mobilidade } \\
\text { Sustentável }\end{array}$ \\
\hline $\begin{array}{l}\text { Centro }- \\
\text { Campinas }\end{array}$ & IV & I & III \\
Leste & II & I & I \\
Noroeste & II & I & I \\
Norte & II & I & I \\
Oeste & II & I & I \\
Sudoeste & IV & I & III \\
Sul & IV & I & III \\
\hline
\end{tabular}




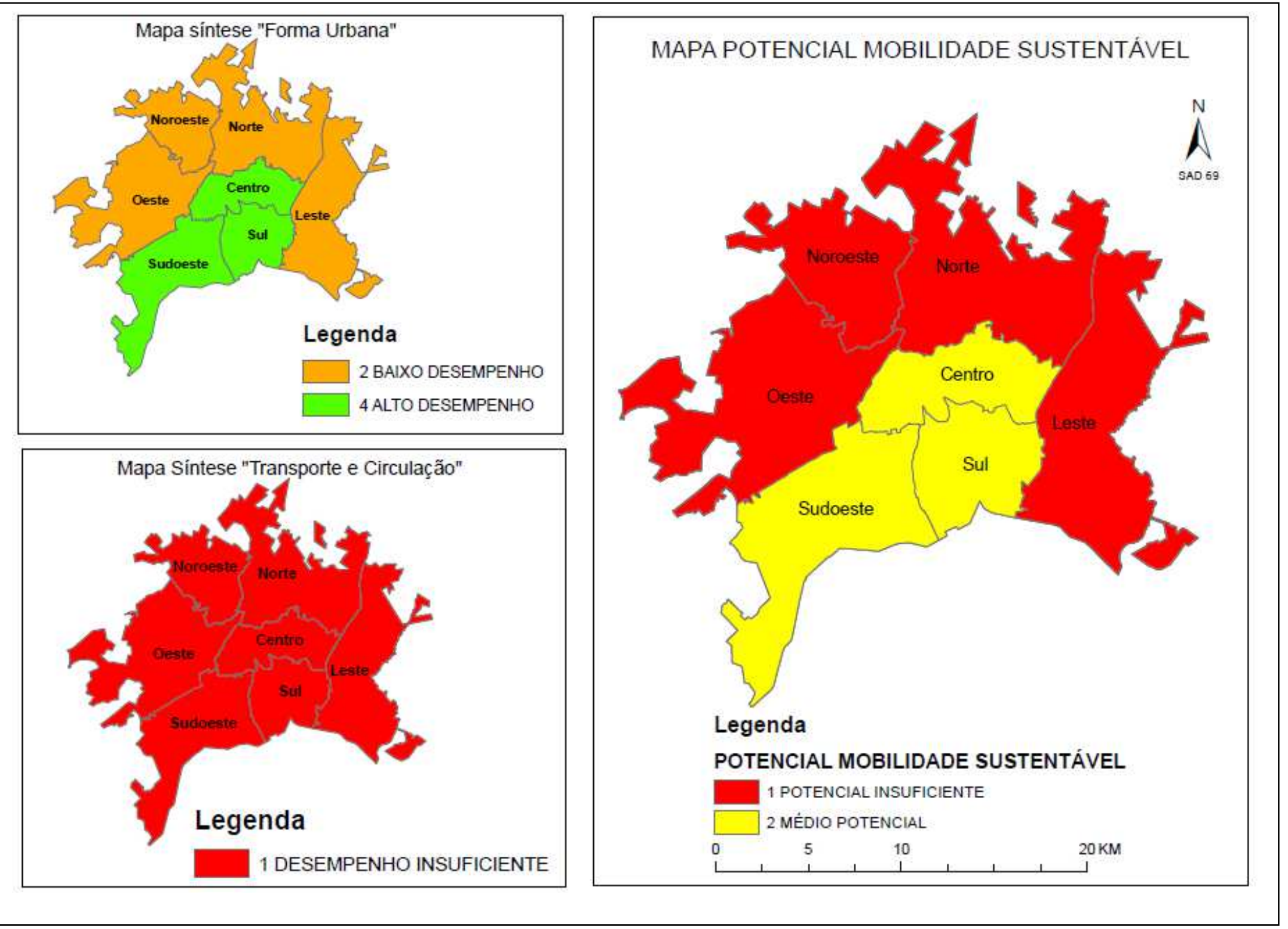

Figura 48: Mapa Potencial Mobilidade Sustentável para Goiânia. Elaboração: Autora (2014). 
De acordo com os resultados, verifica-se que as regiões Centro, Sul e Sudoeste apresentam uma melhor combinação entre os elementos da Forma Urbana e de Transporte e Circulação, atingindo um Médio Potencial para Mobilidade Sustentável. As demais Regiões Administrativas, por outro lado, apresentaram Baixo Potencial para Mobilidade Sustentável.

Da análise das variáveis que compõem a forma urbana, observou-se que CentroCampinas e Sul correspondem às áreas com maior densidade populacional, maior diversidade de uso do solo urbano, menor número de vazios e que concentram as vias mais integradas e acessíveis do sistema urbano. As demais regiões também apresentaram bom desempenho, entretanto, torna-se necessário estimular maior adensamento nesses locais para que seja possível sentir efeitos mais positivos em relação ao uso misto, redução de vazios e articulação das vias para torná-las mais integradas e acessíveis (o que promoveria a criação de novas centralidades na área urbana de Goiânia).

Com relação aos elementos de Transporte e Circulação, de acordo com a avaliação proposta, obteve-se baixo desempenho para todas as Regiões Administrativas. Esse resultado refletiu na avaliação final, porque, quando se combinam Forma e Transporte por meio da matriz, apenas as regiões Centro-Campinas, Sul e Sudoeste atingiram um médio desempenho; com todas as demais situadas no grupo de baixo desempenho.

4.4.7 Resultados: proposição de medidas de planejamento e desenho urbano.

O Plano Diretor de Goiânia apresenta propostas quanto aos elementos da forma urbana que indicam um bom potencial para mobilidade urbana. Entretanto, falta planejamento integrado que considere os aspectos urbanísticos (sistema da forma urbana) e de transporte para uma melhor reposta do espaço urbano quanto à mobilidade de pessoas e bens. Alguns problemas referentes ao transporte e à circulação podem ser citados:

i. Pouca infraestrutura implantada para transporte não-motorizado: existência de apenas $8,2 \mathrm{~km}$ de ciclovias, que compreendem 2,5 km entre a Praça Cívica e a Praça a Bíblia e 5,7 Km na Avenida T-63. Com relação às calçadas, percebe-se pouco ou nenhum cuidado com a execução das mesmas. De modo geral, a qualidade dos espaços destinados aos pedestres e ciclistas é precária;

ii. Com relação ao transporte público, verifica-se que, atualmente, Goiânia conta com alguns corredores exclusivos já implantados: Corredor Exclusivo Leste-Oeste 
conhecido com Eixo Anhanguera, que opera como BRT (Bus Rapid Transit), e Corredor Universitário, que liga a Praça Cívica à Praça da Bíblia, correspondendo ao mesmo trecho de ciclovia já mencionado; e o Corredor da Avenida T-63. Sabese que mais cincos corredores (T-9, T-7, Avenida 85, Avenida 24 de outubro e Avenida Independência) já estão com o projeto básico concluído (NTU, 2013). A considerar o contexto de mobilidade urbana da cidade, seria importante que fossem implantados rapidamente, já que promoveriam aumento da velocidade, maior eficiência e menor ociosidade do sistema de transporte. Destinar espaços exclusivos da via para transporte público resolve parte dos problemas relativos à mobilidade e melhora a qualidade de vida da população, o que contribui para promoção de uma cidade sustentável. Entretanto, cabe mencionar que, grosso modo, o transporte coletivo é ineficiente, transporta mais passageiros que sua capacidade, com lotação máxima excedida e quantidade de ônibus insuficiente em determinadas linhas no horário de pico. Esses e outros fatores desestimulam a utilização do transporte público, fazendo com que cada vez mais as pessoas busquem o automóvel como meio para se deslocar.

Assim, apesar de o Plano Diretor (2007) trazer contribuições positivas para mobilidade, não existe, ainda, o Plano de Mobilidade de Goiânia, obrigatório conforme estabelecido na Lei $n^{\circ} 12.587$ de 03 de janeiro de 2012, que estipulou o prazo máximo de 3 anos a partir de sua vigência para sua elaboração.

O Procedimento de Análise Espacial do potencial de mobilidade pode ser um instrumento de apoio ao plano, por integrar as proposições de estruturação física da cidade, típicas do plano diretor, àquelas que normalmente compõem os planos de mobilidade como afetas ao que se denominou de sistema de Transporte e circulação. O procedimento pode indicar elementos tanto referentes ao planejamento urbano quanto ao planejamento de transportes que possam dotar as áreas urbanas de um padrão mínimo de requisitos que potencializem a mobilidade sustentável. 
4.4.7.1 Propostas de integração entre os sistemas "Forma Urbana" e "Transporte e Circulação"

A última etapa do Procedimento de Análise Espacial é a proposição de medidas que podem apoiar o planejamento e o desenho urbano com vistas a um melhor desempenho da mobilidade, tendo em conta os resultados do Mapa Potencial da Mobilidade Sustentável, e de cada uma das variáveis que formam os Eixos de Análise I e II. Para melhor entendimento, seguem abaixo as proposições, por Eixo de Análise:

\section{- Sistema Forma Urbana:}

Aumento da densidade, de forma qualificada e de modo que haja um equilíbrio na distribuição das densidades nas Regiões Administrativas que obtiveram pior desempenho. Neste caso, sugere-se uma análise mais detalhada, considerando a população de cada bairro que compõem a R.A. para verificar as áreas menos populosas, além disso, é necessário redução de vazios e melhor articulação do desenho urbano.

Ao se calcular a densidade populacional em Goiânia, foi possível perceber que, dentro de uma mesma R.A a população é bastante heterogênea no que diz respeito à quantidade de habitantes, ou seja, há bairros com muitas pessoas, enquanto o inverso também acontece. $\mathrm{O}$ fato influenciou no resultado da densidade urbana, pois se considera nos cálculos a área da Região Administrativa e não a área de cada bairro. Com isso, mesmo nas regiões com desempenho melhor, como o caso do Centro-Campinas e Sul, as densidades são relativamente baixas, pois se diluem no conjunto.

Entretanto, se a unidade de análise fosse o bairro, as densidades seriam maiores, como os casos de Jardim América, Bueno, Pedro Ludovico, Central, Leste Universitário e outros, todos localizados nas regiões Centro-Campinas e Sul. A questão reforça a necessidade de incentivar maiores densidades em todas as Regiões Administrativas, exceto nas áreas em que, por Lei, já se restringe o adensamento, pois existem bairros localizados principalmente, nas regiões Oeste, Leste, Noroeste e Norte, com baixas densidades, muitos vazios e pouca infraestrutura. A manutenção de densidades elevadas constitui-se em importante fator para controlar o espalhamento urbano, viabilizando a implantação de sistema de transporte mais eficientes.

As variáveis densidade populacional, uso do solo urbano, vazios e desenho urbano possuem certa correspondência nas regiões Centro-Campinas e Sul, apresentando resultados positivos, uma vez que ali existem as maiores densidades, uso misto do solo e menor quantidade de vazios. Em relação aos valores de integração global que respondem pela 
avaliação da variável desenho urbano, verificou-se que as vias mais integradas também estão presentes no Centro e Sul. Considera-se que valores de integração maiores podem auxiliar o aumento da fluidez em razão de uma malha viária mais articulada, melhorando a acessibilidade e podendo contribuir, inclusive, na proposta de um transporte coletivo mais eficiente.

Todas as variáveis da Forma Urbana também apresentaram desempenho regular nas demais R.A., o que reforça a criação de medidas por meio do plano diretor para reduzir os vazios e aumentar a densidade populacional nos bairros que compõe as R.A. Leste, Oeste, Noroeste e Norte.

Em relação ao desenho urbano, verifica-se que a malha viária de Goiânia é fragmentada, composta por várias grelhas, fruto da ausência de controle durante o processo de expansão urbana. Essa configuração reduziu o número de eixos globais, e, em função disso, as Regiões Administrativas tiverem desempenho ruim em relação à variável desenho urbano. Sugere-se aqui intervenção no desenho da malha viária, para que se possa criar eixos mais integrados e acessíveis, passando por toda a área urbana de Goiânia, permitindo a implantação de um sistema de transporte público articulado em toda a cidade, favorecendo a formação de outras centralidades e melhorando a estruturação viária numa perspectiva global.

Para além disso, vale ressaltar que a variável integração global também indica possíveis centralidades, o que reforça o fato de estimular subcentros como uma política importante. Segundo Kneib (2014), uma cidade considerada sadia é composta por diversos subcentros de portes distintos, que concentram atividades variadas, criando oportunidades para que as pessoas possam desenvolver suas atividades em locais próximos de suas residências, evitando longos deslocamentos diários. Ainda de acordo com Kneib (2014), quando se criam centralidades conectadas e planejadas, é possível realizar pequenos deslocamentos a pé, médios deslocamentos com bicicletas e transporte público, estabelecendo uma rede de mobilidade com diversos modos complementares, o que racionaliza o uso do transporte individual.

Sugere-se que, por meio da revisão do Plano Diretor de Goiânia (PDG), sejam criados instrumentos para reduzir os vazios, atingir níveis de densidade maiores, e que também sejam introduzidos elementos que possam auxiliar o ordenamento territorial, a partir da disposição de novos loteamentos. É fundamental estabelecer a continuidade de novos assentamentos ao sistema viário existente, já que a conexão de todas as regiões que compõem a área urbana de Goiânia pode ser um instrumento tanto do planejamento urbano quanto do planejamento em transporte, para melhorar as condições de mobilidade e acessibilidade na cidade. 


\section{- Sistema Transporte e Circulação}

Em relação à avaliação das variáveis que compõem o Eixo de Análise “Transporte e Circulação", verificou-se baixo desempenho do conjunto. Os resultados demonstram claramente que Planejamento Urbano e de Transporte desarticulados impendem o alcance de cenários positivos de mobilidade urbana. Verificou-se, por meio dos resultados, que é necessário planejar a rede de transporte público em Goiânia: a disponibilidade tanto em termos quantitativos ou qualitativos é essencial para mobilidade sustentável.

A recomendação da obrigatoriedade de a rede do transporte público atender todas as Regiões Administrativas, de modo a possibilitar o atendimento de qualquer desejo de viagem, para qualquer destino, em toda região metropolitana. O planejamento de um sistema de transporte é uma via de mão dupla, pois pode implicar impactos relacionados à fragmentação e à segregação urbana, especialmente no caso de corredores de ônibus segregados. Com isso, é importante estabelecer um planejamento adequado, principalmente em relação à interface com os transportes não-motorizados.

Outro problema detectado foi a ausência de infraestrutura para o transporte nãomotorizado. Identificou-se um projeto piloto (as duas ciclovias construídas presentes no Corredor Universitário e T-63), que ainda não estão interligadas entre si. Cabe também estabelecer rede de vias especiais para pedestres: vias exclusivas (calçadões), vias com prioridade para circulação, rotas especiais (relacionadas a pontos turísticos ou patrimônio histórico), rampas e passarelas em vias públicas e calçadas que apresentem segregação física em relação ao espaço destinado à circulação de veículos.

Por fim, vale reforçar que a conectividade dos caminhos é um aspecto essencial a ser verificado, principalmente em áreas de grande circulação de pessoas. A falta de conectividade da rede implica em desconforto e insegurança, desestimulando deslocamentos por meio dos transportes não-motorizados.

\subsection{Considerações finais do capítulo}

O capítulo tratou da aplicação do Procedimento de Análise Espacial no município de Goiânia, em que foram desenvolvidas 3 etapas de avaliação: a primeira tratou da definição da escala de análise; a segunda foi composta pela agregação das variáveis que levam à composição de cada uma das árvores de interpretação - "Forma Urbana" e "Transportes e Circulação "; a terceira etapa compreendeu a combinação das árvores numa matriz de agregação, obtendo-se o "Mapa Potencial de Mobilidade Sustentável” para Goiânia. 
Com a aplicação do Procedimento de Análise Espacial, foi possível observar as características para cada Região Administrativa e para cada variável proposta nas árvores de avaliação. A espacialização dos resultados permitiu verificar o desempenho da mobilidade sustentável em relação às variáveis propostas.

Os resultados, no que diz respeito ao conjunto das variáveis que compõem o sistema "Forma Urbana", mostraram-se com baixo e médio desempenho. Constata-se, por meio da espacialização dos resultados, que as políticas correlatas adotadas pelo PDG foram importantes para criar espaços urbanos com maior potencial de mobilidade. Isso não implica, entretanto, que os mesmos tenham boa mobilidade, pois resta analisar a agregação com o sistema Transporte e Circulação.

Ao se analisar o sistema "Transporte e Circulação" verifica-se que o eixo não apresentou bom desempenho. Portanto, quando se agrega os dois eixos de análise, por meio da matriz, o Potencial de Mobilidade Sustentável para todas as Regiões Administrativas cai para Zonas II e III, consideradas como de médio e baixo potencial para mobilidade sustentável.

O resultado demonstra que um alto índice de mobilidade necessita de bom desempenho dos dois sistemas, pois são interdependentes, demonstrando que a forma urbana não deve ser menosprezada como uma variável secundária. 


\section{CAPÍTULO 5: RESULTADOS CONCLUSIVOS, POTENCIAL E LIMITAÇÕES DA PESQUISA.}

\section{INTRODUÇÃO}

Este capítulo apresenta as contribuições da pesquisa, correlacionando os resultados com as questões motivadoras da tese expostas no início do trabalho. É intenção explorar as potencialidades e limitações dos estudos e análises procedidas, assim como das recomendações e sugestões de pesquisas futuras, possíveis a partir do desenvolvimento da tese.

\subsection{Resultados}

A pesquisa procurou investigar, por meio da literatura sobre forma urbana, as variáveis que poderiam influenciar a mobilidade sustentável, de modo que fosse possível elaborar uma proposta de análise espacial da mobilidade.

A principal contribuição deste trabalho consistiu na identificação das variáveis de "Forma Urbana" e de "Transporte e Circulação" afetas a estrutura urbana. Entendeu-se que tais categorias seriam potencialmente facilitadoras da mobilidade e por isso importariam na construção de um Procedimento de Análise Espacial que permitisse a verificação de correlação entre a mobilidade e essas variáveis. Partiu-se do princípio de que a abordagem serviria para comprovar sua relevância e, assim, gerar insumos ao planejamento urbano.

A avaliação do desempenho por meio do Procedimento de Análise Espacial apresentado pode revelar o potencial da mobilidade sustentável, considerando aspectos da Forma Urbana e Transporte e Circulação mais relevantes para o planejador. A ação demonstrou diferenças desse potencial quando as variáveis do sistema Forma Urbana e Transporte e Circulação são arranjadas pelas decisões tomadas sobre a estrutura da cidade.

Os resultados alcançados decorreram dos passos metodológicos estruturantes da pesquisa que corroboraram o objetivo definido de: "desenvolver um Procedimento de Análise para explorar o desempenho da forma urbana em relação à mobilidade urbana sustentável para o planejamento urbano”.

Além de atender ao objetivo geral citado, o Procedimento de Análise Espacial possibilitou atender aos seguintes objetivos propostos na metodologia de trabalho, descritos no item 1.5 e que guiaram a pesquisa: 
- Elaboração do referencial teórico, apresentado no Capítulo 2, do qual foi possível determinar as variáveis para estudo e os dois Eixos de Análise: Forma Urbana e Transporte e Circulação; para tanto, foi utilizada a teoria sobre cidade compacta e dispersa;

- Proposta de um Procedimento de Análise Espacial no Capítulo 3, que permitiu relacionar as variáveis da Forma Urbana com as de Transporte e Circulação, indicando as áreas com maior Potencial para Mobilidade Sustentável;

- Aplicação do Procedimento de Análise Espacial na cidade de Goiânia para avaliar o Potencial de Mobilidade sustentável. Por meio dos resultados, foram propostas medidas de controle para a área em questão. Além disso, foi possível avaliar a mobilidade urbana frente às variáveis da forma urbana, identificando cenários que podem ser potencializados em processos de Planejamento Urbano;

- E, por fim, para cada variável analisada no Capítulo 4 pôde-se fornecer subsídios para elaboração de políticas, considerando o Plano Diretor de Goiânia, com ações importantes para potencializar a mobilidade sustentável, tendo em conta as dimensões da sustentabilidade e os aspectos relacionados ao planejamento urbano.

Ressalta-se ainda a contribuição deste Procedimento de Análise Espacial, por permitir tanto uma análise espacializada da mobilidade como uma abordagem centrada num número reduzido e comprovadamente relevante de variáveis para identificar o potencial de mobilidade de uma estrutura urbana.

Mais uma vez, vale destacar que parte significativa dos trabalhos sobre o tema explora um número muito amplo e diversificado de variáveis (política, gestão e até comportamento da população), gerando, quase sempre, índices complexos. Resta a difícil tarefa ao planejador urbano em estabelecer uma priorização de perspectiva, para adotar num contexto de limitação de tempo e recurso, por exemplo.

Em relação às questões de pesquisa, é importante esclarecer os seguintes achados:

i. A forma urbana traduzida no modelo de cidade compacta ou cidade dispersa pode influenciar os padrões de mobilidade urbana sustentável? De acordo com os resultados da aplicação do Procedimento de Análise Espacial do potencial de mobilidade em Goiânia, foi possível verificar que as áreas com médio potencial para mobilidade sustentável reúnem as características da forma compacta: são áreas mais densas, com menor quantidade de vazios, caracterizada por uso misto e por um desenho urbano mais favorável à acessibilidade; além disso, apesar da avaliação para infraestrutura de transporte e circulação ter sido de baixo 
desempenho, é nessas áreas que se encontra a melhor infraestrutura de transporte público. Por meio das análises realizadas pelo Procedimento de Análise Espacial e referencial teórico discutido na tese, é possível assumir que a forma urbana pode, sim, influenciar os padrões de mobilidade sustentável. Assim, a proposição das variáveis (Cf. item 2.6, Quadro 9) foi comprovada pela construção e posterior aplicação do Procedimento de Análise Espacial do potencial de mobilidade na cidade de Goiânia.

ii. Que elementos relativos à forma urbana e mobilidade urbana podem auxiliar para que se possa estabelecer um conjunto de variáveis relevantes para a criação de diretrizes que auxiliem no processo de planejamento urbano? Comprovada a relevância das variáveis da forma urbana acima referidas, é possível, utilizando o Procedimento de Análise Espacial proposto, para verificar se determinada área urbana está ou não dotada das características da forma que potencializem a mobilidade. Diante dessa informação, pode-se proceder simulações de alteração das variáveis para, numa proposta de plano diretor, construir cenários que promovam a mobilidade. De forma resumida, faz-se relevante o levantamento dos elementos da forma urbana apontados pela pesquisa para que os mesmos sejam alterados, influenciando na melhoria da mobilidade. Diante disso, criar diretrizes para os Planos Diretores Urbanos e de Transporte que orientem a criação de espaços urbanos com características que possam potencializar a mobilidade sustentável.

Desta forma, a premissa inicial que fundamentou a pesquisa mostrou-se adequada, pois, se verificou a interpendência entre elementos que compõe "Forma Urbana" e "Transporte e Circulação". A partir do estabelecimento dessas relações, foi possível um novo tipo de procedimento analítico que pudesse tratar da forma urbana e do transporte de maneira equitativa e agregada. Percebeu-se que a forma urbana exerce tanta influência em bons padrões de mobilidade quanto a infraestrutura de transporte.

\subsection{Potencialidades, limitações e recomendações.}

A proposta de análise para mobilidade urbana pode ser adaptada à realidade da cidade que for objeto de estudo. As variáveis e o nível hierárquico para cada Eixo de Análise podem ser propostos de acordo com o conhecimento específico dos problemas de cada município, de modo que importa conhecer a lógica presente no Procedimento de Análise Espacial para que se possa estabelecer novos arranjos em relação à árvore de avaliação, matriz de agregação e escalas de avaliação para cada variável. 
A principal vantagem deste Procedimento de Análise Espacial está na capacidade de representar a distribuição espacial de um conjunto de informações que são orientados por meio de uma Árvore de Avaliação e Matriz de Agregação e que permitem a combinação entre diversas variáveis para se obter o Mapa Potencial para Mobilidade Sustentável.

Em função disso, é possível expressar de modo mais direto e compreensível o resultado da interação entre "Forma" e "Transporte" na área em estudo. Conforme já colocado, o arranjo das árvores e matriz agregação podem ser alinhados conforme as expectativas e experiência do grupo que irá avaliar a área em questão. Outros grupos, valendo-se do mesmo método e área, podem considerar outros atributos mais importantes. Outra característica deste Procedimento de Análise Espacial é tornar mais objetivas as estratégias de entendimento da mobilidade urbana. Além disso, o resultado expresso por área de análise permite avaliações simultaneamente locais e globais, permitindo ações de ordem pontual em relação ao planejamento urbano e ao planejamento de transportes.

Os achados tornam válido o uso deste novo Procedimento de Análise Espacial em estudos de mobilidade urbana, ainda que seja em uma etapa de planejamento mais global para elaboração de Planos Diretores.

Além disso, cabe destacar que este tipo de procedimento encontra uma resposta positiva quando a sua aplicação acontece na fase inicial de planejamento urbano ou na criação de uma perspectiva futura em relação à área em análise para elaboração de Planos Diretores e de Transportes. Quando se criam as combinações entre as diversas variáveis, projeta-se uma perspectiva futura baseada nas experiências urbanas vivenciadas e teorias existentes sobre como se poderia alcançar um alto potencial para mobilidade sustentável.

Em relação as limitações referentes ao Procedimento de Análise Espacial pode-se pontuar os seguintes aspectos: i. o fato de haver uma impossibilidade de serem introduzidas, na análise, variáveis que não podem ser mapeadas. Esse aspecto inviabiliza a análise de variáveis que não podem ser espacializadas; ii. durante a fase de coleta de dados para avaliação de cada variável proposta nesta pesquisa, houve muita dificuldade em relação a disponibilização do dado por parte do órgão público responsável, ou seja, a aquisição do dado georreferenciado; este é um fator limitante da pesquisa, sem as informações necessárias tornase inviável a avaliação da variável proposta, além disso, algumas variáveis poderiam ser refinadas, se o dado fosse adequadamente disponibilizado, como o caso da variável "uso do solo urbano", entretanto a disponibilidade do dado não ocorreu, o que inviabilizou a desagregação da variável; iii. a fase de construção das árvores demanda tempo, conhecimento da área analisada e objetivos que se pretende alcançar em relação ao potencial de mobilidade 
sustentável; esses três aspectos estão muitos ligados ao perfil e experiência profissional para que se consiga chegar mais próximo da realidade; não que seja um limitante, mas é interessante que a construção das árvores de avaliação e matriz potencial contemple um grupo formado por vários profissionais que lidam com planejamento urbano e que conheçam a área em questão, pois desta forma existem chances maiores de se chegar a uma proposta de árvore e matriz adequada para o caso em questão.

A recomendação mais significativa a ser deixada por este trabalho consiste na aplicação deste procedimento em outras áreas urbanas, com configurações diferentes e nova proposta das árvores de avaliação e matriz de agregação. Uma vez aplicado, e no caso de ser validado nos demais municípios, o método poderia vir a se transformar em um modelo relevante para a, identificação de áreas com Potencial para Mobilidade Sustentável para o planejamento urbano e direcionamento de políticas de transporte. 


\section{BIBLIOGRAFIA}

ABDALA, I. M. de R. Aplicação do índice de mobilidade urbana sustentável (IMUS) em Goiânia. Dissertação de mestrado. PUC/GO. Programa de Pós-graduação de Desenvolvimento e Planejamento Territorial. Goiânia, 2013.

ACIOLY, C.; DAVIDSON, F. Densidade Urbana Um Instrumento de Planejamento e Gestão Urbana. 2. ed. Rio de Janeiro: Editora Mauad,1998.

ADAMS, J. Residential Structure of Midwestern Cities. In.: Annals of the Association of American Geographers 60(1): 37-62, 1970.

ALVES, S. R. Densidade Urbana - Compreensão e Estruturação do Espaço Urbano nos Territórios de Ocupação Dispersa. Dissertação de Mestrado. FAUTL: Lisboa, 2011.

ANTP - Associação Nacional de Transportes Públicos. Sistema de Informação da Mobilidade Urbana: Relatório Geral 2012. [Internet] Disponível em:< http://www.antp.org.br/_5dotSystem/userFiles/simob/relat\%C3\%B3rio\%20geral\%202011.pdf $>$ [Acessado em janeiro de 2013].

ARBURY, J. From Urban Sprawl to Compact City - An Analysis of Urban Growth Management in Auckland. MA Thesis. University of Aukland, 2005. [Internet] Disponível em: < http://portal.jarbury.net/thesis.pdf> [Acessado em janeiro de 2011].

ASCHER, F. Os novos princípios do urbanismo. Coleção RG bolso. São Paulo: Romano Guerra, 2010.

BARROS, A. P. B. G. Diz-me com quem andas que direi com quem estás: inserção do aspecto relacional na análise da mobilidade urbana para pedestre. Tese de doutorado. UnB, Faculdade de Tecnologia. Departamento de Engenharia Civil e Ambiental. Brasília, 2014.

BELLORIO, G. B. Adensamento e verticalização em Goiânia nos planos diretores (19682007). Dissertação de mestrado. PUC/GO. Departamento de Ciências Econômicas. Goiânia, 2013.

BERTAUD, A. e MALPEZZI, S. The Spatial Distribution of Population in 35 World Cities: The Role of Markets, Planning and Topography. Madison, Wisconsin, EUA. 1999. [Internet] Disponível em: <http://www.bus.wisc.edu/realestate/pdf/pdf/Bertaud\%20and\%20 Malpezzi\%20Part\%20One.pdf> [Acessado em janeiro de 2011].

BERTAUD, A.; MALPEZZI, S. The Spatial Distribution of Population in 48 World Cities: Implications for Economies in Transition. Madison, Wisconsin, EUA. 2003. [Internet] Disponível em: <http://www.bus.wisc.edu/realestate/pdf/pdf/Bertaud\%20and\%20Malpezzi\%20Part\%20One.p df $>$ [Acessado em janeiro de 2011]

BRASIL. Lei n. 10.257, de 10 de julho de 2001. Regulamenta os artigos 182 e 183 da Constituição Federal, estabelece diretrizes gerais da política urbana e dá outras providências. [Internet] Disponível em: 〈http://www.planalto.gov.br/ccivil_03/leis/leis_2001/110257.htm> [Acessado em outubro de 2012].

BRASIL. Lei n. 12.587, de 3 de janeiro de 2012. Institui as diretrizes da Política Nacional de Mobilidade Urbana. [Internet]

Disponível em: 
<http://www.planalto.gov.br/ccivil_03/_ato2011-2014/2012/lei/112587.htm> [Acessado em outubro de 2012].

BOARETO, R. A mobilidade urbana sustentável. In: Revista dos transportes públicos, $\mathrm{n}^{\circ} 100$. São Paulo: ANTP, 2003.

BURTON, E. The Potencial of the compact city for promoting social equity. In.: Willians, K.; Burton, E.; Jenks, M. (Ed.). Achieving sustainable urban Form (p. 19-29). Londres: E\&FN Sponn, 2000.

CAMPOS, V. B.; RAMOS, R. A. R. Proposta de Indicadores de Mobilidade Urbana Sustentável: Relacionado Transporte e Uso do Solo. In: Congresso Luso Brasileiro para o Planejamento Urbano, Regional, Integrado e Sustentável. Anais. São Carlos, São Paulo, 2005.

CAMPOS, V.B.G. Uma Visão da Mobilidade Urbana Sustentável. Programa de Engenharia de Transportes, 2007 IME [Internet] Disponível em: < http://aquarius.ime.eb.br/ webde2/prof/vania/pubs/(3)UMAVISAODAMOBILIDADE.pdf> [Acessado em de Fevereiro de 2012].

CANTALICE, A.S.C. Uma breve reflexão sobre forma urbana. ARCHITECTON - Revista de arquitetura e Urbanismo, V. 2, n. 2, 2012. [internet] Disponível em: < http://www.faculdadedamas.edu.br/revistas/index.php/arquitetura/article/view/223> [Acessado em de Fevereiro de 2014].

CERVERO, R. e KOCKELMAN, K. Travel Demand and 3 D’s: Density, Diversity, and Design. Transportation Research, 2 (3), p.199-219, Califórnia, 1997.

CE - COMISSÃO EUROPEIA. Cidades Europeias Sustentáveis - Relatório. 1996. [Internet] Disponível em: <http://ec.europa.eu/environment/urban/pdf/rport-pt.pdf> [Acessado em março de 2012].

COSTA, N. M. S. M. da. Mobilidade e Transporte em Áreas Urbanas. Tese de Doutorado Faculdade de Geografia de Lisboa. Universidade de Lisboa, 2007.

COSTA, M. da S. Um Índice de Mobilidade Urbana Sustentável. Tese de Doutorado. Escola de Engenharia de São Carlos. Universidade de São Paulo, 2008.

COUTINHO, Evaldo. O espaço da arquitetura. 2. ed. São Paulo: Perspectiva, 1998.

CRANE, R. The Impacts of Urban Form on Travel. 1999. [Internet] Disponível em: $<$ http://www.lincolninst.edu/pubs/62_The-Impacts-of-Urban-Form-on-Travel> [Acessado em março de 2011].

CUNHA, A. da; BOCHET, B. Métropolisation, forme urbaine et développement durable. In Cunha, A. da (Ed.), Développement durable et aménagement du territoire Presses Polytechiques et Universitaires Romandes, 83-100 Lausanne, 2003.

DIAS, M. L. A malha e o deslocamento: um estudo das relações entre configuração espacial e mobilidade urbana em Goiânia. Dissertação de Mestrado. PPGFAU. UnB. 2014.

DPP. As formas e o Funcionamento das Cidades e os Desafios da Sustentabilidade. 2011 [Internet] Disponível em: < http://www.dpp.pt/pt/publicacoes/estudos-edocumentos/Paginas/default.aspx > [Acessado em Fevereiro de 2012]. 
DUARTE, F.; SÁNCHEZ, K.; LIBARDI, R. Introdução à Mobilidade Urbana. 1 ed. Curitiba: Juruà, 2008.

ECHENIQUE, M. Cities for the new millennium. Washington, DC: Island, 2001.

EEA - EUROPEAN ENVIRONMENT AGENCY. Urban Sprawl in Europe: The ignored challenge. 2006. [Internet] Disponível em: <http://www.eea.europa.eu/> [Acessado em Fevereiro de 2012].

EWING R.; HALIYUR, P.; PAGE, G.W. Getting Around a Traditional City, a Suburban Planned unit Development and everything in between. In.: Transport Research Board (p. 53-62). 1994

EWING, R. Is Los Angeles- Style Sprawl Desirable? In.: Journal of the American Planning Association 63(1): 107-124, 1997.

FARIA, S. C. Guia de Elaboração e Revisão do Plano Diretor Municipal com Base em análise do Risco Ecológico. Ministério do Meio Ambiente. 2006.

FERNANDES, K.D.L.M.; MAIA, M.L.A.; FERRAZ, C. Forma Urbana e deslocamentos pendulares: uma análise dos bairros de casa caiada e jardim Brasil em Olinda- PE. 2008. [Internet] Disponível em: <http://www.anpet.org.br/ssat/interface/content/autor/trabalhos/publicacao/2008/248_AC.pdf $>$ [Acessado em julho de 2011].

FERNANDES, K.D.L.M. A influência da forma urbana e da legislação urbanística na mobilidade urbana: O caso do Plano Diretor de Olinda. Dissertação de Mestrado Universidade Federal de Pernambuco - Faculdade de Engenharia Civil, 2008.

FERREIRA, L.C.G. Uma reflexão sobre a expansão e mobilidade em Goiânia: uma análise do plano diretor de Goiânia - GO. In: OBSERVATORIUM: Revista Eletrônica de Geografia, v.5, n.15, p. 62-86, dez. 2013. [Internet] Disponível em: < http://www.observatorium.ig.ufu.br/pdfs/5edicao/n15/04.pdf > [Acessado em dezembro de 2014].

FRANK L. D.; PIVO, G. Impacts of mixed use and density on utilization of three modes of travel: single-occupant vehicle, transit, and walking. 2005. [Internet] Disponível em: < http://www.reconnectingamerica.org/assets/Uploads/Frank-and-Pivo.pdf > [Acessado em Fevereiro de 2012].

GARCIA, D., e RIERA P. Expansion versus density in Barcelona: A valuation exercise. Urban Studies 40 (10): 1925-36, 2003.

GAUTHIER, P.; GILLILAND, J. Mapping urban morphology: a classification scheme for interpreting contributions to the study of urban form. In.: Urban Morphology. v. 10, n. 1, p. 41-50, 2006.

GENTIL, C. D. A.; BEZERRA, M. C. L.; MEDEIROS, V. A. S. de. As faces da mobilidade urbana: configuração, uso do solo e políticas públicas em Goiânia (Brasil). In: 6 Congresso Luso-brasileiro para o planejamento urbano, integrado e sustentável - PLURIS., Lisboa, 2014.

GOIÂNIA, Prefeitura Municipal - Lei Complementar $\mathbf{N}^{\circ}$ 171, de 29 de maio de 2007 - Plano Diretor do Município de Goiânia. Coletânea Legislação e Regulamentos do Plano Diretor; 
Edição atualizada, novembro/2009 - Prefeitura de Goiânia, SEPLAM- Secretaria Municipal de Planejamento e Urbanismo.

GOMES, J. C. F. A Mobilidade e a Teoria da Cidade Compacta - Caso Estudo: A cidade de Lisboa. Dissertação de Mestrado - Universidade Técnica de Lisboa, Lisboa, 2009.

GOMIDE, A. de Á. Mobilidade Urbana, Iniquiidade e Políticas Sociais. 2006. [Internet] Disponível em: <http://www.ipea.gov.br/sites/000/2/publicacoes/bpsociais/bps_12/ensaio5_alexandre.pdf>[A cessado em agosto de 2011]

GUDMUNDSSON, H. Sustainable transport and performance indicators. In.: Hester, R.E. e Harrison, R.M. (Eds). Issues in environmental science and technology. n.20, p. 35-63, 2004. [Internet] Disponível em: <http://pubs.rsc.org/en/content/chapter/bk9780854042951-

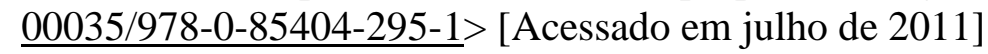

HANDY, S. Regional versus local Acessibility: Variation in Suburban form and the Implications fo Nowork Travel. Unpublished PhD Dissertation. University of California at Berkeley, 1992.

HILLIER, B.; HANSON, J. The social logic of space. Cambridge: Cambridge University Press, 1984.

HOLANDA, F. de; KOHLSDORF, M.E.; FARRET, R.L.; CORDEIRO, S.H.C. Forma urbana: que maneiras de compreensão e representação? 2000. Disponível em: < repositorio.unb.br/bitstream/10482/12151/.../ARTIGO_FormaUrbana.pdf> [Acessado em janeiro de 2014]

HOLANDA, F. de. O Espaço de Exceção. Brasília: Editora Universidade de Brasília, 2002.

HOLANDA, F. de. Arquitetura e Urbanidade. São Paulo: PRO editores, 2003.

HOLANDA, F. de; KOHLSDORF, G. Arquitetura como situação relacional. 2004. Disponível em: < https://dspace.ist.utl.pt/bitstream/2295/1010800/1/holandaekohlsdorf.pdf> [Acessado em maio de 2013]

HOLANDA, F. de. Brasília - Cidade Moderna, Cidade Eterna. Brasília: FAU UnB, 2010.

HOLANDO, F. de.; 10 Mandamentos da Arquitetura. Editora FRBH. Brasília, 2013.

IPEA - Instituto de Pesquisas Aplicadas. SIPS: Sistema de Indicadores de Percepção Social Mobilidade Urbana. 2011. [Internet] Disponível em: <http://www.ipea.gov.br/portal/images/stories/PDFs/SIPS/110124_sips_mobilidade.pdf> [Acessado em julho de 2012]

JABAREEN, Y.R. Sustainable Urban Forms: Their Typologies, Models, and Concepts. Journal of Planning Education and Research, 2006. [Internet] Disponível em: <http://jpe.sagepub.com/cgi/content/abstract/26/1/38> [Acessado em Março de 2012]

JENKS, M.; BURGESS, R. Compact Cities: Sustainable Urban Forms For Developing Countries. Spon Press. London and New York, 2000.

JENKS, M.; BURTON, E.; WILLIAMS K. (Ed.). The compact city: A sustainable urban form? London: Chapman and Hall, 1996. 
JACOBS, J. Morte e Vida de Grandes Cidades. 2. Ed. São Paulo: Editora WMF, Martins Fontes, 2009.

KNEIB, E. Subcentros urbanos: contribuição conceitual e metodológica à sua definição e identificação para o planejamento de transportes. Tese de doutorado. UnB, Faculdade de Tecnologia. Departamento de Engenharia Civil e Ambiental. Brasília, 2008.

KNEIB, E. Dossiê mobilidade: Mobilidade urbana e qualidade de vida: do panorama geral ao caso de Goiânia. Revista UFG, Goiânia, n¹2, ano XIV. 2012.

KNEIB, E. Identificação de centralidade urbanas: aprimoramento de metodologia e aplicação em Goiânia, Brasil. [pen drive], In: $6^{\circ}$ Congresso Luso-brasileiro para o Planejamento Urbano, Regional, Integrado e Sustentável - PLURIS, Lisboa, 2014.

LAMAS, J. .1 R.G. Morfologia Urbana e Desenho da Cidade. 2ed. Lisboa: Fundação Calouste Gulbenkian - Fundação para a Ciência e Tecnologia, 1999.

LEITE, C.; AWAD, J. di C.M. Cidades Sustentáveis, Cidades Inteligentes: desenvolvimento sustentável num planeta urbano. Porto Alegre: bookman, 2012.

LITMAN, T. Land Use Impacts on Transport - How Land Use Factors Affect Travel Behavior. 2012. [Internet] Disponível em: 〈http://www.vtpi.org/landtravel.pdf >. [Acessado em agosto de 2012]

MACEDO, A. C. A carta do novo urbanismo norteamericano. Integração (São Paulo), v. 48, p. 11-21, 2007. Disponível em: 〈https://uspdigital.usp.br〉. Acesso em: 03 out. 2013.

MANCINI, G. A. Avaliação dos custos da urbanização dispersa do Distrito Federal. Dissertação de Mestrado - UnB, Brasília, 2008.

MACHADO, L. Índice de Mobilidade Sustentável para Avaliar a Qualidade de Vida Urbana. Estudo de Caso: Região Metropolitana de Porto Alegre - RMPA. Dissertação de Mestrado - UFRGS, Porto Alegre, 2010.

MAGALHÃES, M. T.; YAMASHITA, Y. Definição de Mobilidade: Uma abordagem crítica na delimitação do conceito. [2006?]

MARÍN, A.G., JARAMILLO, P. Urban rapid transit network design: accelerated Benders decomposition. Annals of Operations Research, 136, p.35-53,2009.

MCHARG, I. Design With Nature. Doubleday Natural History Press. New York, 1971.

MEDEIROS, V. A. S. de. Urbis Brasiliae ou sobre cidades do Brasil: inserindo assentamentos urbanos do país em investigações configuracionais comparativas. Tese de Doutorado. PPG/FAU/UnB. Brasília, 2006.

MEDEIROS, V. A. S. de. Urbis Brasiliae: o labirinto das cidades brasileiras. Brasília: Editora UnB,2013.

MEDEIROS, V. A. S. de. BARROS, A. P. B. G. A forma urbana e o deslocamento nas cidades: uma estratégia para a interpretação da mobilidade em 22 capitais brasileiras. In: CLME 2011 - 6o. Congresso Luso-Moçambicano de Engenharia, 2011, Maputo Moçambique. Anais do CLME 2011 - 6o. Congresso Luso-Moçambicano de Engenharia, v. 1. p. 1-21, 2011. 
MINISTÉRIO DAS CIDADES. Caderno MCidades: Política Nacional de Mobilidade Urbana Sustentável. Ministério das Cidades, Brasília, 2005.

MINISTÉRIO DAS CIDADES. Gestão Integrada da Mobilidade Urbana. Módulo 2: Cidade, Cidadão e Mobilidade Urbana Sustentável. Ministério das Cidades, Brasília, 2006.

MINISTÉRIO DAS CIDADES. PlanMob: Construindo a cidade sustentável. Caderno de referência para elaboração do plano de mobilidade urbana. 2007. [Internet] Disponível em: <http://www.cidades.gov.br/media/livroPlanoMobilidade05092007.pdf> [Acessado em janeiro de 2011].

MORAES, L. M. A segregação planejada: Goiânia, Brasília e Palmas. Editora da UCG. Goiânia, 2006.

MOREIRA, I. Manual de Avaliação de Impactos Ambientais. Curitiba, 1992.

MOYSÉS, A. Contradições de uma cidade planejada no Planalto Central Brasileiro: segregação sócio-territorial em Goiânia. Tese de Doutorado. Ciências Ambientais. Universidade Católica de São Paulo. São Paulo, 2001.

MOYSÉS. A. Goiânia metrópole não planejada. Editora da UCG. Goiânia, 2004.

NEUMAN, M. The Compact City Fallacy. Journal of Planning Education and Research. Volume 25, $\mathrm{n}^{\circ} 1,2005$, pp. 11-26. 2005 [Internet] Disponível em: $<$ http://jpe.sagepub.com/content/25/1/11> [Acessado em julho de 2011].

NEWMAN, P. W. G. e KENWORTHY, J. R. Gasoline Consumption in Cities: a Comparison of US Cities with a Global Survey. Journal of the American Planning Association, v.55, p.24-37,1989.

NEWTON, P. Urban Form and Environmental Performance. In.: WiLliams, K.; BURTON, E.; JENKS, M., (Ed.) Achieving Sustainable Urban Form (p. 46-53). Londres, E\&FN Spon, 2000.

NTU - ASSOCIAÇÃO NACIONAL DAS EMPRESAS DE TRANSPORTES URBANOS. Faixas Exclusivas de Ônibus Urbanos - Experiências de Sucesso. Brasília, DF. 2013.

OECD - ORGANIZATION FOR ECONOMIC COOPERATION AND DEVELOPMENT. OECD Guidelines towards Environmentally Sustainable Transport. Paris, OECD Publications. 2002.

OJIMA, R. Análise comparativa da dispersão urbana nas aglomerações urbanas brasileiras: elementos teóricos e metodológicos para o planejamento urbano e ambiental. Tese de doutorado. Universidade estadual de Campinas. Instituto de filosofia e ciências humanas. 2007.

OLIVEIRA, A. F. de. A Reprodução do Espaço Urbano de Goiânia: uma cidade para o capital. Observatório das Metrópoles, Rio de Janeiro, v. 31, p. 01-25, 2004.

OWENS, S. Energy, Environmental Sustainability and Land-Use Planning. In.: BREHENY, M. (Ed.) Sustainable Development and Urban Form (p. 79-105). Londres: Pion, 1992.

PAIVA, C. Acessibilidade: Alguns Conceitos e Indicadores. 2010 [Internet] Disponível em: < http://www.sinaldetransito.com.br/artigos/acessibilidade_sistema_viario.pdf> [Acessado em fevereiro de 2013]. 
PANERAI, P. Análise Urbana. Brasília: Editora Universidade de Brasília, 2006.

PASSOS, T. N. F. dos; Efeitos da ocupação urbana na sustentabilidade ambiental do Córrego Guará - DF. Dissertação de mestrado. Programa de Pós-graduação em gestão ambiental. Universidade Católica de Brasília. Brasília, 2007.

PIRES, C. de C. Potencialidades Cicloviárias no Plano Piloto. Dissertação de Mestrado. PPG/FAU/UnB. Brsília, 2008.

POUYAnne, G. Land Use Mix and Daily Mobility: The Case of Bordeaux. 2005. [Internet] Disponível em: <http://econpapers.repec.org/RAS/ppo101.htm> [Acessado em fevereiro de 2012]

REGO, R. L.; MENEGUETTI, K.S. A Respeito de Morfologia Urbana. Tópicos Básicos para Estudos da Forma da Cidade. 2011. [Internet] Disponível em: <http://econpapers.repec.org/RAS/ppo101.htm> [Acessado em outubro de 2012]

RIBAS, O. Critério e diretrizes de planejamento e desenho urbano para Asa Norte (área F), do plano urbanístico "Brasília Revisitada" visando a minimização dos impactos sobre o meio ambiente natural. Dissertação de Mestrado. PPGFAU. UnB. Brasília, 1988.

RIBAS, O. A sustentabilidade das cidades: os instrumentos da gestão urbana e a construção da qualidade ambiental. Tese de Doutorado. Centro de Desenvolvimento Sustentável. UnB. Brasília, 2003.

RIBEIRO, R. J. da C. Índice Composto de Qualidade de Vida Urbana: Aspectos de Configuração Espacial, Socioeconômicos e Ambientais Urbanos. Tese de Doutorado. PPG/FAU/UnB, 2008.

RICHARDSON, H. W.; BAE, C. C. e BAXAMUSA, M. Compact Cities in Developing Countries: Assessment and Implications. In.: JENKS M.; BURGESS R. (Ed.) Compact Cities: Sustainable Urban Forms for Developing Countries. London and New York: Spon Press, 2001, pp. 25-36.

ROGERS, R.; GUMUCHDJIAM, P. Cidades para um pequeno planeta. 1ed. Barcelona: Ed. Gustavo Gilli, 2001.

ROMERO, M. A. B. Estratégias bioclimáticas de reabilitação ambiental adaptadas ao projeto. In: Reabilitação ambiental sustentável arquitetônica e urbanística. Brasília, FAU/UnB, 2009.

RUEDA, S. Modelos de Ordenacion Del Território Más Sostenibles, 2002. [Internet] Disponível em:< http://habitat.aq.upm.es/boletin/n32/asrue.html\#3> [Acessado em julho de 2012].

SABOYA, R. Segregação espacial urbana. 2009. [Internet] Disponível em:<http://urbanidades.arq.br/2009/05/segregacao-espacial-urbana/> [Acessado em julho de 2012].

SEABRA, L. O. Índice para Gestão Estratégica da Mobilidade Urbana Sustentável. Tese de doutorado. Faculdade de Tecnologia. UnB, ENC/FT/UnB. 2013

SEPE, P. M.; GOMES, S. Indicadores Ambientais e Gestão Urbana: desafios para contrução da sustentabilidade na cidade de São Paulo. São Paulo: Secretaria Municipal do Cerde e do Meio Ambiente:Centro de Estudos da Metrópole, 2008. 
SHAFER, A. The global demand for motorized mobility. Transportation Research Part A. v. 32, n.6, p.455-477, 1998.

SHAFER, A., VICTOR, D.G. The future mobility of the world population. Transportation Research Part A. n.34, p.171-205, 2000.

SILVA, G. P. Forma Urbana e Sustentabilidade: Algumas notas sobre o modelo de cidade compacta. Departamento de Prospectiva e Planejamento e Relações Internacionais. 2008. [Internet] Disponível em: <http://www.dpp.pt/Lists/Pesquisa\%20Avanada/Attachments/1401/Forma_Urbana.pdf> [Acessado em julho de 2011].

SILVA, G. J. A. da, e ROMERO, M. A. B. O urbanismo Sustentável no Brasil: A Revisão de Conceitos Urbanos Para o Século XXI (Parte 02), 2011. [Internet] Disponível em: <http://www.vitruvius.com.br/revistas/read/arquitextos/11.129/3499> [Acessado em julho de 2011]

SILVA, G. J. A. Cidades Sustentáveis: Uma Nova Condição Urbana. Tese de Doutorado FAU/UnB. Brasília, 2011.

VASCONCELlOS, E. de A. A Cidade, o Transporte e o Trânsito. São Paulo: Polilivros, 2005.

VILLAÇA, F. Espaço Intra-urbano no Brasil. São Paulo: Estúdio Nobel - Fapesp: Lincoln Institute, 2001.

TAAFFE, E. J.; GAUTHIER, H. L.; O'KELLY, M. E. Geography of Transportation. New Jersey, Prentice-Hall Inc, 1996.

TULLOCH, J. Novo urbanismo: cidades para pessoas em vez de carros. [Internet] Disponível em: < http://www.mobilize.org.br/noticias/5863/novo-urbanismo-cidades-para-pessoas-emvez-de carros.html> [Acessado em: Janeiro, 2014].

VIANA, J. L. R.; ARRAIS, T. P. A. Espacialização e análise dos recursos provenientes de receitas próprias e convênios com o governo federal para os municípios da Região Metropolitana de Goiânia, entre 2008 e 2010. In: 63ª Reunião Anual da SBPC, 2011, Goiânia. VIII Congresso de Pesquisa, Ensino e Extensão - Conpeex, 2011.

WU, J.H., FLORIAN, M., MARCOTTE, P. Transit equilibrium assignment: a model and solution algorithms. Transportation Science. v.28, n.3, August, p.193-203, 1994. 


\section{ANEXO A: Conjunto de indicadores sugeridos por Costa (2011).}

\begin{tabular}{|c|c|c|}
\hline CATEGORIA & TEMA & INDICADOR \\
\hline \multirow{4}{*}{ 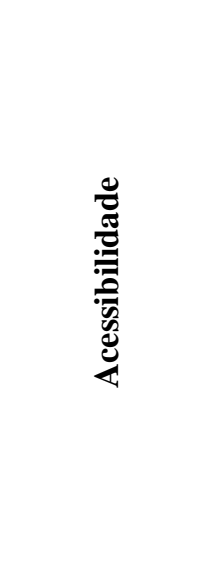 } & Acessibilidade ao sistema de transporte & $\begin{array}{l}\text { Acessibilidade ao transporte público. } \\
\text { Transporte público para pessoas com } \\
\text { necessidades específicas. } \\
\text { Despesas com transporte. }\end{array}$ \\
\hline & Acessibilidade universal & $\begin{array}{l}\text { Travessia adaptada a pessoas com necessidades } \\
\text { especiais. } \\
\text { Acessibilidade a espaços abertos. } \\
\text { Vagas de estacionamento para pessoas com } \\
\text { necessidades especiais. } \\
\text { Acessibilidade a edifícios públicos. } \\
\text { Acessibilidade aos serviços essenciais. }\end{array}$ \\
\hline & Barreiras físicas & Fragmentação urbana. \\
\hline & Legislação para pessoas com & Ações para acessibilidade universal. \\
\hline \multirow{2}{*}{ 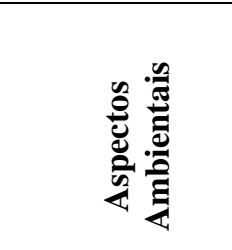 } & $\begin{array}{l}\text { Controle dos impactos ambientais no } \\
\text { meio ambiente }\end{array}$ & $\begin{array}{l}\text { Emissões de CO. } \\
\text { Emissões de } \mathrm{CO} 2 . \\
\text { População exposta ao ruído de tráfego. } \\
\text { Estudos de impacto ambiental. }\end{array}$ \\
\hline & Recursos naturais & $\begin{array}{l}\text { Consumo de combustível. } \\
\text { Uso de energia limpa e combustíveis alternativos. }\end{array}$ \\
\hline \multirow{5}{*}{ 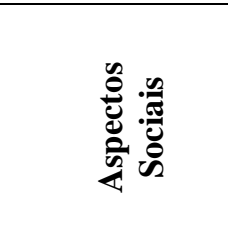 } & Apoio ao cidadão & Informações disponíveis ao cidadão. \\
\hline & Inclusão social & Equidade vertical. \\
\hline & Educação e cidadania & Educação para o desenvolvimento sustentável. \\
\hline & Participação popular & Participação na tomada de decisão. \\
\hline & Qualidade de vida & Qualidade de vida. \\
\hline \multirow{3}{*}{ 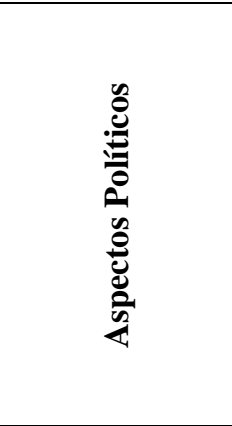 } & Integração de ações políticas & $\begin{array}{l}\text { Integração entre níveis de governo. } \\
\text { Parcerias público privadas. }\end{array}$ \\
\hline & Captação e gerenciamento de recursos & $\begin{array}{l}\text { Captação de recursos. } \\
\text { Investimento em sistema de transportes. } \\
\text { Distribuição de recursos (público x privado). } \\
\text { Distribuição dos recursos (motorizados x não- } \\
\text { motorizados). } \\
\text { Política de mobilidade urbana. }\end{array}$ \\
\hline & Política de mobilidade urbana & Política de mobilidade urbana. \\
\hline \multirow[t]{2}{*}{$\underset{\Xi}{E}$} & $\begin{array}{c}\text { Provisão e manutenção da infraestrutura } \\
\text { de transportes }\end{array}$ & $\begin{array}{l}\text { Densidade da rede viária. } \\
\text { Vias pavimentadas. } \\
\text { Despesas com manutenção da infraestrutura de } \\
\text { transportes. }\end{array}$ \\
\hline & Distribuição da infraestrutura de & Vias de transporte coletivo. \\
\hline \multirow{3}{*}{ 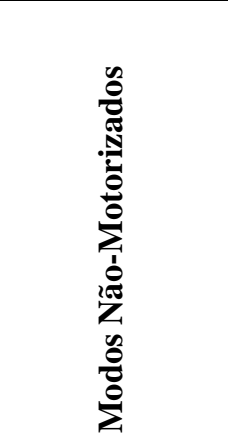 } & Transporte cicloviário & $\begin{array}{l}\text { Extensão e conectividade de ciclovias. } \\
\text { Frota de bicicletas. } \\
\text { Estacionamento de bicicletas. }\end{array}$ \\
\hline & Deslocamentos a pé & $\begin{array}{l}\text { Vias para pedestre. } \\
\text { Vias com calçadas. }\end{array}$ \\
\hline & Redução de viagens & $\begin{array}{l}\text { Distância de viagem. } \\
\text { Tempo de viagem. } \\
\text { Número de viagens. } \\
\text { Ações para redução do tráfego motorizado. }\end{array}$ \\
\hline
\end{tabular}




\begin{tabular}{|c|c|c|}
\hline CATEGORIA & TEMA & INDICADOR \\
\hline \multirow{8}{*}{ 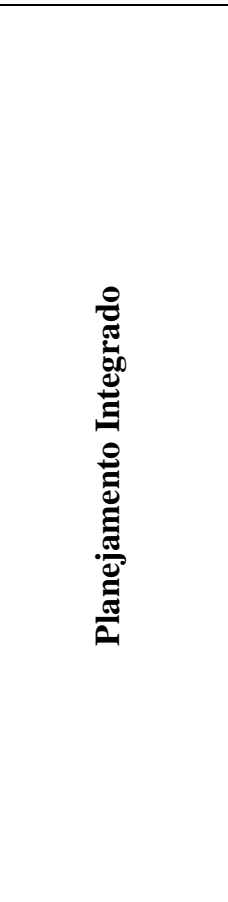 } & Capacitação de gestores & $\begin{array}{l}\text { Nível de formação de técnico e gestores. } \\
\text { Capacitação de técnicos e gestores. }\end{array}$ \\
\hline & Áreas centrais e de interesse histórico & Vitalidade do centro. \\
\hline & Integração regional & $\begin{array}{l}\text { Consórcios intermunicipais. } \\
\text { Transparência e responsabilidade. }\end{array}$ \\
\hline & Transparência do processo de planejamento & Transparência e responsabilidade. \\
\hline & $\begin{array}{l}\begin{array}{l}\text { Planejamento e controle do uso e ocupação do } \\
\text { solo }\end{array}\end{array}$ & $\begin{array}{l}\text { Vazios urbanos. } \\
\text { Crescimento urbano. } \\
\text { Densidade populacional. } \\
\text { Índice de uso misto. } \\
\text { Ocupações irregulares. }\end{array}$ \\
\hline & Planejamento estratégico e integrado & $\begin{array}{l}\text { Planejamento urbano, ambiental e de transporte } \\
\text { integrado. } \\
\text { Efetivação e continuidade das ações. }\end{array}$ \\
\hline & $\begin{array}{l}\text { Planejamento da infraestrutura urbana e } \\
\text { equipamentos urbanos }\end{array}$ & $\begin{array}{l}\text { Parques e áreas verdes. } \\
\text { Equipamentos urbanos (escolas). } \\
\text { Equipamentos urbanos (hospitais). }\end{array}$ \\
\hline & Plano diretor e legislação urbanística & $\begin{array}{l}\text { Plano diretor. } \\
\text { Legislação urbanística. } \\
\text { Cumprimento da legislação urbanística. }\end{array}$ \\
\hline \multirow{5}{*}{ 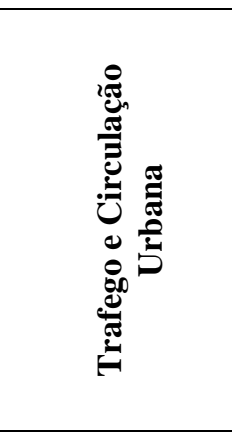 } & Acidentes de trânsito & $\begin{array}{l}\text { Acidentes de trânsito. } \\
\text { Acidentes com pedestres e ciclistas. } \\
\text { Prevenção de acidentes. }\end{array}$ \\
\hline & Educação para o trânsito & Educação para o trânsito. \\
\hline & Fluidez e circulação & $\begin{array}{l}\text { Congestionamento. } \\
\text { Velocidade média de tráfego. }\end{array}$ \\
\hline & Operação e fiscalização de trânsito & Violação das leis de trânsito. \\
\hline & Transporte individual & $\begin{array}{l}\text { Índice de motorização. } \\
\text { Taxa de ocupação de veículos. }\end{array}$ \\
\hline \multirow{5}{*}{ 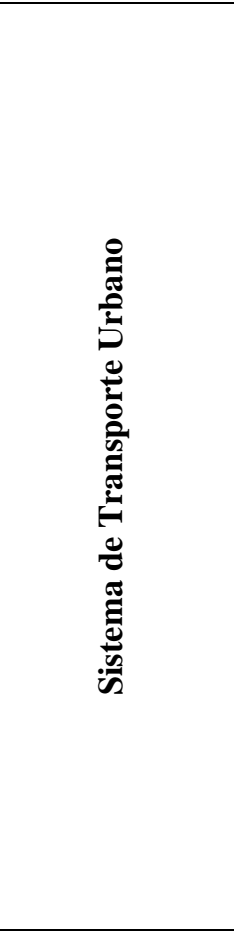 } & $\begin{array}{l}\text { Disponibilidade e qualidade do transporte } \\
\text { público }\end{array}$ & $\begin{array}{l}\text { Extensão da rede de transporte público. } \\
\text { Frequência de atendimento do transporte público. } \\
\text { Pontualidade. } \\
\text { Velocidade média do transporte público. } \\
\text { Idade média da frota de transporte público. } \\
\text { Índice de passageiro por quilômetro. } \\
\text { Passageiros transportados anualmente. } \\
\text { Satisfação do usuário com o serviço de transporte } \\
\text { público. }\end{array}$ \\
\hline & Diversificação modal & $\begin{array}{l}\text { Diversidade de modos de transporte. } \\
\text { Transporte público x transporte privado. } \\
\text { Modos motorizados x modos não-motorizados. }\end{array}$ \\
\hline & Regulação e fiscalização do transporte público & $\begin{array}{l}\text { Contratos e licitações. } \\
\text { Transporte clandestino. }\end{array}$ \\
\hline & Integração do transporte público & $\begin{array}{l}\text { Terminais intermodais. } \\
\text { Integração do transporte público. }\end{array}$ \\
\hline & Política tarifária & $\begin{array}{l}\text { Descontos e gratuidade. } \\
\text { Tarifas de transporte. } \\
\text { Subsídios públicos. }\end{array}$ \\
\hline
\end{tabular}

